U norden

Marine invasive species in the Arctic

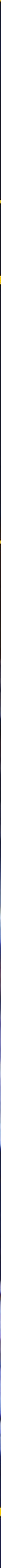



2 norden 



\section{Marine invasive species in the Arctic}

Edited by:

Linda Fernandez, Brooks A. Kaiser and Niels Vestergaard 
Marine invasive species in the Arctic

Edited by: Linda Fernandez, Brooks A. Kaiser and Niels Vestergaard

ISBN 978-92-893-2820-3

ISBN 978-92-893-2821-0 (EPUB)

http://dx.doi.org/10.6027/TN2014-547

TemaNord 2014:547

ISSN 0908-6692

(C) Nordic Council of Ministers 2014

Layout: Hanne Lebech

Cover photo: Signelements

This publication has been published with financial support by the Nordic Council of Ministers. However, the contents of this publication do not necessarily reflect the views, policies or recommendations of the Nordic Council of Ministers.

www.norden.org/en/publications

Nordic co-operation

Nordic co-operation is one of the world's most extensive forms of regional collaboration, involving Denmark, Finland, Iceland, Norway, Sweden, and the Faroe Islands, Greenland, and Åland.

Nordic co-operation has firm traditions in politics, the economy, and culture. It plays an important role in European and international collaboration, and aims at creating a strong Nordic community in a strong Europe.

Nordic co-operation seeks to safeguard Nordic and regional interests and principles in the global community. Common Nordic values help the region solidify its position as one of the world's most innovative and competitive.

\section{Nordic Council of Ministers}

Ved Stranden 18

DK-1061 Copenhagen K

Phone (+45) 33960200

www.norden.org 


\section{Content}

Introduction

Linda Fernandez, Brooks Kaiser and Niels Vestergaard ........................................... 9

Section 1: What's at Stake: Setting the Stage................................................................... 13

1. Meeting the Challenge of a Changing Arctic

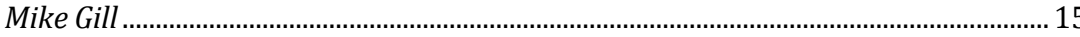

1.1 Arctic Marine Biodiversity and Invasive Alien Species: What's at

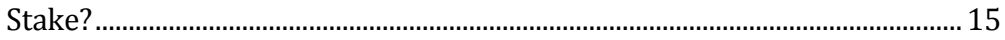

1.2 Meeting the Challenge of a Changing Arctic.................................................... 20

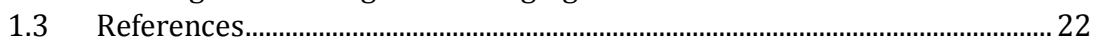

2. Marine invasive species: Issues and challenges in resource governance and monitoring of societal impacts

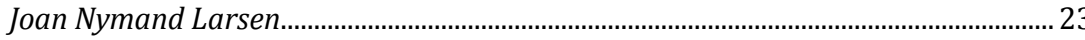

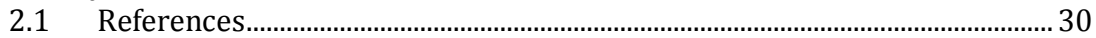

Section 2: Shipping and Invasive Species in the Arctic..................................................... 33

3. Melting Sea Ice, Accelerated Shipping, and Arctic Invasions

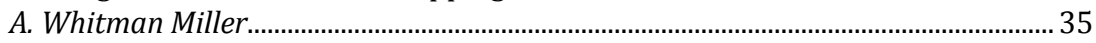

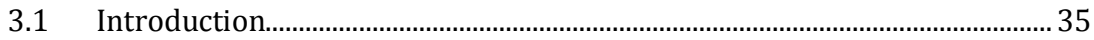

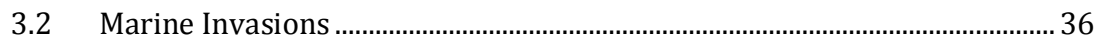

3.3 Commercial Ships as Vectors ………….............................................................. 38

3.4 Arctic and Trans-Arctic shipping ................................................................. 40

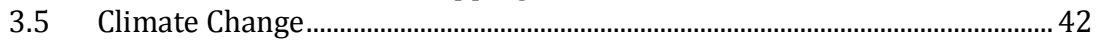

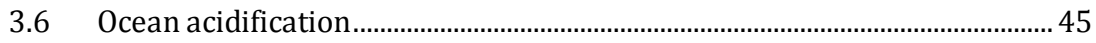

3.7 Drivers and Determinants of Invasion Opportunity and their

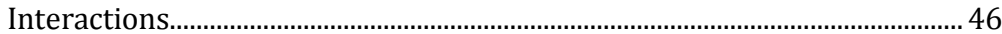

3.8 Ship Vector Regulations ........................................................................................ 48

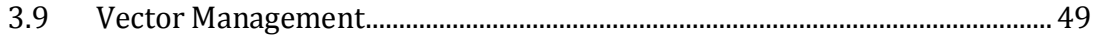

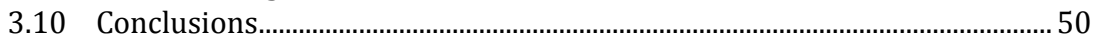

3.11 Acknowledgements............................................................................................ 51

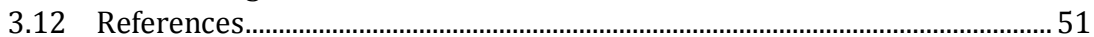

4. Management challenges and opportunities for marine biosecurity in the Arctic

Oliver Floerl .............................................................................................................. 57

4.1 Biosecurity management and its importance ................................................ 57

4.2 A simple framework for effective biosecurity management...........................58

4.3 Challenges and opportunities for the Arctic region...........................................63 63

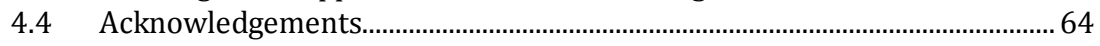

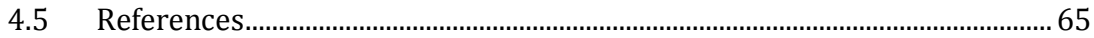


Section 3: Current Invasive Species Problems in the Arctic: Case Studies.

5. The red king crab (Paralithodes camschaticus) in the Barents Sea

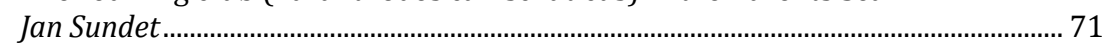

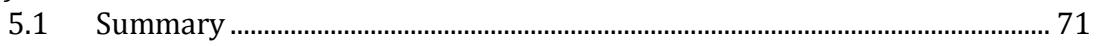

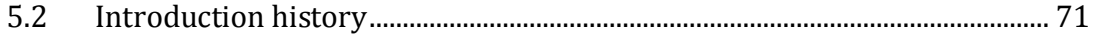

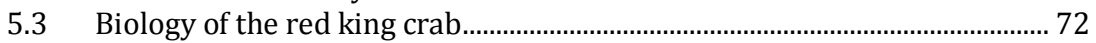

5.4 Impact on ecosystem and fisheries............................................................... 76

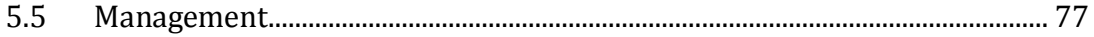

5.6 The snow crab (Chionoecetes opilio) in the Barents Sea: Summary.............. 78

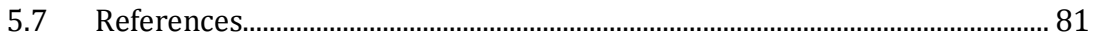

6. Invasive Species: Case studies from Iceland

Gudrun Thorarinsdottir, Karl Gunnarsson and Ó. Sindri Gíslason................................ 83

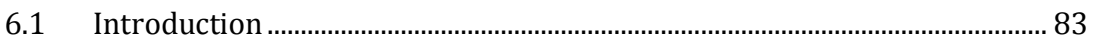

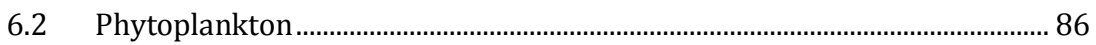

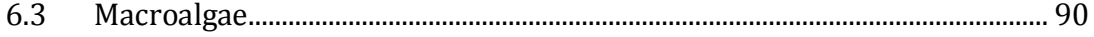

6.4 Figure 7: Codium fragile ................................................................................... 93

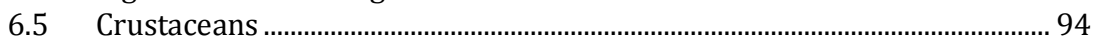

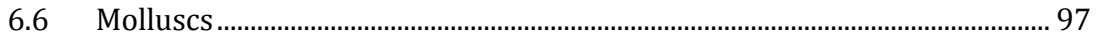

6.7 Cerastoderma edule (Linnaeus, 1758) ......................................................... 98

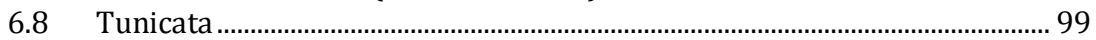

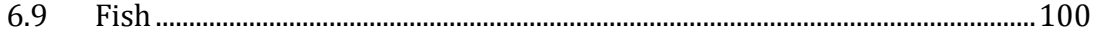

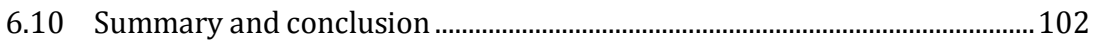

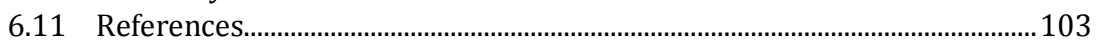

Section 4: Policy-oriented Invasive Species Case Studies ...............................................111

7. Optimizing policies to combat aquatic invasive species

Jarkko K. Niemi, Kari Hyytiäinen, Maiju Lehtiniemi and Kimmo Tikka ....................113

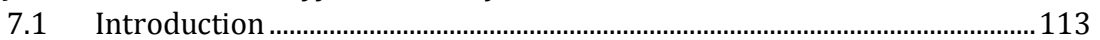

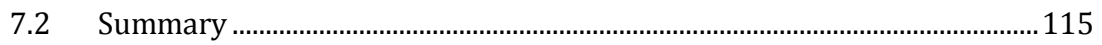

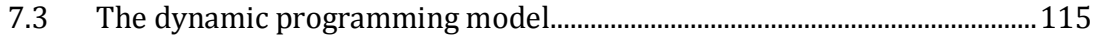

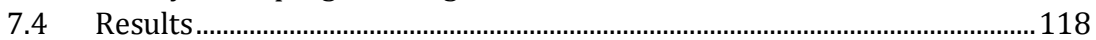

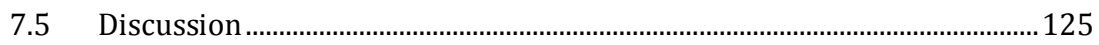

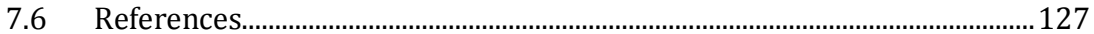

8. Adaptive harvest strategies in the case of invasive species- induced mortality

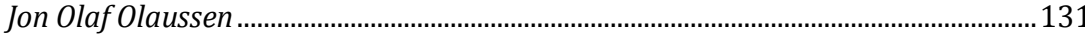

8.1 Abstract...................................................................................................... 131

8.2 Introduction .............................................................................................. 131

8.3 Population model and welfare function ...........................................................134

8.4 A Numerical illustration.................................................................................. 136

8.5 Concluding remarks .................................................................................. 142

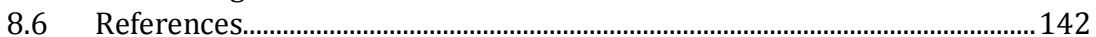


Section 5: Invasive Species Management and Policy

9. The interaction of natural and social systems: how International Relations theory can inform research on Arctic marine invasive species

Rasmus Gjedssø Bertelsen . .147

9.1 Introduction: Natural and social systems, International Relations theory and invasive species in the Arctic.

9.2 Doing International Relations Arctic research..............................................148

9.3 Linking natural and social systems .............................................................150

9.4 Theoretically informed International Relations research on invasive species in the Arctic ...........................................................................151

9.5 Realism: Power (Transition), China and the Arctic ......................................152

9.6 Liberalism: the importance of other actors and their interests...................154

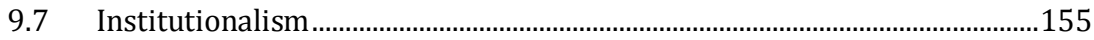

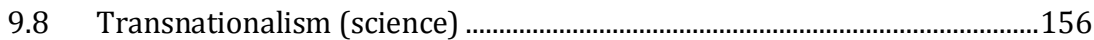

9.9 Transnationalism (indigenous peoples) ......................................................157

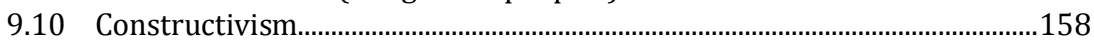

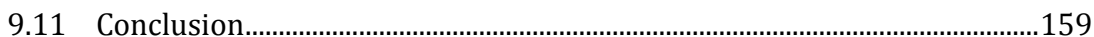

9.12 References......................................................................................................160

10. Bioeconomic Strategies to Address Potential Marine Invasive Species in the Arctic

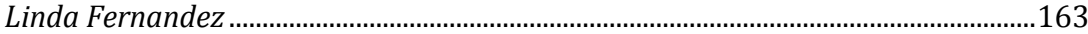

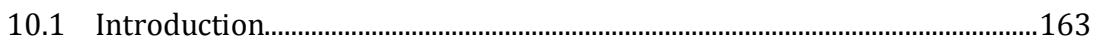

10.2 Four Analyses with Lessons for the Arctic ....................................................164

10.3 Analysis 1: International Maritime Shipping and Strategies between Trading Countries ...............................................................................165

10.4 Analysis 2: Port and Ship Incentives for both Ballast Water and

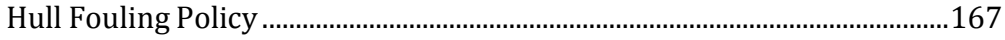

10.5 Analysis 3: Recreational Boats.........................................................................169

10.6 Analysis 4: Coastal Waters, Aquaculture and Other Leasers ........................171

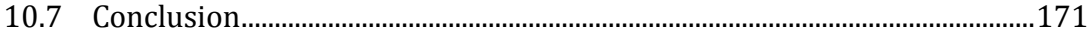

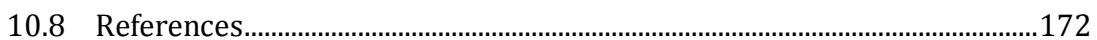

11. Invasive Species Management Strategies: Adapting in the Arctic Brooks A. Kaiser ................................................................................................. 175

11.1 Introduction.....................................................................................................175

11.2 A Brief Overview of Species Introductions in an Arctic Context ................176

11.3 Management Overview of Invasive Species: Options for threatened states ................................................................................................................180

11.4 Prevention and Early Detection (ED) and Rapid Response (RR) Strategies........................................................................................................181

11.5 Control (Spatial Containment and/or Population Reduction) .....................183

11.6 Valuation of what is "at stake" ....................................................................184

11.7 Valuation techniques for Non-Market Resources Damaged by Invasive Species ................................................................................................186

11.8 Using valuations in invasive species management......................................188

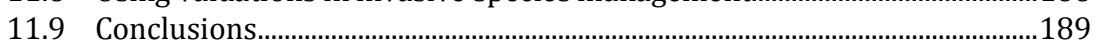

11.10 Works Cited .................................................................................................189

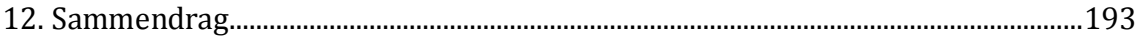

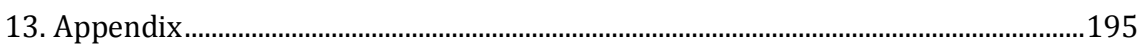

13.1 Program, Marine Invasive Species in the Arctic:..........................................195

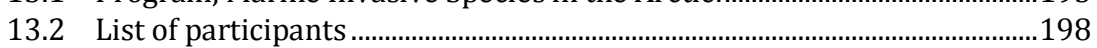





\section{Introduction}

Linda Fernandez, Virginia Commonwealth University, Richmond, Virginia, USA - Brooks A. Kaiser, Department of Environmental and Business Economics, University of Southern Denmark - Niels Vestergaard, Department of Environmental and Business Economics, University of Southern Denmark.

Arctic marine ecosystems are among the most productive and most vulnerable in the world, both from an economic and ecological perspective of growing accessibility. The complexity of Arctic marine ecosystems and their location poses challenges for management, valuation, and the establishment of sound policy to protect them. In recognition of these challenges and the importance of addressing some key threats, this special issue of Temanord presents papers from a workshop devoted to this topic sponsored by Nordregio and the University of Southern Denmark. In October 2013, a group of multidisciplinary scientific and economic experts on marine invasive species and the Arctic came together in Esbjerg, DK for a two-day workshop titled: "Marine Invasive Species in the Arctic: Management Issues". Attendees of the workshop came from academic, governmental and scientific institutions in Denmark and the Faroe Islands, Sweden, Norway, Finland, Iceland, Canada, and the United States. The workshop was organized by Brooks Kaiser, Linda Fernandez and Niels Vestergaard, who are engaged in a broader research project on Marine Resource Governance in the Arctic, with assistance by other partners in the project. This volume presents papers based on the presentations of the workshop speakers (see workshop program page 161).

The ideas behind the workshop, and this volume, are collaborative information sharing and network development intended to address the fact that the ecosystem changes underway in the Arctic region are expected to have significant impacts on living marine resources in both the short and long run. Current actions and policies adopted by the Arctic (Nordic) states over such resource governance will have serious and ultimately irreversible consequences in the near and long terms. The papers in the volume cover biology, ecology, economics, political science, and human development perspectives on marine invasive species. While specific examples are used to illustrate issues, the case studies presented 
are grounded in theoretical and analytical frameworks from all of these disciplines. Both academic and policy audiences can find inspiration from the well-rounded work contained here in thinking about how to develop and implement integrated policy rooted in natural and social science. Various options and outcomes of such policies are part of the papers presented with a variety of viewpoints and considerations.

Since Arctic marine ecosystems straddle international boundaries, policies to contain invasive species in one nation's waters will be limited in effectiveness by decisions of neighboring nations as well as by the ecological context of the invasion. Cooperation is the only way a shared environment can be sustained. Coordinated resource policy across space and time is therefore essential to maximizing the full economic value, including potential non-use and indirect-use values, of the living resources of the Arctic Ocean as the base productivity undergoes ecological changes. As such, the papers are interdisciplinary in nature and consider strategic and bio-economic aspects of the problem of marine invasive species.

Synergies between ecologists, economists and policy makers focusing on the unique challenges of marine invasive species in the Arctic bring focus to some important co-management and stakeholder participation issues in three main arenas. We describe these synergies here and direct the reader to chapters that enhance the discussions further. The volume offers awareness and exchange of ideas that in turn can lead to broader perspectives and different disciplines working in tandem.

Beyond identifying invasive species problems, the authors in this volume investigate public, private, government, civic, and academic actions to help in the policy and action to address marine invasive species. First, one group tackles how to enhance the civic society role of community monitoring to help potentially slow the invasion process and associated damages. Such effort presents a direct set of responses to the challenges of invasive species that can begin immediately. Mike Gill (Chapter 1), Joan Nymand Larsen (Chapter 2), and Oliver Floerl (Chapter 4) all address this question directly in their papers. Suggestions through examples include on-site training by marine ecologists as well as community-based information on existing ecosystem biodiversity, about which there is much formal scientific information missing. Chapter 1 also provides an overview of the potential consequences of ignoring the threats from invasive species in the Arctic from a biological perspective, while Chapter 2 focuses on the potential consequences for the human Arctic population.

A second arena for research is how to scientifically determine the most relevant threats, both economically and ecologically. This includes both different vectors and effective disruptors for marine invasions. While all 
papers in the collection touch on this to some degree, Section 2 on Shipping and Invasive Species in the Arctic addresses it head-on, while the two sections, 3 and 4, of case studies provide insights into the detailed information and analysis underway and needed for appropriately identifying these threats; the first case studies come from a primarily ecological perspective while the second case studies come primarily from an economic perspective. The final section broadens the discussion from the case studies into an applied theoretical understanding of strategic, bio-economic considerations for minimizing the impacts of marine invasive species in the rapidly changing Arctic environment.

Chapters 3 and 4, by A. Whitman Miller and Oliver Floerl respectively, summarize the state of knowledge and the state of action in options for addressing marine invasive species at various early stages of arrival and establishment, as well as the consequences of actions that are taken or opportunities that are missed to intervene. Maritime shipping and related vectors of marine invasive species are addressed with detailed examples from various settings that are relevant to the Arctic. Tying ongoing research on detection and response in oceanic conditions of the Arctic is key to the applicability of recommendations Miller and Floerl make.

The third arena for synergies comes from the case studies, which highlight the real ways in which policy directly affects transforming Arctic marine ecosystems, and vice-versa. The ability to see these connections works to strengthen the resolve of policy makers and researchers to work collaboratively for integrated management options. For example, the case studies on the spread and impacts of the Red King and Snow Crabs in Norway by Jan Sundet (Chapter 5) are almost as much management stories as they are ecological ones, and both economics and ecology must be combined in bio-economic assessments identifying, avoiding, and reducing damages from such cases.

Chapter 6, on Icelandic invasive species, by Gudrun Thorarinsdottir Karl Gunnarsson, and Ó. Sindri Gíslason, identifies new potential problem species that were only identified in the process of gathering material for the workshop. This will have immediate feedback effects on managing these species in Icelandic waters.

The case study on the risk of the Asian Clam's establishment in Finnish waters, Chapter 7, by Niemi et al. highlights the tradeoffs between management options at various stages of a potential invasion. This paper nicely illustrates the need for including economic analysis in ecological assessments and vice versa. The same is true of the Chapter 8 case study on Norwegian salmon, where Jan Olaf Olaussen guides the reader through a case where changing the age structure of the population 
through harvest decisions as related to invasive species management has differing economic and ecological consequences.

In the final section, the papers discuss broad lessons for invasive species management in bioeconomic and policy context. In chapter 9, Rasmus Gjedss $\varnothing$ Bertelsen looks at the different states and their policies and how they attempt to use their power to reach their goals suing international relation theory. He shows how these factors may influence the potential for and consequences of Arctic marine invasive species. Chapter 10 by Linda Fernandez presents analyses comparing cooperative and non-cooperative policy options that integrate economic incentives and biological dynamics of marine invasive species across several vectors of invasion for the Arctic. These analyses involve international maritime shipping with ballast water and bio-fouling, recreational boats, aquaculture and aquarium trade with suggestions to enhance current policy options that address the timing and scale of the problem. Chapter 11 by Brooks Kaiser applies an overview of invasive species management options from prevention through to adaption, including a discussion of valuation issues that often arise when evaluating invasive species management options, to the Arctic context.

These chapters accentuate the need for bio-economic integration for improved decision making regarding invasive species in the Arctic.

This workshop was the first in a series of workshops that will bring academic experts on the economics of living marine resources in the Arctic Ocean with resource managers and policy makers in order to advance understanding of management of these valuable resources and to develop flexible, ecosystem-integrated management solutions. The overall purpose of the project is to identify and provide guidance in solving the main governance challenges of the marine living resources in the Arctic Ocean with reduced ice presence. A variety of scales for marine resource use is considered as directly pertinent to the Nordic states, from local indigenous populations to a global level that considers worldwide demand for the resources present in the Arctic.

This publication has an associated project web-site, http://www.sdu.dk/ arctic. On the website you can find slides of the presentations from the conference and other relevant materials pertaining to the broader project. 
Section 1:

What's at Stake: Setting the Stage 



\section{Meeting the Challenge of a Changing Arctic}

Mike Gill, Biodiversity Observations Network and CBMP, Canada.

\subsection{Arctic Marine Biodiversity and Invasive Alien Species: What's at Stake?}

The Arctic Ocean and adjacent seas are unique and vulnerable marine ecosystems that present distinct challenges for effective invasive alien species management. The circumpolar Arctic, as defined by Conservation of Arctic Flora and Fauna (CAFF) Working Group of the Arctic Council, covers 14.8 million $\mathrm{km}^{2}$ of land and 13 million $\mathrm{km}^{2}$ of ocean roughly equalling an area three times the size of Europe (CAFF 2002; Figure 1). However, the Arctic Ocean is the world's smallest and is a unique marine ecosystem characterized and influenced by an extreme and highly variable climate resulting in seasonal ice-cover over its continental shelves and year-round ice cover over its center. Due to this ice-cover and the extreme seasonality of solar radiation, the Arctic Ocean experiences wide spatial and intra-annual variation in primary production with low productivity year-round in the central basin and high productivity in the summer season in the outer reaches of the Arctic Ocean and adjacent seas (e.g. Bering and Barents Seas) (Meltofte 2013). The Arctic Ocean is also characterized and influenced by large, seasonal inputs of freshwater from major continental river basins which play a significant role in physically structuring Arctic marine waters. These unique features have resulted in a correspondingly unique flora and fauna with an estimated 2,000 species of algae, tens of thousands of species of microbes and 5,000 marine animal species found in Arctic marine waters (Meltofte 2013), many of which have evolved to be highly adapted to the extreme and highly variable physical and climatic nature of Arctic marine ecosystems (e.g. Polar Bear, Narwhal, Walrus, Arctic Cod). During the short summer breeding season, 279 species of birds, many of which are seabirds, arrive from as far away as South Africa, Australia, New Zealand, and South America to take advantage of the long days and intense period 
of productivity (Petersen et al. 2004). Several species of marine mammals, including grey and humpback whales, and harp and hooded seals, also migrate annually to the Arctic. Arctic marine ecosystems are also unique in that they have, to date, experienced relatively little resource exploitation and are in a relatively pristine condition.

\section{Figure 1: CAFF Designated Area}

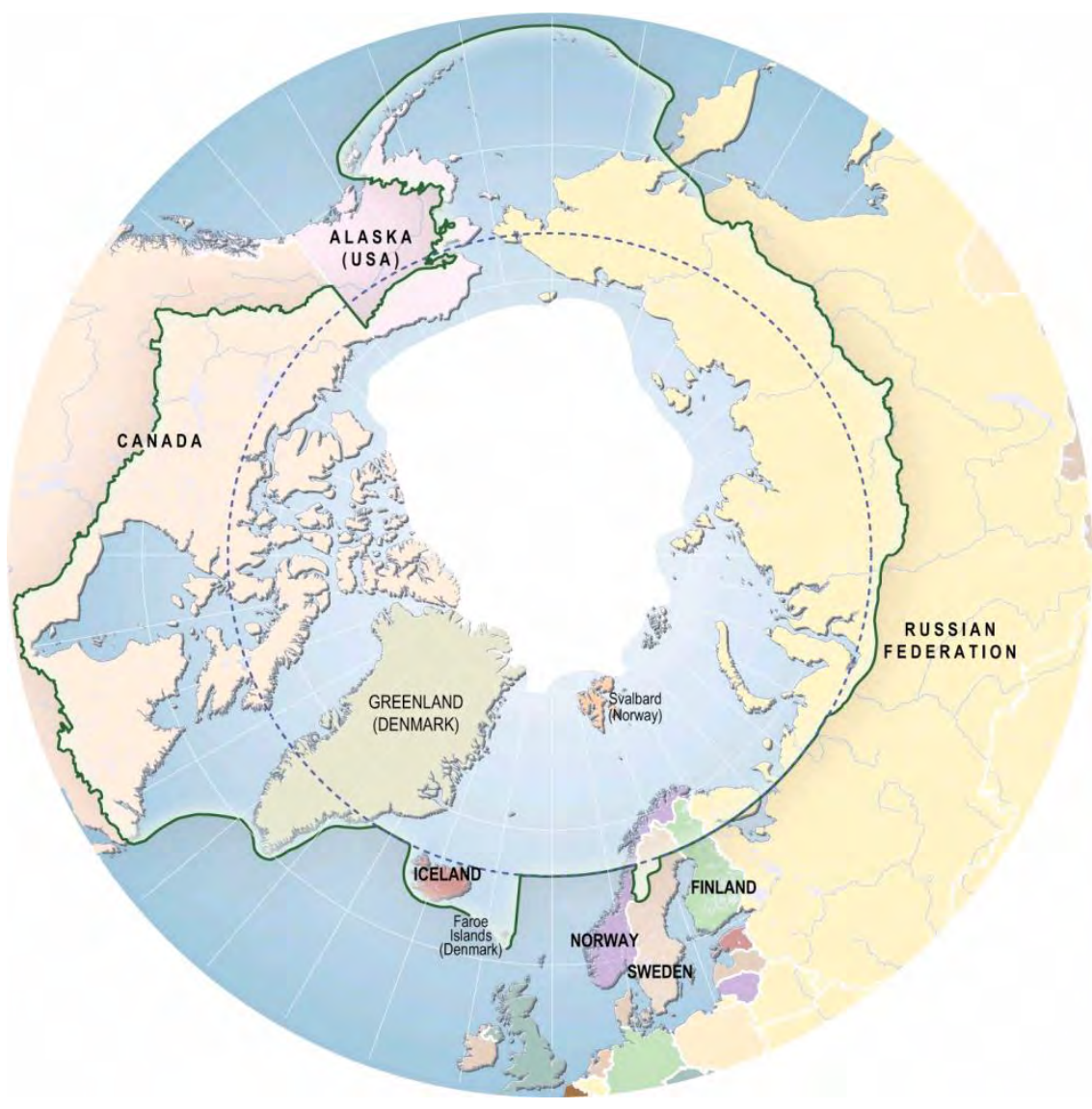

From CAFF International Secretariat.

The Arctic, however, has entered into a period of intense and accelerating change with climate change at the forefront. In the past 100 years, average Arctic temperatures have increased at almost twice the average global rate (IPCC 2007). Over the past thirty years, seasonal minimal sea ice extent in the Arctic has decreased by $45,000 \mathrm{~km} 2$ /year (Stroeve et al. 2007). The magnitude and pace of these changes is already exerting major influences and stresses on Arctic ecosystems. Some of the most rapid ecological changes associated with warming to date have occurred 
in Arctic marine environments. For example, net marine primary production has increased by an average of $20 \%$ across the Arctic between 1998 and 2009 and is strongly correlated with areas of sea-ice retreat (Frey et al. 2011; Figure 2). In some areas, the peak of marine primary production is occurring 50 days earlier than average and this may present some challenges (e.g. trophic mismatch ${ }^{1}$ ) for species who migrate annually to Arctic seas to take advantage of this (Frey et al. 2011). In addition, northward movements of non-native, sub-Arctic species have been detected in recent years. For example, in the Beaufort Sea, six fish species have extended their range from the Bering and Chukchi Seas to the Beaufort Sea as sea-ice has retreated and marine environmental conditions have consequently changed (Logerwell 2008). Orca whale sightings in the Eastern and Central Arctic (e.g. Hudson Bay, Hudson Strait, Foxe Basin, James Bay) have dramatically increased in the past 100 years (Higdon and Ferguson 2009; Figure 3).

These rapid changes associated with a changing climate are expected to make Arctic marine ecosystems more vulnerable to invasive alien species. For example, the prospect of ocean acidification in Arctic waters is expected to result in the consequent reduction in the biomass of benthic calcifying organisms which could lead to greater opportunities for invasive alien species to take hold in Arctic marine sediments (Fabry et al. 2009). Further, a number of marine invasive species are found in subArctic and temperate waters and, with warming sea-surface temperatures in the Arctic, the potential for their northward expansion increases (de Rivera et al. 2011). The northward movement of non-native species and introduction of truly invasive species risks the displacement of native Arctic species through increased competition, direct predation or through the introduction of new animal diseases. Species likely to be most affected by these changes are those with limited distributions, calcifying organisms or with specialized feeding habits that depend on ice foraging and those expected to experience altered recruitment timing and growth rates (Stachowicz et al. 2002). Limited functional redundancy in Arctic ecosystems makes them particularly vulnerable as the loss of a single species could have dramatic and cascading effects on an ecosystem's state and function (Post et al. 2009). All of these fundamental characteristics of Arctic marine ecosystems and the rapid changes they

\footnotetext{
1 Trophic mismatch - changes in seasonality of resource availability lead to constraints for wildlife unable to shift their life histories to take advantage of this shift in timing.
} 
are experiencing, have the potential to make Arctic marine ecosystems and the biodiversity they support more vulnerable to an emerging threat - invasive alien species. A warming Arctic and an ever-expanding global economy also facilitates increased human activity in Arctic marine waters (e.g. shipping, oil and gas exploration, shore-based developments, ports, etc.), which is expected to increase the potential for the transport and establishment of invasive alien species into a degraded Arctic marine ecosystem. Indeed, increases in the amount of ship activity in Arctic waters have been increasing in recent years (Meltofte 2013; Figure 4).

Figure 2: Trends in annual sea ice persistence and net primary marine production
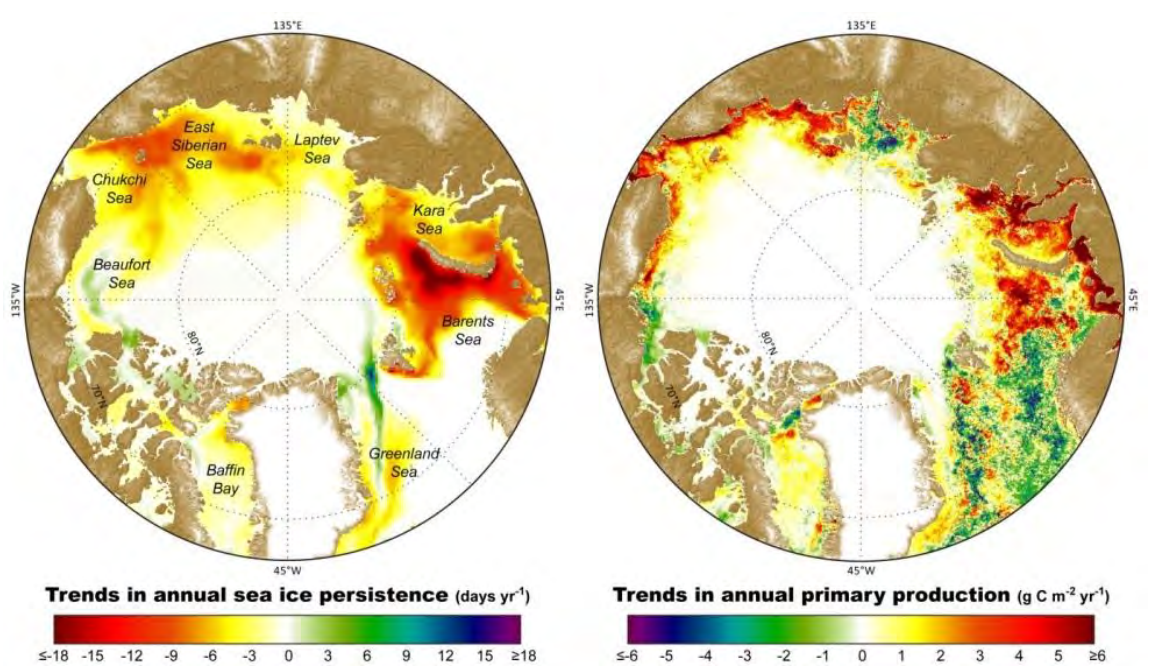

With permission from Frey et al. 2011. Arctic Report Card 2011. 
Figure 3: Trend in Orca whale (Orcinus orca) observations in the Hudson Bay region, Canada

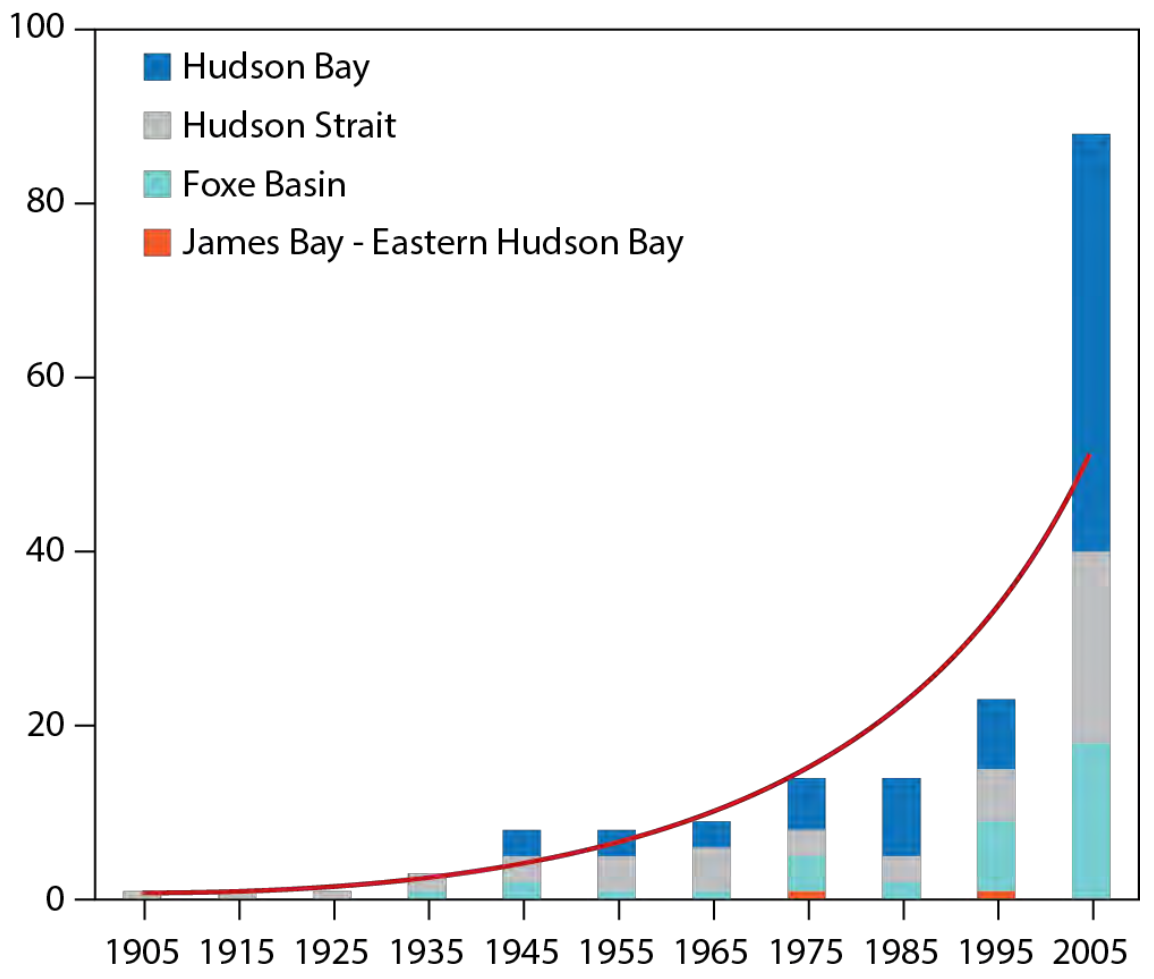

Sources: Hidgon \& Ferguson 2009 and Higdon et al. 2012. CAFF 2013. Arctic Biodiversity Assessment: status and trends in Arctic biodiversity. Chapter 14. Conservation of Arctic Flora and Fauna, Akureyri, Iceland. 
Figure 4: Number of ships a) transiting through the Northwest Passage (five year intervals from 1975 to 2009) and b) landing in Greenland (cruise ships only), from 2003 to 2008
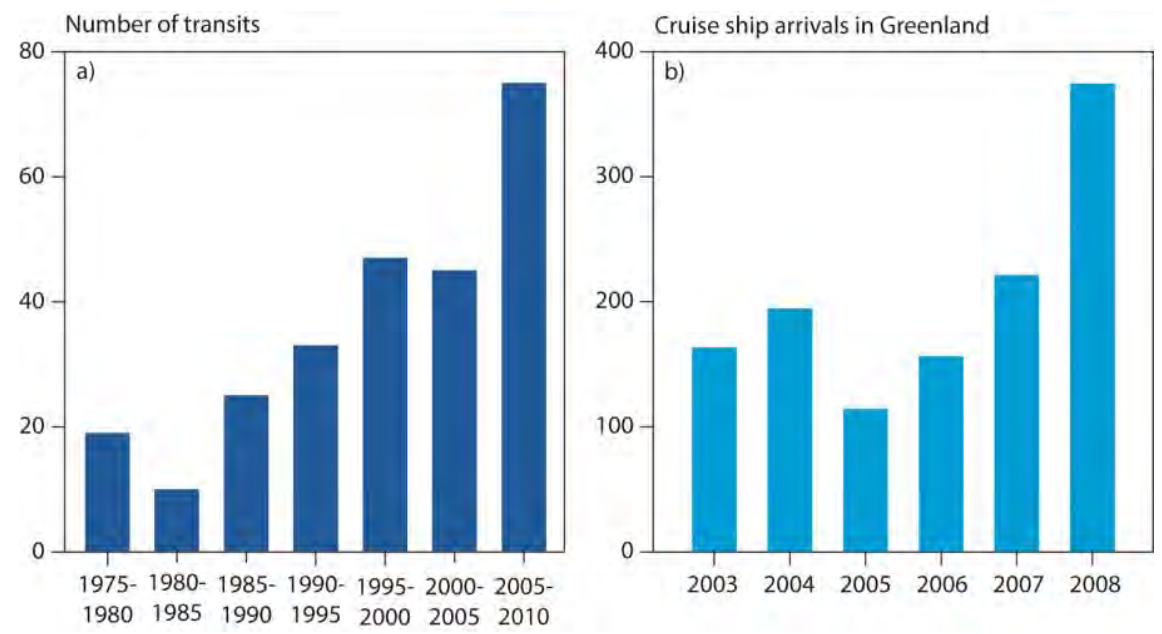

Sources: AMSA 2009 and NORDREG 2009. CAFF 2013. Arctic Biodiversity Assessment: status and trends in Arctic biodiversity. Chapter 14. Conservation of Arctic Flora and Fauna, Akureyri, Iceland.

\subsection{Meeting the Challenge of a Changing Arctic}

These ongoing and accelerating stressors on Arctic biodiversity provide a challenge in determining how best to respond to and take into account these changes when planning for the sustainable and effective management of the Arctic. To date, most of the focus on Arctic marine conservation issues has been on how to prevent, mitigate and/or adapt to the effects of climate change, over-harvest, contaminants, oil spills, and habitat alteration with little attention paid to the possible impacts and prevention of invasive alien species (Meltofte 2013). And yet, at a global level, invasive alien species are already a major threat to biodiversity, being further exacerbated by climate change (Mainka and Howard 2010) and, in many cases, causing irreversible harm. As a result, many countries are at least beginning to track information on the status of invasive alien species within their borders with many coastal nations having advanced surveillance and prevention programs in place at their port facilities. To date, over $30 \%$ of countries have adopted national legislation aimed at controlling invasive alien species (McGeoch et al. 2010) including most Arctic countries. However, for the Arctic Ocean, much of which lies beyond national jurisdiction, there remains no clear mechanism to ensure effective prevention, eradication and control of invasive alien species. 
The Arctic Council, however, represents an existing cooperative political structure that can be used to achieve effective technical and policy cooperation with regard to the prevention, detection and eradication of invasive alien species in Arctic marine waters. Existing Arctic Council programs, such as CAFF's Circumpolar Biodiversity Monitoring Program (CBMP), have much to offer. For example, the CBMP operates as a panArctic network of scientists and local resource users working together to improve our ability to detect, understand and report on important trends in the Arctic's biodiversity. As part of this, the CBMP has developed the Arctic Biodiversity Data Service (www.abds.is) - an interoperable, distributed, web-based data system where information on native biodiversity and, by extension, invasive alien and non-native species can be quickly and easily shared and presented, serving as a tool to facilitate early detection of emerging trends and thus, effective response. In addition, under Canada's Chairmanship of the Arctic Council from 2013 to 2015, Canada is leading the Safe Arctic Shipping Initiative. While this initiative is currently focused on the prevention of oil spills and other issues, this could present an opportunity to achieve a collaborative and coordinated approach amongst Arctic and non-Arctic nations on the prevention, detection and eradication of invasive alien species. As well, the International Maritime Organization is leading the development of a Polar Code to govern safe shipping practices in Arctic waters and thus, represents another opportunity to implement a coordinated approach to the prevention, detection and eradication of invasive alien species in Arctic marine waters.

In addition to these broad policy initiatives, there is an opportunity to better utilize and organize Arctic residents as key elements of an early detection network. Equipped with GPS enabled smart-phones, Arctic residents, many of which practice traditional lifestyles thereby spending much time on the land, could greatly increase our ability for early detection of potentially invasive as well as non-native species in Arctic waters thus facilitating rapid response.

Beyond this, the negative experience with invasive alien species on most of the rest of the planet means that many examples and tools are available that could easily be adapted for effective use in the Arctic. For example, the Global Invasive Species Database (www.issg.org/database/ welcome/) represents an online tool for tracking existing and potential new invasive species and could be a useful tool for risk assessment for the Arctic. Utilizing existing methodology for invasive species indicator development would facilitate better tracking and policy response to emerging trends and issues in Arctic marine invasive species. And finally, Antarctica's approach to detecting and preventing IAS in Antarctic 
waters should be investigated to see if these mechanisms and approach could be effectively applied in Arctic waters.

\subsection{References}

CAFF (2002). Arctic Flora and Fauna. Recommendations for Conservation. CAFF International Secretariat, Akureyri, Iceland.

De Rivera, C.E., Steves, B.P., Fofonoff, P.W., Hines, A.H., and Ruiz, G.M. (2011). Potential for high-latitude marine invasions along western North America. Diversity and Distributions 17: 1198-1209.

Fabry, V.J., McClintock, J.B., Mathis, J.T., and Grebmeier, J.M. (2009). Ocean acidification at high latitudes: the bellwether. Oceanography 22(4): 160-171.

Frey, K.E., Arrigo, K.R., and Gradinger, R.R. (2011). Arctic Ocean primary productivity. Arctic Report Card 2011.

Higdon, J.W. and Ferguson, S.H. (2009). Loss of Arctic sea ice causing punctuated change in sightings of killer whales (Orcinus orca) over the past century. Ecol. Appl. 19: 1365-1375.

Higdon, J.W., Hauser, D.D.W. and Ferguson, S.H. (2012). Killer whales (Orcinus orca) in the Canadian Arctic: Distribution, prey items, group sizes, and seasonality. $\mathrm{Ma}$ rine Mammal Science, 28: E93 - E109. doi: 10.1111/j. 1748-7692. 2011. 00489.x

Intergovernmental Panel on Climate Change (IPCC). (2007). Fourth Assessment Report of the Intergovernmental Palne on Climate Change, IPCC (WG I\&II). Cambridge: Cambridge University Press.

Logerwell, L. (2008). Cruise Report for the 2008 Beaufort Sea Survey. http://www.afsc.noaa.gov/refm/stocks/fit/pdfs/Beaufort_sea_cruise_report.pdf Mainka, S.A. and Howard, G.W. (2010). Climate change and invasive species: double jeopardy. Integrative Zoology 5: 102-111.

McGeoch, M.A., Butchart, S.H.M., Spear, D., Marais, E., Kleynhans, E.J., Symes, A., Chanson, J. and Hoffmann, M. (2010). Global indicators of biological invasion: species numbers, biodiversity impact and policy responses. Di versity and Distributions, 16: 95-108.

Meltofte, H. (ed.) (2013). Arctic Biodiversity Assessment. Status and trends in Arctic biodiversity. Conservation of Arctic Flora and Fauna Akureyi, Iceland.

Petersen, A., Zöckler, C., and Gunnarsdóttir, M.V. (2004): Circumpolar Biodiversity Monitoring Program - Framework Document. CAFF CBMP Report No. 1. CAFF International Secretariat, Akureyri, Iceland. 46 pp. ISBN: 9979-59526-9-5.

Post, E., Forchhammer, M.C., Bret-Harte, M.S., Callaghan, T.V., Christensen, T.R., Elberling, B., Fox, A.D., Gilg, O., Hik, D.S., Hoye, T.T., Ims, R.A., Jeppesen, E., Klein, D.R., Madsen, J., McGuire, A.D., Rysgaard, S., Schindler, D.E., Stirling, I., Tamstorf, M.P., Tyler, N.J.C., van der Wal, R., Welker, J., Wookey, P.A., Schmidt, N.M., and Aastrup, P. (2009). Ecological dynamics across the Arctic associated with recent climate change. Science 325: 1355-1358.

Stachowicz, J.J., Terwin, H.H., Whitlatch, R.B., and Osman, R.W. (2002). Linking climate change and biological invasions: ocean warming facilitates non-indigenous species invasions. Proceedings of the National Academy of Sciences 99: 15497-15500.

Stroeve, J., Holland, M.M., Meier, W., Scambos, T., and Serreze, M. (2007). Arctic Sea Ice Decline: Faster than forecast. Geophysical Research Letters 34(L09501) 2007. 


\section{Marine invasive species: Issues and challenges in resource governance and monitoring of societal impacts}

Joan Nymand Larsen, University of Akureyri, Iceland.

Approximately four million people live in the Arctic, and the majority of residents reside in communities along the Arctic coast (AHDR 2004; Forbes 2011). The Arctic - although small in size and with a relatively harsh climate - is a region characterized by its richness in peoples, societies and cultures and with human settlements ranging from small isolated and scattered communities to larger urban and industrial centers, and with variation in the relative importance of formal and informal economies (Larsen 2010a; Huskey 2010). An important characteristic is the close connection between Arctic residents and their surrounding environment, especially for many indigenous peoples - who number about $10 \%$ of the Arctic population - but also for a large segment of other Arctic residents (AHDR 2004; Aslaksen et al. 2009). These wellestablished human-environment connections contribute to the effects of global change being both strongly felt and immediate. For many Arctic residents the growing pressure to adapt to a changing environment is not only real but increasing, and for some it represents growing threats to their daily livelihoods and wellbeing. At the same time as economic and political autonomy is growing in the region, Arctic residents are confronted with an unprecedented combination of rapid changes including environmental processes, cultural developments, and economic changes. Traditional ways of life and nature-based livelihoods are met with increasing disruptions for many, thereby challenging the socioeconomic stability of local and indigenous communities. Many of the region's narrowly resource-based local and regional economies are facing increasing pressures by global change impacts, with these impacts being felt on employment opportunities, distribution of income and wealth, and the allocation of resources. Where communities are already 
stressed, even small changes in the availability or quality of natural resources may have large effects on their livelihoods (Larsen 2010; Rasmussen et al. 2009). Against this backdrop of increasing and multifaceted socio-economic challenges, the following offers some reflections on the societal impacts of marine invasive species in the context of global change, including brief considerations of issues and challenges in governance and monitoring.

Climatic change - including reductions in sea ice extent, duration, and thickness - will likely increase human presence and economic activities in the Arctic in the near to long-term (AMAP 2011; IPCC 2007). Increased marine invasions - including the introduction of invasive species through ballast water and vessel hulls - presents important ecological challenges for ecosystems and economic and cultural livelihoods in the Arctic (Lassuy et al. 2013; Arctic Resource Development 2012). Longer ice free seasons and reduced ice coverage could increase Arctic shipping (Stephenson et al. 2011; Arctic Council 2009; Prowse et al. 2009; Lawson 2010), and introduce new threats to food security and quality of life in the region (see Miller, Chapter 3 of this volume). For many local communities, continued access to resources is linked closely to livelihoods and overall wellbeing; just as access to living resources and a meaningful role in resource governance are closely tied to cultural survival for many (ASI 2010, 2014).

Consequences for Arctic local communities of an increase in marine invasive species and their ecosystem impacts may be further amplified when communities are located in areas which are particularly vulnerable to new activities competing for natural resources (Rasmussen et al. 2009). While Arctic indigenous peoples have a reputation for being resilient and for having an ability to adapt to changing environmental conditions, the multiple and compounding stressors confronting the Arctic today may leave many communities less resilient than witnessed earlier (AHDR 2004). Climatic change, increased human activity, including increased marine shipping, may lead to more marine invasions, including the potential demise of traditional subsistence systems, and with consequences for community viability (Arctic Council 2013). Climate change presents new challenges for institutions in the north to be more flexible, resilient and robust, and to find ways of increasing the ability to cope with rapid change in biological systems.

Marine invasions have potentially serious ecological, economic, cultural and human health impacts. External hull surfaces and internal ballast tanks of vessels can support a wide variety of non-native marine organisms. Much of the increased risk of invasion may come from in- 
creased shipping due to globalization and climate change, including Arctic cruise tourism. The present and projected future increase in ship traffic adds to risks of biological invasion. Ship-based tourism is a potential source of non-native species, and with the number of cruise ships on the rise, it has become an increasingly important pathway (Stewart et al. 2010; Lassuy et al. 2013).

Loss of Arctic biodiversity also means loss to the potential human uses of that biodiversity (Lassuy et al. 2013). Economic impacts in the Arctic may include the interference with fisheries in a variety of ways and scales, which can have potentially large effects for narrowly based economies, in particular when important commercial species, and species critical to subsistence based economic livelihoods, are affected.

Also, impacts may include disruption to tourism due to environmental impacts; damage to critical infrastructure; and potentially large costs related to cleanup, control and monitoring, and quarantine and treatment. Cultural impacts of marine invasions may include competition with native species important in subsistence harvest, and the degradation of habitats and resources important to cultural survival. Cultural impacts may be especially hard felt in predominantly indigenous communities. Here, the potential for conflict between industrial activities and economic and cultural interests of indigenous peoples is evident in cases where the water or impacted species in question are important for the survival of traditional livelihoods. The close ties between local economies, cultures and tradition in the Arctic makes it a growing concern for livelihoods and the state of human wellbeing. For example, invasive species may force traditional knowledge to adapt and new harvesting patterns to be developed. Marine invasions can also have impacts on health and wellbeing of Arctic residents, such as via introduction of disease and parasites. Additionally, they may decrease or destroy opportunities for recreation (Lassuy et al. 2013; Arctic Resource Development 2012; Forbes 2011).

The potential for significant economic, cultural, and health impacts of invasive species underscores the importance of finding viable long-term solutions in governance and risk management. Climate and weather conditions and long distances may hamper response action and restoration efforts. It is therefore important to establish procedures in the Arctic to address existing and emerging vulnerabilities and high environmental risks. A complicating factor in this regard is the lack of data to measure impacts. The vulnerable character of the Arctic, the economic, social and cultural complexities, differences between regions, including difficulties of monitoring, and still being in the early stages of relevant 
technology all present significant challenges to overcome. The more knowledge generated regarding the environmental conditions of the Arctic and the potential consequences of human activities, such as the consequences from increased marine shipping, the better the prospects will be for effectively addressing the challenges of marine invasions in ways that lead to fair outcomes for affected communities (ASI 2010; Arctic Resource Development 2012; Mikkelsen et al. 2011).

Many of the critical issues and questions related to the occurrence, consequences, and solutions to marine invasions remain challenging due to significant and persistent gaps in knowledge and lack of comprehensive community based monitoring programs for broad scale data collection and effective social indicator measurement (ASI 2010, 2014; Kannen et al. 2011; Mikkelsen et al. 2011). Furthermore, all human activity represents some type and level of risk, and therefore part of the answer to addressing the challenge of marine invasion is to find ways of assessing and managing the risk. This includes efforts to control the probability that an event will occur, or to limit the consequences of an event that will occur (Arctic Resource Development 2012; see Floerl, chapter 4 of this volume). This also makes it imperative that more be done in terms of exploring the question of acceptable levels of risks, the tradeoffs for different stakeholders and the development of mechanisms to better safeguard against intolerable risk levels. Risk may for example be reduced by cleanup or by introduction of measures such as the Polar Code (Arctic Resource Development 2012). Effective cleaning and treatment of ship hulls and drilling rigs brought in from other marine ecosystems also reduces risk. The increased threat to Arctic livelihoods from climate change and related impacts for marine ecosystems necessitates an assessment of risk, and the projected consequence for different economic sectors and social systems. This raises important questions about who should define the risks and benefits of society, what the tolerable levels of risk are or ought to be - which may differ between different Arctic stakeholders and regions. It also brings to the forefront issues of potential conflicts of interest over resource use by different stakeholders. There is a growing and urgent need for better assessment of Arctic vulnerabilities and risks.

On the question of governance, Caulfield (2004) emphasized as key trends in resource governance in the Arctic the growing importance of property rights, the incorporation of traditional or local ecological knowledge with western science in decision-making, the transfer or devolution of power to local decision makers and co-management, and the widening involvement of Arctic peoples in ownership and develop- 
ment of lands and resources (pp.121-137). These trends continue to be central to the protection of resources in the Arctic. But today, current challenges of resource governance have been extended to consider climate change, extensive land use change, and economic change concurrently occurring (AHDR 2014). Forbes et al. (2014) argue that to meet the challenges of sustainability, adaptive approaches to governance must be implemented- and these include flexibility in decision making, high levels of responsiveness, monitoring of social and ecological systems, and the active integration of knowledge systems. In general, it will be necessary in the future to find solutions that allow for a high capacity to be responsive to changing conditions, and to making decisions under conditions of greater uncertainty (AHDR 2014). While systems of governance that are particularly adaptive will have an important role to play in the near and long term, it is clear that efforts to establish a framework for effective monitoring of socio-economic impacts, including risks and mitigation measures will play a key role (ASI 2010, 2014; Kannen et al. 2011; Hoel 2011).

The development of cost-effective early detection monitoring networks will be a challenge due to the distribution of resources in the Arctic, just as the cost of primary data collection to enable measurement of social indicators and the assessment of human impacts presents significant challenges. Further development and implementation of such networks and monitoring systems would help facilitate more rapid and efficient response, and provide for better protection for more environmentally and economically efficient solutions early in a possible marine invasion process. Also, Arctic residents with traditional knowledge may greatly assist information gathering and monitoring by offering their observations and evaluations. Efforts to understand, manage, and respond to change in Arctic coastal systems may benefit from the integration and complementarily of both scientific and traditional approaches (Forbes 2011). Potential advantages of integrating various forms of knowledge include decision-making that is better informed and more flexible. Recognizing the value of traditional ecological knowledge may also contribute to enhanced resilience and adaptive capacity in many Arctic communities (ASI 2010; Kannen et al. 2011; Hoel 2011).

A critical step is to assess what information already exists and what information still needs to be gathered, and to address the issues and challenges to implementing monitoring and data collection. Important knowledge gaps can be closed through development of indicators and comprehensive modelling, mapping, monitoring, and analysis (Larsen 2009, 2010). The Arctic Social Indicators (ASI) project offers a first at- 
tempt at implementing a system for the long-term monitoring and tracking of change in human development in the Arctic (ASI 2010). Provided that appropriate adjustments are made, this system may offer valuable contributions towards meeting the challenge of obtaining reliable estimates of societal impacts of marine invasions in the Arctic. In particular, the ASI system includes among its six domain areas for indicator measurement, domains on economy, culture and health, as well as contact with nature. These domain areas are important to capturing the societal impacts of marine invasions in the Arctic. Other ASI domains include education and fate control. Specifically, the ASI system is based on the premise that Arctic communities highlight three aspects as key factors in their lives: fate control, contact with nature, and cultural wellbeing. The Arctic Human Development Report (AHDR 2004) and ASI found that for people in the Arctic, fate control, cultural integrity and contact with nature are central for well-being and should be included in future statistical data collection efforts. ASI aims to construct indicators that are valid across space, time, scale, and robust to change. Based on a series of case studies to test the strength of the indicators - including Sakha-Yakutia, the North West Territories, the West Nordic region (Greenland, Faroe Islands, Iceland, coastal area of Norway, Norwegian Sápmi), and the Inuit Regions of Alaska - the ASI report confirms the strength, applicability, and value of the monitoring system, and concludes that human development in the Arctic has been increasing, but that regional differences persist. An application of ASI to the case of societal impacts of marine invasions would be feasible via a series of targeted adjustments to specific indicators, but in addition would also require costly data collection including broad scale primary data collection on subsistence harvest and consumption. In particular, adjustments can be made to the ASI indicators for material wellbeing, cultural wellbeing, health, and closeness to nature (ASI 2010), to help capture specific impacts. For example, ASI indicators for material wellbeing include income generated from both formal and informal economic activity, but valid estimates of material wellbeing that takes into account impacts of marine invasions would need to account also for impacts on subsistence harvest. Similarly, ASI indicators for cultural wellbeing and closeness to nature must account also for harvest and consumption of country food; and cultural wellbeing can be measured also by participation in cultural activities - which may be negatively impacted by marine invasions. It is therefore feasible to apply the ASI system to the case of marine invasion by including data on these invasions, and by making appropriate adjustments to individual ASI indicators where needed, thereby enabling the measurement of so- 
cietal impacts to the economy, health and culture in the Arctic. A series of pilot studies could be implemented to help calibrate the way in which the ASI could be adjusted, so that invasive marine species risks and impacts are reliably picked up if and where they exist.

ASI has presented a series of recommendations for an ASI monitoring system, to be designed based on a set of principles and data criteria (ASI 2010), and to be made a priority for current and future circumpolar monitoring initiatives (ASI 2014). Such a system for human based monitoring will require a number of steps, including: the participation of national statistical agencies in development of a meta database to identify ASI indicators that are already monitored by a national agency; the establishment of an international task force composed of national statistical agency analysts and Arctic researchers to identify the special tabulations required to produce comparable ASI indicators; and the engagement of local communities, non-government organizations and private parties in developing and conducting locally-focused monitoring projects for social indicators, including community self-monitoring (ASI 2014; Larsen et al. 2010). The details of the methodology for such projects must be created via collaboration among communities, stakeholders and scientists. An important step will be to encourage national and international funding agencies and scientific associations to assist in building a circumpolar network of scientists actively engaged in monitoring of socio-economic well-being, and to promote data sharing, exchange and dissemination among researchers and research organizations (ASI 2010, 2014).

The goal of creating an Arctic human development monitoring system is to assist Arctic governments and communities to promote human development and quality of life in Arctic communities, and to help facilitate action to ensure and advance the wellbeing of all Arctic peoples. Improved access to reliable and high quality data at different scales and across regions will help facilitate the measurement and tracking of different domains of human development, and in turn may contribute to meeting the challenge of providing valid and robust estimates of societal impacts of marine invasions and facilitating more effective risk management and improved social outcomes for Arctic residents, their communities, and other stakeholders. 


\subsection{References}

AHDR (Arctic Human Development Report) (2004). Akureyri: Stefansson Arctic Institute. AHDR (Arctic Human Development Report) (2014). TemaNord. Nordic Council of Ministers: Copenhagen (forthcoming 2014).

AMAP (2011). Snow, Water, Ice and Permafrost in the Arctic (SWIPA): Climate Change and the Cryosphere. SWIPA Scientific Report. Arctic Monitoring and Assessment Programme. Oslo, Norway.

Arctic Council (2009). Arctic Marine Shipping Assessment 2009 Report.

Arctic Council (2013). Arctic Resilience Interim Report 2013. Stockholm Environment Institute and Stockholm Resilience Centre, Stockholm.

Arctic Resource Development ( 2012). Risks and Responsible Development. A Joint Report from FNI and DNV. Prepared for the ONS Summit 2012. Fridtjof Nansen Institute and Det Norske Veritas AS.

ASI (2010). Arctic Social Indicators - a follow-up to the Arctic Human Development Report. Larsen, J.N., Schweitzer P, Fondahl G (eds.). TemaNord:519, Nordic Council of Ministers, Copenhagen.

ASI (2014). Arctic Social Indicators. Larsen, J.N., Schweitzer P, Petrov, A., Fondahl G. TemaNrd. Nordic Council of Ministers, Copenhagen (in print).

Aslaksen, I., W. Dallmann. D. Holen, E. Hoydahl, J. Kruse, B. Poppel, M. Stapelton, and E.I. Turi (2009). Interdependency of subsistence and market economies in the Arctic. The Economy of the North. Glomsrød, S. and I. Aslaksen (eds.) pp. 75-97. Oslo: Statistics Norway.

Forbes D.L. (ed) (2011). State of the Arctic Coast 2010 - scientific review and outlook. International Arctic Science Committee, Land-Ocean Interactions in the Coastal Zone, Arctic Monitoring and Assessment Programme, International Permafrost Association. Helmholtz-Zentrum, Geesthacht.

Hoel, A. H (2011). Governance and Adaptation. In: Forbes D.L. (ed) (2011). State of the Arctic Coast 2010 - scientific review and outlook. International Arctic Science Committee, Land-Ocean Interactions in the Coastal Zone, Arctic Monitoring and Assessment Programme, International Permafrost Association. HelmholtzZentrum, Geesthacht.

Huskey, L. (2010). Globalization and the economies of the North. In: Heininen, L. and C. Southcott (eds.). Globalization and the Circumpolar North, pp. 57-90. Fairbanks: University of Alaska Press.

IPCC (2007). Climate Change 2007 - impacts, adaptation and vulnerability. Fourth assessment report, Intergovernmental Panel on Climate Change. Cambridge University Press, Cambridge.

Kannen A., Forbes D.L. (2011). Integrated Approaches to Coastal Change in the Arctic. In: Forbes D.L. (ed) (2011). State of the Arctic Coast 2010 - scientific review and outlook. Interbational Arctic Science Committee, Land-Ocean Interactions in the Coastal Zone, Arctic Monitoring and Assessment Programme, International Permafrost Association. Helmholtz-Zentrum, Geesthacht.

Larsen, J.N. (2007). Samfundsøkonomiske Udfordringer for Arktiske Regioner i Norden. In: Rafnsdóttir G.L. (ed) Antologi: Arbejde, Helse og Velfærd i Vestnorden. Háskólaútgáfan og Rannsóknastofa í Vinnuvernd, Reykjavík, pp. 13-26.

Larsen, J.N. (2009). Arctic Monitoring Systems. In: Climate change and Arctic sustainable development: Scientific, social, cultural and educational challenges. UNESCO Publishing, Monte Carlo, pp. 309-317.

Larsen, J.N. (2010). Northern Economies in a time of change. Baltic Rim Economies (BRE). 
Larsen, J.N. (2010a). Economies and Business in the Arctic Region. In: Lokacheva, N. (ed). Polar Law Textbook. TemaNord. Nordic Council of Ministers, Copenhagen. pp. 81-100.

Larsen, J.N.; P. Schweitzer; G. Fondahl; J. Kruse (2010b). Conclusion: Measuring Change in Human Development in the Arctic. In Arctic Social Indicators (2010). TemaNord. Nordic Council of Ministers. Copenhagen.

Larsen, J.N. and L. Huskey (2010). Material well-being in the Arctic. In: Larsen, J.N., P. Schweitzer, and G. Fondahl (eds.). Arctic Social Indicators, pp. 47-66. Copenhagen: Nordic Council.

Lassuy D.R., P.N. Lewis (2013). Invasive species: Human induced. Chapter 16. In: Arctic Biodiversity Assessment, 2013. Arctic Council.

Lawson, W.B. (2010). The Fast Changing Maritime Arctic. Proceedings of the US Naval Institute. pp. 54-59. www.usni.org

Mikkelsen, E., Hoel, A.H. (2011). Social, Economic, and Institutional State of the Circum-Arctic Coast. In: Forbes D.L. (ed) (2011). State of the Arctic Coast 2010 - scientific review and outlook. International Arctic Science Committee, Land-Ocean Interactions in the Coastal Zone, Arctic Monitoring and Assessment Programme, International Permafrost Association. Helmholtz-Zentrum, Geesthacht.

Prowse, T.D., C. Furgal, R. Chouinard, H. Melling, D. Milburn, and S.L. Smith (2009). Implications of Climate Change for Economic Development in Northern Canada: Energy, Resource, and Transportation Sectors. AMBIO: A Journal of the Human Environment, 38(5), pp. 272-281.

Rasmussen, R.O., Larsen, J.N. (2009). Future Challenges of the Arctic. In: Structural change in Europe - innovative city and business region, vol. 6. Harbarth Publications, Bollschweil. pp. 44-52

Stephenson, S.R., L.C. Smith, and J.A. Agnew (2011). Divergent long-term trajectories of human access to the Arctic. 1(3), pp.156-160.

Stewart, E. J., Howell, S. E. L, Dawson, J. D., Tivy, A. \& Draper, D. (2010). Cruise tourism and sea ice in Canada's Hudson Bay region. ARCTIC. (63) pp. 57-66. 

Section 2:

Shipping and Invasive Species in the Arctic 



\section{Melting Sea Ice, Accelerated Shipping, and Arctic Invasions}

A. Whitman Miller, Smithsonian Environmental Research Center, Edgewater, Maryland, USA

\subsection{Introduction}

Although ships have plied the world's ocean for centuries, polar waters have been significantly less connected by maritime trade than most other parts of the globe. This is especially true of the waters of the Arctic, where, until recently, extensive sea ice has precluded access throughout most of human history. While Nordic mariners and indigenous peoples have long inhabited and traversed coastal arctic waters, their vessels were neither as large, moved as fast, nor traveled as far as the modern ships of today. Under the growing influence of global climate change, shipping in arctic waters is undergoing a dramatic increase as the reduction in sea ice cover is opening the region to commercial navigation and exploitation of natural resources, in particular, petroleum and mineral extraction, and arctic fisheries (Ruiz and Hewitt 2009, Arctic Council 2009, Christiansen et al. 2014). It is not yet clear what impacts such human activities will have on the Arctic's ecosystems; however, the opportunity for biological invasions by marine organisms is certain to increase. The loss of sea ice is opening the Arctic to commercial shipping for several months per year (NSRIO 2014). New and expanded shipping activities in arctic waters under global warming create a new corridor for efficient global transport of commercial goods, but in so doing, inadvertently create a corridor for the inter-ocean transport of marine species in the ballast water and on the hulls of ships moving between the Atlantic and Pacific. These activities are expected to introduce potentially harmful non-native species to the Arctic as well as to enhance the introduction of non-native species across oceans and port systems at lower latitudes.

This chapter explores the role of shipping as it relates to the movement and introduction of marine species beyond their natural ranges, 
with particular focus given to shipping in arctic waters. Beginning with a short primer on marine invasion biology, this chapter then explores ships as non-native species vectors (i.e., via ballast water and hull fouling), highlighting expected changes to shipping in the Arctic. These processes are placed in the context of global climate change and the expectation of accelerating rates of shipping as they relate to a) shorter transport distances and times between oceans and b) the growing exploitation of arctic natural resources that rely heavily on shipping. Finally, a brief summary of the current international regulatory framework related to ships as vectors of non-native species (i.e., ballast water and sediments and to biofouling of ships' hulls) and a call for immediate consideration of vector management approaches are presented.

\subsection{Marine Invasions}

Once introduced to a region outside its biogeographical range, a species might fail immediately, persist without attaining a self-sustaining population, or develop a sustaining population that persists for some period of time. A self-sustaining population is the hallmark of a successful biological invader; however, depending on the extent of impact that a nonnative species has on the receiving habitat and environment (e.g., superior competitor, predator, or habitat engineer), a species may be considered "invasive". In general, invasive species are considered those that cause extreme ecological or economic damages, or that pose threats to human health. Three classic examples of truly invasive species that were likely introduced by commercial shipping are the zebra mussel (Dreissena polymorpha) invasion of the Great Lakes and fresh waterways of the United States; the comb jelly (Mnemiopsis leidyi) invasions of the Black and Caspian Seas; and the Northern Pacific seastar (Asterias amurensis) invasion of Australia.

Following introduction, there are two major factors that influence invasion success; that is, whether a species is able to survive, reproduce, and importantly, develop a self-sustaining population. The first is related to a species' physiological tolerance of a new environment. In the case of marine and estuarine species, environmental factors such as water temperature, salinity, and wave energy (e.g., open or sheltered coastline) have been shown to be important for shaping invasion success and failure, as has access to appropriate physical habitat. Thus, there needs to be a certain degree of match between a species' physiological tolerance and the environmental conditions of the non-native setting if an invasion 
is going to succeed. To some extent, an environmental match among native and introduced ranges can provide some insight into the likelihood of invasion success; however, environmental matching is a far from perfect predictor of invasion success.

A second factor is the biological resistance generated by native communities to would-be invaders, which can affect the vulnerability of a system to invasion. Once introduced, will a non-native species be able to gain access to sufficient food and shelter to generate a self-sustaining population, or will native species' competitive and predatory abilities be so great that the invader is precluded? Biological resistance to invasion is among the least well understood and difficult to predict aspects of invasion biology.

The availability of suitable habitat types for non-native species is essential for invasions to succeed. In the United States and elsewhere, marine invaders are most common in estuaries and other coastal embayments, often colonizing man-made habitats (pier pilings, coastal hardening structures, etc.; Ruiz et al. 2000a, Dumont et al. 2011).

The underlying reasons for enhanced invasion success in these settings are not fully understood, but may be related to a variety of conditions. For example, the common positioning of ports in sheltered embayments means increased propagule supply from shipping in an environment that typically has lower wave energy and lower rates of physical flushing, characteristics that can better retain propagules compared with open coast habitats where propagules may be dispersed rapidly. Propagule retention may increase encounter rates by mates, thereby increasing chances for successful reproduction (Floerl and Inglis 2003). Furthermore, port development alters the natural habitat significantly, including substantial additions of hard substrate, a habitat requirement of many invertebrate species that can be carried in ballast water or on the hulls of ships. Anthropogenic habitats have been shown to enhance colonization by non-native species as providers of novel habitats and potential refuges from native predators, thus significantly altering local ecological communities (Glasby et al. 2007, Bulleri and Chapman 2010, Dumont et al. 2011). Habitat disturbance associated with coastal development can also perturb the ecological integrity of native biological communities, including, as many believe, their ability to repel invasions by non-natives (Elton 1958, Byers 2002, Valentine and Johnson 2003). 


\subsection{Commercial Ships as Vectors}

Commercial ships are widely recognized as vectors by which biological organisms can move, albeit inadvertently, across oceans and beyond the bounds and barriers of their natural distributions (Carlton 1985, Ruiz et al. 2000a, Fofonoff et al. 2003, Hewitt et al. 2009). The vast majority $(>90 \%)$ of global cargo moves by commercial ships, providing extensive opportunity for the translocation of biota (Minchin 2006).

\subsubsection{Ballast Water}

Ships provide at least two significant mechanisms for the transport of non-native species. The first is ballast water, water that is taken into specialized ballast tanks or cargo holds in order to stabilize empty or partially loaded ships in various sea states and weather conditions. Ballast water also ensures proper trim and steering of the vessel. Ballast water, and its associated sediments, are typically taken aboard and discharged in connection with the off- and on-loading of a ship's cargo, meaning that most ballasting operations occur in ports and coastal waters. Importantly, in addition to the water itself, the biota suspended in the water column (e.g., zooplankton, phytoplankton, larval stages of invertebrates and fishes, as well as bacteria and viruses) are entrained with the water and deposited in ships' ballast tanks (Carlton 1985, Carlton and Geller 1993, NRC 1996, Ruiz et al. 2000b). Those ballast water inhabitants that do not expire inside a tank during transit can be discharged into ports as cargo is taken aboard the ship.

\subsubsection{Hull Biofouling}

A second important ship-related invasion vector for biological transport is on the exterior surfaces of ships' hulls where organisms cling. Socalled "biofouling" or "hull fouling" (Godwin and Eldredge 2001, Gollasch 2002, Hewitt et al. 2009) occurs on the wetted hull surfaces of ships as well as in and around specialized niche areas such as sea chests, bow thrusters, propellers, anchors and chains, and untreated dry docking support surfaces (Coutts and Taylor 2004, Inglis et al. 2010). Biofouling can consist of microorganisms that begin developing biofilms within hours of a hull making contact with water to more complex communities of sessile macrofauna and flora (e.g., barnacles, sponges, sea squirts, mussels, algae) that accumulate over weeks to years. In fact, niche areas, especially those that are removed from the shear forces created by wa- 
ter moving by the hull, can harbour mobile organisms like crabs or seastars. In a broad range of geographic locations, hull fouling appears to be as important and sometimes more important than ballast water as an invasion vector for non native species (Cranfield et al. 1998, Fofonoff et al. 2003, Hewitt et al. 2004, Davidson et al. 2009, Ruiz et al. 2011, pers. comm. Davidson IC).

Hull biofouling is not new, historically wooden hulled vessels were plagued by boring shipworms, which could compromise the mechanical integrity of the hull (Carlton 2001), but other species were also moved on these hulls. Prior to the 1880s, when the first steel hulled vessels were developed, wooden hulls were sometimes clad with copper or other substances to reduce biofouling (Hewitt et al. 2009). Modern steel hulled vessels are immune from the kinds of damage faced by wooden ships, however, the biofouling of hulls can induce significant drag on a moving ship which results in lower fuel efficiency, adding substantially to operating costs (Minchin 2006). To combat hull fouling and corrosion, the shipping industry has developed antifouling coatings that contain a variety of biocidal agents that kill or repel biofouling (e.g., copper and now banned tributyl tin (TBT)) or substances that make the hull surface slippery so that organisms are unable to cling or remain attached, especially as a ship moves through the water a particular speeds and for lengths of time (see Chambers 2006 for in depth description of antifouling agents and approaches). Due to negative environmental impacts from TBT and related organotins on natural marine communities, these widely used (and very effective) antifouling agents were outlawed internationally as an ingredient in antifouling paints in 2003 under the International Maritime Organization's International Convention on the Control of Harmful AntiFouling Systems on Ships (AFS 2001). In the absence of antifouling compounds of similar or greater efficacy, both Nehring (2001) and Hewitt et al. (2009) have suggested that the discontinuation of organotin may actually result in an increased risk of hull fouling invasions worldwide.

Both the ballast water and hull fouling vectors move living biota in vast numbers and over significant distances, often introducing them widely to regions well outside their native geographic distributions (Carlton 2001, Ruiz et al. 2000a, Fofonoff et al. 2003). The relative lack of shipping activity in arctic waters has meant that these high-latitude regions have experienced little in the way of non-native species propagule pressure (Ruiz and Hewitt 2009, Ware et al. 2014). Here propagules are considered organisms of various life stages, be they adults, juveniles, larvae, or cysts/resting stages. Propagule pressure is composed of two components, 1) the number of propagules introduced, and 2) the frequency of inocula- 
tion events. Propagule pressure has been shown to strongly influence the likelihood of invasion success (Lockwood et al. 2005, Verling et al. 2005, Johnston et al. 2009). Yet there remains significant uncertainty as to the exact relationship between propagule pressure and a quantifiable risk of invasion (Minton et al. 2005, NRC 2011). Nevertheless, despite scientific uncertainty surrounding this relationship, there is broad agreement that reductions in propagule pressure should lead to significantly lowered risk of invasion (Verling et al. 2005, NRC 2011).

\subsection{Arctic and Trans-Arctic shipping}

Maritime activities in the Arctic, both historic and contemporary, are no doubt complex and driven by the interests of multiple nations, both inside and outside the Arctic region (see Arctic Council 2009, Zellen (ed.) 2013 for recent treatments of this subject.) Although there are many drivers affecting polar shipping, the perceived economic benefits from the exploitation of natural resources (both living and non-living) and the use of arctic waters as a shipping corridor to further connect economies of the Atlantic and Pacific appear paramount, but safe passage through icy arctic waters will remain challenging (Arctic Council 2009, Lawson 2013). An international research team lead by the United States Geological Survey has estimated that approximately $13 \%$ of the world's conventional oil ( $\sim 90$ billion barrels) and 30\% of the world's natural gas ( $\sim 1.67$ trillion $\mathrm{ft}^{3}$ ) may occur north of the Arctic circle, with the majority of gas to be found in Russia (Gautier et al. 2009). High latitude oil exploration and extraction have taken place in the Arctic for over 5 decades, but as global warming reduces the extent of sea ice coverage, accessibility is expanding rapidly and technical obstacles are falling away. Geopolitical considerations and impediments to petroleum and mineral extraction have also played important roles in the tempo of these activities.

With the recent signing and ratification (2010 and 2011 respectively) of the Maritime Delimitation and Cooperation in the Barents Sea and the Arctic Ocean treaty between Norway and Russia, a territorial dispute that strongly limited shipping and undersea petroleum exploration for decades was resolved. This treaty opened up approximately $175,000 \mathrm{~km}^{2}$ of the Barents Sea and Arctic Ocean to oil and gas exploration (Amos 2011), a region suspected rich in petroleum reserves. Importantly, the agreement between Norway and Russia has cleared the way politically for commercial ships carrying commodities and tourists, as well as fishing vessels, to pass through and use these waters without fear of legal retribution. 


\subsubsection{Northern Sea Route and Destination Voyages}

The Russian Federation established the Northern Sea Route Administration, a body that issues permits, regulates and assists commercial vessels passing the approximately 3,000 miles along the Siberian peninsula from west to east (from Barents Sea to Bering Straits) and east to west (NSRA 2014). The Northern Sea Route (NSR) represents a new seasonal shipping corridor for commercial ships moving between Europe and Asia, as well as among ports and places along the route; for example moving liquid natural gas from Russia to Europe or Russia to China. The first commercial bulk carrier ships navigated the NSR in 2009 (Evers 2013) and in 2010, the Norwegian Tschudi Shipping Company in cooperation with other shipping companies pioneered some of the first nonRussian shipping across the NSR from Europe to China (TGSC 2010). Since 2009, the number of ships making passage has increased significantly to 71 transits, carrying 1.29 million tons of cargo during the 2013 shipping season. Additionally, over 350 permits were issued in 2013 for ships to operate inside the Northern Sea Route (NSRIO 2014).

Table 1 summarizes some of the apparent economic incentives and disincentives for using this new inter-oceanic corridor.

Table 1: Examples of economic incentives and disincentives to Arctic transits via the Northern Sea Route
\begin{tabular}{ll} 
Incentives & Disincentives \\
Fuel savings & Reinforced hulls \\
Time savings & Passage fees \\
Draft restrictions/ DWT limitations & Icebreaker escorts \\
Piracy reduction & Seasonality \\
\hline
\end{tabular}

In addition to growing use by ships transiting from Europe to Asia and vice versa in arctic waters, the number of destination voyages (i.e., ships that travel into polar waters for specific operations such as petroleum exploration, exportation of liquefied natural gas at LNG terminals, tourist visits by passenger vessels, and commercial fishing) are expected to far outstrip transits (Lawson 2013).

The economic drivers of both NSR transits and destination voyages in the Arctic appear enormous, but the environmental costs of such activities, including those of marine invasions, although less easily monetized, should be considered carefully as we expand our considerable and likely irreversible influences in the Arctic. Deliberations must be multinational, including indigenous peoples, and should occur in a variety of policy and regulatory fora (e.g., the Arctic Council, United Nations' International Maritime Organization (IMO)). 


\subsubsection{Polar Code}

The Polar Code, an international agreement of the International Maritime Organization (IMO) is designed to develop and codify specific international rules and regulations for ship safety and construction in the Arctic and Antarctic. Pending finalization, the Polar Code is expected to enter into force in 2016 (IMO 2014, Koranyi 2014). Importantly, the Polar Code sets forth operational safety measures and rescue regulations for ships operating in high latitude waters, as well as certain environmental and pollution prevention protections to reduce risks of oil/chemical spills. However, the Polar Code is silent on issues of invasive species that are associated with ballast water discharge and hull fouling of ships and other maritime structures such as mobile offshore drilling platforms.

All vessel operations in the arctic region pose potential risks for the introduction or regional dispersal of non-native hull fouling species. Invasion opportunity is also present for those vessels that discharge ballast water, with those ships that do not follow any sort of ballast water management or treatment posing the greatest risk. Tanker vessels that export Russian and Norwegian liquefied natural gas (LNG) will be continual and repeated sources of large volumes of foreign sourced ballast water from the geographic regions of their customers (e.g., European countries in the Atlantic and Asian countries in the Pacific). Likewise, the hulls of these same ships will generate large fluxes of wetted surface area with significant potential for biofouling. Dedicated routes for specialized products like LNG may pose particularly great risks for marine invasions, since the likelihood of repeated introductions of large numbers of propagules is high. In the case of Arctic LNG, large new terminals are being planned with the expectation of serving both Europe and Asia (e.g., in Sabetta, Russia; Evers 2013). Nevertheless, this situation also provides a unique opportunity for the consideration of land-based or nearshore ballast water reception/treatment facilities, an invasion prevention solution that is not suitable in most ports, but which may be economically feasible if originally designed as part of a specialized LNG terminal.

\subsection{Climate Change}

Arctic land and sea surface temperature are warming at faster rates than other parts of the globe; permafrost, snow cover, and sea ice are retreating, trends that are expected to increase in the coming century (IPCC 2013). These changes to the environment will increase human activities 
in the Arctic considerably. For example, increased shipping and changing trade patterns, petroleum and mineral exploration, extraction and export, coastal and port development, tourism, fishing (both harvest of natural stocks and increased aquaculture), and anthropogenic debris are each expected to result in greater opportunity for invasions in the Arctic (Ruiz and Hewitt 2009). In fact, shipping will underpin all of these activities. Therefore, when increased propagule pressure from shipping traffic is combined with habitat disturbance and alteration, and changes in sea ice cover, water temperature, sea level rise, and salinity, it is reasonable to assume that the rate of non-native propagule transport to the Arctic is likely to increase.

\subsubsection{Migration and Natural Dispersal}

A study by Vermeij (1991) documented natural migrations of molluscs that occurred during the Pliocene epoch, the last period when the Arctic is known to have been ice-free (5.3 to 1.8 million years before present). Migrations were strongly asymmetrical, with 261 species moving from the North Pacific to North Atlantic, and just 34 species moving in the opposite direction. Vermeij attributes this pattern to strong prevailing currents that moved northward through the Bering Strait and hypothesizes that a lack of sea ice enabled phytoplankton concentrations to increase via warmer temperatures and increased light penetration/photosynthesis, which in turn fueled migrations. Recurrence of an ice-free Arctic will no doubt support natural dispersal and migration, but will concomitantly enhance environmental conditions for transport and post-arrival survival of biota moved by humans.

The discovery of a North Pacific diatom species (Neodenticula seminae) in the Laborador Sea in 1999 by Reid et al. (2007) indicates that the reduction of arctic sea ice has influenced water circulation current patterns, enabling a species that has not occurred in the North Atlantic for 800,000 years to migrate between oceans. The authors discuss ballast water as a possible vector for the diatom, but conclude that given the small number of ships and volume of ballast water moving between the two regions in the late 1990s, ballast water was an unlikely vector. With shipping in the Northern Sea Route on the rise and the transit of the first commercial coal carrier through the Northwest Passage in 2013 (McGarrity and Gloystein 2013), active shipping and ship vectors (ballast water and biofouling of hulls) in the Arctic, and connecting the Pacific and Atlantic will surely increase propagule pressure and invasion opportunity. 


\subsubsection{Modeling and Experimental Approaches to Invasion and Invasibility}

Given the diversity of biota and vectors in play, predicting the next important invasive species is impossible. However, examining the physiological capacity to withstand environments beyond current geographic distributions can provide insight. Using a niche modeling approach that incorporates a suite of environmental parameters reflective of current species' distributions (MaxEnt, see Elith et al. 2011), deRivera et al. (2011) modeled the capacity for several marine invaders (e.g., crab, barnacle, tunicate, snail) of the Pacific coast of North America to tolerate higher latitude regions of Alaska under projected environmental scenarios of 21st century conditions (IPCC 2007). These models predicted that changing climate in Alaska would create environmental conditions tolerable to the species studied. When model projections were expanded globally for year 2100 IPCC projections, most of the species were shown to have physiological capacity to withstand future conditions in some parts of the Arctic (B. Steves and C. deRivera, unpublished data).

Using a shipping vector based approach (global port connectedness to the Svalbard archipelago, Norway) combined with the changing environmental match of seawater temperature and salinity under the RCP8.5 emissions scenario (IPCC 2013), and qualitative estimates of propagule pressure, Ware et al. (2014) estimated the risk for invasions to Svalbard. Their modeling suggested that in the second half of 21st century, Svalbard will be increasingly vulnerable to invasion as a function of climate change and increased propagule pressure from ships.

Beyond theoretical modeling approaches, experimental methods can be applied to test various aspects of invasion biology. Experiments that test physiological tolerance of biota are common in many areas of study (e.g., toxicology/ecotoxicology). Agricultural sciences have long sought to understand how to optimize growth and production of crops, but have also invested extensively in the study and application of biological control of invasive species. Likewise, ecologists have used field experiments extensively to understand community assembly rules and the drivers of biodiversity, including invasion dynamics (e.g., Sousa 1979, Stachowicz 1999). Marine invasion biologists are increasingly using laboratory and field experiments to understand various aspects of marine invasions such as the role of propagule pressure on invasion success (e.g., Clark and Johnston 2005). Using field experiments, Crooks et al. (2011) tested the differential effects of copper on naturally occurring assemblies of native and non-native species in San Francisco Bay. The investigators found that native diversity was reduced significantly more than non-native diversity, 
when exposed periodically to a copper solution. To understand the survivorship/mortality of would be invaders, researchers from the Smithsonian Environmental Research Center are using an experimental test platform to simulate ship voyages that apply actual shipping route conditions, a method they are now applying to possible biofoulers of commercial ships that transit the Arctic (GM Ruiz, personal communication).

To most rapidly advance our understanding of arctic invasions, it is incumbent that investigators employ all methodologies at hand, with a goal toward educating managers and policy-makers about what can be expected and what might be done to reduce the number and ameliorate the impacts of marine invaders.

\subsection{Ocean acidification}

An additional driver of global change is the acidification of oceanic waters due to increasing carbon dioxide $\left(\mathrm{CO}_{2}\right)$ concentrations. As $\mathrm{CO}_{2}$ increases in the atmosphere, the surface waters of the ocean absorb significant portions ( $>25 \%$ ), driving the system toward an air-sea equilibrium (Sabine et al. 2004, Royal Society 2005). In seawater, higher $\mathrm{CO}_{2}$ results in lower $\mathrm{pH}$ (more acid) and a lowered bioavailabilty of carbonate ions for the biogenic generation of calcium carbonate, the building block of calcareous biota (Orr et al. 2005). Water that is high in $\mathrm{CO}_{2}$ will be reduced or even under-saturated with respect to aragonite and calcite, two mineral forms of calcium carbonate used by many calcareous organisms to generate hard body parts. Because cold waters are able to absorb $\mathrm{CO}_{2}$ more readily than warm waters, the chemistry of acidification in highlatitude ocean regions is expected to be more accentuated than in temperate and tropical regions (Fabry et al. 2009).

To date, investigators have shown a variety of biological responses to ocean acidification and discovered that not all taxa respond similarly, even demonstrating species-specific responses among closely related biota (see Doney et al. 2009 for review of ocean acidification and biological responses to it). A recent meta-anlaysis of five important animal taxa (corals, echinoderms [starfish and sea urchins], molluscs [bivalves, snails], crustaceans [crabs, shrimp, barnacles, and fishes] indicated differential responses to elevated $\mathrm{CO}_{2}$ (Wittman and Pörtner 2013). The corals, echinoderms, molluscs, and larval fishes appear to be more sensitive to elevated concentrations of $\mathrm{CO}_{2}$ (i.e., $936 \mathrm{ppm}$ in year 2100 projected under the IPCC's RCP8.5 scenario) than do crustaceans, generally showing diminished performance and deleterious effects in calcification, growth, metabolic pro- 
cesses, and behavior. Elevated $\mathrm{CO}_{2}$ and reduced $\mathrm{pH}$ has dramatic effects on certain species of pteropods, free swimming pelagic snails that build aragonite shell structures (i.e., dissolution of shells within hours of exposure to conditions projected for the 21st century; Orr et al. 2005, Fabry et al. 2009). Pteropods occur at high densities and have been shown to be very important prey to juvenile pink salmon, $(>60 \%$ by weight, Armstrong et al. 2005). Phytoplankton too show variable responses, both among calcifying (e.g., cocolithophores) and non-calcifying species. Recent mesocosm studies carried out off the coast of Svalbard, Norway indicate that the smaller phytoplankton (nano and picoplankton) thrive under high $\mathrm{CO}_{2}$, but that larger phytoplankton suffer due to strongly reduced levels of essential nutrients, suggesting important foodweb and biogeochemical effects from acidification (Riebesell et al. 2013). Fabry and colleagues (2009) review the effects of ocean acidification at high latitudes on both ocean chemistry and biotic responses, and recommend that polar waters be viewed as bellwethers for the rest of the globe.

At present, it is still too early to predict the ecological-scale effects of acidification in arctic waters; however, given the mounting evidence of negative biological effects on species that reside in the water column and benthos, changes to arctic ecology may alter community structure and function, thereby changing the biological resistance to non-native species. A growing number of studies performed near natural volcanic underwater $\mathrm{CO}_{2}$ seeps indicate strong effects on community assembly and diversity of benthic biota (Hall-Spencer et al. 2008, Kroeker et al. 2011), further suggesting that opportunities for invasion by non-native species will likely change in a high- $\mathrm{CO}_{2}$ world.

\subsection{Drivers and Determinants of Invasion Opportunity and their Interactions}

Human induced global climate change, caused in part by the increased extraction and burning of fossil fuels, is rapidly influencing both the physical and biological realms of the Arctic region (IPCC 2007, 2013). Among the most important changes are increasing ocean temperatures and the loss of sea ice coverage in polar waters. These and other environmental changes may have direct effects on ecological communities of the Arctic, which in turn may influence their vulnerability to marine invasions. Such changes are already having direct effects on the number of commercial ships operating in the Arctic, and are expected to factor in greatly to the extent of natural resource exploration, extraction, and 
export that take place in the Arctic. Climate-induced shifts in shipping patterns and natural resource exploitation of the Arctic will alter the landscape and seascape in many ways that will influence invasion opportunity (Ruiz and Hewitt 2009).

Figure X.1 is a concept diagram summarizing how anthropogenic greenhouse gas emissions influence climate change and ocean acidification processes, thereby affecting the opportunity for Arctic invasions both directly and indirectly, through other human-mediated activities. While not comprehensive, the diagram is meant to be illustrative of some important interaction of environmental change, human behavior, and arctic invasions. For example, shipping directly affects the volume of ballast water delivered, but shipping activities are directly influenced by sea ice coverage. Rising water temperatures have direct influences on invasion opportunities as well as direct effects on currents and patterns of ocean circulation, which themselves will also affect dispersal of both native and non-native species. Natural resource extraction will enhance greenhouse emissions (the fundamental driver of all the pictured interactions), but will also strongly influence shipping, coastal development/habitat degradation, each of which will affect invasionopportunity.

Figure X.1: Concept diagram

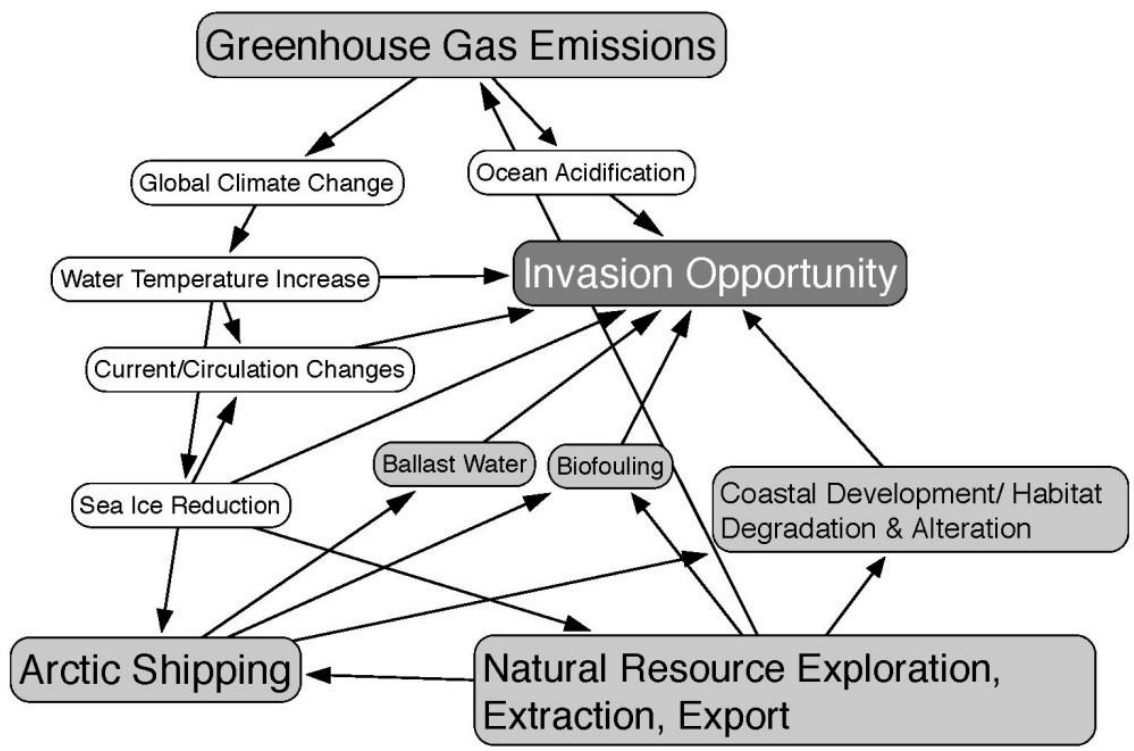

Concept diagram relating invasion opportunity to anthropogenic greenhouse gas emissions, global climate change, ocean acidification, arctic shipping/vectors, and natural resource exploration/extraction. Arrows indicate directionality of effect, but not strength of interactions. Environmental effects of to greenhouse gas emissions are depicted in white, human activities in light grey, and invasion opportunity in dark grey. 


\subsection{Ship Vector Regulations}

Although various countries have developed legally enforceable statutes and regulations for ballast water management (e.g., Australia, Canada, New Zealand, and the United States), the primary international effort to reduce risks of marine invasions is the IMO's International Convention for the Control and Management of Ships' Ballast Water and Sediments (BWM Convention) which was adopted in 2004. However, not until 12 months after $30+$ maritime countries, representing $35 \%$ of the global shipping merchant tonnage, ratify the convention can it enter into force as an international treaty (Albert et al. 2013). Although the IMO began seeking international protections against ballast water-borne invasions in the 1980s (Hewitt et al. 2009), it was not until 2004 that numerical discharge standards were considered internationally (i.e., specific concentrations of viable biotic propagules of 3 size classes: $>50 \mathrm{um}$ minimum dimension, $>10 \mathrm{um}$ and $<50$ um minimum dimension, and certain indicator microbes; Albert 2013). Currently, the United States via the U.S. Coast Guard and U.S. Environmental Protection Agency have assumed the BWM Convention's socalled "D-2 Ballast Water Performance Standards" as the basis for ballast water management and discharge (see Albert 2013 for a more detailed analysis of international BW regulations).

Unfortunately, the process for seeking international agreements/treaties on reducing the risk of ballast water invasions has been arduous, and despite apparent recent progress, a treaty will likely take years to fully implement since it will require the development, type approval testing, and installation of onboard ballast water treatment systems on existing ships and new builds. Until such time, many view openocean ballast water exchange (BWE, the process of exchanging coastal ballast water and the coastal biota it contains with pelagic water/biota, prior to discharge in subsequent ports or coastal ecosystems) as the best interim management method for reducing marine invasion risk.

It is of interest to note that as of this writing, five of eight member sates of the Arctic Council have ratified the IMO BWM Convention (Norway, Russia, Canada, and Denmark, and Sweden), but the United States, Finland, and Iceland have not. Although not a signatory, the United States' federal regulations require mandatory ballast water reporting and management of overseas ballast water and the vast majority of vessels report ballast water management of some kind, either open ocean BWE, no discharge of BW, or use of an alternative onboard BW treatment system (National Ballast Information Clearinghouse Reports to United States Coast Guard (NBIC 2014), but see Miller et al. 2011 for 
discussion of some limitations of ballast water exchange). It is encouraging that acknowledgement of marine invasion risk and ballast water management is common among Arctic nations, suggesting that international cooperation on this issue may be achievable.

Despite widespread concern for marine invasions associated with hull fouling of ships, at present, there are no international conventions or legally binding international agreements in place that address the invasion risks associated with biological fouling of ships' hulls. Rather, in an effort to heighten awareness and encourage international cooperation for reducing the risks of hull fouling, the IMO Marine Environment Protection Committee has drafted international guidelines for effective antifouling systems, suggested hull husbandry and dry-docking schedules, as well as biofouling management (IMO 2011). Some countries (e.g., Australia, Canada, New Zealand), as well as individual states in the U.S. (Hawaii and California) have put fairly stringent regulations into force, which in some cases require underwater inspections of a ship's hull prior to port entry. Floerl (2014, this volume) describes the broader principles, with examples, of how biofouling management is being connected with risk assement as a means for reducing marine invasions.

\subsection{Vector Management}

The uncertainty associated with invasion prediction speaks to the complex nature of the invasion process. Indeed, there are many opportunities and reasons for invasion failures. As described above, invasion success requires the development of a self-sustaining population once introduced beyond the native range. However, there are many potential filters that can result in invasion failure, even prior to the introduction of non-native propagules. Although ships are important vectors for many marine and estuarine species, there are many other vectors by which species are moved around the world. For example, aquaculture, the aquarium trade, live seafood, and bait trade are examples of important vectors by which biota are transported from one location to another. Indeed, even individual species can be moved and introduced by multiple vectors (Ruiz et al. 2011, Williams et al. 2013), suggesting that coordinated management of vectors, rather than species-specific approaches to invasive species management, will be the most effective approach for reducing marine invasions.

Whatever the vector, an animal, plant, or protozoan must 1) be entrained alive (e.g., into a ballast tank or to the hull or niche space on a 
ship's hull), 2) survive the physical and chemical rigors associated with transport in the vector (e.g., hull foulers must withstand temperature, salinity, food availability, shear stresses, and possible toxicity associated with antifouling paints and coatings), and 3) be introduced to a new environment alive. Once introduced, an organism must then at minimum meet the environmental and biological challenges of the new setting in order to survive and successfully reproduce, if an invasion is to be possible. Each of these junctures in the invasion pathway represents an opportunity to reduce in number or eliminate viable biota being entrained, transported, and introduced to new habitats, including newly accessible regions of the Arctic. Floerl (this volume) describes how risk assessment and other approaches can help with understanding and managing invasion risks associated with ships.

\subsection{Conclusions}

With arctic shipping, exploitation of natural resources, and coastal development all increasing, it seems both urgent and prudent for the international community (the Arctic nations especially) to seek cooperative approaches and agreements for reducing and managing the invasion risks associated with biofouling, ballast water, and other possible vectors of marine species. Employing vector management, rather than species by species approaches, will be the most effective and efficient method for invasion prevention. The vector approach is a philosophy that has guided management and policy of ballast water for over 20 years. As a vector, biofouling of hulls presents additional challenges, and treatment technologies, management approaches, and regulations/law are badly needed. In the face of global climate change, researchers must concentrate their efforts on a fuller understanding of the make-up, structure, and function of "natural" arctic marine ecosystems, as best they can. That said, rather that waiting for a full scientific accounting, we must look to other global regions for lessons on invasion impacts and for insights into how these impacts might be prevented. Whether we choose an "Arctic Manifest Destiny", whereby our drive for expanded economies far outstrips our desire to conserve and protect the Arctic's unique environment, or instead seek the possibility of more sustainable Arctic development, is an open question. 


\subsection{Acknowledgements}

I would like to thank the organizers of the Marine Invasive Species in the Arctic: Management Issues Workshop, Brooks Kaiser, Linda Fernandez, Niels Vestergaard, and Irene Nygaard for their kind invitation to participate and to contribute this chapter. I also wish to extend thanks to Gregory Ruiz, Amanda Reynolds, Ian Davidson, and Oliver Floerl for contributing thoughtful discussions and helpful comments in support of this chapter.

\subsection{References}

AFS (2001). International Convention on the Control of Harmful Anti-Fouling Systems on Ships. International Maritime Organization, London, United Kingdom; www.imo.org

Arctic Council (2009). Arctic Marine Shipping Assessment 2009 Report, 194pp, $2^{\text {nd }}$ printing.

Albert RJ, Lishman JM and JR Saxena (2013). Ballast water regulations and the mover toward concentration-based numeric discharge limits. Ecological Applications 23(2): pp. 289-300.

Amos H (2011). Arctic Treaty With Norway Opens Fields. The Moscow Times. 07 July 2011. http://www.themoscowtimes.com/business/article/arctic-treaty-withnorway-opens-fields/440178.html

Armstrong JL, Boldt JL, Cross AD, Moss JH, Davis ND, Myers KW, ... and LJ Haldorson (2005). Distribution, size, and interannual, seasonal and diel food habits of northern Gulf of Alaska juvenile pink salmon Oncorhynchus gorbuscha. Deep Sea Research Part II: Topical Studies in Oceanography, 52(1): pp. 247-265.

Bulleri F and MG Chapman (2010). The introduction of coastal infrastructure as a driver of change in marine environments. Journal of Applied Ecology, 47(1): 26-35.

Byers JE (2002). Impact of non-indigenous species on natives enhanced by anthropogenic alteration of selection regimes. Oikos, 97(3): pp. 449-458.

Carlton JT (1985). Transoceanic and interoceanic dispersal of coastal marine organisms: the biology of ballast water. Ocean Mar Biol Ann Rev 23: pp. 313-371.

Carlton JT (2001). Introduced species in the U.S. coastal waters: environmental impacts and management priorities. Pew Ocean Commission, Virginia USA.

Carlton JT and JB Geller (1993). Ecological roulette: the global transport of nonindigenous marine organisms. Science 261: pp. 78-82.

Chambers LD, Stokes KR, Walsh FC and RJK Wood (2006). Modern approaches to marine anti-fouling coatings. Surface and Coatings Technology 201: pp. 3642-3652.

Christiansen JS, Mecklenburg CW and OV Karamushko (2014). Arctic marine fishes and their fisheries in light of global change. Global change biology, 20(2): pp. 352-359.

Clark GF and EL Johnston (2005). Manipulating larval supply in the field: a controlled study of marine invisibility. Marine Ecology Progress Series 298: pp. 9-19.

Cranfield HJ, Gordon D, Willan R, Marshall B, Battershill C, Francis M, Nelson W, Glasby C and G Read (1998). Adventive marine species in New Zealand. NIWA technical report No. 34. Hamilton, NIWA: pp. 56. 
Crooks JA, Chan AL and GM Ruiz (2011). Aquatic pollution increases the relative success of invasive species. Biological Invasions, 13(1): pp. 165-176.

Coutts AD and MD Taylor (2004). A preliminary investigation of biosecurity risks associated with biofouling on merchant vessels in New Zealand. New Zealand Journal of Marine and Freshwater Research, 38(2): pp. 215-229.

Davidson IC, Brown CW, Sytsma MD and GM Ruiz (2009). The role of containerships as transfer mechanisms of marine biofouling species. Biofouling, 25(7): pp. 645-655.

de Rivera CE, Steves BP, Fofonoff PW, Hines AH and GM Ruiz (2011). Potential for high-latitude marine invasions along western North America. Diversity and Distributions, 17(6): pp. 1198-1209.

Doney SC, Fabry VJ, Feely RA and JA Kleypas (2009). Ocean acidification: the other $\mathrm{CO}_{2}$ problem. Annual Review Marine Science, 1: pp. 169-192.

Dumont CP, Harris LG and CF Gaymer (2011). Anthropogenic structures as a spatial refuge from predation for the invasive bryozoan Bugula neritina. Marine Ecology Progress Series, 427: pp. 95-103.

Elith J, Phillips SJ, Hastie T, Dudík M, Chee YE and CJ Yates (2011). A statistical explanation of MaxEnt for ecologists. Diversity and Distributions, 17:pp. 43-57.

Elton, C. S. (1958). The ecology of invasions by plants and animals. Methuen, London, 18.

Evers M (2013). Northeast Passage: Russia moves to boost Arctic shipping. Der Spiegel. http://www.spiegel.de/international/world/russia-moves-to-promote-northeastpassage-through-arctic-ocean-a-917824.html

Fofonoff PW, Ruiz GM, Steves B and JT Carlton (2003). In ships or on ships? Mechanisms of transfer and invasion for nonnative species to the coasts of North America In: Ruiz GM and Carlton JT (eds). Invasive species: vectors and management strategies. Island Press, Washington. pp. 152-182.

Fabry VJ, McClintock JB, Mathis JT and JM Grebmeier (2009). Ocean acidification at high latitudes: the bellweather. Oceanography, 22(4): pp. 160-171.

Floerl 0 and GJ Inglis (2003). Boat harbour design can exacerbate hull fouling. Austral Ecology, 28(2): pp. 116-127.

Gautier DL, Bird KJ, Charpentier RR, Grantz A, Houseknecht DW, Klett TR ... and C] Wandrey (2009). Assessment of undiscovered oil and gas in the Arctic. Science, 324(5931): pp. 1175-1179.

Glasby TM, Connell SD, Holloway MG and CL Hewitt (2007). Nonindigenous biota on artificial structures: could habitat creation facilitate biological invasions? Marine Biology, 151(3): pp. 887-895.

Godwin LS and LG Eldredge (2001). South Oahu marine invasions shipping study (SOMISS).

Gollasch S (2002). The Importance of ship hull fouling as a vector of species introductions into the north sea. Biofouling 18(2): pp. 105-121.

Hall-Spencer JM, Rodolfo-Metalpa R, Martin S, Ransome E, Fine M, Turner SM, Rowley SJ, Tedesco D, and MC Buia (2008). Volcanic carbon dioxide vents show ecosystem effects of ocean acidification. Nature, 454(7200): pp. 96-99.

Hewitt CL, Campbell ML, Thresher RE, Martin RB, Boyd S, Cohen BF, Currie DR, Gomon MF, Keough MJ, Lewis JA, Lockett MM, Mays N, McArthur MA, O'Hara TD, Poore GCB Ross DJ, Storey MJ, Watson JE and RS Wilson (2004). Introduced and cryptogenic species in Port Phillp Bay, Victoria, Australia. Marine Biology 144: pp. 183-202.

Hewitt CL, Gollasch S and D Minchin (2009). The vessel as a vector - biofouling, ballast water and sediments. Pp. 117-131 in: Rilov G, Crooks JA (eds) Biological 
Invasions in Marine Ecosystems: Ecological, Management, and Geographic Perspectives. Springer-Verlag Berlin Heidelberg.

(IMO) International Maritime Organization (2011). Annex 26, Resolution MEPC.207(62), 2011 Guidelines for the control and management of ship's biofouling to minimize the transfer of invasive aquatic species, www.imo.org/blast/blastDataHelper.asp?data_id=30766

(IMO) International Maritime Organization (2014). Shipping in polar waters Development of an international code of safety for ships operating in polar waters (Polar Code), www.imo.org/MediaCentre/HotTopics/polar/Pages/default.aspx.

Inglis GJ, Floerl OM Unwin M, Ponder-Sutton A, Seaward K, Kospartov M, Bell A and D Kluza (2010). The biosecurity risks associated with biofouling on international vessels arriving in New Zealand: summary of the patterns and predictors of fouling. MAF Biosecurity New Zealand Technical Paper. Wellington, New Zealand: MAF Biosecurity New Zealand.

IPCC (2007). Climate Change 2007: the physical science basis. contribution of Working Group I to the Fourth Assessment Report of the Intergovernmental Panel on Climate Change. [Meehl GA, Stocker TF, Collins WD, Friedlingstein P, Gaye T, Gregory JM, Kitoh A, Knutti R, Murphy JM, Noda A, Raper SCB, Watterson IG, Weaver AJ and ZC Zhao (eds)] Cambridge University Press, Cambridge, United Kingdom.

IPCC (2013). Summary for Policymakers. In: Climate Change 2013: The Physical Science Basis. Contribution of Working Group I to the Fifth Assessment Report of the Intergovernmental Panel on Climate Change [Stocker, T.F., D. Qin, G.-K. Plattner, M. Tignor, S. K. Allen, J. Boschung, A. Nauels, Y. Xia, V. Bex and P.M. Midgley (eds.)]. Cambridge University Press, Cambridge, United Kingdom and New York, NY, USA.

Johnston EL, Piola RF and GF Clark (2009). The role of propagule pressure in invasion success. Pp. 133-151 in: Rilov G, Crooks JA (eds) Biological Invasions in Marine Ecosystems: Ecological, Management, and Geographic Perspectives. SpringerVerlag Berlin Heidelberg.

Koranyi B (2014). Expanding Arctic ocean to get its own shipping rules. 21 Jan 2014 www.reuters.com/article/2014/01/21/arctic-shippingidUSL3N0KU3Q020140121

Kroeker KJ, Micheli F, Gambi MC and TR Martz (2011). Divergent ecosystem responses within a benthic marine community to ocean acidification. Proceedings of the National Academy of Sciences, 108(35): pp. 14515-14520.

Lawson (2013). Russia opens it maritime arctic. Pp. 297-306 in Zellen BS (ed) (2013). The fast-changing Arctic: Rethinking Arctic security for a warmer world. University of Calgary Press.

Lockwood JL, Cassey P and T Blackburn (2005). The role of propagule pressure in explaining species invasions. Trends Ecology and Evolution 20: pp. 223-228.

McGarrity J and H Gloystein (2013). Northwest Passage crossed by first cargo ship, the Nordic Orion, heralding new era of Arctic commercial activity.

http://news.nationalpost.com/2013/09/27/northwest-passage-crossed-by-firstcargo-ship-the-nordic-orion-heralding-new-era-of-arctic-commercial-activity/

Miller AW, Minton MS and GM Ruiz (2011). Geographic limitations and regional differences in ships' ballast water management to reduce marine invasions in the contiguous United States. BioScience 61(11): pp. 880-887.

Minchin D (2006). The transport and the spread of living aquatic species. In: Davenport J, Davenport JL (eds) The ecology of transportation, managing mobility for the environment. Springer, Berlin Heidelberg New York, pp. 77-97. 
Minton MS, Verling E, Miller AW, Ruiz GM (2005). Reducing propagule supply and coastal invasions via ships: Effects of emerging strategies. Frontiers in Ecology and the Environment 3: 304-308.

[NBIC] National Ballast Information Clearinghouse (2014). http://invasions.si.edu/nbic/

Nehring S (2001). After the TBT era: alternative anti-fouling paints and their ecological risks. Senckenbergiana maritima 31(2): pp. 341-351.

[NSRA] Northern Sea Route Administration (2014). http://www.nsra.ru

[NSRIO] Northern Sea Route Information Office (2014). http://www.arctic-lio.com/

[NRC] National Research Council (1996). Stemming the Tide: Controlling Introductions of Nonindigenous Species by Ships' Ballast Water. National Academy of Sciences.

[NRC] National Research Council (2011). Assessing the Relationship Between Propagule Pressure and Invasion Risk in Ballast Water. National Academy of Sciences.

Orr JC, Fabry VJ, Aumont O, Bopp L, Doney SC, et al. (2005). Anthropogenic ocean acidification over the twenty-first century and its impact on calcifying organisms. Nature 437(7059): pp. 681-686.

Reid PC, Johns DG, Edwards M, Star M, Pouli M and P Snoeijs (2007). A biological consequence of reducing Arctic ice cover: arrival of the Pacific diatom Neodenticula seminae in the North Atlantic for the first time in 800,000 years. Global Change Biology, 13(9): pp. 1910-1921.

Riebesell U, Gattuso JP, Thingstad TF and JJ Middelburg (2013). "Preface" Arctic ocean acidification: pelagic ecosystem and biogeochemical responses during a mesocosm study". Biogeosciences (BG), 10(8): pp. 5619-5626.

Royal Society (2005). Ocean acidification due to increasing carbon dioxide.Policy document 12/05 The Royal Society. 60 p.

Ruiz GM, Fofonoff PW, Carlton JT, Wonham MJ, and AH Hines (2000a). Invasion of coastal marine communities in North America: apparent patterns, processes, and biases. Annual Review of Ecology and Systematics 2000: pp. 481-531.

Ruiz GM, Rawlings TK, Dobbs FC, Drake LA, Mullady T, Huq A and RR Colwell (2000b). Global spread of microorganisms by ships. Nature 408(6808): pp. 49-50.

Ruiz GM and CL Hewitt (2009). Latitudinal patterns of biological invasions in marine ecosystems: a polar perspective. In: Krupnik I, Lang MA and SE Miller (eds) Smithsonian at the poles: contributions to International Polar Year science. Smithsonian Institution Scholarly Press. Washington DC, pp

Ruiz GM, Fofonoff PW, Steves B, Foss SF and SN Shiba (2011). Marine invasion history and vector analysis of California: a hotspot for western North America. Diversity and Distributions, 17(2): pp. 362-373.

Sabine CL, Feely RA, Gruber N, Key RM, Lee K, et al. (2004). The Oceanic Sink for Anthropogenic CO2. Science 305: pp. 367-371.

Sousa WP (1979). Experimental investigations of disturbance and ecological succession in a rocky intertidal algal community. Ecological Monographs, 49(3): 227-254.

Stachowicz JJ, Whitlatch RB and RW Osman (1999). Species diversity and invasion resistance in a marine ecosystem. Science, 286(5444): pp. 1577-1579.

[TGSC] Tschudi Group Shipping Company (2010). http://www.tschudiarctic.com/page/208/Northern_Sea_Route_Project_2010

Valentine JP and CR Johnson (2003). Establishment of the introduced kelp Undaria pinnatifida in Tasmania depends on disturbance to native algal assemblages. Journal of Experimental Marine Biology and Ecology, 295(1): pp. 63-90. 
Verling E, Ruiz GM, Smith LD, Galil B, Miller AW, and KR Murphy (2005). Supply-side invasion ecology: characterizing propagule pressure in coastal ecosystems. Proceedings of the Royal Society B: Biological Sciences, 272(1569): pp. 1249-1257.

Vermeij GJ (1991). Anatomy of an invasion: the trans-Arctic interchange. Paleobiology, 1991: pp. 281-307.

Ware C, Berge J, Sundet JH, Kirkpatrick JB, Coutts ADM, Jelmert A, Olsen SM, Floerl O Wisz MS and IG Alsos (2014). Climate change, non-indigenous species and shipping: assessing the risk of species introduction to a high-Arctic archipelago. Diversity and Distributions 20: pp. 10-19.

Williams SL, Davidson IC, Pasari JR, Ashton GV, Carlton JT, Crafton RE, Fontana RE, Grosholz ED, Miller AW, Ruiz GM and CJ Zabin (2013). Managing Multiple Vectors for Marine Invasions in an Increasingly Connected World. BioScience, 63(12): 952-966.

Wittmann AC and HO Pörtner (2013). Sensitivities of extant animal taxa to ocean acidification. Nature Climate Change, 3(11):pp. 995-1001.

Zellen BS (ed) (2013). The fast-changing Arctic: Rethinking Arctic security for a warmer world. University of Calgary Press. 



\section{Management challenges and opportunities for marine biosecurity in the Arctic}

Oliver Floerl, SINTEF Fisheries and Aquaculture, Trondheim, Norway

\subsection{Biosecurity management and its importance}

Invasive species are one of the most serious threats to the diversity and integrity of marine ecosystems (Carlton 2001). Once established and undergoing spread, they can be impossible to eradicate and their impacts may be irreversible (Mack et al. 2000).

To protect themselves against invasive species, some countries have developed so-called biosecurity systems (Hewitt and Campbell 2007). Different definitions are used for the term biosecurity; a useful one is that of New Zealand:

Biosecurity is the exclusion, eradication or effective management of risks posed by pests and diseases to the economy, environment and human health.

(Biosecurity Council 2003)

The organisation of biosecurity measures into a defined and regulated system is important. In today's world of trade and transport a multitude of pathways, mechanisms and vectors are able to translocate a wide range of organisms or their propagules. Managing these complex, dynamic and often unpredictable processes is very difficult and the consequences of loopholes can be substantial. The development of an effective biosecurity system requires significant commitment but can offer immense long-term benefits.

The Arctic region is undergoing rapid change, both environmentally and economically. Shiping traffic already connects Arctic ports to a considerable range of other global regions (Ware et al. 2013) and this is expected to increase further (Miller 2014, this volume), conceivably with a concomitant increase in invasion risk (Verling et al. 2005, Drake and 
Lodge 2007). To protect themselves against the impacts of future invaders, Arctic nations now have an opportunity to learn from the experiences of years of biosecurity science and management undertaken at lower latitudes, experience that includes both successes and failures.

This chapter will discuss some of the key elements of marine biosecurity management, drawing on case studies and experiences from a range of maritime nations, predominantly New Zealand and Australia. The purpose of this chapter is not a detailed description of entire biosecurity systems (it takes most countries years to develop these) but, rather, to provide a concise and informal overview of some of their main components relating to the prevention or mitigation of unintentional species introductions. Given this specific focus, no consideration is given here to two nevertheless very important components of national biosecurity systems: (1) measures related to intentional species introductions for economic or recreational activities, and (2) the requirement for national biosecurity systems to provide sanitary and phytosanitary assurances to trading partners and to avoid protectionist trade measures (WTO 1995, Hewitt and Campbell 2007).

\subsection{A simple framework for effective biosecurity management}

A primary requirement for meaningful and effective biosecurity management is that the biosecurity risks to a country or region be understood and, as far as possible, quantified. This knowledge should then serve as a foundation for management strategies, including the prevention of non-native species introductions (pre-border management) and efforts for eradication or management of introduced or established species (post-border management). Figure 1 illustrates this process and Box 1 provides information on key terms used in this chapter.

\subsubsection{Understanding risk}

As described above and in Miller (2014, this volume), there are numerous pathways and vectors that could transport non-native species and propagules to and within the arctic region. What is the relative risk of each pathway and vector? Are there particular non-native species that are established in trading ports that should be prevented from reaching the Arctic? Which arctic areas are most sensitive and which are at highest risk of invasion? These are some of the questions biosecurity manag- 
ers should ask and strive to answer. A useful approach for this is risk assessment, a family of tools and techniques that determine the likelihood and consequences of undesired events (Hayes 2003, Drake 2005). Both quantitative and qualitative risk assessment tools are available. Risk assessment can be a useful and objective aid for understanding the relative risk of different pathways, vectors, locations, species, etc., and should underpin decision-making, prioritisation and resource allocation. Risk assessment can also form the basis of measures for managing biosecurity risks pre- and post-border (see sections below).

New Zealand and Australia are two maritime nations that have invested considerable effort into quantifying and understanding the marine biosecurity risks that they are exposed to. For example, in 2004 the New Zealand government commissioned the sampling of nearly 500 international vessels (including merchant, recreational and fishing vessels, as well as towed barges) to determine the significance of vessel biofouling as an introduction vector for non-native species to New Zealand and the relative risk posed by different vessel types (Cawthron Institute 2010, Inglis et al. 2010, Piola and Conwell 2010, Bell et al. 2011). The role of New Zealand's domestic shipping network was also examined (Hayden et al. 2008). In a parallel effort, the New Zealand government commissioned biological baseline surveys in the country's main shipping ports (selected by risk assessment) to create an inventory of established non-native species and their likely mode of introduction (Inglis 2001, Inglis et al. 2007). These exercises considerably increased the understanding of the biosecurity risks that New Zealand is subject to and, amongst other things, formed the basis for proposed hygiene standards for international vessel arrivals to New Zealand. Related efforts in Australia involved, for example, comparisons of biofouling and ballast water as introduction mechanisms and an examination of the biosecurity risks posed by the aquarium and ornamental fish industry (AMOG Consulting 2002, Hewitt and Campbell 2008, Morrisey et al. 2011). These activities are selected examples of a more comprehensive and on-going effort to understand sources of marine biosecurity risk. They illustrate how a strong motivation to understand risk has brought New Zealand and Australia into good positions for developing effective management strategies. 
Figure 1: Framework for understanding and managing biosecurity risk to a nation or region

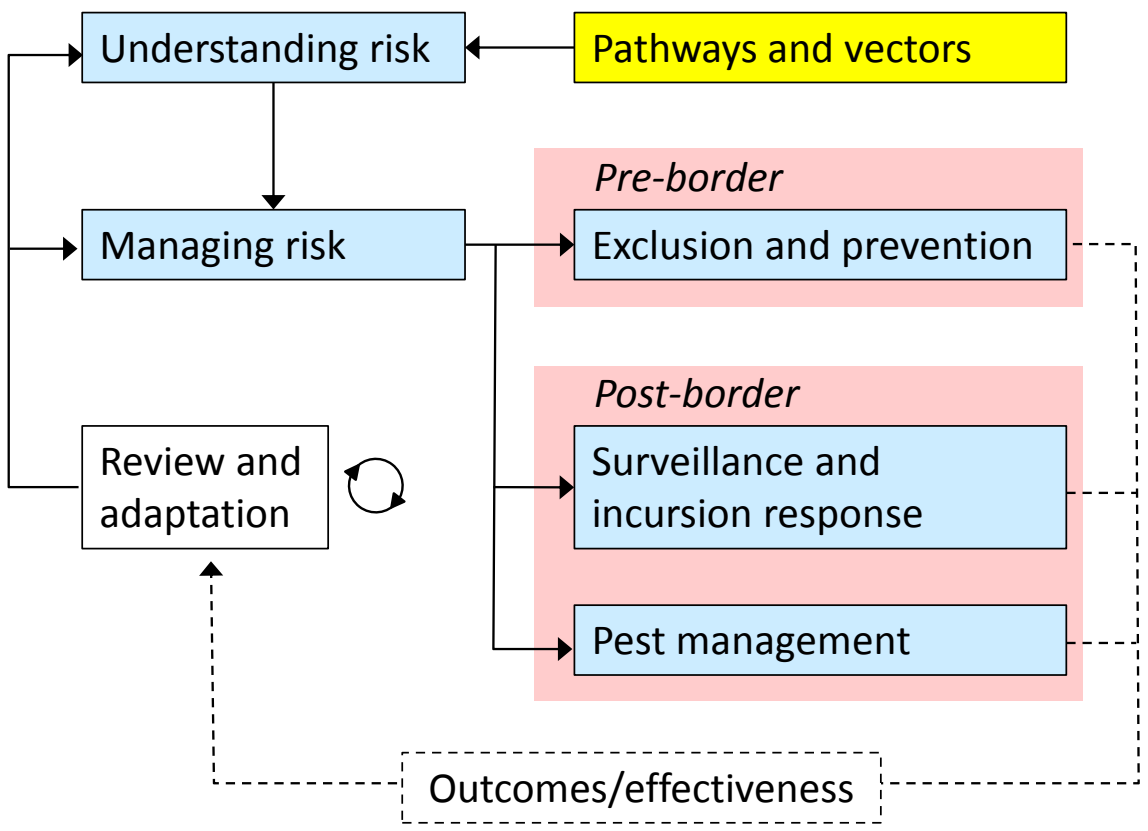

Box 1: Terminology for biosecurity management

- Vectors

Means by which non-native species can be introduced to or spread within the arctic region (e.g. ballast water in merchant vessels).

- Pre-border biosecurity management

Actions taken to prevent the entry of non-native species and their propagules into the Arctic. For example, ballast water management, biofouling standards for vessel hulls, inspections, etc.

- Post-border biosecurity management

Actions taken to manage non-native species that have been introduced or become established within the Arctic (i.e. where pre-border effects were absent or failed).

- Incursion response

A set of immediate actions taken once a non-native species is detected. Incursion response can include delimitation surveys, vector assessments and feasibility studies (as well as other actions).

- Pest management

Management of established non-native populations. Pest management can involve eradication campaigns, population control or preventing further spread (as well as other actions). 


\subsubsection{Managing risk}

\section{Pre-border}

Understanding the types of biosecurity risks that a region is exposed to is essential for the development of effective strategies and measures to manage these risks. A key component of risk management should be pre-border efforts aimed at excluding non-native species and minimising the likelihood of introductions (Fig. 1). This is because attempts to eradicate or otherwise control established non-native marine populations are generally expensive and stand limited chances of success (Bax et al. 2001, Thresher and Kuris 2004, Bax et al. 2006).

An example of a common pre-border effort is the ballast water management that many coastal nations (e.g. New Zealand, Australia, Canada and others) require international vessels to undertake prior to entering coastal waters (BWM 2005, Hewitt and Campbell 2007, Miller 2014, this volume). In comparison, biofouling is a largely unmanaged vector. Proposed guidelines for minimising biofouling risks from shipping have recently been released by the International Maritime Organization (IMO 2011), however, and several countries have also developed their own requirements. Such requirements can be based on different principles. For example, New Zealand has released a draft Import Health Standard (IHS) that, once in force, will require international vessel arrivals to arrive with hulls free of macroscopic biofouling organisms of any kind (MAF Biosecurity New Zealand 2010a, b). In contrast, Australia has taken a species-specific approach. Using a risk assessment process, a list of "species of concern" was developed comprising species that could cause significant economic or ecological impacts if established in Australian waters. Some states, in particular Western Australia, require international vessels to be demonstrably free of these species (Government of Western Australia 2013).

The best way for vessels to reduce their likelihood of transporting non-native biofouling species is to adopt effective hull maintenance schedules that ensure clean hull surfaces. Such practices include regular dry-docking and antifouling coating renewal, or acceptable forms of inwater hull cleaning. Both New Zealand and Australia provide guidance on these practices for a range of vessel types and industries (Commonwealth Government of Australia 2013, MPI 2013). Another option is the use of regular hull inspections to assess biosecurity risk, either for general biofouling presence or abundance, or for target species (Floerl et al. 2010). Such inspections can be undertaken pre-voyage, at a vessel's departure port, to enable its operators to carry out appropriate action prior to sailing, if required. Some degree of vector risk as- 
sessment can also be undertaken based on predictive models built from hull inspection, maintenance and travel data of an appropriate number of vessels. However, the predictive power of such models can be limited for a range of reasons (Inglis et al. 2010).

\section{Post-border}

Effective pre-border risk management can considerably reduce biosecurity risk but it can not prevent it entirely. At times pre-border systems fail and non-native species are introduced and become established. Welldesigned post-border intervention measures can then help to minimise their potential impacts (Fig. 1). A main aim should be to detect new populations of non-native species while they are small and localised, before they have been able to widely disperse to other locations. New Zealand is using target surveillance (surveys aimed at detecting a set of particular target species) to achieve this for its marine environments. Seasonal surveys for a set of high-risk non-native species are carried out in main shipping ports, marinas and harbours, using sampling methods appropriate for detecting these species (Inglis et al. 2006). On several occasions these surveys have resulted in the detection of established populations of target species, most notably an incursion of the Mediterranean fanworm Sabella spallanzanii in the port of Lyttelton (Read et al. 2011).

To warrant the effort and resources spent on surveillance for early detection of non-native species, systems, strategies and resources for immediate incursion response must be put in place. Incursion response might involve delimitation surveys to assess the size, distribution and demography of newly-detected non-native populations (Gust et al. 2006, Gust et al. 2008a). Prompt, rigorous and adequately resourced incursion response was a critical determinant for the successful eradication of the blackstriped mussel Mytilopsis sallei from an Australian marina shortly after its detection (Hewitt and Campbell 2007). Authorities tasked with biosecurity management should strive to develop incursion response plans based either on target species or habitats at risk of invasion. Incursion response plans should comprise information on the specific objectives of response activities, sampling approaches, decision points, lines of communication and agency responsibilities.

The result of incursion response measures will help management authorities decide whether and in what form "pest management" is feasible (Fig. 1). Pest management measures may involve attempts to eradicate a non-native species from a location or region, to control its population size or density, or to limit its further spread (Culver and Kuris 2000, Miller et al. 2004, Gust et al. 2008b, Atalah et al. 2013). A critical requirement for pest management, particularly eradication attempts, is 
ongoing monitoring of the distribution and demography of targeted populations to ensure pest management efforts fulfil their objectives. Ineffective or no monitoring at all can seriously compromise the resources invested in pest management (Simberloff 2003). Indeed, the outcomes and effectiveness of all pre- and post-border measures and strategies should be monitored and reviewed on a regular basis to enable adaptation and improvement as necessary (Fig. 1).

\subsection{Challenges and opportunities for the Arctic region}

Most global coastal ports and harbours are connected via an intricate and effective transport network. The commercial shipping network, for example, is far more efficient at connecting any two global ports with each another than the global aviation network is with connecting airports (Kaluza et al. 2010). Arctic ports are already frequented by vessels arriving from a wide range of global destinations and regional vessel traffic is going to increase (Miller 2014, this volume, Ware et al. 2014). Although the development of an effective regional biosecurity system will present considerable challenges, it would yield significant environmental and economical benefits. Its success will be maximised if the following criteria can be achieved:

- A regional biosecurity system should be based on common goals shared among all Arctic nations. Ideally these common goals should be formalised and anchored in a regulatory framework, such as New Zealand's Biosecurity Act (1993) and Biosecurity Strategy (Biosecurity Council 2003).

- All pathways and vectors need to be identified and their relative risks assessed, enabling development of effective risk management strategies (Fig. 1).

- Strong global and regional relationships across regulatory authorities and industries should be developed and maintained to identify emerging risks (vectors, pathways or species).

- Sufficient capability and resources must be available to ensure: (i) up-to-date risk assessments, (ii) effective and rapid incursion response, and (iii) effective pest management.

- There should be clarity about the roles and responsibilities of all levels of the biosecurity system (e.g. local, regional, national regional organisations), and effective communication and information-sharing. 
- Effective education and awareness programmes need to be available for the public, industry and other stakeholders to ensure compliance with regulations and best-practice guidance;

- There should be some level of enforcement of key aspects of the biosecurity system (e.g. mandatory ballast water management, etc.).

- All levels of planning, risk assessment, decision-making and policy development should be underpinned by independent and peerreviewed scientific advice to ensure management actions are objective and defensible.

- There needs to be a culture of continuous improvement at all levels of a biosecurity system, including the various agencies and individuals that comprise it.

Biosecurity management can serve to protect the natural and historic heritage of the Arctic region, and help safeguard the integrity of its marine ecosystems and the human cultures that depend on them. While the provision of effective biosecurity for a vast, remote and climatically extreme multi-national region presents considerable challenges, the Arctic and its member states have the opportunity to build upon insights gained during decades of biosecurity management at lower latitudes. This unique opportunity should be seized to maximise protection of this region from the impacts of invasive species.

\subsection{Acknowledgements}

I thank the organisers of the workshop "Marine invasive species in the Arctic: Management issues" at the University of Southern Denmark (SDU) for inviting me to the workshop and to contribute this chapter. Thanks are also due to my previous colleagues, clients and collaborators in New Zealand and Australia where I made most of the insights described here. I particularly thank Ashley Coutts, Whitman Miller and Lisa Peacock for discussions on the topics covered in this chapter and for providing feedback on a draft version. 


\subsection{References}

AMOG Consulting (2002). Hull fouling as a vector for the translocation of marine organisms. Phase I: Hull fouling research. Ballast Water Research Series, Report No. 14. Department of Agriculture, Fisheries and Forestry, Canberra, pp. 142.

Atalah, J., Bennett, H., Hopkins, G. A. and Forrest, B. M. (2013). Evaluation of the sea anemone Anthothoe albocincta as an augmentative biocontrol agent for biofouling on artificial structures. Biofouling, Vol. 29, pp. 559-571.

Bax, N., Carlton, J. T., Mathews-Amos, A., Haedrich, R. L., Howarth, F. G., Purcell, J. E., Rieser, A. and Gray, A. (2001). The control of biological invasions in the world's oceans. Conservation Biology, Vol. 15, pp. 1234-1246.

Bax, N., Dunstan, P., Gunaskera, R., Patil, J. and Sutton, C. (2006). Evaluation of national control plan management options for the north pacific seastar Asterias amurensis. Natural Heritage Trust, Canberra.

Bell, A., Phillips, S., Georgiades, E., Kluza, D. and Denny, C. (2011). Risk Analysis: Vessel Biofouling. Policy and Risk Directorate, MAF Biosecurity New Zealand.,Wellington, pp. 155.

Biosecurity Council (2003): Tiakina Aotearoa: Protect New Zealand. The Biosecurity Strategy for New Zealand (www.maf.govt.nz/biosecurity-strategy). Biosecurity Council. , Wellington, $67 \mathrm{pp}$.

BWM (2005): International Convention on the Control and Management of Ship's Ballast Water and Sediments. International Maritime Organization, London. www.imo.org

Carlton, J. T. (2001): Introduced species in U.S. coastal waters: environmental impacts and management priorities. Pew Oceans Commission, Arlington, 29 pp.

Cawthron Institute (2010): Vessel biofouling as a vector for the introduction of nonindigenous marine species to New Zealand: Slow-moving barges and oil platforms. Report prepared for MAF Biosecurity New Zealand Clearance Directorate, Wellington, $40 \mathrm{pp}$.

Commonwealth Government of Australia (2013): Anti-fouling and in-water cleaning guidelines. Department of Agriculture, Fisheries and Forestry and Department of Sustainability, Environment, Water, Population and Communities and New Zealand Ministry for Primary Industries, Canberra, $22 \mathrm{pp}$.

Culver, C. and Kuris, A. (2000): The Apparent Eradication of a Locally Established Introduced Marine Pest. Biological Invasions, Vol. 2, pp. 245-253.

Drake, J. M. (2005): Risk analysis for invasive species and emerging infectious diseases: Concepts and applications. American Midland Naturalist, Vol. 153, pp. 4-19.

Drake, J. M., and Lodge, D. M. (2007): Hull fouling is a risk factor for intercontinental species exchange in aquatic ecosystems. Aquatic Invasions, Vol. 2, pp. 121-131.

Floerl, O., Wilkens, S. and Inglis, G. (2010): Development of a Template for Vessel Hull Inspections and Assessment of Biosecurity Risks to the Kermadec and sub-Antarctic Islands Regions. Report prepared for Department of Conservation. National Institute of Water and Atmospheric Research, Christchurch, 55 pp.

Government of Western Australia (2013): Western Australian marine pest management guidelines. Western Australia Department of Fisheries, Perth, 2 pp.

Gust, N., Inglis, G., Floerl, O., Peacock, L., Denny, C. and Forrest, B. (2008a): Assessment of population management options for Styela clava. MAF Biosecurity New Zealand Technical Paper No: 2009/04, Wellington, 228 pp. 
Gust, N., Inglis, G. , Peacock, L., Miller, S., Floerl, O., Hayden, B., Fitridge, I., Hurren, H. and Johnston, O. (2006): Rapid nationwide delimitation surveys for Styela clava. NIWA Client Report CHC2006-24, prepared for MAF Biosecurity New Zealand. Christchurch, $81 \mathrm{pp}$.

Hayden, B. J., Unwin, M., Roulston, H., Peacock, L., Floerl, O., Kospartov, M. and Seaward, K. (2008): Vessel Movements within New Zealand: Evaluation of vessel movements from the 24 ports and marinas surveyed through the port baseline survey programmes. NIWA Technical Report prepared for MAF Biosecurity New Zealand.

Hayes, K. R. (2003): Biosecurity and the role of risk assessment. Pages 382-414 in: G. Ruiz and J. T. Carlton, editors. Invasive species: vectors and management strategies. Island Press, Washington.

Hewitt, C. L. and Campbell, M. L. (2007): Mechanisms for the prevention of marine bioinvasions for better biosecurity. Marine Pollution Bulletin, Vol. 55, pp. 395-401.

Hewitt, C. L. and Campbell, M. L. (2008): Assessment of relative contribution of vectors to the introduction and translocation of marine invasive species. Report for the Department of Agriculture, Fisheries and Forestry. National Centre for Marine Conservation \& Resource Sustainability, University of Tasmania, Launceston, $45 \mathrm{pp}$.

IMO (2011): Guidelines for the control and management of ship's biofouling to minimize the transfer of invasive aquatic species (Annex 26, Resolution MEPC.207(62)). (www.imo.org/blast/blastDataHelper.asp?data_id=30766). International Maritime Organization, London.

Inglis, G. J. (2001): Criteria for identifying and selecting high value locations and locations at risk of invasion by exotic marine organisms in New Zealand. NIWA Client Report for New Zealand Ministry of Fisheries, Wellington, $44 \mathrm{pp}$.

Inglis, G. J., Floerl, O., Ahyong, S. T., Cox, S. L., Unwin, M., Ponder-Sutton, A., Seaward, K., Kospartov, M., Read, G., Gordon, D., Hosie, A., Nelson, W., D’Archino, R., Bell, A. and Kluza, D. (2010): The Biosecurity Risks Associated with Biofouling on International Vessels Arriving in New Zealand: Summary of the patterns and predictors of fouling. NIWA Client Report prepared for MAF Biosecurity New Zealand, Wellington, $182 \mathrm{pp}$.

Inglis, G. J., Hurren, H., Gust, N., Oldman, J., Fitridge, I., Floerl, O. and Hayden, B. J. (2006): Surveillance design for early detection of unwanted exotic marine organisms in New Zealand. NIWA Client Report, For New Zealand Ministry of Fisheries, Christchurch, $47 \mathrm{pp}$.

Inglis, G. J., Kospartov, M., Fitridge, I., Gust, N., Floerl, O., Fenwick, G. D. and Hayden, B. J. (2007): Port Baseline Surveys for Introduced Marine Species: Summary of results. NIWA Client Report prepared for MAF Biosecurity New Zealand Post-Clearance Directorate, Christchurch, 109 pp.

Kaluza, P., Kolzsch, A., Gastner, M. T. and Blasius, B. (2010): The complex network of global cargo ship movements. Journal of the Royal Society Interface, Vol 7, pp. 1093-1103.

Mack, R., Simberloff, D., Lonsdale, W., Evans, H., Clout, M. and Bazzaz, F. (2000): Biotic invasions: causes, epidemiology, global consequences and control. Ecological Applications, Vol. 10, pp. 689-710.

MAF Biosecurity New Zealand (2010a): Draft guidance document in support of the Import Health Standard for Vessel biofouling. Ministry of Agriculture and Forestry, Wellington, $12 \mathrm{pp}$.

MAF Biosecurity New Zealand (2010b): Import Health Standard for Vessel Biofouling (Draft, BNZ-STD-BIOFOUL). Ministry of Agriculture and Forestry, Wellington, 3 pp. 
Miller, A. W., Chang, A. L., Cosentino-Manning, N. and Ruiz, G. M. (2004): A new record and eradication of the Northern Atlantic alga Ascophyllum nodosum (Phaeophyceae) from San Francisco Bay, California, USA. Journal of Phycology, Vol. 40, pp. 1028-1031.

Morrisey, D., Inglis, G., Neil, K., Bradley, A. and Fitridge, I. (2011): Characterization of the marine aquarium trade and management of associated marine pests in Australia, a country with stringent import biosecurity regulation. Environmental Conservation, Vol. 38, pp. 89-100.

MPI (2013): Clean Boats, Living Seas. (http://www.biosecurity.govt.nz/video/ cleanboats-living-seas-1). New Zealand Ministry of Primary Industries, Wellington.

Piola, R. F. and Conwell, C. (2010): Vessel biofouling as a vector for the introduction of nonindigenous marine species to New Zealand: Fishing vessels. MAF Biosecurity New Zealand Technical Paper 2010/11. Cawthron Institute, Nelson. 57 pp.

Read, G. B., Inglis, G., Stratford, P. and Ahyong, S. T. (2011): Arrival of the alien fanworm Sabella spallanzanii (Gmelin, 1791) (Polychaeta: Sabellidae) in two New Zealand harbours. Aquatic Invasions, Vol. 6, pp. 273-279.

Simberloff, D. (2003): Eradication-preventing invasions at the outset. Weed Science, Vol. 51, pp. 247-253.

Thresher, R. E., and Kuris, A. M. (2004): Options for managing invasive marine species. Biological Invasions, Vol. 6, pp. 295-300.

Verling, E., Ruiz, G. M., Smith, L. D., Galil, B., Miller, A. W. and Murphy, K. R. (2005): Supply-side invasion ecology: Characterizing propagule pressure in coastal ecosystems. Proceedings of the Royal Society - Biological Sciences (Series B), Vol. 272, pp. 1249-1256.

Ware, C., Berge, J., Sundet, J. H., Kirkpatrick, J. B., Coutts, A. D. M., Jelmert, A., Olsen, S. M., Floerl, O., Wisz, M. S. and Alsos, I. G. (2014): Climate change, non-indigenous species and shipping: assessing the risk of species introduction to a high-Arctic archipelago. Diversity and Distributions, Vol. 20, pp. 10-19.

WTO (1995): The application of Sanitary and Phytosanitary Measures.

(http://www.wto.org/english/docs_e/legal_e/15-sps.pdf). World Trade Organization, Geneva. 

Section 3:

Current Invasive Species Problems in the Arctic: Case Studies 



\section{The red king crab (Paralithodes camschaticus) in the Barents Sea}

Jan H. Sundet, Institute of Marine Research, Tromsø, Norway.

\subsection{Summary}

The red king crab is deliberately introduced and has spread to most parts of the southern Barents Sea, from about $36^{\circ} \mathrm{E}$ to about $26^{\circ} \mathrm{E}$. It is found more off shore in Russian than in Norwegian waters. The biology of this crab is similar to what is found in native areas; hatching larvae and spawning takes place in shallow waters in spring, and the larvae stay pelagic up to 60 days before it settles. Growth is faster and maturation size larger in Norwegian waters than in native areas, whilst diet is the same. Main prey is different benthic organisms. This feeding behavior cause serious impact on receptive benthic communities in areas with high crab abundance.

In Norway, the red king crab management regime has two goals; to maintain a long term quota regulated fishery within a limited area, and to limit further spread of the crab beyond this area.

\subsection{Introduction history}

The red king crab was deliberately introduced to the Barents Sea by Russian scientists at several occasions during the 1960s and 1970s (Orlov and Ivanov 1977). The overall aim of the introduction was to create a new fishery on a new valuable fishing resource, and Russian and Norwegian scientists verified that the introduction was a "success" in a paper in 1995 (Kuzmin et al. 1996).

During the first years of appearance the red king crab was mainly regarded as a "blessing" for the fishing industry, both in Russia and in Norway. Only a few expressed any concerns about the crab being a non- 
native species, posing threats to the receptive ecosystem. This opinion of the crab, however, changed sometime just after the new millennium, particularly in Norway. The new apprehension has affected also the way this species is managed in Norway, but seems to have had no impact on the king crab management in Russia.

\subsection{Biology of the red king crab}

\subsubsection{Spread and abundance}

Red king crabs were recorded for the first time in Norwegian waters in 1977, but it was not until the beginning of the 1990s that they became abundant in limited areas close to the Russian border (Nilssen 2003). At that time the crab had occupied most of coastal areas on the Kola peninsula from about $36^{\circ} \mathrm{E}$ to the Norwegian border. In Norwegian waters the crab spread continuously westwards within near coastal waters. The spreading appeared to be more or less discontinuous in the way that small aggregations of crabs popped up at small localities in inner part of fjords further west, with no recordings in the areas back to the source population.

It is difficult to locate the front of the king crab distribution in Norwegian waters today, but we assume that the crab has moved by itself at least to areas around Troms $\varnothing$ in west, and to distances of about 12-15 nm off shore (Figure 1). 
Figure 1: Approximate distribution of the red king crab in the Barents Sea. Red asterisks indicate catch sites of single crabs

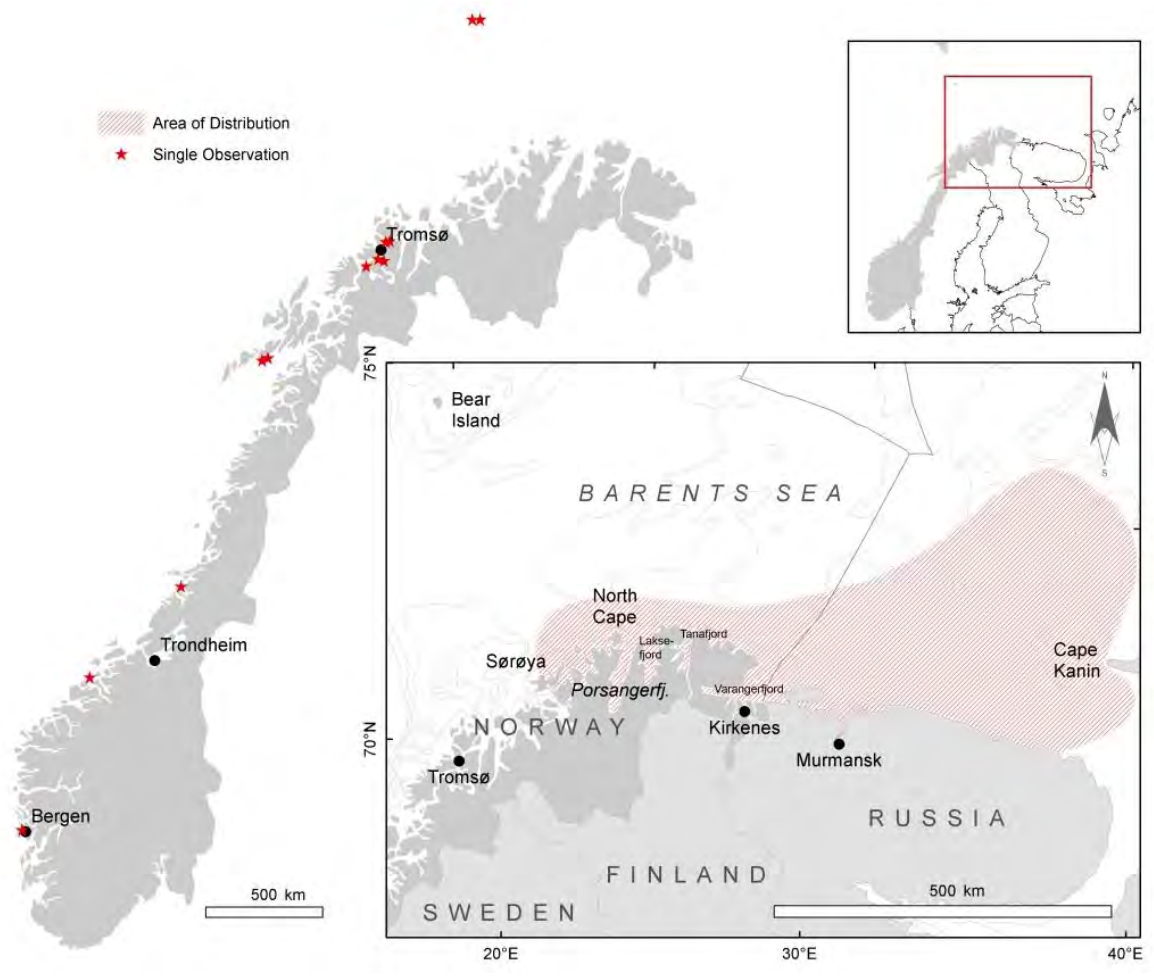

The current Norwegian management system (see page 58) results in a low population density and consequently a limited spreading rate west of $26^{\circ} \mathrm{E}$. There are very few observations of red king crabs far off shore in the Norwegian part of the Barents Sea, while the crab seem to disperse more into open sea waters in the Russian part. Here, the highest densities are found some $30-50 \mathrm{~nm}$ ashore where the largest fishery harvest is also taking place (Figure 1).

There were no estimates of the total stock indices in Norwegian waters until 2002. Therefore, legal male stock indices could be regarded as a proxy for the total stock. As the crab spread to new areas further west, the population was followed up with stock estimates in new areas continuously. Therefore, the presented stock indexes of legal male crabs for the first period were only for Varangerfjorden; followed by Tanafjorden and the area Østhavet in 2003, and Laksefjorden in 2004 (Figure 1). The complete crab stock in the Norwegian commercial area (see pages 56-7) was estimated for the first time in 2008. 


\subsubsection{Demography}

As the general picture of unexploited accumulated fish stocks, the first catches of red king crabs in newly established areas in Finnmark were characterized by the presence of many large individuals of both sexes. Abundant year classes, visualized as peaks in the annual size distribution were also commonly observed during the "virgin" period before the exploitation rate increased largely after about 2000. Juvenile crabs, smaller than about $50 \mathrm{~mm}$ carapace length, are sparsely represented in our samples all years, due to the crab life history. Juvenile crabs inhabit shallow areas all year around, and start descending to deeper areas as they increase in size. Therefore, it is not possible to establish reliable stock indices of this part of the crab stock.

After the introduction of a high exploitation rate in the Norwegian red king crab fishery, it seems that abundant year classes appear less frequently, and that recruitment has become more stable at a low level.

\subsubsection{Growth and reproduction}

Growth in the red king crab, as in all crustaceans, consists of two parameters; size increment at each molt, and the frequency of molting. Female red king crabs always molt before spawning of eggs, while molting in adult male crabs is more irregular (McCaughran and Powell 1977). Juvenile red king crabs may molt on several occasions during a year and the molting frequency becomes once a year as they grow to mature specimens (Donaldson and Byersdorfer 2005). The red king crab in Norwegian waters seems to grow somewhat faster than crabs in their native areas, but this may have changed in recent years due to less available food (Nilssen and Sundet 2006, Oug et al. 2011).

Size at maturity for both male and female red king crabs seems to be about $110 \mathrm{~mm}$ carapace length (Rafter et al. 1996, Hjelset et al. 2009). This is larger than in the red king crabs native areas. Hatching, spawning and mating takes place at shallow waters $(<20 \mathrm{~m})$ in spring where high numbers of male and female crabs aggregate for 2-3 months (Powell and Nickerson 1965).

Each mature female crab spawns commonly 100-300 thousand eggs every year which are fertilized, dependent on crab size (Hjelset et al. 2012), and an average female performs approximately 10-15 spawning seasons. This means that the red king crab as a species has a very high reproductive potential, which may be one of its major success factors regarding the adaptation to the new ecosystem in the Barents Sea. There is, however, observed a significant reduction in the potential egg produc- 
tion in the Norwegian red king crab stock in recent years, probably due to the fishery on large males only (Hjelset 2014).

The larval phase in the red king crab life history may be of crucial importance when assessing spread of the species. The crab larvae may be pelagic for up to 60 days, dependent on environmental temperature, and may therefore be spread by currents (Pedersen et al. 2006). Unpublished results also show that the red king crab larvae are able to survive higher temperatures than earlier anticipated (Sparboe unpubl.). This may indicate that the crab could spread to a wider area in the northeast Atlantic in the future.

\subsubsection{Diet and feeding}

Several studies show that the red king crab feed on numerous prey categories, both in its native areas as well in the Barents Sea (Feder and Jewett 1981, Sundet et al. 2000). These finding may lead to the conclusion that the crab is a generalist feeder (Falk-Petersen et al. 2011), but other studies reveal that the crab prefers and remove large individuals of invertebrates such as bivalves, echinoderms and siphunculids (Haugan 2004, Oug et al. 2011). Prey preference studies based on stomach content analysis may, however, be difficult to interpret since for some prey groups only soft parts of the animals are ingested (e.g. large mussels), while for other groups (small mussels and worms) hard parts enter the digestive system (Jørgensen 2005, Jørgensen and Primicerio 2007). This entails that the presence of some prey groups in the diet may be overestimated.

\subsubsection{Fishery}

The major fishery for the red king crab has taken place in the Bering Sea and the northern Pacific, where the exploitation of the crab can be dated back to 1930 (Otto 1986). The fishery in this part of the world is mainly carried out by the USA, Russia and Japan, where the US annual maximum catches amounted to about 65 thousand tons in 1980 (Otto op cit). Since then the catches have gone down dramatically, and the fishery in Alaskan water closed for several seasons during the 1980s and 1990s. Total catch in recent years has been 3-10 thousand tons in Alaskan waters.

The red king crab fishery in the Barents Sea started as a small experimental fishery agreed upon by Norway and Russia in 1994. This fishery lasted as an experimental fishery in Norway until 2002 and in Russia until 2004, when they were transformed to more regular commercial 
fisheries. The catch quotas were small in both countries during the first years, but increased significantly at the onset of the commercial fishery (Figure 2). The annual value of the total landings of red king crab has varied greatly; this is mostly due to varying market prices (Figure 2).

Figure 2: Landings of red king crab in quota regulated area and free fishing area in the Norwegian coastal waters off Finnmark

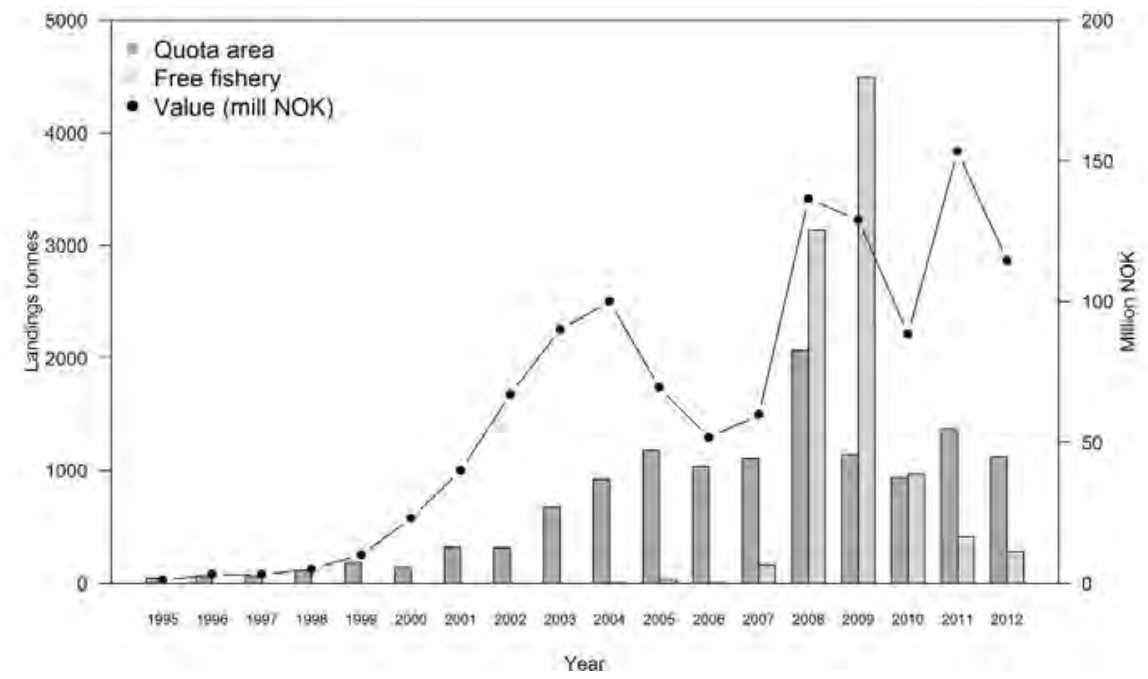

Stippled line show value of annual landings in million NOK.

Only pots are allowed in the red king crab fishery both in Russia and in Norway, although the crab fishery is very different in the two economic zones. In Russia the red king crab fishery is performed by large ( $>60 \mathrm{~m}$ ) vessels operating many pots, whilst in Norway this fishery is reserved for small vessels operating only a few $(<30)$ pots in near coastal waters. In Norway, only those fishermen experiencing bycatch problems with the red king crab in other fisheries (gillnet, long line etc) are given license and annual catch quotas. This entails that the majority of the fishers catching the red king crab in Norway lives in Finnmark County, due to the distribution pattern of the crab.

\subsection{Impact on ecosystem and fisheries}

Early studies on the red king crab stomach content indicate that this species could affect the benthic ecosystem since the majority of the prey organisms were benthic living species (Sundet et al. 2000). Revealing any such impacts was however, challenging due to lack of knowledge of 
the recipient benthic ecosystem before the red king crab appeared in high abundance in Norwegian waters. The lack of "pre-introduction" base line studies of the benthic fauna may be explained by the low focus on introduced species among leading scientists at that time in Norway. Fortunately, a study of the benthic fauna with a different goal, carried out in Varangerfjord in the mid 1990s, came to our knowledge and could work as a comparable study of the impact of the red king crab. Benthic sampling stations from the early 1990s were re-sampled in 2007 and revealed serious changes in the benthic ecosystems where the red king crab have been present in high densities for a long period (Oug et al. 2011). The major changes caused by the crab were a significant reduction in both number of species, standing biomass and that all large specimens of bivalves, echinoderms and polychaetes were absent. In addition there were indications of a reduction in bottom sediment quality due to the feeding activity of the crab.

The impact of the red king crab on the local fishery activity was obvious as soon as the red king crab entered Norwegian waters in some amount. The crab caused problems by entangling gillnets and by removing bait from long-lines (Sundet and Hjelset 2002).

\subsection{Management}

The red king crab occupied a particular role in the Barents Sea fauna when it appeared in high abundances in the early 1990s. Before this time, there was no crab species that abundant, and in addition being a valuable fishing resource. The consciousness among marine scientists and fishery managers about non-native species was also low in these early years. Therefore, the red king crab was mainly regarded as a valuable species for fishery during the first years. It was much later (around 2000) recognized as an unwanted species as well, and these attitudes also mirrored the management actions been taken. During the experimental fishery period the red king crab was regarded as a shared stock between Norway and Russia, and the annual quotas were set by the Mixed Norwegian-Russian Fishery Commission. The management in this period was mainly based upon a 3-S regime (Size, Sex and Season), in addition to depth limitation for fishing activities. The exploitation rate was low during this period allowing the red king crab stock to increase and spread to new areas. This period of joint management with Russia lasted until 2007, when the Commission agreed on a separate national management. In Norway, the Ministry of Fisheries and Coastal affairs 
launched a whitepaper to the Parliament where official management goals were presented for the first time (Anon 2007). At that time one was aware that this new species also had some devastating effects on the recipient ecosystem as well as the performance of local gill net fishery. The main aim of the Norwegian red king crab management was therefore to stop the spread of the crab beyond a limited area (the quota regulated area) in eastern Finnmark, east of $26^{\circ} \mathrm{E}$ (Figure 1), where the crab should be commercially harvested with a long term revenue goal. To limit further spread, a non legislated free fishery was introduced in areas outside the quota regulated area, including a ban on releasing viable crabs back to sea. The main management tools within the quota regulated area today are a minimum legal size (130 $\mathrm{mm}$ carapace length) for catch on males and females, trap limitation and vessel quotas.

The applied management of the red king crab in Norwegian waters seems to be successful regarding limiting the spread of the crab, and keeping the stock low in areas outside the quota regulated area. Keeping an area of long term exploitation, maintains also an economical way of getting rid of all red king crabs caught in Norwegian waters. However, the high densities of crabs inside the quota regulated area have obvious consequences for the benthic fauna since the crab feeding activities both reduce the biomass as well as the species composition of the benthic communities. The long term consequences of these changes are unknown and we fear that maintaining this pressure on the benthic ecosystems may result in a permanent change.

\subsection{The snow crab (Chionoecetes opilio) in the Barents Sea: Summary}

This crab is not deliberately introduced and appeared in the Barents Sea for the first time in 1996. Since then, it has spread to most of the northern areas of the Russian zone and into international waters, the Norwegian zone and Svalbard waters. Little is yet known of the biology of this crab in the Barents Sea, but preliminary studies indicate strong similarities with what is found in native areas. It is expected that the snow crab will occupy most parts of the northern Barents Sea including all Svalbard waters. We also anticipate that this crab may cause serious effects on the benthic fauna within its distribution area. Fishery for the snow crab in the Barents Sea started in 2013, and management plans for this species is expected to be launched during 2014, both for the Russian and the Norwegian zone. 


\subsubsection{Appearance and origin}

In 1996 five snow crabs were caught in the slope areas on the Goose Bank in the Barents Sea by Russian scientist. This was the first recording ever of this species in the North-eastern Atlantic. The natural distribution of the crab is in the Bering Sea, coastal eastern Canada and along the western coast of Greenland. Several hypotheses on the origin of this introduction are proposed. The crab is likely either from the eastern areas or from western Atlantic. In addition, it is also possible that the crab might have moved by itself from the Chukchi Sea in eastern Russia, since examples of the crab have been found both in the East Siberian Sea as well in the Laptev Sea. Genetic analyses are under way which hopefully will reveal the answer to this question.

\subsubsection{Biology and life history}

The knowledge on the biology and life history of the snow crab reveals area specific differences. There seem to exist, however, some common features given below.

Unlike the red king crab the snow crab has a terminal molt as the crab become mature. Female snow crab may be between 30-95 mm carapace width at the terminal most, whilst the sizes of males may vary between 40 and $150 \mathrm{~mm}$ in Atlantic Canada. The crab lives a maximum of five years after the terminal molt (Conan and Comeau 1986, Hartnoll et al. 1993).

Female crabs hatch the old eggs just prior to spawning in the spring. New egg clutches may count between 20 and 150 thousand eggs which are carried under the female abdomen for almost a year (Moriyasu 2011). There are some indications that crabs facing harsh (temperature) conditions may spawn every second year, but annual reproduction period is the common situation (Moriyasu and Lanteigne 1998).

The snow crab larvae drift in the upper sea water column for up to two months and in contrast to the red king crab they do not necessarily settle in shallow areas, but may well be found in deeper ( $>200 \mathrm{~m}$ ) parts of the sea. Juveniles seem however to be more restricted to low temperatures than adult crabs $\left(-1-3^{\circ} \mathrm{C}\right)$, which probably will be a bottleneck for where the snow crab will spread in the Barents Sea (Dionne et al. 2003).

Several numbers of prey groups are found in the diet of the snow crab in the Barents Sea based on stomach analysis (Sundet unpubl.), but species groups such as Polychaeta, mussels and Echinoderms are dominating in the stomachs. This means that we may expect that the snow crab can have effects on major parts of the benthic species communities. 
The growth rate of the snow crab may vary, but it is believed that the crab is about 5-6 years old at the terminal molt, and that maximum longevity is about 15 years.

\subsubsection{Distribution in the Barents Sea}

Since the first recordings of the snow crab in the Barents Sea, the crab has rapidly spread to most parts of the northern Russian Economic Zone and northwestwards into international waters, then Norwegian Economic Zone and the Svalbard Protection Zone (figure 3). There are also findings of single crab specimens along the coast of Finnmark and as far northwest as Olgastredet between King Carls Land and Edge Island. Due to its known temperature preferences it could be expected that the snow crab will continue to spread further north and west in the Barents Sea; most likely will the crab be found around the whole Svalbard and Franz Josef archipelago in the future.

Figure 3: Distribution and density of snow crab in the Barents Sea based on bycatches in bottom trawl during the IMR/PINRO ecosystem survey 2004-2012

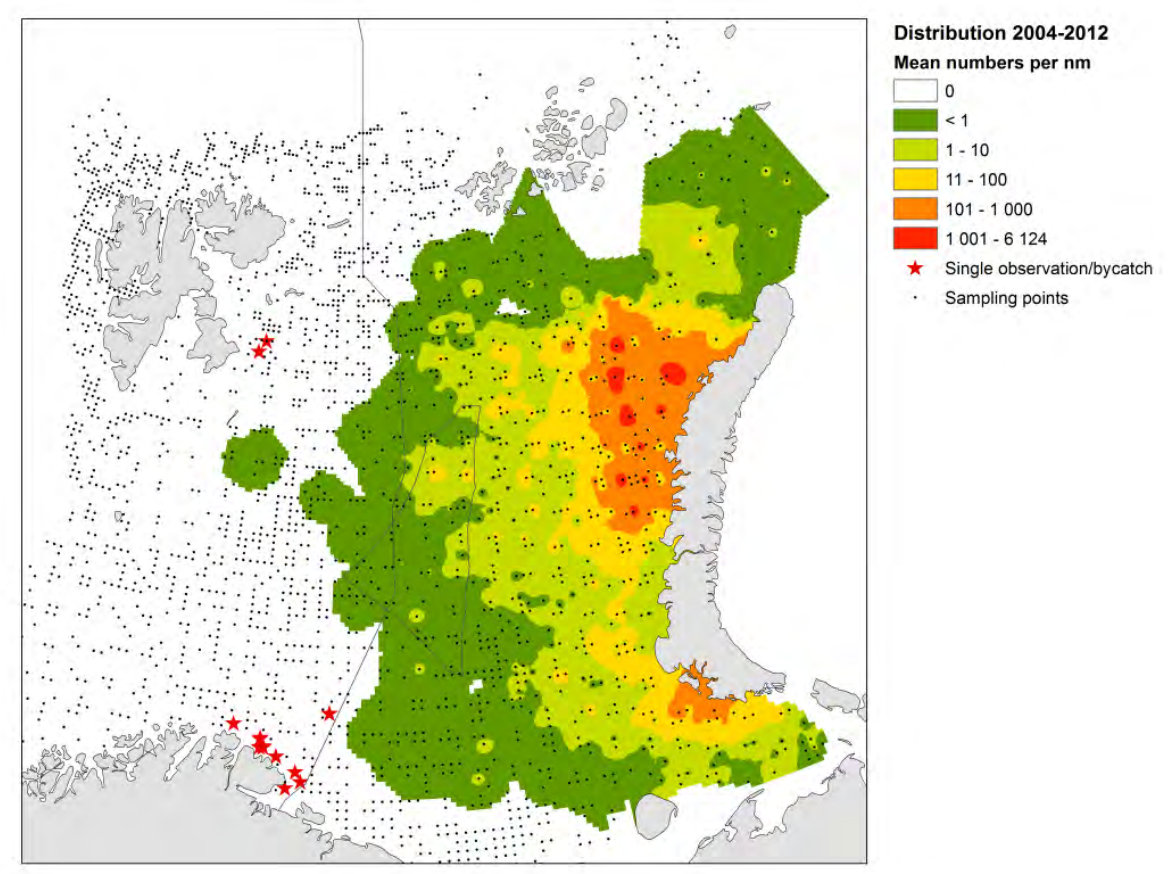

Red asterisks indicate catch sites of single snow crabs 


\subsubsection{Management}

So far there is no management regime for the snow crab in the Barents Sea implemented, neither in the Norwegian nor in the Russian zone, but both countries authorities have announced that they aim to implement management systems for the snow crab during 2014.

\subsection{References}

Anonymous (2007). Forvaltning av kongekrabbe [Management of the red king crab]. Parliament whitepaper no 40/2006-2007, Ministry of Fisheries and Coastal affairs. $144 \mathrm{pp}$.

Conan, G.Y. and Comeau, M. (1986). Functional maturity and terminal molt of snow crab, Chionoecetes opilio. Canadian Journal of Fisheries and Aquaculture. Vol. 49: 2460-2468.

Dionne, M., Sainte-Marie, B., Bourget, E. and Gilbert, D. (2003). Distribution and habitat selection of early benthic stages of snow crab Chionoecetes opilio. Marine Ecology Progress Series, 259: 117-128.

Donaldson, W.E., Byersdorfer, S.C. (2005). Biological field techniques for lithodid crabs. Alaska Sea Grant College Program, University of Alaska Fairbanks, AK-SG-05-03.

Falk-Petersen, J., Renauld, P. and N. Anisimova. 2011. Establishement and ecosystem effects of the alien invasive red king crab (Paralithodes camtschaticus) in the Barents Sea - a review. ICES Journal of Marine Science 68(3): 479-488. DOI: 10.1093/icesjms/fsq192

Feder, H. M., and Jewett, S. C. 1981. Feeding interaction in the eastern Bering Sea with emphasis on the benthos. In: The Eastern Bering Sea Shelf: Oceanography and Resources 2: 1229-1261. D.W. Hood and J.A. Calder (eds.). Office of Marine Pollution Assessment, NOAA, University of Washington Press, Seattle.

Hartnoll, R.G., Bryant, A.D. and Gould, P. 1993. Size distribution in spider crab populations: spatial and temporal variation. Journal of Crustacean Biology. Vol. 13: 647-655.

Haugan, T-A. 2004. Bunnsamfunn og næringsvalg hos kongekrabbe, Paralithodes camtschaticus (Tilesius, 1815), på noen lokaliteter i Finnmark [Benthic communities and prey preferences in the red king crab, in selected localities in Finnmark county]. Master thesis, University of Tromsø, $2004.86 \mathrm{pp}$.

Hjelset, A.M. 2014. Fishery-induced changes in Norwegian red king crab (Paralithodes camtschaticus) reproductive potential. ICES Journal of Marine Science, vol. 71(2):365-373.

Hjelset, A. M., Sundet, J. H. and E. M. Nilssen. 2009. Size at sexual maturity in the female red king crab (Paralithodes camtschaticus) in the Barents Sea, Norway. Journal of Northwest Atlantic Fishery Science 41: 172-182.

Hjelset, A. M., Nilssen, E. M. and Sundet, J. H. 2012. Reduced size composition and fecundity related to fishery and invasion history in the introduced red king crab (Paralithodes camtschaticus) in Norwegian waters. Fisheries Research 121: 73-80 DOI: 10.1016/j.fishres.2012.01.010.

Jørgensen, L. L. 2005. Impact scenario for an introduced decapods on Arctic benthic communities. Biological Invasions 7: 949-957.

Jørgensen, L. L., and Primicero, R. 2007. Impact scenario for the Jørgensen, L. L., and Primicero, R. 2007. Impact scenario for the invasive red king crab Paralithodes 
camtschaticus (Tilesius, 1815) (Reptantia, Lithodidae) on Norwegian, native, epibenthic prey. Hydrobiologia 590: 47-54.

Kuzmin, S., Olsen, S. and Gerasimova, O. 1996. Barents Sea king crab (Paralithodes camtschaticus): Transplantation Experiments Were Successful. High lattitude crabs: Biology, Management and Economics. Proceedings of the International Symposiym on Biology, Management and Economics of Crabs from High Latitude Habitats. Anchorage, Alaska, USA. October 11-13, 1995. pp. 649-664.

McCaughran, D. A., and Powell, G. C. 1977. Growth model for Alaska king crab (Paralithodes camtschatica). Journal of Fisheries Research Board of Canada 34: 989-995.

Moriyasu, M. 2011. Review of the current status of the snow crab Chionoecetes opilio (0. Fabricius, 1788) fisheries and biological knowledge in eastern Canada. New frontiers in crustacean biology: Crustaceana Monographs 15: 95-107. Koninklijke Brill NV, Leiden.

Moriyasu, M. and Lanteigne, C. 1998. Embryo development and reproductive cycle in the snow crab, Chionoecetes opilio (Crustacea: Majidae), in the southern Gulf of St. Lawrence, Canada. Canadian Journal of Zoology, 76 (11): 2040-2048.

Nilssen, E.M. 2003. Kongekrabbe i Barentshavet - biologi og utbredelse. [Red king crab in the Barents Sea - biology and distribution]. Ottar no 4/2003. p.7-12. (in Norwegian).

Nilssen, E.M., Sundet, J.H., 2006. The introduced species red king crab (Paralithodes camtschaticus) in the Barents Sea: II. Growth increments and moulting probability. Fish. Res. 82, 319-326.

Orlov, Y.I., Ivanov, B.G., 1978. On the introduction of Kamchatka King Crab Paralithodes camtschatica (Decapoda: Anomura: Lithodidae) into Barents Sea. Mar. Biol. 48, 373-375.

Otto, R.S., 1986. Management and assessment of Eastern Bering Sea king crab stocks. Can. Spec. Publ. Fish Aquat. Sci. 92, 83-106.

Oug, E., Cochrane, S. K. J., Sundet, J. H., Norling, K. and Nilsson, H.C. 2011. Effects of the invasive red king crab (Paralithodes camtschaticus) on soft-bottom fauna in Varangerfjorden, northern Norway. Marine Biodiversity 41: 467-479. DOI 10.1007/s12526-010-0068-6.

Pedersen, O. P., Nilssen, E. M. Jørgensen, L.L. and Slagstad, D. 2006. Advection of the red king crab larvae on the coast of North Norway - a Lagrangian model study. Fisheries Research 79: 325-336.

Powell, G.C. and Nickerson, R.B. 1965. Aggregations among juvenile king crabs (Paralithodes camtschatica, Tilesius) Kodiak, Alaska. Animal Behaviour, 13: 374-380.

Rafter, E. E., Nilssen, E. M. and Sundet, J. H. 1996. Stomach content, life history, maturation and morphometric parameters of red king crab, Paralithodes camtchaticus, from Varangerfjord area, North Norway. ICES Document CM 1996/K:10. 25 pp.

Sundet, J.H. and Hjelset, A.M. 2002. The Norwegian red king crab (Paralithodes camtschaticus) fishery; Management and bycatch issues. In Crabs in cold water regions: Biology, Management and Economics (ED. A.J. Paul, E.G. Dawe, R. Elner, G.S. Jamieson, G.H. Kruse, R.S. Otto, B. Sainte-Marie, T.C. Shirley and D. Woodby) . University of Alaska Sea Grant, AK-SG-02-01, Fairbanks. 876 pp. 


\section{Invasive Species: Case studies from Iceland}

Gudrun G. Thorarinsdottir, Marine Research Institute, Reykjavík, Iceland; Karl Gunnarsson, Marine Research Institute, Reykjavík, Iceland; Ó. Sindri Gíslason, The University of Iceland's Research Centre in Suðurnes, University of Iceland, Iceland.

\subsection{Introduction}

In the last decades the transport of species to areas outside their natural distribution range has increased enormously, globally. It has been estimated that some 10,000 species are being transported every day throughout the globe and in European coastal waters alone non-native species are discovered on the average every second or third week (Bax et al. 2003, Streftaris et al. 2005). The main pathways of transport are considered to be by humans such as hull fouling of ships, ballast water, transport of aquaculture animals, especially shellfish, and with international aquarium trade (Stachowicz et al. 2002, Padilla and Williams 2004).

By far the biggest group of introduced marine species are benthic organisms, phytobenthos and zoobenthos (Streftaris et al. 2005). Larvae, spores and young stages of benthic species are most likely transported by ballast water while adult stages have a better chance as fouling on ship hulls or associated with mollusc shells that are being transported long-distance. Molluscs and fish have been transfered for aquaculture purposes for centuries and it is still a common practice worldwide. Aquaculture species may transfer diseases (viruses and bacteria) and parasites, and hitch hiking species that can survive in the new environment and potentially cause threat to the native biota (Brenner et al. 2014).

Inter-ocean transport of non-native species has also been facilitated by global warming which has caused reduced Arctic ice cover during summer and aided drift of pelagic species from the North Pacific through the North-western Passage into the North-west Atlantic (Reid et al. 2007, Corbyn 2007). Man-made canals as the Suez Canal have also opened routes for the transport of organisms between oceans (Galil 2009). 
Only a small fraction of the numerous species that are transported over long distances each day survives the transport, and still fewer withstand the environmental conditions at the site where they are released (Crooks and Soulé 1999, Mack et al. 2000).

There are many examples of introduced species that are more successful in their new destination than in the area they originate from. This has in some instances been thought to be caused by the lack of natural enemies in the new habitat (Stæhr et al. 2000).

It may take many years, even decades before the impact of introduced species can be detected (Crooks and Soulé 1999). Of those introduced species that successfully colonize, some become invasive, i.e. affect the recipient habitat and bioregions, economically, and/or ecologically even though the seriousness of the impact can vary greatly. Changed environmental conditions (as e.g. increased sea temperature in the North-Atlantic) may affect the success of a non-indigenous species in the new environment (Occhipinti-Ambrogi 2007, Sorte et al. 2010).

The impacts of introduced species can be either direct e.g. when they alter trophic interactions, interfere with competition (for food and space) and by disease transmission or indirect through habitat modification (Snyder and Evans, 2006, Wallentinus and Nyberg 2007). The consequences are changes in species diversity of the native biota (Eastwood et al. 2007, Williams and Smith 2007, Hollebone and Hay 2008, Weis 2010) and in some instances displacement of native species (McDonald et al. 2001). Hybridisation has also been indicated as a consequence of introduction of new species but has scarcely been studied (Coyer et al. 2007).

The highest number of registered invasions of non-native marine species, is in Europe. These species belong to almost all groups of marine organisms from bacteria to fish (Streftaris et al. 2005), and the majority originates from the Pacific (Molnar et al. 2008).

Although the number of non-native species is relatively well known in Europe little is known of their effect on local biota. Studies indicate that invasive non-native species can cause changes in the recipient biota and are considered to be the greatest threat to biodiversity and ecology of marine communities in European coastal waters (Bax et al. 2003). Because of that, there is an identified need by the scientific community for a risk-based assessment of the transport and introduction of nonnative species. Risk assessments should include all possible effects of the introduction both direct effects and side effects such as diseases, hitch hiking species and genetic contamination (Muehlbauer et al. 2014).

Human induced introductions of non-native species in Icelandic waters have increased in the last decades. Most of these species originate 
from the Pacific and are brought to Iceland from Europe as a secondary introduction (Table 1). Only minor negative effects on the ecosystem have been reported for these species in Iceland. However, it is emphasised that there have been limited ecological studies of their interaction with native species.

\begin{tabular}{|c|c|c|c|c|}
\hline Taxa & First recorded & Pathway & Invasive & References \\
\hline \multicolumn{5}{|l|}{ Phytoplankton } \\
\hline Heterosigma akashiwo & 1987, Southwest & Shipping & No & $\begin{array}{l}\text { Thorarinsdottir and } \\
\text { Thordardottir } 1997\end{array}$ \\
\hline Stephanopyxis turris & 1997 Southwest & Shipping & No & Gunnarsson et al. 2011 \\
\hline Mediopyxis helysia & 2007, West & Shipping & No & Gunnarsson et al. 2011 \\
\hline Neodenticula seminae & 2002, North & Currents & No & Reid et al. 2007 \\
\hline \multicolumn{5}{|l|}{ Macroalgae } \\
\hline Fucus serratus & 1900, Southwest & Shipping & Potentially & Jónsson 1903 \\
\hline Codium fragile & 1974, Southwest & Shipping & No & Jónsson and Gunnarsson 1975 \\
\hline Bonnemaisonia hamifera & 1978, Northwest & Shipping & No & $\begin{array}{l}\text { Gunnarsson and } \\
\text { Egilsdóttir } 2010\end{array}$ \\
\hline \multicolumn{5}{|l|}{ Crustacea } \\
\hline Cancer irroratus & 2006, Southwest & Shipping & Potentially & Gislason et al. 2014 \\
\hline Crangon crangon & 2003, Southwest & $\begin{array}{l}\text { Shipping/ } \\
\text { currents }\end{array}$ & Potentially & Gunnarsson et al. 2007 \\
\hline \multicolumn{5}{|l|}{ Mollusc } \\
\hline Mya arenaria & 1958, Southeast & Shipping & No & Óskarsson 1982 \\
\hline Cerastoderma edule & 1948, Southwest & Shipping & No & Óskarsson 1982 \\
\hline \multicolumn{5}{|l|}{ Tunicata } \\
\hline Ciona intestinalis & 2007, Southwest & Shipping & No & Svavarsson and Dungal 2008 \\
\hline \multicolumn{5}{|l|}{ Fish } \\
\hline Platichtys flesus & 1999, Southwest & $\begin{array}{l}\text { Shipping/ } \\
\text { currents }\end{array}$ & Potentially & Jónsson et al. 2001 \\
\hline Oncorhynchus mykiss & 1983, Southwest & Acuaculture & No & Jónsson 1983 \\
\hline
\end{tabular}

In this article we describe the present status of non-native marine species in Icelandic waters. We attempt to identify their distribution in Iceland and the vectors for spread, and how the introduced species interact with the local biota. 


\subsection{Phytoplankton}

\subsubsection{Heterosigma akashiwo (Y. Hada) Y. Hada ex Y. Hara \& M. Chihara}

A blooming of the planktonic algae Heterosigma akashiwo (Figure 1) in Hvalfjörður was observed in May 1987 causing massive mortality in pen reared salmon at a local fish farm (Thorarinsdottir and Thordardottir 1997). The species has only been found in Iceland on this one occasion. This could possibly be explained by a single introduction event during optimal environmental conditions, as the species did not survive the conditions for the rest of the year and died out.

\section{Figure 1: Heterosigma akashiwo}

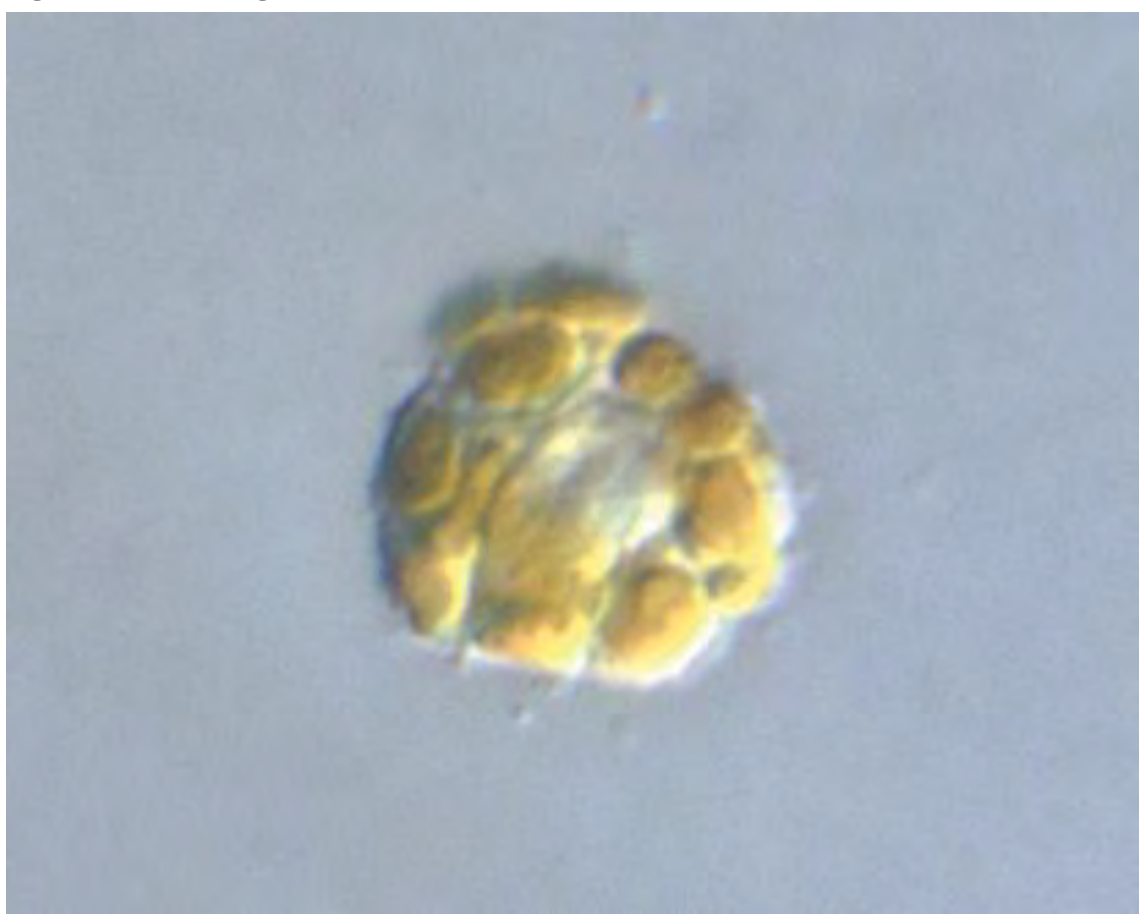

Photo: Wenche Eikrem and Jahn Throndsen.

H. akashiwo was first formally described form Japan in 1967 (see Hara and Chihara 1987). In Europe it was first reported from a dens bloom in Oslofjord in 1964 (Braarud 1969). Since then it has been reported in many places in the North Atlantic where it has caused several incidents of mortality in farmed fish and shellfish. Due to the close genetic relationship that exists between Pacific and Atlantic populations H. akashiwo 
has been thought to have been introduced recently into the Atlantic, possibly by humans (Connell 2000). But given the global distribution of this species this has been challenged (Smayda 2006).

\subsubsection{Stephanopyxis turris (Greville et Arnott) Ralfs}

The diatom Stephanopyxis turris (Figure 2) was first recorded in 1997 when it was found in Hvalfjörður (Eydal 2003, Gunnarsson et al. 2011). It has since been found in Faxaflói and Breiðifjörður. S. turris is a common species at the Atlantic coast of Europe and the east coast of North America. The species had not been found in numerous surveys in the area until it suddenly appeared and was found in high concentrations in Hvalfjörður. It is therefore suspected that it was introduced a shortly before it was first recorded.

Figure 2: Stephanopyxis turris

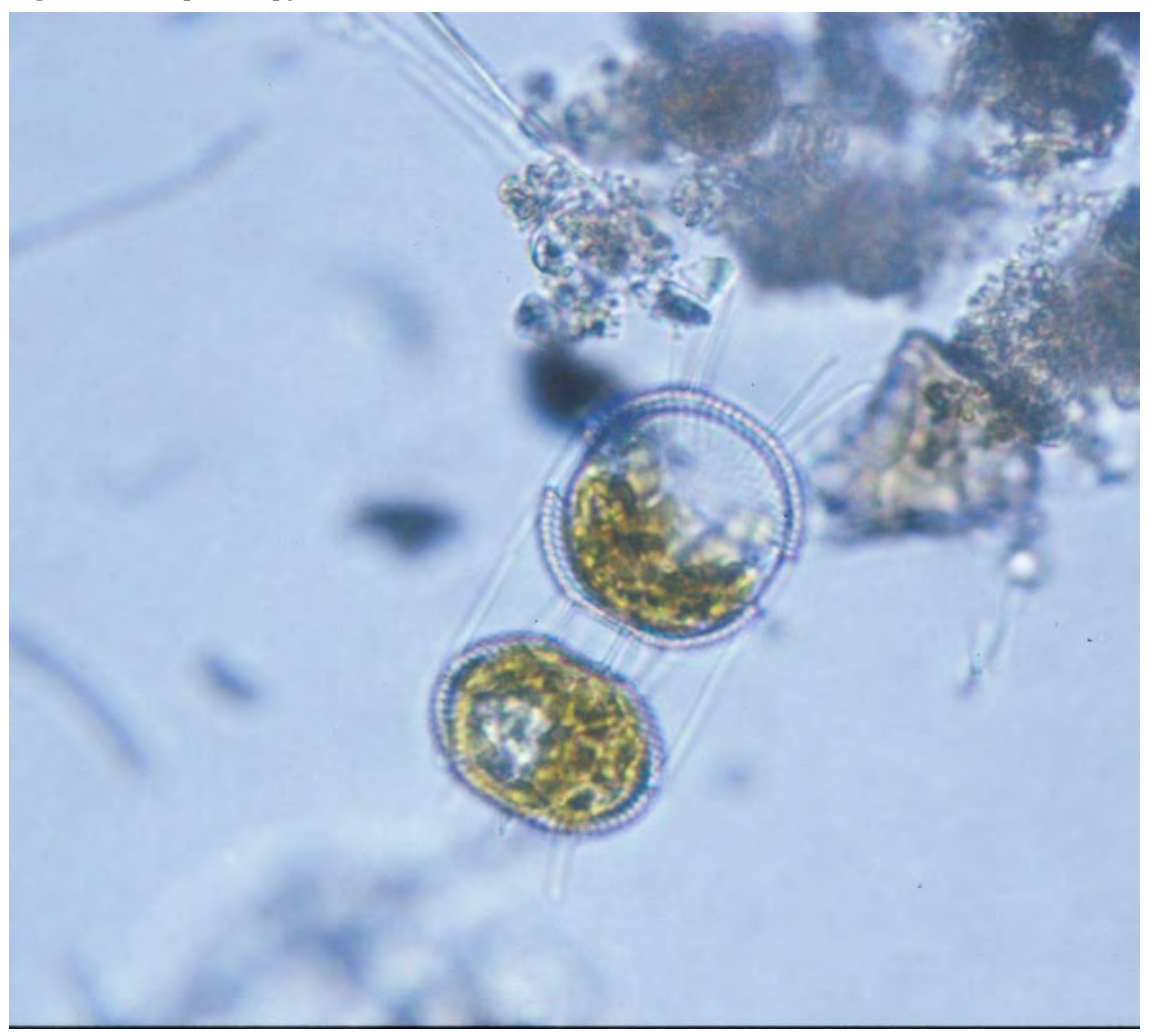

Photo: Karl Gunnarsson. 


\subsubsection{Mediopyxis helysia Kühn, Hargraves et Hallinger}

The first formal description of the diatom species Mediopyxis helysia (Figure 3) was published in 2006 (Kühn et al. 2006). It was first found in samples collected on the west coast of North America in 1996. Subsequently it was found close to Helgoland in the North-Sea coast in 2002, and at the Scottish coast in 2005 (McCollin 2008). It is not known from where it originates but detailed examinations of samples from the west coast of N-America and Helgoland in the years prior to its discovery did not reveal any individuals of this relatively large and conspicuous species (Martin and LeGresley 2008, Kraberg et al. 2012).

In 2007 through 2010 the species was found at numerous occasions in Breiðafjörður western Iceland (Gunnarsson et al. 2011) and in Hvalfjörður in 2010. Recently it was found in samples collected in 2008 in Tálknafjörður, north-western Iceland (H. Gudfinnson MRI, personal communication). Re-examining of samples from Breiðafjöður and Hvalfjörður taken before its discovery in 2007 did not yield any additional records of the species.

\section{Figure 3: Mediopyxis helysia}

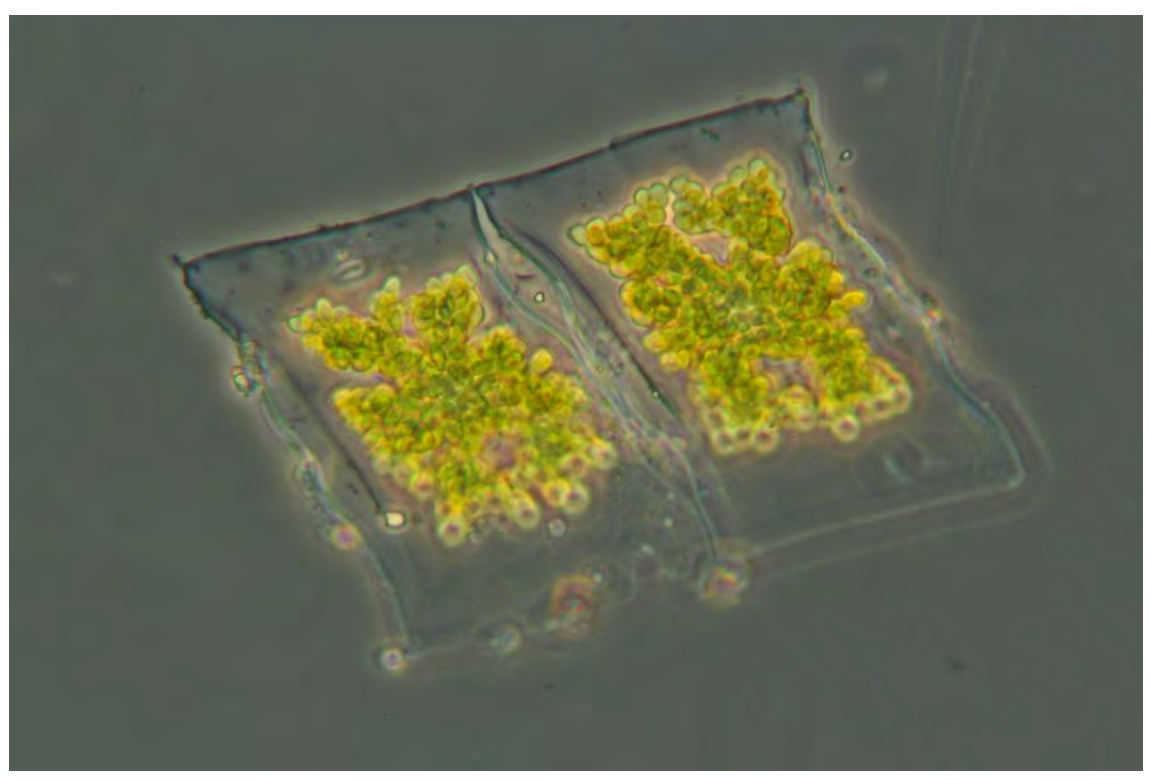

Photo: Karl Gunnarsson.

In the Wadden Sea the species has become established and has repeatedly formed extended blooms (Meier and Hillebrand 2012). Its dominance in the plankton community has affected the diversity of the phytoplankton and consequently it has been considered to be an invasive species. 


\subsubsection{Neodenticula seminae (Simonsen et Kanaya) Akiba et Yanagisawa}

Neodenticula seminae (Figure 4) was discovered in Icelandic waters in samples collected by continuous plankton recorders (CPR) in 2003 and in samples taken in the North Icelandic waters in 2002 (Reid et al. 2007). The species was first detected in the North Atlantic in 1999 in the CPR series south of Greenland. Recently it was found to be abundant in the Nordic Seas up to Svalbard (Miettinen et al. 2013). It has probably drifted with currents from the Pacific along the Northwest Passage as a result of longer ice-free periods in summer in the Canadian Arctic (Corbyn 2007).

\section{Figure 4: Neodenticula seminae}

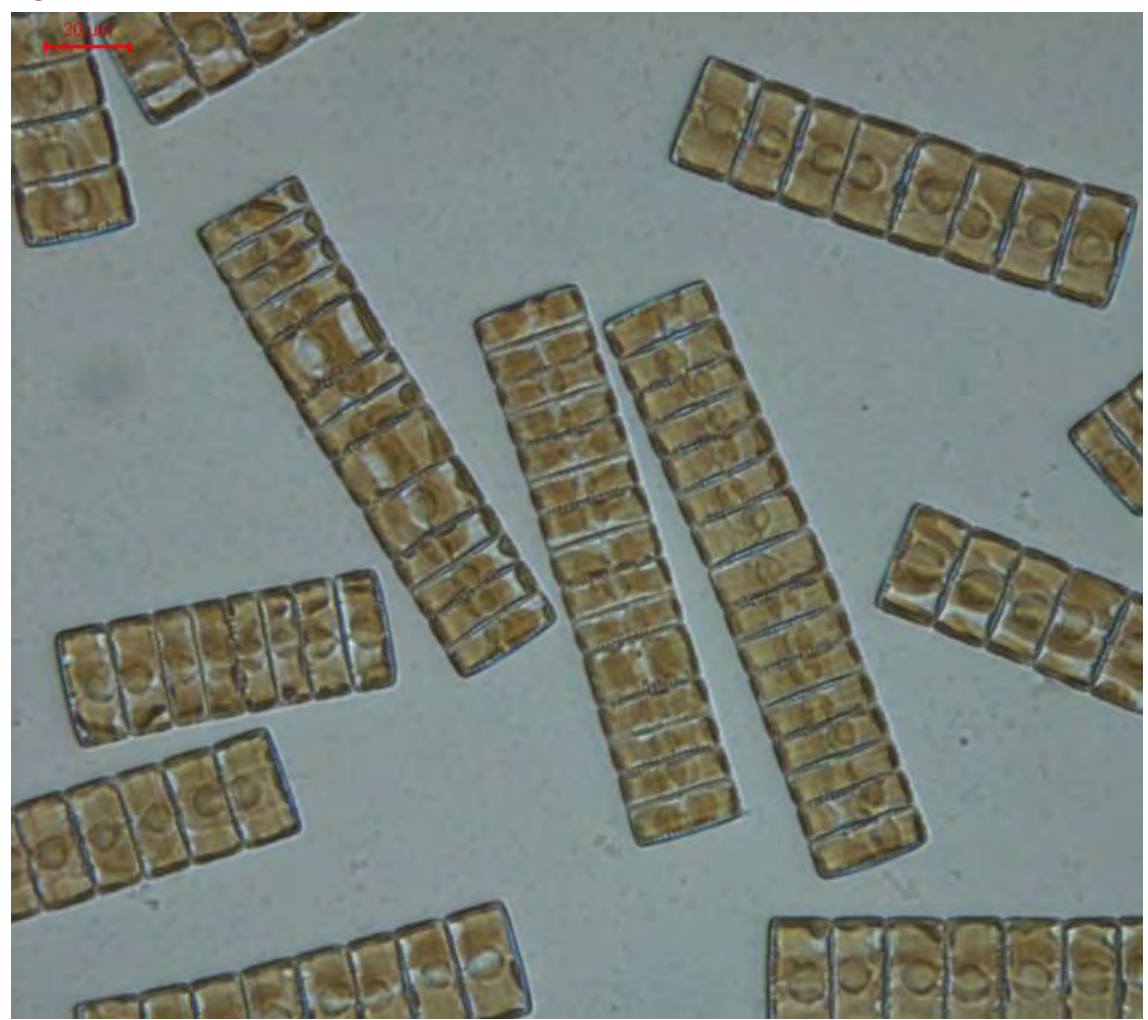

Photo: Akira Kuwata.

$N$. seminae has until now only been found in two samples from Icelandic waters. One of the samples was taken off the south coast and the other one on the northern shelf. It was not introduced by humans but its introduction was facilitated by global warming and resulting ice melting in the Arctic. 


\subsection{Macroalgae}

\subsubsection{Fucus serratus Linneaus}

The brown seaweed F. serratus (Figure 5), native to the Atlantic coast of Europe, was probably introduced to Iceland by man. It was first recorded at the end of the $19^{\text {th }}$ century in two isolated populations in south-western Iceland (Jónsson 1903). In recent years the population has extended its distribution over most of the western and northern shore of Reykjanes peninsula, south-western Iceland. Additionally, small isolated population was found in Hvalfjörður in 1998 which now covers most of the shores in the inner and middle part of the fjord. Molecular genetic analyses indicate that $F$. serratus was introduced to Iceland a few centuries ago and has since spread from Iceland to the Faroe Islands (Coyer et al. 2006).

\section{Figure 5: Fucus serratus}

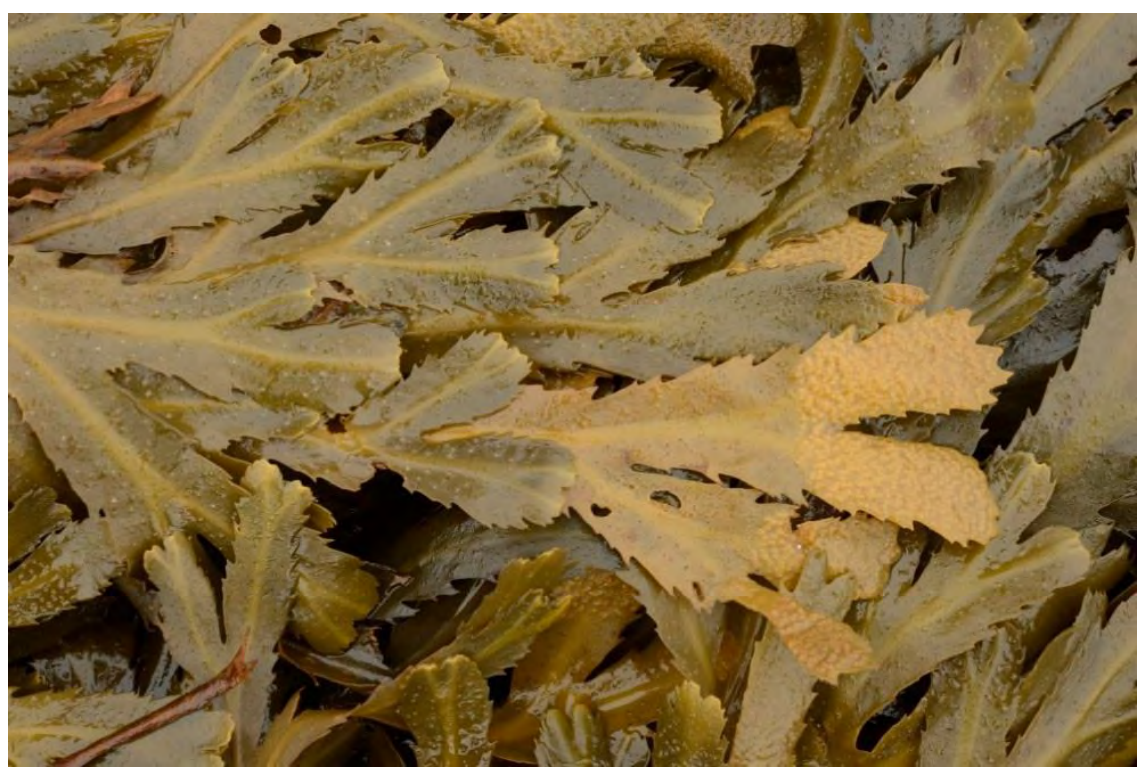

Photo: Karl Gunnarsson.

Hybridisation is commonly found between F. serratus and F. distichus especially in areas where the species have recently started growing together i.e. when one is introduced into the habitat of the other. In Iceland hybrids are commonly found between the two species (Coyer et al. 2006). These hybrids seem to be most common at the edges of the spreading area of $F$. serratus where the two species are in direct contact. 
In old established populations, F. serratus is considered a week competitor with other canopy forming species (Hawkins and Harkin 1985). Studies in Iceland have however shown that the growth of $F$. serratus affects or eliminates the growth of other canopy-forming species normally found growing at the same level in the lower part of the shore (Gunnarsson and Galan 1990, Ingólfsson 2008). When established, F. serratus becomes dominant by forming a canopy cover in the lower part of the shore, reducing or eliminating the cover of other canopy forming algae. It can therefore be classified as an invasive species.

\subsubsection{Bonnemaisonia hamifera Hariot}

The Japanese red seaweed Bonnemaisonia hamifera (Figure 6) was first recorded in the North Atlantic at the end of the 19th century. It spread from Europe to the west coast of North America where it was recorded in 1927. First record of it in Iceland was sometimes between 1964 and 1975 (Munda 1978). The species normally has a life cycle with morphologically dissimilar phases. Its sporophytic phase is made of thin filaments, growing closely attached to the substrate or forming small tufts. The gametophytic phase is a larger, upright fleshy plant. B. hamifera i.e. the sporophytic phase was first reported growing on Fucus distichus in the intertidal zone in Dýrafjörður. The species was recorded again in 2004, when it was found subtidally in Hvalfjörður, again it was only the sporophytic phase that was found and it was growing attached to the calcareous algae Lithothamnion (Gunnarsson and Egilsdóttir 2010). It formed small, pink tufts on the host. The gametophytic phase has not been reported in Iceland. 


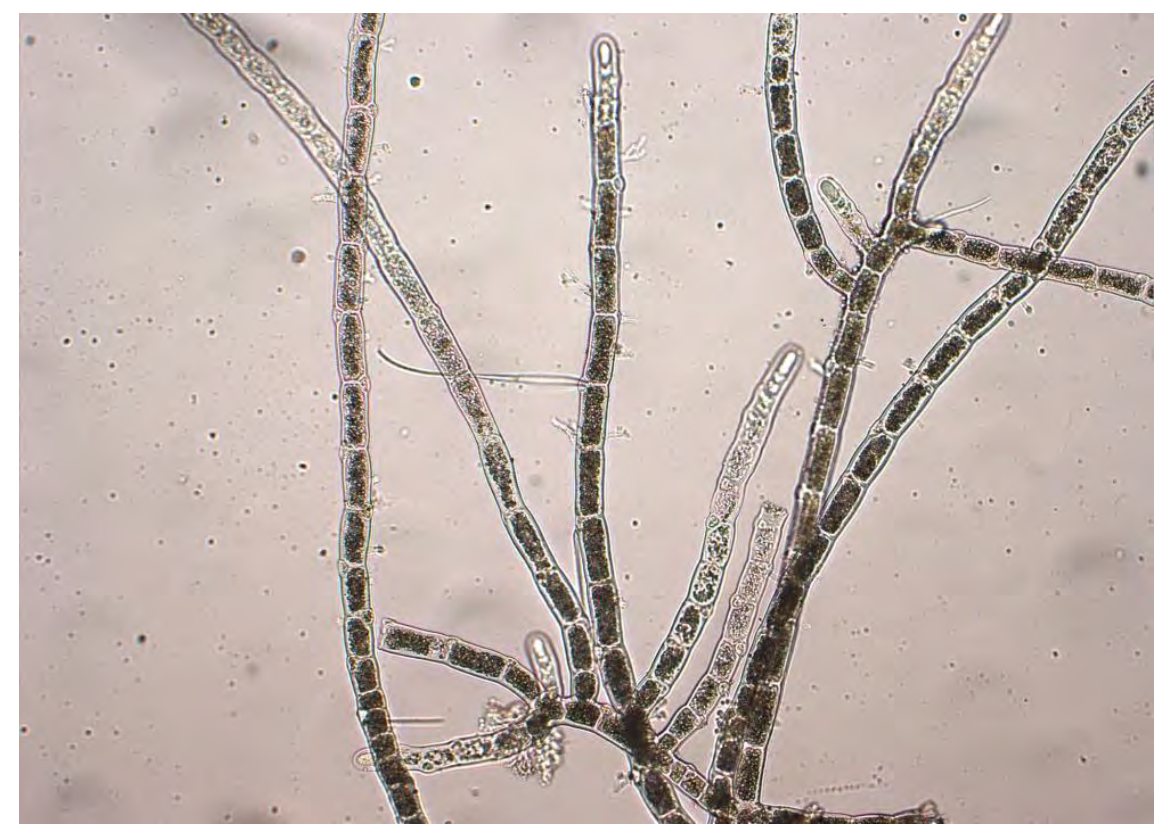

Photo: Svanhildur Egilsdóttir.

In Europe and the west coast of North America reproductive structures have been observed both on gametophytic and sporophytic plants (Floc'h 1969, Chen et al. 1969). The species is however thought to spread primarily by fragmentation. No reproductive structures have been found on the species in Iceland. Sporophytes have a wider distribution in the North Atlantic than the gametophytes and are the only life cycle stages found close to its northern distribution limit. Here it seems to spread exclusively by fragmentation. Experiments have though shown that the sporophytes are able to form spores when the sea temperature is above $10{ }^{\circ} \mathrm{C}$ during short day conditions ( $\left.\mathrm{d}<12 \mathrm{hrs}\right)$. It occasionally happens in Iceland that the temperature is above $10^{\circ} \mathrm{C}$ after the autumn equinox but does probably not last long enough for the spores to mature and germinate to form viable gametophytes.

Bonnemaisonia hamifera is has been found to be invasive in other areas, but in Iceland it is rare inconspicuous and cannot be termed invasive.

\subsubsection{Codium fragile (Suringar) Hariot}

The green seaweed Codium fragile (Figure 7) was first recorded in Iceland in 1974 when it was found in Hvalfjörður, southwestern Iceland (Jónsson and Gunnarsson 1975). It has now also been recorded on the 
western and northern coast of the Reykjanes peninsula (Gunnarsson and Egilsdóttir 2010). The plants grow up in spring from filamentous masses left at the holdfast from previous summer. The macroscopic plants disappear again in late autumn. No reproductive structures have been found on the Icelandic plants.

\subsection{Figure 7: Codium fragile}

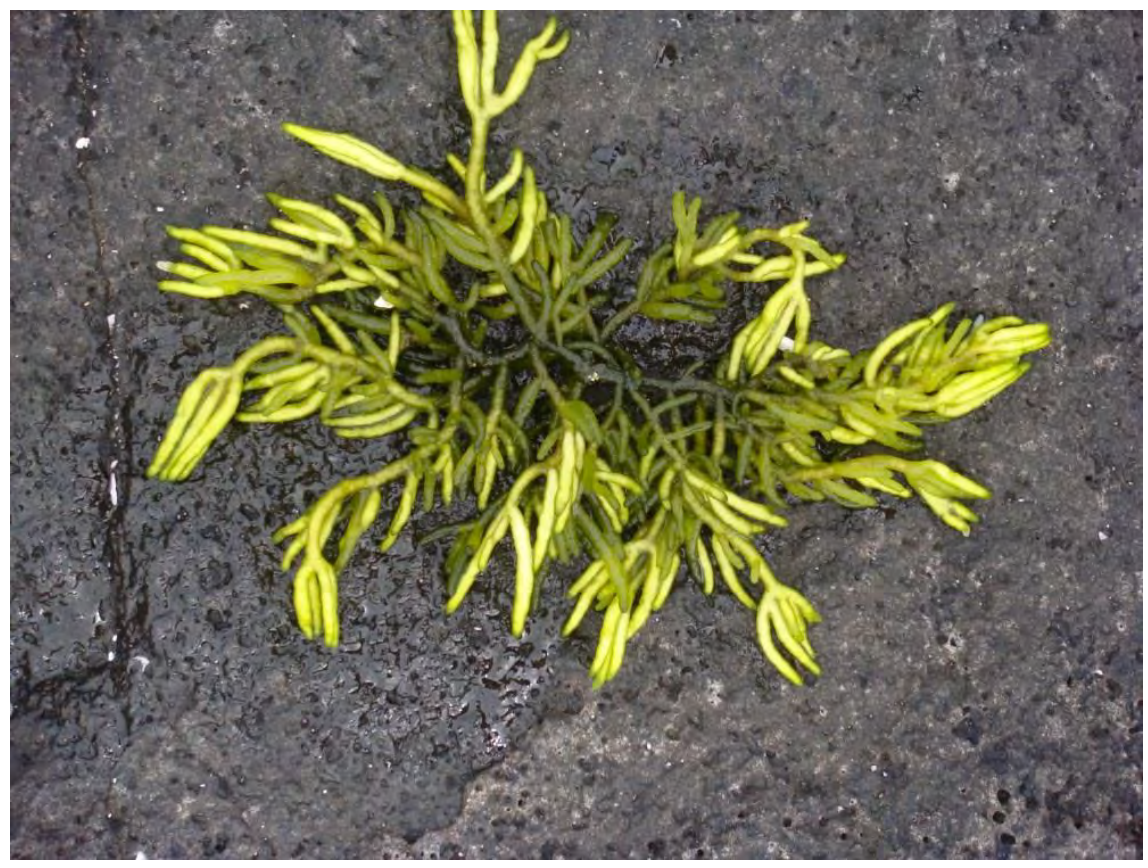

Photo: Karl Gunnarsson.

Codium fragile is a very morphologically variable species and numerous subspecies have been described that can be difficult to distinguish. In the North Atlantic three subspecies have been described; subspecies tomentosoides, atlanticum and scandinavicum. It was thought that the different subspecies were introduced from the Pacific in three separate events (Silva 1955, 1957). Later studies have indicated that there are actually only two subspecies in the North Atlantic; subspecies fragile and subspecies atlanticum. The subspecies fragile is now the only one considered to have been introduced from the Pacific to the North Atlantic, subspecies atlanticum is considered to be native (Brodie et al. 2007, Provan et al. 2008). In Iceland $C$. fragile is found in rock pools in the upper litto- 
ral and just below low watermark at spring tide. The biggest specimens are $15 \mathrm{~cm}$.

In Europe and the east coast of North America the species has become very common and dominates the vegetation in places (Scheibling and Gagnon 2006). Sometimes causing nuisance e.g. by dislodging commercial shellfish and clogging dragnets (Fralick \& Matthieson 1973, Carlton and Scanlon, 1985) and therefore defined as an invasive species. In Iceland, however, Codium fragile is nowhere common although it has been present for at least 40 years and does not show any invasive characteristics here.

Studies have shown that for reproduction to occur in $C$. fragile the sea temperature needs to reach at least $12{ }^{\circ} \mathrm{C}$ (Churchill and Moeller 1972). In Iceland the temperature often exceeds this limit during late summer in the inner parts of fjords in the southwest and west part of the country (Jónsson 1999). Therefore $C$. fragile might occasionally be able to reproduce in Iceland or at least start developing reproductive structures.

\subsection{Crustaceans}

\subsubsection{Cancer irroratus Say, 1817}

The Atlantic rock crab Cancer irroratus was first recorded in Icelandic waters in 2006 (Gíslason et al. 2014). This was as well the first record of the species colonization out of its native range, the Atlantic coast of $\mathrm{N}$ America (Williams 1984). This relatively large decapod crab (Figure 8), with carapace width up to $15 \mathrm{~cm}$, is considered to have been introduced to Iceland as larvae via ballast water (Gíslason et al. 2014). The large scale changes in the North Atlantic in recent years (Anonymous 2004), with noticeable warming in Icelandic waters (Astthorsson et al. 2012) are likely to have aided the colonization. Since colonization $C$. irroratus has spread quickly along the southwest and west coast of Iceland, and has now colonized approximately $20 \%$ of the coastline. In its new habitat competing decapods are scarce, with only two commonly found, the European green crab (Carcinus maenas) and the great spider crab (Hyas araneus). Despite of its recent colonization $C$. irroratus appears to be the dominant brachyuran crab species in south-western Iceland, both regarding adults and planktonic larvae (Gíslason et al. 2014). The density of adult $C$. irroratus was estimated to be around 0.12 crabs per square meter (Gíslason et al. 2013a) which is similar to observations in its native range (Miller 1989). Studies on the genetic population structure 
revealed that the genetic variation in the Icelandic population is high and similar to what it is in its native range (Gíslason et al. 2013b, Gíslason et al. 2013c). Nothing is yet known about the predator-prey interaction and effects of $C$. irroratus on marine ecosystems in Iceland. Considering the size and generalist $\operatorname{diet} C$. irroratus is capable of having significant effects on a variety of native benthic organisms, e.g. through direct predation, competition for habitat or indirect trophic cascades (Gíslason et al. 2014).

Figure 8: Cancer irroratus

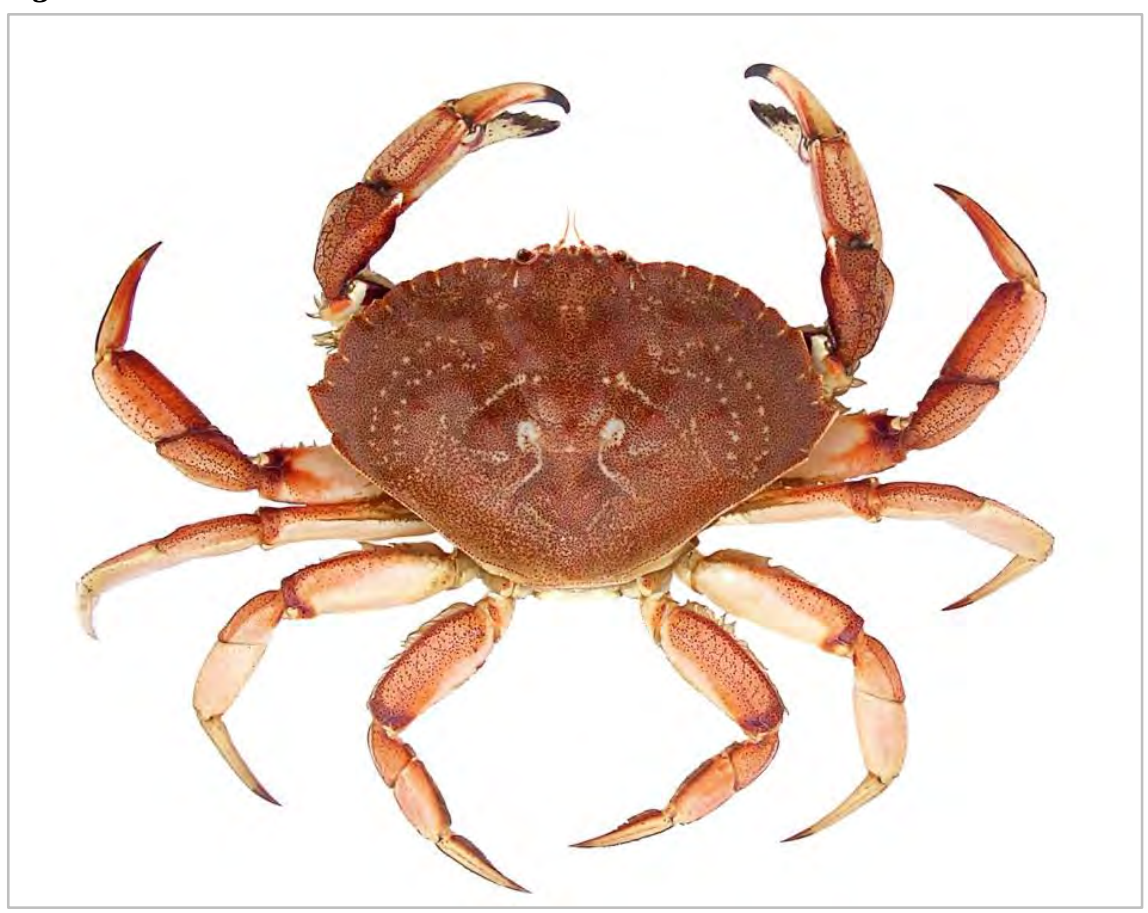

Photo: Ó. Sindri Gíslason.

The size and abundance of adult crabs, their reproductive condition, occurrence of all larval stages in plankton, high genetic diversity, apparent lack of founder effects and rapid spreading of the species along the coastline indicate that the newly established $C$. irroratus population is healthy and is thriving well in Icelandic waters. Thus according to current knowledge, $C$. irroratus has the potential to become invasive in Icelandic waters. 


\subsubsection{Crangon crangon (Linnaeus, 1758)}

The European brown shrimp (Crangon crangon) (Figure 9) was first recorded in Icelandic waters in 2003 (Gunnarsson et al. 2007). In light of its occurrence in Arctic waters, and with records of its incidental observations in Icelandic waters dated back to the late 19th century (Campos and van der Veer 2008, Doflein 1900), it is interesting that successful colonization has not occurred before. The species native distribution extends from the White Sea and northern Norway, the Baltic in the north to the Atlantic coast of Morocco, including the Mediterranean and the Black Sea in the south (Campos and van der Veer 2008, Tiews 1970) where the shrimp inhabits eulittoral and sublittoral soft-bottom habitats of temperate waters, commonly in large numbers (Henderson and Holmes 1987, Hostens 2000). Since colonization C. crangon has spread quickly along the south and west coast of Iceland, and has as well isolated population in the southeast Iceland (Gunnarsson et al. 2007, Kolbenstein 2013). Introduction of $C$. crangon in Icelandic waters is either thought to have occurred naturally via larval drift by currents or by multiple introductions via ballast water, or even both. Known ecological impacts of its colonization in Iceland has not been estimated, the density of $C$. crangon has however been measured as high as 6,700 animals per $100 \mathrm{~m}^{2}$ (Gunnarsson et al. 2007). In general C. crangon is a carnivorous nocturnal predator with diet determined by the composition of the benthic community and the abundance of available prey, both of which are strongly correlated with substrate type (Ansell et al. 1999). As C. crangon has also been implicated as a major predator of young plaice (Pleureonectes platessa L.) on nursery grounds (Oh et al. 2001, van der Veer et al. 1998, Wennhage 2002) its possible impact in Iceland is of special concern as the plaice is a commercially valuable species. 
Figure 9: Crangon crangon

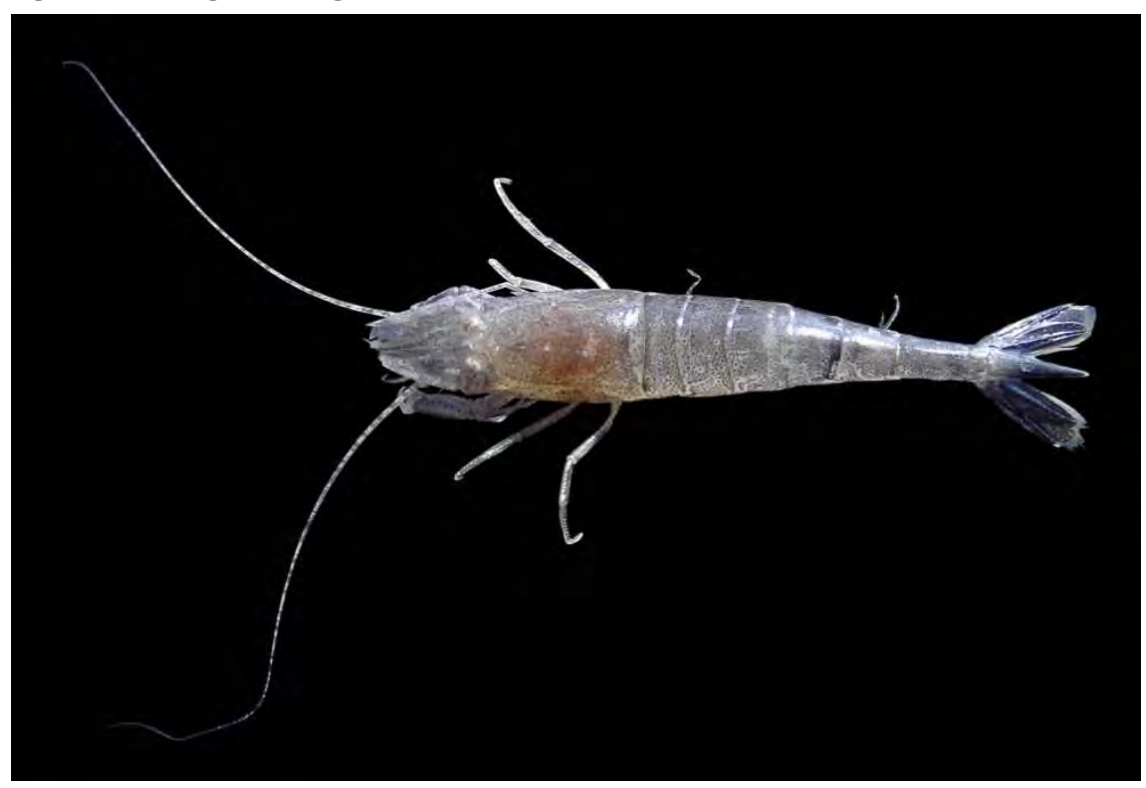

Photo: Hans Hillewaert.

\subsection{Molluscs}

\subsubsection{Mya arenaria Linnaeus, 1758}

Mya arenaria, the Sand gaper, (Figure 10) is found in all European seas and is widely distributed along European coasts (Poppe and Goto 1993, Strasser 1999). This is the oldest introduced species documented in European waters, as shells found in Denmark have been dated back to 1245-1295 (Petersen et al. 1992). This species was first observed off the east coast of Iceland in 1958 (Óskarsson 1982). Since then it has been found at several places almost all around Iceland but always in low abundance (Thorarinsdottir et al. 2007). The transport of M. arenaria to Iceland is most probably from Europe by natural currents and/or ballast water. It is difficult to identify impacts of M. arenaria in Icelandic waters, but in the Baltic (Obolewski and Piesik 2005) and in Danish fjords (Christiansen et al. 2006, Petersen et al. 2008) this species has invaded and caused regime shift in the last decades. 


\section{Figure 10: Mya arenaria}

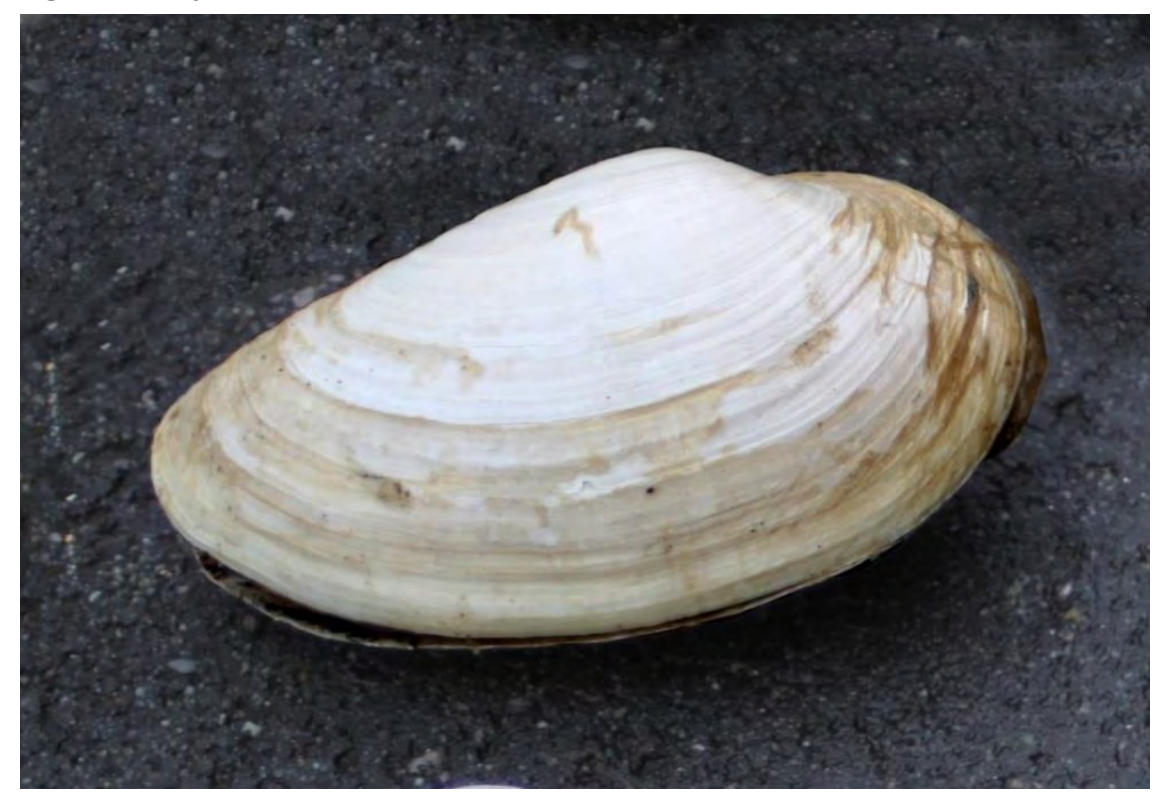

Photo: Gudrun G. Thorarinsdottir.

\subsection{Cerastoderma edule (Linnaeus, 1758)}

The Common cocle, Cerastoderma edule, is widely distributed in the Northeast Atlantic Poppe and Goto 1993) and was first observed in south-western Iceland in 1948 (Óskarsson 1982). The distribution has increased since then but is restricted to the west coast most probably related to sea temperature (Figure 11). The transport to Iceland is most probably from Europe by natural currents and/or ballast water. The impact is hard to detect as it is always found in very low abundance, but the species might compete for resources such as food and space with other bivalve species in the same locality as Arctica islandica and Serripes groenlandicum. 
Figure 11: Cerastoderma edule

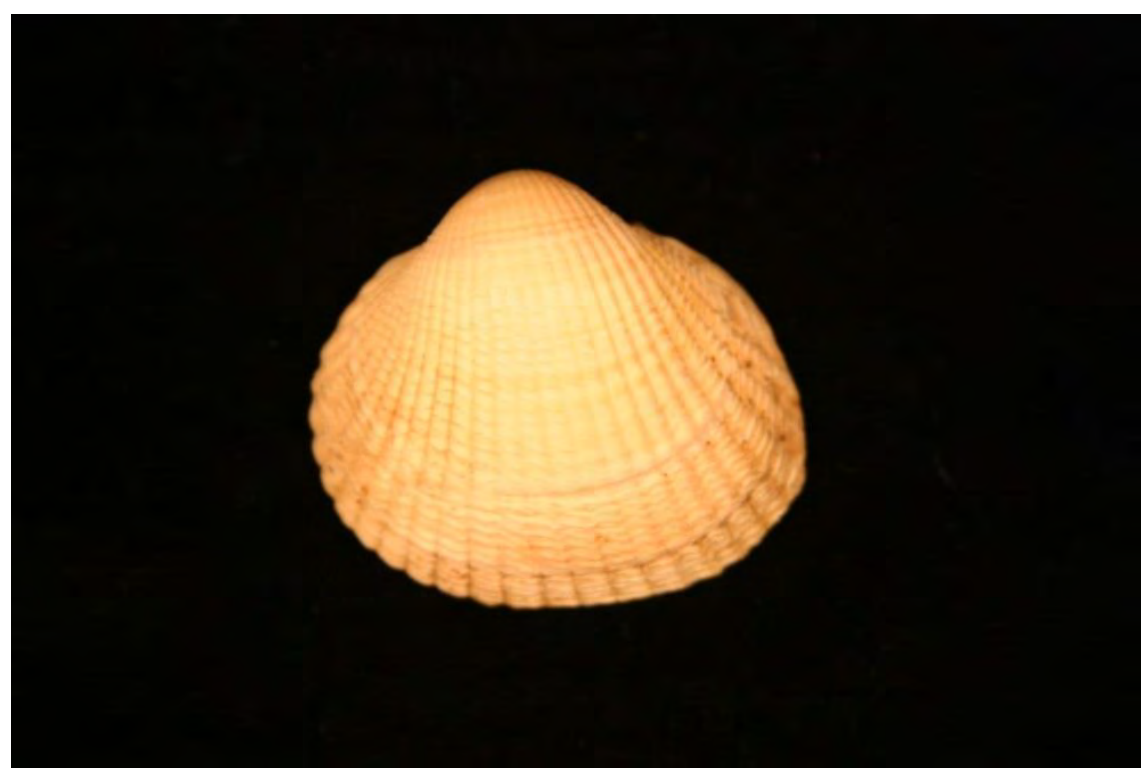

Photo: Gudrun G. Thorarinsdottir.

\subsection{Tunicata}

\subsubsection{Ciona intestinalis (Linnaeus, 1767)}

Tunicates commonly foul ships and docks and are transported around the globe with ships. The Sea vase tunicate, Ciona intestinalis, (Figure 12) is the only tunicate species that has been recorded as non-native in Icelandic waters. This species, is globally distributed except in Antarctica and is native to the North Atlantic, but is introduced to the South Atlantic, Pacific, and Indian Oceans (Dybern 1967). C. intestinalis is listed as an invasive species in Canada (Therriault and Herborg 2008, Carman et al. 2010) and South Africa (Robinson et al. 2005) having negative economic impacts on shellfish aquaculture, reducing growth rates of cultured mussels and fouling ropes and equipment. It is also a formidable competitor, quickly occupying space and potentially displacing native fouling species. 
Figure 12: Ciona intestinalis

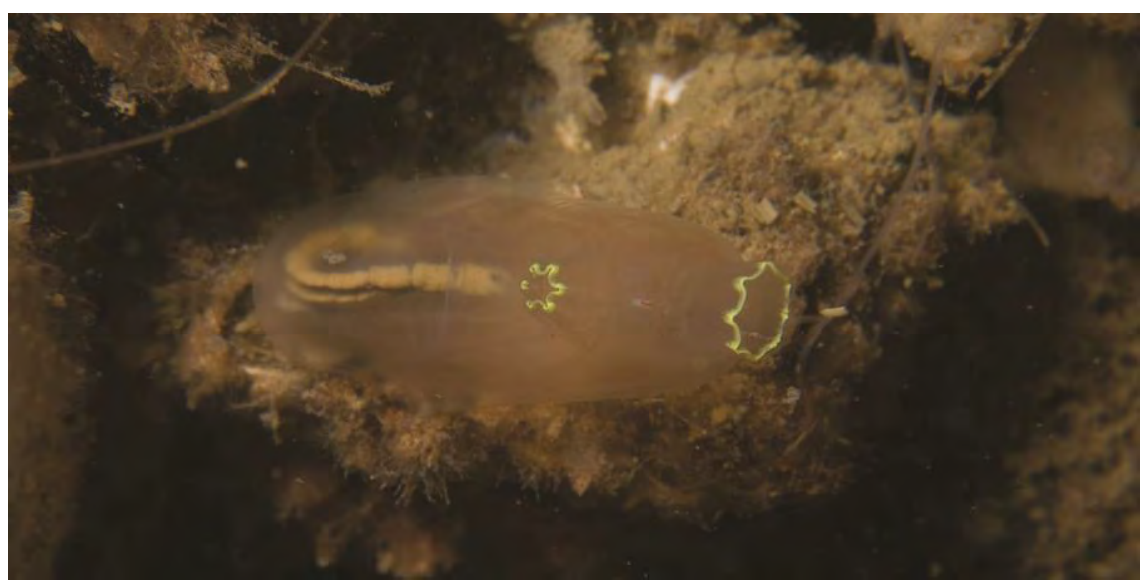

Photo: Pálmi Dungal.

In Iceland C. intestinalis was first recorded in 2007 in a harbour in Straumsvík, south-western Iceland (Svavarsson and Dungal 2008) and again in 2010 from floating docks in three small harbours also in the Southwest (Björnsson 2011). The tunicate has most probably been transported to Iceland as fouling organism on ship hulls. The impact of $C$. intestinalis in Iceland is impossible to detect yet, as it has just lately been recorded at few sites and in low abundance. This species is potentially invasive causing problems in bivalve aquaculture where it has been introduced (Hayes et al. 2005, Lambert and Lambert 2003) so further investigations are needed.

\subsection{Fish}

\subsubsection{Platichthys flesus (Linnaeus, 1758)}

The European flounder, Platichthys flesus, (Figure 13) is widely distributed in the Northeast Atlantic and common in coastal waters in Western Europe as in the Faeroes (Muus et al. 1997, Joensen and Taaning 1970). In autumn 1999 P. flesus was first observed near the mouth of the Ölfusá river, on the south west coast of Iceland (Jónsson et al. 2001, Gudbrandsson and Jónsson 2004). Since then the distribution of the species has increased greatly and it can now be found clockwise around Iceland from the east to the north, in brackish water (Jónsson et al. 2001). The introduction pathway for $P$. flesus is unknown, it is considered to be either by natural dispersal with currents from the Faroese or human me- 
diated with ballast water. Records of such human mediated transport are known from the United States for P. flesus, though not resulting in successful colonization (Welcomme 1988). Studies on the flounder in Iceland have shown predation on salmon larvae as well as competition for food with salmon, eel and stickleback (Jóhannsson and Jónsson 2007). The species is considered as potentially invasive.

\section{Figure 13: Platichthys flesus}

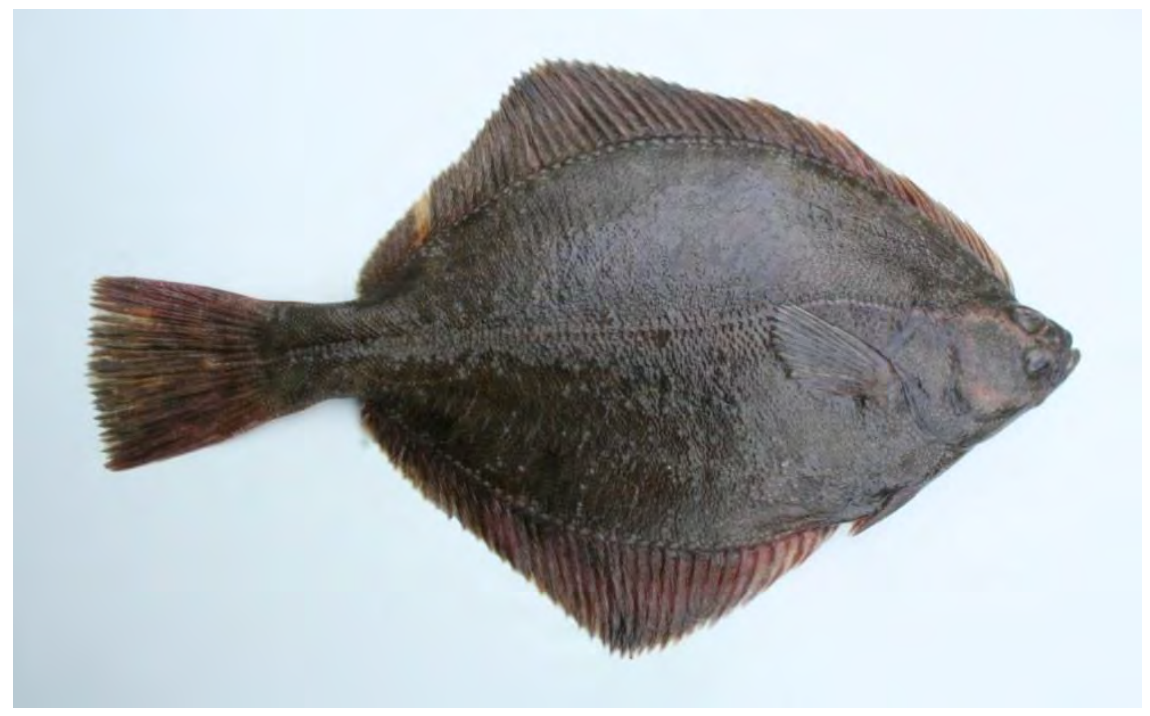

Photo: Jónpáll Pálsson.

\subsubsection{Oncorhynchus mykiss (Walbaum, 1792)}

The Rainbow trout, Oncorhynchus mykiss, (Figure 14) is a Pacific species from the west coast of North America. It has been introduced worldwide for aquaculture and was first transported to Europe in 1884 (MacCrimmon 1971). It was first imported to Iceland from Denmark in 1950 for aquaculture purposes (Gudjonsson 1952). Sea run O. mykiss (Steelhead trout) was first recorded in nature in 1983 in the estuary of the Fróðá river, western Iceland (Jónsson 1983). It has since then been observed in rivers and ponds in the Southwest Iceland, as the trout has escaped or been released from hatcheries and fish farms. The size and age of Steelheads caught in South Iceland indicate that they are likely escapees from aquaculture farms in the Faroe Islands. There are no evidences of natural populations in Iceland. However, the possible impact from O. mykiss is predation and competition by adults with native species especially brown trout and Arctic charr, fry and parr (Landergren 1999). 


\section{Figure 14: Oncorhynchus mykiss}

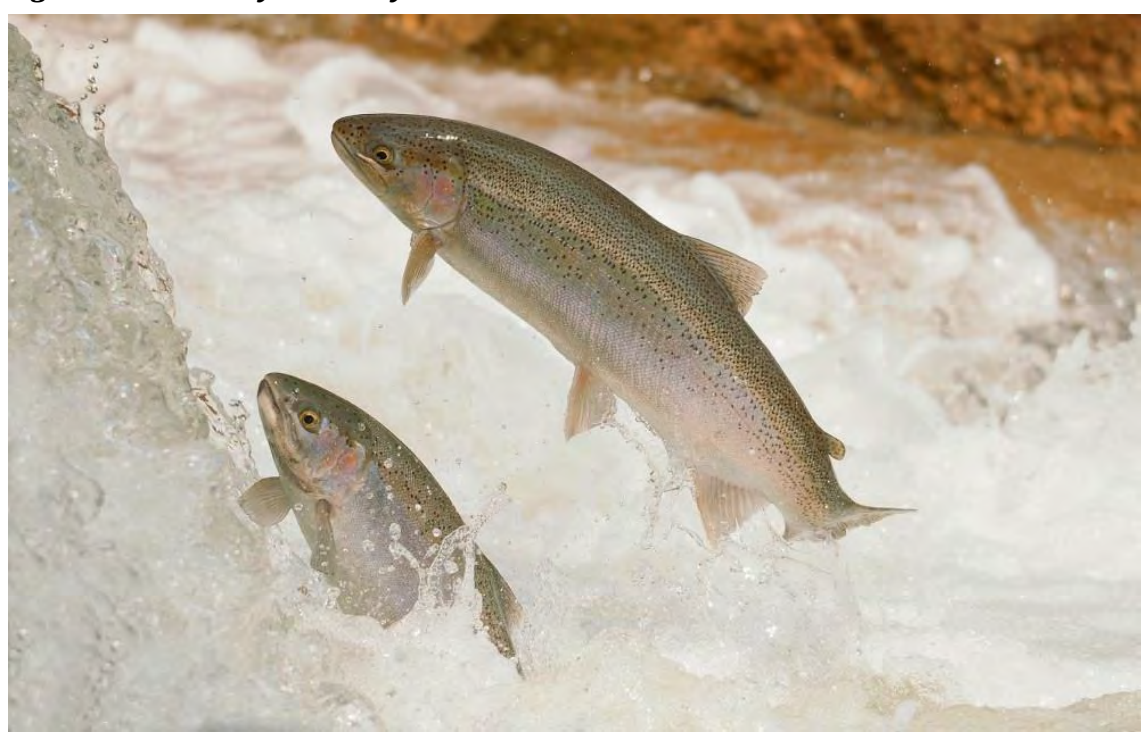

Photo: Alex Borbely

\subsection{Summary and conclusion}

Fourteen non-native marine species have been recorded in Icelandic waters in the last 58 years, nine of them in the last decade. This is a diverse group of species belonging to to phytoplankton, macroalgae, crustaceans, bivalves, tunicates and fish. Four of those species can be considered potentially invasive as they adversely affect the habitats and bioregions they invade environmentally, and/or ecologically. The Atlantic rock crab, the brown shrimp and the European flounder are then species that might become invasive in the future, as the populations seems to be healthy and are thriving well in Icelandic waters, spreading rapidly possibly to the disadvantage of other native species.

The brown seaweed Fucus serratus is the only macroalgae species that can be classified as an invasive species, as it becomes dominant part of the community by forming a canopy cover in the lower part of the shore, reducing or eliminating the cover of other canopy forming algae.

Other introduced species, still not showing invasive characteristics as the Vase tunicate Cione intestinalis and some phytoplankton species as $\mathrm{Me}$ diopyxis helysia, should be paid attention to in the future as they have become invasive elsewhere in the world where they have been introduced.

The flounder Platichthys flesus, the brown shrimp Crangon crangon and the Atlantic rock crab Cancer irroratus, were first recorded in Icelandic 
waters in 1999, 2003 and 2006 respectively and all were first found in south-western Iceland. These species spread rapidly, predate on other species in the area and compete for food and space. The brown seaweed Fucus serratus that was first observed more than 100 years ago, has spread slowly but has outcompeted other native algal species like Fucus distichus, where it grows. These species have probably been transported to Iceland in ballast water and in the case of the Fucus serratus probably with stone ballast. Most likely they have been transported from Europe, except the rock crab that came from the east coast of North-America. Most of the non-native marine species were first recorded in south-western Iceland where the oceanic traffic of large cargo vessels is most frequent and monitoring programs have been carried out for years.

The increasing sea temperature in Icelandic waters in the last two decades has changed the distribution of local fish species and made it possible for more varied group of non-native species, like the Atlantic rock crab, to invade Icelandic waters.

It is extremely difficult to eradicate non-native marine species once they have arrived. Because of the known risks of certain introductions the emphasis should be on precaution. New regulation on handling of ballast water was introduced in Iceland in 2010 to prevent introduction of alien marine species. It forbids discharge of ballast water in Icelandic jurisdiction. Hopefully this will slow down the rate of new introductions. Although ballast water is certainly an effective vector for transfer of nonnative species, other vectors such as ship hull fouling and transport of aquaculture organisms are also important and need to be addressed, but in a different way. The complete prevention of the transport and establishment of non native marine species to Iceland is probably an unrealistic dream. While potentially invasive alien species continue to arrive, understanding the process of settling and establishment of non native species and their effects on the Icelandic coastal ecosystem is necessary. Regular monitoring and case studies are badly needed.

\subsection{References}

Anonymous (2004): Hydrographic status report 2003. Report of the working group of oceanic hydrography. ICES CM 2004/C06, pp. 182.

Ansell, A.D., Comely, C.A., and Robb, L. (1999): Distribution, movements and diet of macrocrustaceans on a Scottish sandy beach with particular reference to predation on juvenile fishes. Mar Ecol Prog Ser Vol. 176, pp. 115-130.

Astthorsson, O.S., Valdimarsson, H., Gudmundsdottir, A. and Oskarsson, G.J. (2012): Climate-related variations in the occurrence and distribution of mackerel (Scomber scombrus) in Icelandic waters. ICES J Mar Sci Vol. 69 No. 7, pp. 1289-1297. 
Bax, N., Williamson, A., Aguero, M., Gonzalez, E.L., Geeves, W. (2003). Marine invasive alien species: a threat to global biodiversity. Marine Policy Vol. 27, pp. 313-323

Björnsson, A. (2011): Tegundasamsetning botndýra á hörðum botni í höfnum á Suðvesturlandi A report in Icelandic, 19 p. Háskóli Íslands, Reykjavík (in Icelandic with English summary).

Braarud, T. (1969): Pollution effect upon the phytoplankton of the Oslofjord. ICES Plankton Comm. CM 1969/L:15, 23 pp.

Brenner, M., Fraser, D., Van Nieuwenhove, K., O`Beirn, F., Buck, B.H., Mazurié, J., Thorarinsdottir, G., Dolmer, P., Sanchez-Mata, A., Strand, O., Flimlin, G., Miossec, L., Kamermans, P. (2014): Bivalve aquaculture transfers in Atlantic Europe. Part B: environmental impacts of transfer activites. Ocean and Coastal Managem (accepted for publication).

Brodie, J., C.A. Maggs, D.M. John (Eds) (2007): Green Seaweeds of Britain and Ireland. The British Phycological Society, London, 242 pp.

Campos, J. and van der Veer, H.W. (2008): Autecology of Crangon crangon (L.) with an emphasis on latitudinal trends. Oceanography and Marine Biology: An Annual Review. Aberdeen University Press/Allen \& Unwin, Aberdeen, pp. 65-104.

Carlton, I.T. and Scanlon, I.A. (1985): Progression and dispersal of an introduced alga: Codium fragiles ssp. tomentosoides (Chlorophyta) on the Atlantic coast of North America. Bot Mar Vol. 28, pp. 155-165.

Carman, M.R., Morris, J.A., Karney, R.C. and Grunden, D.W. (2010): An initial assessment of native and invasive tunicates in shellfish aquaculture of the North American east coast. J Appl Ichtyol Vol. 26, No. 2, pp. 8-11.

Chen, L.C.M., Edelstein, T. and McLachlan, J. (1969): Bonnemaisonia hamifera Hariot in nature and in culture. J Phycol Vol. 5, pp. 211-220.

Christiansen, T., Christensen, J.T., Markager, S.S., Petersen, J.K. and Mouritsen, L.T. (2006): Limfjorden i 100 år. Klima, hydrografi, næringsstoftilførsel, bundfauna og fisk i Limfjorden fra 1897 til 2003. A report from DMU Vol. 578, 85 pp.

Churchill, A.C. and Moeller, W. (1972): Seasonal patterns of reproduction in New York populations of Codium fragile (Sur.) Hariot subsp. tomentosoides (Van Goor) Silva.J Phycol Vol. 8, pp. 147-152.

Connell, L. (2000): Nuclear ITS region of the alga Heterosigma akashiwo (Chromophyta: Raphidophyceae) is identical in isolates from Atlantic and Pacific basins. Mar Biol Vol. 136, pp. 953-960.

Corbyn, Z. (2007): Atlantic invaders: The melting of Arctic sea ice is blurring the biological boundaries between Pacific and Atlantic. Nature reports - climate change Vol. 6, pp. 82-84.

Coyer, J.A., Hoarau, G., Skage, M., Stam, W.T. and Olsen, J.L. (2006): Origin of Fucus serratus (Heterokontophyta; Fucaceae) populations in Iceland and the Faroese: a microsatellite-based assessment. Eur J Phycol Vol. 41, No. 2, pp. 235-246.

Coyer, J.A., Hoarau, G., Stam, W.T. and Olson, J.L. (2007): Hybridisation and introgression in a mixed population of the intertidal seaweeds Fucus evanescens and Fucus serratus. J Evol Biol Vol. 20, pp. 2322-2333.

Crooks, J.A. and Soulé, M.A. (1999): Lag times in populations explosions of invasive species: Causes and implications. In: Sandlund, O.T., Schei, P.J., Viken, Å. (Eds.), Norway/UN Conference on Alien Species. Directorate for Nature Management and Norwegian Institute for Nature Research, Trondheim, pp. 39-46.

Doflein, F. (1900): Die dekapoden Krebse der arktischen Meere. Fauna Arctica Vol. 1, pp. 315-362. 
Dybern, B.I. (1967): The distribution and salinity tolerance of Ciona intessinalis (L.) f. typica with special reference to the waters around southern Scandinavia. Ophelia Vol. 4, pp. 207-226.

Eastwood, M.M., Donahue, M.J. and Fowler, A.E. (2007): Reconstructing past biological invasions: niche shifts in response to invasive predators and competitors. Biol Invasions Vol. 9, No. 4, pp. 397-407.

Eydal, A. (2003): Áhrif næringarefna á tegundasamsetningu og fjölda svifpörunga í Hvalfirði. Hafrannsóknastofnunin Fjölrit Vol. 94, 44 pp. (in Icelandic with English summary).

Floc'h, J.-Y. (1969): On the ecology of Bonnemaisonia hamifera in its preferred habitats on the western coast of Brittany (France). Br Phycol J Vol. 4, pp. 91-95.

Fralick, R.A. and Matthieson, A.C. (1973): Ecological studies of Codium fragile in New England, USA. Mar Biol Vol. 19, pp. 127-132.

Galil, B.S. (2009): “Taking stock: inventory of alien species in the Mediterranean sea”. Biol Invasions Vol. 11, No. 2, pp. 359-372.

Gíslason, Ó.S., Jónasson, J.P., Svavarsson, J. and Halldórsson, H.P. (2013a): Merkingar og péttleikamat á grjótkrabba við Ísland. Náttúrufræðingurinn Vol. 1-2, pp. 39-48. (In Icelandic with English summary).

Gíslason, Ó.S., Pálsson, S., McKeown, N.J., Halldórsson, H.P., Shaw, P.W. and Svavarsson, J. (2013b): Genetic variation in a newly established population of the Atlantic rock crab Cancer irroratus in Iceland. Mar Ecol Prog Ser Vol. 494, pp. 219-230.

Gíslason, Ó.S., Svavarsson, J., Halldórsson, H.P. and Pálsson, S. (2013c): Nuclear mitochondrial DNA (numt) in the Atlantic rock crab Cancer irroratus Say, 1817 (Decapoda, Cancridae). Crustaceana Vol. 86, No. 5, pp. 537-552.

Gíslason, Ó.S., Halldórsson, H.P., Pálsson, M.F., Pálsson, S., Davíðsdóttir, B. and Svavarsson, J. (2014): Invasion of the Atlantic rock crab (Cancer irroratus) at high latitudes. Biol Invasions. 13 pp. DOI 10.1007/s10530-013-0632-7.

Gudbrandsson, G.I. and Jónsson, B. (2004): Landnám, útbreiðsla og búsvæðaval nýrrar tegundar við Íslandsstrendur, ósaflundru (Platichthys flesus). Reykjavik, November 19-20, 2004. Poster.

Gudjonsson, T. (1952): Regnbogi. Veiðimaðurinn Vol. 22, pp.1-3 (in Icelandic).

Gunnarsson, K. and Galan, A. (1990): Beltaskipting pörunga í skjólsælum klettafjörum og breytingar sem verða við náttúrulegt brottnám sagpangs (Fucus serratus L.). In: Eggertsson, G., Guðmundsson, G.F., Thorláksdóttir, R., Sigmundsson, S. (Eds), Brunnur lifand vatns, Háskóli Íslands, Háskólaútgáfan, Reykjavík, pp. 81-89 (in Icelandic with English summary).

Gunnarsson, B., Asgeirsson, T.H. and Ingolfsson, A. (2007): The rapid colonization by Crangon crangon (Linnaeus, 1758) (Eucarida, Caridea, Crangonidae) of Icelandic coastal waters. Crustaceana Vol. 80, No. 6, pp. 747-753.

Gunnarsson, K. and Egilsdóttir, S. (2010): Framandi tegundir botnpörunga i sjó við Ísland. Hafrannsóknir Vol. 152, pp. 47-51 (in Icelandic with English summary).

Gunnarsson, K., Eydal, A., Ólafsdóttir, S.R. and Örnólfsdóttir, Ö.B. (2011): Svifpörungarnir Mediopyxis helysia og Stephanopyxis turris; Nýjar viðbætur við svifið við Ísland. Hafrannsóknir Vol. 158, pp. 42-47 (in Icelandic with English summary).

Hara, Y. and Chihara, M. (1987): "Morphology, ultrastructure and taxonomy of the Raphidophycean alga Heterosigma akashiwo". Bot Mag, Tokyo Vol. 100, pp. 151-163.

Hayes, K., Sliwa, C., Migus, S., McEnnulty, F. and Dunstan, P. (2005): National priority pests: part II ranking of Australian marine pests. CSIRO Marine Research, a report, 94 pp. 
Henderson, P.A. and Holmes, R.H.A. (1987): On the population biology of the common shrimp Crangon crangon (L.) (Crustacea: Caridea) in the Severn Estuary and Bristol Channel. J Mar Biol Ass U K Vol. 67, pp. 825-847.

Hollebone, A. and Hay, M. (2008): An invasive crab alters interaction webs in a marine community. Biol Invasions Vol. 10, No. 3, pp. 347-358.

Hostens, K. (2000): Spatial pattern and seasonality in epibenthic communities of the Westerschelde (Southern Bight of the North Sea). J Mar Biol Ass U K Vol. 80, pp. 27-36.

Hawkins, S.J. and Harkin, E. (1985): Preliminary canopy removal experiment in algal dominated communities low in the shore and in the shallow subtidal on the Isle of Man. Bot Mar Vol. 28, pp. 223-230.

Ingólfsson, A. (2008): The invasion of the intertidal canopy-forming alga Fucus serratus L. to south-western Iceland: Possible community effects. Est Coast Shelf Sci Vol. 77, pp. 484-490.

Joensen, J.S. and Taaning, A.V. (1970): Marine and freshwater fisheries. Zoology of the Faroes Vol. 3. No. 1, 241 pp.

Jóhannsson, M. and Jónsson, B (2007): Flundra í íslenskum vatnakerfum. Sportveiðiblaðið Vol. 97, pp. 1-2 (in Icelandic).

Jónsson, H. (1903): The marine algae of Iceland. Phaeophyceae. Bot Tidsskr Vol. 25, pp. 141-195.

Jónsson, T.D. (1983): Regnbogasilungur (Oncorhynchus mykiss), niðurstöður og greiningar á fiski veiddum í Fróða 16. september 1983. A Report, 6 p. Veidimálastofnun, Borgarnes (in Icelandic).

Jónsson, S. (1999): Temperature time series from Icelandic coastal stations. Rit Fiskideildar, Vol. 16, pp. 59-68.

Jónsson, S. and Gunnarsson K. (1975): La presence de Codium fragile (Sur.) Hariot en Island et son extension dans l'Atlantique Nord. Nova Hedwigia Vol. 16, pp. 725-732.

Jónsson, G., Pálsson, J. and Jóhannsson, M. (2001): Ný fisktegund, flundra Platichtys flesus (Linnaeus, 1758) veiðist á Íslandsmiðum. Náttúrufræðingurinn Vol. 70, No. 2 3, pp. 83-89 (in Icelandic with English summary).

Kolbenstein, M.J. (2013): Expansion of the brown shrimp Crangon crangon L. onto juvenile plaice Pleuronectes platessa L. nursery habitat in the Westfjords of Iceland. University of Akureyri, Reykjavík, 68 p.

Kraberg, A.C., Carstens, K., Peters, S., Tilly, K. and Wiltshire, K.H. (2012): The diatom Mediopyxis helysia Kühn, Hargraves \& Hallinger 2006 at Helgoland Roads: a success story?. Helgol Mar Res Vol. 66, pp. 463-468.

Kühn, S.F., Klein, G., Hallinger, H., Hargraves, P.E. and Medlin, L.K. (2006) A new diatom Mediopyxis helysia gen. nov. et sp. nov. (Mediophyceae) from the North Sea and Gulf of Main as determined from morphological and phylogenetic characteristics. Nova Hedwigia, Beiheft Vol. 130, pp. 307-323

Lambert, C.C. and Lambert, G. (2003): Persistence and differential distribution of nonindigenous acsidians in harbors of the Southern California Bight. Mar Ecol Prog Ser Vol. 259, pp. 145-161.

Landergren, P. (1999): Spawning of anadromous rainbow trout, Oncorhynchus mykiss, (Walbaum): A threat to sea trout, Salmo trutta L., populations? Fish Res Vol. 40, pp. 55-634.

McCollin, T. (2008): Observation of Mediopyxis helysia in Scottish waters. ICES CM 2008/A:10, Poster.

MacCrimmon, H.R. (1971): World distribution of rainbow trout (Salmo gairdneri). J Fish Res Board Can. Vol. 28, pp. 663-704. 
McDonald, P.S., Jensen, G.C. and Armstrong, D.A. (2001): The competitive and predatory impacts of the nonindigenous crab Carcinus maenas (L.) on early benthic phase Dungeness crab Cancer magister Dana. J Exp Mar Bio Ecol Vol. 258, No. 1, pp. 39-54.

Mack, R.N., Simberloff, D. and Lonsdale, W.M (2000): Biotic invasions: cause, epidemiology, global consequences, and control. Ecol Appl Vol. 10, pp. 689-710.

Martin, J.L. and LeGresley, M.M. (2008): New phytoplankton species in the Bay of Fundy since 1995. ICES J Mar Sci Vol. 65 No. 5, pp. 759-764.

Meier, S. and Hillebrand, H. (2012): Dominance of the invasive diatom Mediopyxis helysia (Kuhn et al., 2006) irrespective of prevailing Si:N ratios. 97th Annual Meeting of the Ecological Society of America (ESA 2012), Abstract.

Miettinen, A., Koç, N. and Husum, K. (2013): Appearance of the Pacific diatom Neodenticula seminae in the northern Nordic Seas - An indication of changes in Arctic sea ice and ocean circulation. Mar Micropaleontol Vol. 99, pp. 2-7.

Miller, R.J. (1989): Catchability of American lobsters (Homarus americanus) and rock crabs (Cancer irroratus) by traps. Can J Fish Aquat Sci Vol. 46, No. 10, pp. 1652-1657.

Molnar, J.L., Gamboa, R.L., Revenga, C. and Spalding, M.D. (2008): Assessing the global threat of invasive species to marine biodiversity. Front Ecol Environ Vol. 6, No. 9, pp. 485-492.

Muehlbauer, F., Fraser, D., Brenner, M., Van Nieuwenhove, K., Buck, B.H., Strand, O., Mazurié, J., Thorarinsdottir, G., Dolmer, P., O`Beirn, F., Sanchez-Mata, A. and Kamermans, P. (2014). Bivalve aquaculture transfers in Atlantic Europe. Part A: transfer activities and legal framework. Ocean and Coast Manage Vol. 89, pp. 127-138.

Munda, I.M. (1978): Survey of the benthic algal vegetation of the Dýrafjörður, northwest Iceland. Nova Hedwigia Vol. 29, pp. 281-403

Muus, B.J., Nielsen, P.D., Dahlström, P. and Nyström, B.O. (1997): In: Havfisk og fiskeri i Nordvesteurope. Vol. 5. Gads forlag.

Obolowski, K. and Piesik, Z. (2005): Mya arenaria (L.) in the Polish Baltic Sea coast. Baltic Coastal Zone Vol. 9, pp. 13-27.

Occhipinti-Ambrogi, A. (2007): Global change and marine communities: Alien species and climate change. Mar Poll Bull Vol. 55, pp. 342-352

Oh, C.W., Hartnoll, R.G. and Nash, R.D.M. (2001): Feeding ecology of the common shrimp Crangon crangon in Port Erin Bay, Isle of Man, Irish Sea. Mar Ecol Prog Ser Vol. 214, pp. 211-223.

Óskarsson, I. (1982): Skeldýrafána Íslands. Leiftur Reykjavík, 351 p (in Icelandic).

Padilla D.K. and Williams, S.L. (2004): Beyond ballast water: aquarium and ornamental trades as sources of invasive species in aquatic ecosystems. Front Ecol Environ Vol. 2, pp. 131-138.

Petersen, K.S., Rasmussen, K.L., Heinumeier, J. and Rud, N. (1992): “Clams before Columbus?". Nature Vol. 359, pp. 679.

Petersen, K.J., Hansen, J.W., Lauresen, M.B., Clausen, P., Carstensen, J. and Conley, D.J. (2008): Regime shift in coastal marine ecosystem. Ecological Application Vol. 18, No. 2, pp. 497-510.

Poppe, G.T. and Goto, Y. (1993): European Seashells. Vol. 2, 221 p.

Provan, J., Booth, D., Todd, N.P., Betty, G.E. and Maggs, C.A. (2008): Tracking biological invasion in space and time: elucidating the invasive history of the green alga Codium fragile using old DNA. Divers Distrib Vol. 14, pp. 342-354.

Reid, P.C., Johns, D.G., Edwards, M., Starr, M., Poulins, M. and Snoeijs P. (2007): A biological consequence of reducing Arctic ice cover: arrival of the Pacific diatom Neodenticula seminae in the North Atlantic for the first time in 800,000 years. Glob Change Biol Vol. 13, pp. 1910-1921. 
Robinson T. B., Griffiths C. L., McQuaid C. D. and Rius M. (2005): Marine Alien Species of South Africa - Status and Impacts. Afr J Mar Sci Vol. 27. No. 1, pp. 297-306.

Scheibling R.E. and Gagnon, P. (2006): Competitive interactions between the invasive green alga Codium fragile ssp. tomentosoides and native canopy-forming seaweeds in Nova Scotia (Canada). Mar Ecol Prog Ser Vol. 325, pp. 1-14.

Silva, P.A. (1955): The dichotomous species of Codium in Britain. J Mar Biol Ass U K Vol. 34, pp. 565-577.

Silva, P.A. (1957): Codium in Scandinavian waters. Sv Bot Tidsskr Vol. 51, pp. 117-134.

Smayda T.J. (2006): Scientific review on the nature and origins of harmful algal blooms in Scotland. Harmful algal bloom communities in Scottish coastal waters: relationship to fish farming and regional comparisons, a review. Paper 2006/3 The Scottish Government.

Snyder, W.E. and Evans, E.W. (2006): Ecological effects of invasive arthropod generalist predators. Annu Rev Ecol Evol S Vol. 37, pp. 95-122.

Sorte, C.J.B., Williams, S.L., and Zerebecki, R.A. (2010): Ocean warming increases threat of invasive species in a marine fouling community. Ecology Vol. 91, No. 8, pp. 2198-2204.

Stæhr, P. A., Pedersen, M. F., Thomsen, M. S., Wernberg, T. and Krause-Jensen, D. (2000): Invasion of Sargassum muticum in Limfjorden (Denmark) and its possible impact on the indigenous macroalgal community. Mar Ecol Prog Ser Vol. 207, pp. 79-88.

Stachowicz, J.J., Fried, H., Osman, R.W., and Whitlatch, R.B. (2002): Biodiversity, invasion resistance, and marine ecosystem function: reconciling pattern and process. Ecology Vol. 83, pp. 2575-2590.

Strasser, M. (1999): M. arenaria - an ancient invader of the North-Sea Coast. Helgolander Meeresun Vol. 52, pp. 309-324.

Streftaris, N., Zenetos, A. and Papathanassiou, E. (2005): Globalisation in marine ecosystems: the story of non-indigenous marine species across European seas. Oceanogr Mar Biol Annu Rev Vol. 43, pp. 419-453.

Svavarsson, J. and Dungal, P. (2008). Leyndardómar sjávarins við Ísland. Glóð, Reykjavík, 167 pp (in Icelandic).

Therriault, T.W. and Herborg, L.M. (2008): Predicting the potential distribution of the vase tunicate Ciona intestinalis in Canadian waters: informing a risk assessment. ICES J Mar Sci Vol. 65, pp. 788-794.

Thorarinsdottir, G.G. and Thordardottir, T. (1997): Vágestir í plöntusvifinu. Náttúrufræðingurinn Vol. 67, No. 2, pp. 67-76 (in Icelandic).

Thorarinsdottir, G.G., Ólafsson, M.F. and Kristjánsson, T.Ö. (2007): Lostætur landnemi. Náttúrufræðingurinn Vol. 75 No. 1, pp. 34-40 (in Icelandic).

Tiews, K. (1970): Synopsis of biological data on the common shrimp Crangon crangon (Linnaeus, 1758). FAO Fish Rep Vol. 4, pp. 1167-1224.

van der Veer, H.W., Feller, R.J., Weber, A. and Witte, J.I.J. (1998): Importance of predation by crustaceans upon bivalve spat in the intertidal zone of the Dutch Wadden Sea as revealed by immunological assays of gut contents. J Exp Mar Biol Ecol Vol. 231, pp. 139-157.

Wallentinus, I. and Nyberg, C.D. (2007): Introduced organisms as habitat modifiers. Mar Poll Bull Vol. 55, pp. 323-332

Weis, J.S. (2010): The role of behavior in the success of invasive crustaceans. Mar Freshw Behav Physiol Vol 43, No. 2, pp. 83-98.

Welcomme, R.L., (1988): International introductions of inland aquatic species. FAO Fish Techn Paper Vol. 294, p. 318. 
Wennhage, H. (2002): Vulnerability of newly settled plaice (Pleuronectes platessa L.) to predation: effects of habitat structure and predator functional response. J Exp Mar Biol Ecol Vol. 269, pp. 129-145.

Williams, A.B. (1984): Shrimps, lobsters, and crabs of the Atlantic coast of the eastern United States, Maine to Florida. Smithsonian Institution Press, Washington, D. C., 550 pp.

Williams, S.L. and Smith, J.E. (2007): A global review of the distribution, taxonomy, and impacts of introduced seaweeds. Annu Rev Ecol Evol S Vol. 38, pp. 327-59. 

Section 4:

Policy-oriented Invasive Species

Case Studies 



\section{Optimizing policies to combat aquatic invasive species}

Jarkko K. Niemi, MTT Agrifood Research Finland, Helsinki, Finland; Kari Hyytiäinen, MTT Agrifood Research Finland and University of Helsinki, Department of Economics and Management, Helsinki, Finland; Maiju Lehtiniemi, Finnish Environment Institute, Marine Research Centre, Helsinki, Finland; Kimmo Tikka, Finnish Meteorological Institute, Helsinki, Finland.

\subsection{Introduction}

Invasive species are a major threat to aquatic ecosystems. They can result in biodiversity loss and adverse environmental, economic and social impacts (Leppäkoski et al., 2002; Occhipinti-Ambrogi and Savini, 2003; Pimentel et al., 2005). Arctic areas are particularly sensitive to distortions and climate change can further emphasize their sensitivity by allowing increased human activities in the area. International ship traffic from Europe to Asia via the Northeast route in combination with the warming of the oceans can increase invasions of species in the Arctic areas. Ballast water, sediments and ship fouling associated with ship traffic provide species with routes to spread quickly over long distances in a manner which is not in line with their natural pattern of spread. According to Molnar et al. (2008), 31\% of all identified aquatic invasions have occurred via ballast water.

Thermal pollution due to increased human activity in the Nordic regions is a largely neglected issue. Establishments of new heat-producing infrastructures can increase the temperature of water at least locally and hence provide a place for aquatic invasive species to settle down in the Arctic. Thermal pollution near the warm water discharge outlets of power plants are typical gateways for aquatic invasive species to enter an area from warmer environments.

Cooperation between stakeholders and preventive abatement (Fernandez 2007), as well as behaviour of stakeholders are important for the choice of and the effectiveness of policies to control invasive species 
(Levente and Phaneuf, 2009). It can be very difficult and costly, if possible at all, to eradicate aquatic species which have been established in a region. International Maritime Organization (IMO) has suggested improvements in ballast water treatments to reduce the risk of invasion. However, for a decision-maker choosing measures to combat invasive species it is important to have information about measures which are beneficial. It is also important to notice that the measures are not chosen separately. Benefits that can be obtained through more intensive monitoring or preventive measures depend on the damage that can be avoided. As adaptation and eradication are ways to reduce the losses caused by invasive species, they can also affect the optimal monitoring and prevention policies, and hence should be studied simultaneously.

Asian clam (Corbicula fluminea) is a small bivalve originating from Asia, from where it has been spreading rapidly in recent decades (Darrigran, 2002; McMahon, 2002; Sousa, 2008). The clam is a freshwater species which tolerates salinities up to 13 PSU (Practical Salinity Units) and which aggressively outcompetes native invertebrates (Karatayev et al., 2003), fouls water intake pipes (Eng, 1979), alters benthic habitats (Hakenkamp et al., 2001) and reduces the recreational value of beaches (Pimentel et al., 2005).

Invasive species in the context of power plant investments have been studied previously (e.g. Leung et al., 2002), but research in the context of cold water is sparse. The goal of this study was to conduct an ex-ante analysis of management (prevention, eradication, control and adaptation) of Asian clam in an area close to the harbor of Kemi in Northern Finland. Because of thermal water pollution expected from a planned nuclear power plant, the environment was potentially suitable for the Asian clam.

Our analysis is built on a previously published stochastic dynamic programming model by Hyytiäinen et al. (2013). Earlier results are enriched through additional analysis with respect to some of the most critical model parameters, which are jointly minimised. The model accounts for both private and social costs of Asian clam and control measures. Our analysis contributes to the previous knowledge by taking into account how new information about the state of a clam invasion and associated risks affects the optimal management policy. 


\subsection{Summary}

Invasive species can cause substantial damages to various industries. Ballast water, sediments and ship fouling associated with ship traffic provide species with routes to spread quickly over long distance to the Nordic conditions. In this paper we examine the control of Asian clam, an invasive aquatic species. Analysis revealed a set of relevant policies. This set includes preventive policies aimed at preventing an invasion, and to some extent also to adapting to the invasion and eradicating the clam from the region. Also, mitigative policies involved efforts on the timely detection of clam population and preventing an established population from growing thereafter or from causing excessive damages. Interestingly, monitoring and chemical antifouling as preventive measures (if taken before any invasion) could be substitutes. Adaptive policies focused on reducing the negative consequences of the invasion for the power plant without paying too much attention to prevention and monitoring. Finally, in eradication policies efforts were put on both eradication and prevention of clam invasion. These policies benefit stakeholders differently as the costs are borne by different stakeholders. Policies which focus on adaptation involve the power company over other stakeholders more than other policies. This is because adaptation focuses on mitigating failures at the power plant whereas other policies put more emphasis on reducing the clam stock.

\subsection{The dynamic programming model}

\subsubsection{Case-study area}

Our case study area is the water discharge area of a nuclear power plant, which was planned to be built in Karsikkoniemi, on the northeastern shore of the Bothnian Bay of the Baltic Sea. The place is located next to the Ajos harbour of the town of Kemi. The harbour is served with both scheduled and irregular freight traffic from European ports which are contaminated by the Asian clam. During the course of this this study the power company decided to install the power plant in another location.

Kemi is located in the northernmost corner of the Baltic Sea, where the waters are too cold for Asian clam to survive in most winters. However, heat pollution of planned power plant would have provided the Asian clam with more favourable conditions to become established. We have estimated that there would have been 200 ha of seabed where the clams could reproduce (Ilus, 2009). 


\subsubsection{Objective function}

As our analysis is based on a previously presented model, we repeat here only the generic idea of the model and information necessary to interpret the results. The details of how the utility-maximising management policy was optimized are available in Hyytiäinen et al. (2013). Regarding the details the reader is recommended to consult the article. Given the decision to build a nuclear power plant, the social planner adjusts the prevention, mitigation and adaptation measures such that the total discounted costs from damage to shipping, power production, and people living in the area are minimized over time.

The Bellman (1957) equation of the problem is of the form:

$$
\begin{aligned}
& V_{t}\left(\mathbf{x}_{t}\right)=\max _{\alpha, \beta, \gamma, \delta}\left(R_{t}\left(\mathbf{x}_{t}, \alpha, \beta, \gamma, \delta\right)+b V_{t+1}\left(\mathbf{x}_{t+1}\right)\right) \text { for } t=1, \ldots, \mathrm{T} \\
& \text { s.t. } \mathbf{x}_{t+1}=\mathbf{x}_{t}+g\left(\mathbf{x}_{t}, \alpha, \beta, \gamma, \delta\right) \\
& \quad \mathbf{x}_{t} \text { is given }
\end{aligned}
$$

$V_{t}\left(\mathbf{x}_{t}\right)$ represents the minimized value of the risk of clam invasions and preventive measures, $t$ is the time index and $T$ is the total number of time periods considered, $\mathbf{x}_{t}$ is the vector of state variables, which contains the information on whether an invasion has been observed and what is the size of the invasion, $R_{t}$ refers to the costs incurred during the period $t, b$ is the discount factor (i.e. one minus annual discount rate), $\alpha, \beta, \gamma$ and $\delta$ are decision variables, and the constraints represent the transition equations for the state variables. As decision variables are optimise simultaneously, the model actually solve the optimal combination of measures. The optimal set of measures over time and across state space is called the optimal policy. The evolution of state variables over time is a stochastic process such that the clam population may or may not occur in a given year, the rate of population growth can vary and also the detection time of the population can vary.

The development of the clam population in the heat pollution zone is described by a stage-structured model (e.g. Getz and Haight, 1989). Recruitment and mortality functions define the growth and the proportion of clams removed from the population each year. Each year, the number of clams is reduced due to natural mortality, catastrophic mortality due to harsh weather condition, density-dependent mortality, i.e. mortality rate increasing with the size of clam population (due to competition on food and space), and mortality due to control effort $(\gamma)$. 
The size of clam stock is modelled by using 36 levels of stock describing the biomass of the clam population. The first class represents the situation before invasion with zero clam individuals and the thirty sixth represents the maximum carrying capacity of the area. Discovery of a clam invasion, should it occur, is expressed using a binary state variable which depends on the stock size and the monitoring effort.

\subsubsection{Decision variables}

Measures of prevention, eradication, control, and adaptation as proposed by Finnoff et al. (2010) were examined. The management of an invasion which has not yet been detected cannot be distinguished from the case where there is no invasion at all.

We consider four decision variables. Firstly, the ballast water from vessels coming from contaminated areas to Ajos harbour can be treated $(\alpha)$ in order to reduce the probability of invasion. Secondly, monitoring activities $(\beta)$ are expected to increase the probability of detecting the invasion should it be realised. Thirdly, the clam population can be eradicated by the means of suffocation $(\gamma)$, i.e. by covering the sea bed with plastic mats to kill the clam population. Fourthly, chemical antifouling system can be established at the nuclear power plant to reduce the probability of cooling water pipelines becoming clogged by the clam $(\delta)$.

\subsubsection{Parameter values}

We simulated a baseline scenario, which was parametrized similarly to Hyytiäinen et al. (2013), and thereafter altered probability and price parameters from the baseline to examine changes in the optimal management policy. The baseline cost of ballast water treatment is EUR 1,450 per ship (Seakleen ${ }^{\circledR}$ biocide, Chattopadhyay et al., 2004; Wright et al., 2007) mulitiplied by 300 ships coming from the contaminated areas. Monitoring costs due to weekly water and sediment samples are EUR 8,000 per year. The suffocation of clams by plastic mats is assumed to be EUR 18.2 per $\mathrm{m}^{2}$ for the 5 ha closest to the shore, and EUR 25.2 for other areas. The costs of chemical antifouling are EUR 50,000 per year (Phillips et al., 2005). The shutdown of power plant due to clogging, if it occurs, is set at EUR 4,080,000 (Jalarvo, 2010). The value of lost recreation services due to full clam invasion for the 20,000 adults living in the area is set at EUR 50 per person per year (cf. Nunes and van den Bergh, 2004; McIntosh et al. 2010). Based on Gaffield et al. 
(2003) and Dwight et al. (2005), the maximum human health damages are set at EUR 100,000 per year.

The probability of invasion is set at 0.05 without and 0.005 with ballast water treatment (Port of Kemi, 2012). The probability of detecting a clam invasion increases with the stock size and follows a sigmoidal (Sshaped) distribution as defined by Hyytiäinen et al. (2013, Appendix). Clam mortality rate due to the proportion of sea bed covered by plastic mats decreased with the stock size. The probability of additional service breaks is higher with than without chemical antifouling and decreases linearly with the size of clam. The simulations reported here were conducted for $\mathrm{T}=100$ years period.

\subsection{Results}

\subsubsection{Optimal policies under different costing scenarios}

The baseline scenario represents a default situation and other scenarios are compared to it. In tables 1 to 3 the column "Cost 1 " refers to the baseline scenario. The net costs of risk of Asian clam invasion in the vicinicity of the planned nuclear power plant were simulated to amount almost EUR 5 million when discounted over the 100 years time horizon. The costs are substantially higher if an invasion is realised and also the timing on invasion impact eventual costs. In the baseline scenario the model suggests to implement the monitoring programme, but not ballast water treatment in cases where an invasion either does not exist or it has not yet been observed (Table 1). When an invasion is detected, the model suggests reducing the monitoring effort (result not shown) and starting to use chemical antifouling and suffocation as methods to reduce the invasion and damage caused by it (Tables 2 and 3). This result is due to the fact that once an invasion has taken place, measures are needed to control the damages. Then the marginal benefits associated with monitoring decrease as possible new invasion would not spread uncontrolled due to measures that are already in place due to the current invasion.

The current size of invasion that has been observed also has an impact on the optimal mitigation and adaptation policy. A small invasion in Tables 2 and 3 is defined as observed clam population falling in any of clam stock size levels 1 to 10, and the percentages in Tables 2 and 3 refer to an index of average use calculated across these ten levels. In the event of a binary variable, the average use simply refers to the percent- 
age of classes using the measure. In the event of continuous variables the extent of use in each individual class affects the result because the range of use in each individual class can range from zero (not used at all) to $100 \%$ (used at up to the maximum extent) in that class.

Medium-sized and large invasions refer to clam stock size levels 11 to 20 and 21 to 30, respectively. When a small invasion is detected, the model suggests implementing chemical antifouling in $80 \%$ of classes and covering a small core area of sea bed with plastic to suffocate the clams which have already been established. By contrast, if medium-sized or large invasion is observed, then the policy of suffocation is abandoned and the efforts are out on preventing power plant failure by chemical antifouling. In the event of a large outbreak, even monitoring effors are reduced to a minimum. These results are related to the view that once an invasion is large enough, it becomes very difficult and costly to eradicate it.

Next, the role of costs associated with each measure is examined. As Tables 2 and 3 show, the optimal policy was sensitive to assumptions regarding the costs. Decreasing the costs of measures can lead to more effective mitigation measures to be used and smaller costs to be expected due to the risk of Asian clam invasion. The analysis is carried out by reducing the costs of each measure by $30 \%$ (column "Cost 0.7 " in Tables 1 to 3), by $60 \%$ ("Cost 0.4 ") or by $90 \%$ ("Cost 0.1 "), while keeping the costs of other measures at the baseline level (i.e. the change in each cost ceteris paribus). When the costs of ballast water treatment decrease, already a $30 \%$ decrease is enough to provide incentives for the decision-maker to stop monitoring and start ballast water treatments. However, since time needed to detect an invasion is then expected to increase, chemical antifouling is to be used jointly with ballast water treatment. The result may seem surprising, but when taking into account that the costs of antifouling are only EUR 50,000 per year, it is a rational measure to reduce damages that may occur if an invasion takes place. Hence, these two measures are complements and monitoring is a substitute for them.

As monitoring was implemented already in the baseline scenario, it will be applied also at lower costs levels of monitoring activity. When the costs of suffocation by plastic decrease, it can become a measure that is used in small amounts also before observing an invasion. However, Table 1 suggests that this would require substantial reductions $(-90 \%$ in Table 1) in the costs of this measure. This is quite expected result as the measure is costly and the benefits are obtainable only when an invasion has occurred. Should suffocation be used as a preventive measure, it could provide incentives to stop monitoring activities and ballast water treatment and chemical antifouling could substitute for monitoring. 
Next we examine the impact of cost parameters on the use of suffocation by plastic in the event that an invasion has been observed. These results are highlighted in Table 2. In the baseline scenario, suffocation method is applied only in the event of a small invasion and even then it is used in very small amounts ( $<6 \%$ of the total area, on average $1 \%$ of area). When the costs of suffocation decrease dramatically (by $90 \%$ in Table 2), the measure becomes widely used as all the area will then be covered. In other cases only small areas are to be covered by plastic. While monitoring costs did not affect the use of suffocation, a decrease in the costs of ballast water treatment increased the use of suffocation method a little. Chemical antifouling is a substitute for suffocation as decreasing the cost of chemical antifouling would reduce the use of suffocation.

Table 3 represents the impact of cost parameters on the use of chemical antifouling during an invasion. The size of an outbreak has a clear impact on the use of antifouling. Table 3 suggests that chemical antifouling would be used in almost all cases where the outbreak is either medium-sized or large. In the event of a small outbreak, a decrease in the costs of antifouling measure will also increase the rate of use close to $100 \%$. The substitution between suffocation and antifouling can be seen also here. When the costs of suffocation decrease substantially (by $90 \%$ in Table 3), the use of chemical antifouling also decreases in all outbreak size categories, although the decrease is smaller the larger the outbreak is. Finally, decreasing the costs of ballast water treatment or monitoring did also to some extent reduce the use of chemical antifouling in the event of a small invasion. 
Table 1. The impact of reducing the cost of each measure by $30 \%$ (Cost 0.7 ), $60 \%$ (Cost 0.4 ) or $90 \%$ (Cost $\mathbf{0 . 1}$ ) ceteris paribus from the baseline (Cost 1 ) level on the use of each four measures when no invasion has been observed

\begin{tabular}{lrrrr} 
Costs of ballast water treatment & Cost $\mathbf{0 . 1}$ & Cost $\mathbf{0 . 4}$ & Cost $\mathbf{0 . 7}$ & Cost $\mathbf{1}$ \\
Ballast water treatment & Yes & Yes & Yes & No \\
Monitoring & No & No & No & Yes \\
Suffocation by plastic & No & No & No & No \\
Chemical antifouling & Yes & Yes & Yes & No \\
Costs of monitoring & Cost $\mathbf{0 . 1}$ & Cost $\mathbf{0 . 4}$ & Cost $\mathbf{0 . 7}$ & Cost $\mathbf{1}$ \\
Ballast water treatment & No & No & No & No \\
Monitoring & Yes & Yes & Yes & Yes \\
Suffocation by plastic & No & No & No & No \\
Chemical antifouling & No & No & No & No \\
Costs of suffocation costs & Cost $\mathbf{0 . 1}$ & Cost $\mathbf{0 . 4}$ & Cost $\mathbf{0 . 7}$ & Cost $\mathbf{1}$ \\
Ballast water treatment & Yes & No & No & No \\
Monitoring & No & Yes & Yes & Yes \\
Suffocation by plastic & Yes & No & No & No \\
Chemical antifouling & Yes & No & No & No \\
Costs of chemical antifouling & Cost $\mathbf{0 . 1}$ & Cost $\mathbf{0 . 4}$ & Cost $\mathbf{0 . 7}$ & Cost 1 \\
Ballast water treatment & No & No & No & No \\
Monitoring & No & Yes & Yes & Yes \\
Suffocation by plastic & No & No & No & No \\
Chemical antifouling & Yes & No & No & No \\
\hline
\end{tabular}

Table 2. The extent of using* suffocation as an eradication measure after a small, medium-size or large invasion has been observed by the by the cost level** of each measure

\begin{tabular}{|c|c|c|c|c|}
\hline Costs of ballast water treatment & Cost 0.1 & Cost 0.4 & Cost 0.7 & Cost 1 \\
\hline Small invasion & $3 \%$ & $3 \%$ & $2 \%$ & $1 \%$ \\
\hline Medium-size invasion & $3 \%$ & $3 \%$ & $2 \%$ & $0 \%$ \\
\hline Large invasion & $2 \%$ & $1 \%$ & $0 \%$ & $0 \%$ \\
\hline Costs of monitoring & Cost 0.1 & Cost 0.4 & Cost 0.7 & Cost 1 \\
\hline Small invasion & $1 \%$ & $1 \%$ & $1 \%$ & $1 \%$ \\
\hline Medium-size invasion & $0 \%$ & $0 \%$ & $0 \%$ & $0 \%$ \\
\hline Large invasion & $0 \%$ & $0 \%$ & $0 \%$ & $0 \%$ \\
\hline Costs of suffocation costs & Cost 0.1 & Cost 0.4 & Cost 0.7 & Cost 1 \\
\hline Small invasion & $100 \%$ & $1 \%$ & $0 \%$ & $1 \%$ \\
\hline Medium-size invasion & $100 \%$ & $0 \%$ & $0 \%$ & $0 \%$ \\
\hline Large invasion & $100 \%$ & $0 \%$ & $0 \%$ & $0 \%$ \\
\hline Costs of chemical antifouling & Cost 0.1 & Cost 0.4 & Cost 0.7 & Cost 1 \\
\hline Small invasion & $0 \%$ & $0 \%$ & $0 \%$ & $1 \%$ \\
\hline Medium-size invasion & $0 \%$ & $0 \%$ & $0 \%$ & $0 \%$ \\
\hline Large invasion & $0 \%$ & $0 \%$ & $0 \%$ & $0 \%$ \\
\hline
\end{tabular}

*Percentage of use refers to an index of average use calculated across the relevant invasion size classes. Zero percentage of use refers to the measure not being used at all in any relevant size class, and $100 \%$ refers to the measure being used to the maximum extent in all relevant size classes. Small invasion represents classes 1 to 10 , medium-sized invasion classes 11 to 20 and large invasion classes 21 to 36 (36 is the maximum).

**The cost of each measure is reduced by $30 \%$ (Cost 0.7 ), $60 \%$ (Cost 0.4 ) or $90 \%$ (Cost 0.1 ) ceteris paribus from the baseline (Cost 1 ) level. 
Table 3. The extent of using* chemical antifouling as an adaptation measure after a small, medium-size or large invasion has been observed by the costs** of each measure

\begin{tabular}{|c|c|c|c|c|}
\hline Costs of ballast water treatment & Cost 0.1 & Cost 0.4 & Cost 0.7 & Cost 1 \\
\hline Small invasion & $40 \%$ & $50 \%$ & $60 \%$ & $80 \%$ \\
\hline Medium-size invasion & $100 \%$ & $100 \%$ & $100 \%$ & $100 \%$ \\
\hline Large invasion & $100 \%$ & $100 \%$ & $100 \%$ & $100 \%$ \\
\hline Costs of monitoring & Cost 0.1 & Cost 0.4 & Cost 0.7 & Cost 1 \\
\hline Small invasion & $60 \%$ & $70 \%$ & $70 \%$ & $80 \%$ \\
\hline Medium-size invasion & $100 \%$ & $100 \%$ & $100 \%$ & $100 \%$ \\
\hline Large invasion & $100 \%$ & $100 \%$ & $100 \%$ & $100 \%$ \\
\hline Costs of suffocation costs & Cost 0.1 & Cost 0.4 & Cost 0.7 & Cost 1 \\
\hline Small invasion & $20 \%$ & $80 \%$ & $80 \%$ & $80 \%$ \\
\hline Medium-size invasion & $10 \%$ & $100 \%$ & $100 \%$ & $100 \%$ \\
\hline Large invasion & $47 \%$ & $100 \%$ & $100 \%$ & $100 \%$ \\
\hline Costs of chemical antifouling & Cost 0.1 & Cost 0.4 & Cost 0.7 & Cost 1 \\
\hline Small invasion & $90 \%$ & $90 \%$ & $90 \%$ & $80 \%$ \\
\hline Medium-size invasion & $100 \%$ & $100 \%$ & $100 \%$ & $100 \%$ \\
\hline Large invasion & $100 \%$ & $100 \%$ & $100 \%$ & $100 \%$ \\
\hline
\end{tabular}

*Percentage of use refers to an index of average use calculated across the relevant invasion size classes. Zero percentage of use refers to the measure not being used at all in any relevant size class, and $100 \%$ refers to the measure being used to the maximum extent in all relevant size classes. Small invasion represents classes 1 to 10 , medium-sized invasion classes 11 to 20 and large invasion classes 21 to 36 ( 36 is the maximum).

**The cost of each measure is reduced by $30 \%$ (Cost 0.7 ), $60 \%$ (Cost 0.4 ) or $90 \%$ (Cost 0.1 ) ceteris paribus from the baseline (Cost 1 ) level.

\subsubsection{The impact of probability of invasion, monitoring and preventive measure}

Next we examine the impact of the probability of invasion and measures to reduce the probability. Table 4 represents the use of four studied measures conditional on four different scenarios where the probability of introducing the clam in the study area is as in the baseline scenario, or alternatively $-60 \%,-30 \%$ or $+30 \%$ compared to the baseline scenario. Preventive measures behave quite robustly within the studied range of probabilities. Monitoring is used in most situations. However, when the probability of introduction is decreased by $60 \%$, then monitoring is stopped and ballast water treatment and chemical antifouling are used instead. The result is related to the assumption that the probability of introduction is affecting also the size of invasion. When the probability of invasion is low enough, the benefits from timely detection of Asian clam are reduced and preventive measures are used instead.

The probability of invasion also has a small impact on adaptation and eradication as a smaller probability decrease the use of chemical antifouling and increase the use of suffocation by plastic in some cases where a small invasion has been observed (Table 4). 
If policies are able to decrease the probability of invasion, they will benefit also the society (Figure 1). By contrast, the society can suffer losses when the probability of invasion increases. However, when the probability is large enough, more effective measures might be used to control the risks and thus the damages could be limited up to a level.

More effective measures to control the risk of invasive species have been suggested. In the baseline scenario ballast water treatment and monitoring were voluntarily taken up. If monitoring would be a mandatory measure at all possible states of nature and at all times, the costs of Asian clam risk would increase only a little. In addition, monitoring was chosen frequently in the baseline scenario. This shows that implementing monitoring activities would not cause much extra burden to the society. By contrast, if ballast water treatment would be mandatory at all possible states of nature and at all times, the costs of Asian clam risk were $53 \%$ higher than in the baseline scenario (Figure 2). Mandatory ballast water treatment resulted in significant reduction in monitoring activities, chemical antifouling to be used both before and during an invasion, and suffocation of clams by plastic to be applied more frequently as an eradication measure. These results suggest that when preventive measures are more efficient, they can change the marginal benefits from eradication and hence provide incentives to put more effort on eradication of Asian clam. Regulations enforcing ballast water treatments could therefore have both negative (extra costs) and positive (more effort on eradication) spillovers to the stakeholders.

Finally, if both monitoring and ballast water treatment were mandatory, the costs of Asian clam risk were approximately 2.5-fold compared to the baseline scenario. Enforcing both measures could therefore cause extra economic losses to the society. As a consequence of enforcing both measures, suffocation by plastic would be used more frequently and chemical antifouling less frequently in the event of a small invasion. 
Table 4. The use of mitigative, preventive, adaptive and eradicative measures (yes or no) before an invasion has been observed, and the use of eradication and adaptation measures after a small, medium-sized or large invasion has been observed by the probability of invasion*

\begin{tabular}{|c|c|c|c|c|}
\hline Probability of invasion & $-60 \%$ & $-30 \%$ & Baseline & $+30 \%$ \\
\hline \multicolumn{5}{|c|}{ Before observing the invasion } \\
\hline Ballast water & Yes & No & No & No \\
\hline Monitoring & No & Yes & Yes & Yes \\
\hline Suffocation & No & No & No & No \\
\hline Chemical use & Yes & No & No & No \\
\hline \multicolumn{5}{|c|}{ When a small invasion has been observed } \\
\hline Suffocation & $2 \%$ & $2 \%$ & $1 \%$ & $0 \%$ \\
\hline Chemical antifouling & $60 \%$ & $60 \%$ & $80 \%$ & $90 \%$ \\
\hline \multicolumn{5}{|c|}{ When a medium-sized invasion has been observed } \\
\hline Suffocation & $1 \%$ & $0 \%$ & $0 \%$ & $0 \%$ \\
\hline Chemical antifouling & $100 \%$ & $100 \%$ & $100 \%$ & $100 \%$ \\
\hline \multicolumn{5}{|c|}{ When a large invasion has been observed } \\
\hline Suffocation & $0 \%$ & $0 \%$ & $0 \%$ & $0 \%$ \\
\hline Chemical antifouling & $100 \%$ & $100 \%$ & $100 \%$ & $100 \%$ \\
\hline
\end{tabular}

*Baseline probability, $+30 \%,-30 \%$ or $-60 \%$ from the baseline.

Percentages of use in the lower part of the table refer to an index of use calculated across the relevant invasion size classes. Zero percentage of use refers to the measure not being used at all in any relevant size class, and $100 \%$ refers to the measure being used to the maximum extent in all relevant size classes. Small invasion represents classes 1 to 10 , medium-sized invasion classes 11 to 20 and large invasion classes 21 to 36 ( 36 is the maximum).

Figure 1: The impact of adjusting probability of invasion on the costs incurred by the invasion and monitoring, prevention, mitigation, and adaptation when simulated over a hundred-years time horizon

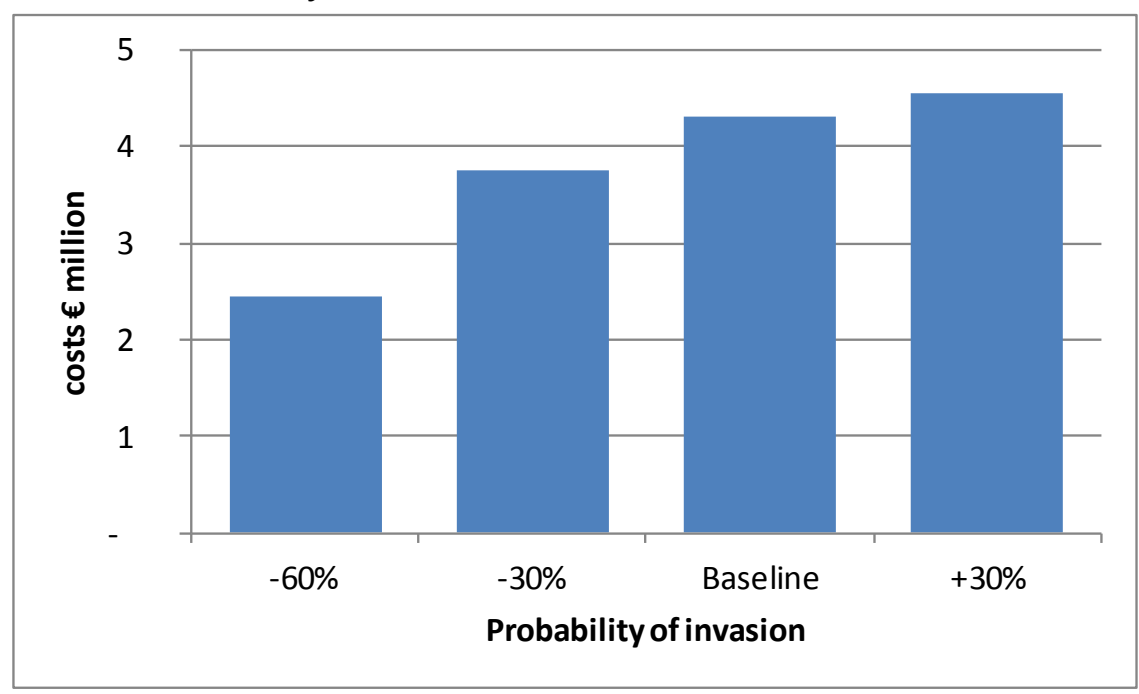


Figure 2:The impact of baseline policy* and policies where monitoring, ballast water treatment or both are mandatory on the costs (the negative of the value function) over a hundred-years time horizon

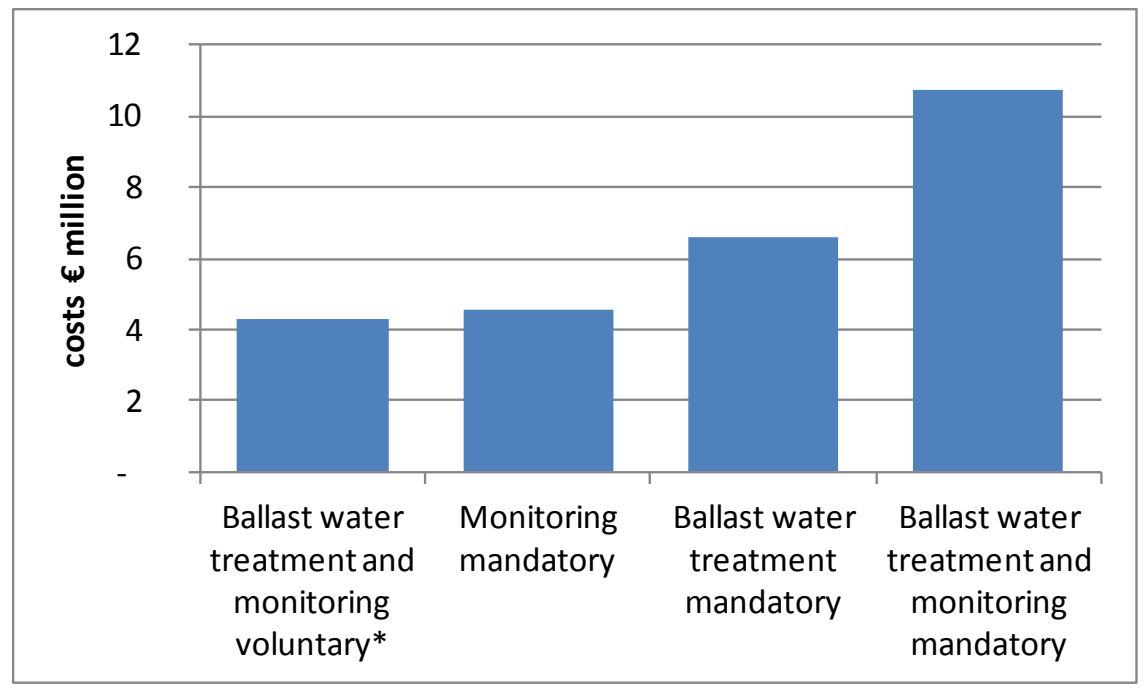

\subsection{Discussion}

In this study we have simulated the choice of prevention, monitoring, eradication, and adaptation measures regarding the management of Asian clam invasion. The management measures can help to narrow down the distribution of damages as they can reduce the likelihood of the most severe damages. Each management measure is justified if it can provide net savings in social costs. Although each measure can be chosen at any time and at any state of nature, monitoring and ballast water treatment for instance make the most sense before an invasion has been detected as they speed up the detection process and reduce the probability on introducing species into the region.

With the baseline parameter values it was optimal for the society to invest in continuous monitoring of the area before any invasion and thus speed up the detection process, and in addition to invest in ensuring that operational failures at the power plant are minimal after an invasion. In this case, the society would not invest in preventive measures, aim at reducing the spread of population during an invasion, or engage in other activities. However, a reduction in the unit cost of ballast water treatment can change the optimal policy: treatment, which reduces the probability of clams being introduced into the area reduces the expected damage. The treatment is taken into consideration jointly with preventing damages with chemical antifouling, but the monitoring policy is abandoned. Ballast 
water treatment also becomes economically attractive if ballast water treatment reduces the probability of invasion enough.

Analysis with regards to the costs of control measures revealed a set of policies to address the risk of invasive species. Preventive policies are aimed at preventing an invasion, and to some extent also to adapting to the invasion and eradicating the clam from the region. In mitigative policies efforts were put on the timely detection of clam population and preventing an established population from growing thereafter or from it causing excessive damages. Interestingly, monitoring and chemical antifouling as preventive measures (if taken before any invasion) can be substitutes. Adaptive policies focused on reducing the negative consequences of the invasion for the power plant without paying too much attention to prevention and monitoring. Finally, in eradication policies efforts were put on both eradication and prevention of clam invasion. These policies benefit stakeholders differently as the costs are borne by different stakeholders. Policies which focus on adaptation prefer the power company over other stakeholders more than other policies. This is because adaptation focuses on mitigating failures at the power plant whereas other policies put more emphasis on reducing the clams.

Monitoring is a convenient standard policy. Eradication of the clam is quite problematic as it is challenging and costly. Hence, it is fair to ask whether the harm done by invasion is permanent and whether the costs should be appraised accordingly. It was assumed that the invading clam population remains within the boundaries of the heat pollution zone. However, if the clam establishes to the warm water area and is able to adapt to the abiotic conditions of the surrrounding ecosystem, it may gradually spread outside of the warm water area and survive there as well. This has been observed in Finland with Conrad's false mussel (Mytilopsis leucophaeata), which survived many years only in the warm water area outside a nuclear power plant in the eastern Gulf of Finland, but has now adapted to the system and spread to natural parts of the Gulf of Finland ecosystem. In addition, warming climate may make it easier for the clam to adapt to the Nordic conditions in the future. If the clam is able to spread to larger area, suffocation by plastic mats may become impracticable. If the goal of a policy is to remain free of Asian clam, then eradication could be supported by enforcing also mitigative measures as that way the benefits from eradication would increase. However, such a policy could increase the costs to the society. A public policy also involves transaction costs, which we have not examined. The role of trasaction cost could be a topic for further research. Another aspect is that the Asian clam survives well in fresh water (cf. Sousa, 2008), and the 
species might be able to spread gradually to one of the 188,000 lakes in Finland. This aspect may also need to be assessed if the lakes have environments that are suitable to the Asian clam to settle down.

Ship traffic is a major risk factor for such invasion both in the Baltic Sea (Zaiko et al., 2011) and the Arctic. The effect of climate change on introduction of invasive species can be boosted by thermal pollution. This requires that any plans involving thermal pollution should also evaluate the risks associated with invasive species (cf. European Commission, 2003). Investing in preventive, mitigative or adaptive measures when facing the risk of invasions by invasive species is an important decision for a society.

There are various approaches to model invasive species (e.g. Perry and Enright, 2007; Bogich and Shea, 2008; Kaiser and Burnett, 2010; Leung et al., 2002) which can have benefits in other types of decision situations. Our framework considers simultaneously the optimal allocation of effort between pre- and post-invasion measures. This is an important methodological issue because prevention and treatment choices do not always, if ever, separate. Our approach is convenient also because it accounts for uncertainty about future and for the option to adjust invasive species control policy according to the current situation, and it accounts for state-specific marginal costs and benefits. The framework as such is applicable to other ecosystems in the Arctic although the parameterizations must be adjusted case-by-case.

\subsection{References}

Bellman, R. (1957): Dynamic Programming. Princeton University Press, New Jersey, pp. 339.

Bogich, T. and Shea, K. (2008): A state dependent model for the optimal management of an invasive metapopulation. Ecol Applications 18, pp. 748-761.

Chattopadhyay, S., Hunt, C., Rodgers, P., Swiecichowski, A. and Wisneski, C. (2004): Evaluation of biocides for potential treatment of ballast water. USCG Research and Development Center, Groton, CT.

Darrigran, G. (2002): Potential impact of filter-feeding invaders on temperate inland freshwater environments. Biol Invasions 4, pp. 145-156.

Dwight, R.H., Fernandez, L.M., Baker, D.B., Semenza, J.C. and Olson, B.H. (2005): Estimating the economic burden from illnesses associated with recreational coastal water pollution - a case study in Orange County, California. J Env Manag 76, pp. 95-103.

Eng, L. (1979): Population dynamics of the Asiatic clam, Corbicula fluminea (Müller), in the concrete-lined Delta-Mendota Canal of central California, pp. 39-68 in Proceedings, First International Corbicula Symposium. Texas Christian University Research Foundation, Fort Worth, Texas 76129, U.S.A. 
European Commission. (2003): External Costs - Research results on socioenvironmental damages due to electricity and transport. ISBN 92-894-3353-1. http://www.externe.info/externpr.pdf

Fernandez, L. (2007): Maritime trade and migratory species management to protect biodiversity. Env Res Econ 38, pp. 165-188.

Finnoff, D., McIntosh, C., Shogren, J.F., Sims, C. and Warziniack, T. (2010): Invasive species and Endogenous risk. Ann Rev Res Econ 2, pp. 77-100.

Gaffield, S.J., Goo, R.L., Richards, L.A. and Jackson, R.J. (2003): Public health effects of inadequately managed stormwater runoff. Am J Public Health 93, pp. 1527-1533.

Getz, W.M., Haight, R.G. (1989): Population harvesting: Demographic models of fish, forest and animal resources. Princeton University Press.

Hakenkamp, C.C., Ribblett, S.G., Palmer, M.A., Swan, C.M., Reid, J.W. and Goodison, M.R. (2001): The impact of an introduced bivalve (Corbicula fluminea) on the benthos of a sandy stream. Freshwater Biol 46, pp. 491-501.

Hyytiäinen, K., Lehtiniemi, M., Niemi, J.K. and Tikka, K. (2013): An Optimization Framework for Addressing Aquatic Invasive Species. Ecol Econ 91, pp. 69-79.

Ilus, E. (2009): Environmental effects of thermal and radioactive discharges from nuclear power plants in the boreal brackish-water conditions of the northern Baltic Sea. Doctoral dissertation, University of Helsinki, Finnish Radiation and Nuclear Safety Authority STUK-A238.

Jalarvo, E. (2010): Optimization of nuclear power plants outage times. Lappeenranta University of Technology. M.Sc. thesis. $112 \mathrm{p}$.

Kaiser, B.A. and Burnett, K.M. (2010): Spatial economic analysis of early detection and rapid response policies for an invasive species. Res Energy Econ 32, pp. 566-585.

Karatayev, A.Y., Burlakova, L.E., Kesterson, T. and Padilla, D.K. (2003): Dominance of the Asiatic clam, Corbicula fluminea (Muller), in the benthic community of a reservoir. J Shellfish Res 22, pp. 487-493.

Leppäkoski, E., Gollasch, S. and Olenin, S. (2002): Invasive aquatic species of Europedistribution, impacts and management. Kluwer.

Leung, B., Lodge, D.M., Finnof, D., Shogren, J.F., Lewis, M.A. and Lamberti, G. (2002): An ounce of prevention or a pound of cure: bioeconomic risk analysis of invasive species. Proc Royal Soc. B 269, pp. 2407-2413.

Levente, T. and Phaneuf, D.J. (2009): Modeling the human-induced spread of an aquatic invasive: The case of Zebra mussel. Ecological Economics 68, pp. 3060-3071.

McIntosh. C.R., Shogren J.F. and Finnoff, D.C. (2010): Invasive species and delaying the inevitable: valuation evidence from a national survey. Ecological Economics 69, pp. 632-640.

McMahon, R.F. (2002): Evolutionary and physiological adaptations of aquatic invasive animals: selection versus resistance. Canadian Journal of Fisheries and Aquatic Sciences 59, pp. 1235-1244.

Molnar J.L., Gamboa, R.L., Revenga, C. and Spalding, M.D. (2008): Assessing the global threat of invasive species to marine biodiversity. Frontiers in Ecology and the Environment 6, pp. 485-492.

Nunes, P.A.L.D. and van den Bergh, J.C.J.M. (2004): Can people value protection against invasive marine species? Evidence from a joint TC-CV survey in the Netherlands. Environmental \& Resource Economics 28, pp. 517-532.

Occhipinti-Ambrogi A. and Savini D. (2003): Biological invasions as a component of global change in stressed marine ecosystems. Marine Pollution Bulletin 46, pp. 542-551. 
Perry, G.L.W. and Enright, N.J. (2007): Contrasting outcomes of spatially implicit and spatially explicit models of vegetation dynamics in a forest-shrubland mosaic. Ecological Modelling 207, pp. 327-338.

Phillips, S., Darland, T. and Systma, M. (2005): Potential Economic Impacts of Zebra Mussels on the Hydropower Facilities in the Columbia River Basin. Pacific States Marine Fisheries.

Pimentel, D., Zuniga, R. and Morrison, D. (2005): Update on the environmental and economic costs associated with alien-invasive species in the United States. Ecological Economics 52, pp. 273-288.

Port of Kemi. (2012): Maps and routes of Ajos Harbor. http://www.keminsatama.fi/ en/information/maps-and-routes.html (date: 27.1.2012)

Sousa, R.G. (2008): Factors contributing to the invasive success of Corbicula fluminea (Müller, 1774). Doctoral dissertation. Universidade do Porto.

Wright, D.A., Dawson, R.,Cutler, S.J., Cutler, H.G. and Orano-Dawson, C.E. (2007): Screening of Natural Product Biocides for Control of Non-indigenous Species. Env Technol 28, pp. 309-319.

Zaiko, A., Lehtiniemi, M., Narščius, A. and Olenin, S. (2011): Assessment of bioinvasion impacts on a regional scale: a comparative approach. Biological Invasions.

DOI 10.1007/s10530-010-9928-z 



\section{Adaptive harvest strategies in the case of invasive species- induced mortality}

Jon Olaf Olaussen, Trondheim Business School, HiST, Trondheim, Norway

\subsection{Abstract}

This chapter considers adaptive harvest strategies under invasive species-induced mortality. The overall aim is to analyze how the harvest regimes and utility obtained from wild Atlantic salmon change when external factors, such as invasive species-induced mortality, reduce the wild stock survival. The wild salmon stock is associated with both use and non-use values. We have considered two types of adaptive harvest regimes when the salmon is faced with negative consequences from invasive interaction. The first is a selective harvest regime, where the trade-off between the harvest value and the contribution to the recruitment of the stock is taken into account. This harvest regime is contrasted with the traditional uniform harvest pattern across different age classes. We find that the selective type harvest pattern is more important the more important the harvest value is in the social welfare function.

- Keywords: Atlantic salmon, invasive, Artic, age-structured model, social welfare.

- Acknowledgements: I would like to thank Brooks Kaiser and Jarkko K. Niemi for their comments on an earlier draft of this chapter.

\subsection{Introduction}

Man-made activities frequently provide challenges for both terrestrial as well as aquatic species. The most well-known examples are pollution, deforestation, habitat degradation, overfishing and introduction of invasive species. One of the challenges facing management in the Artic is 
invasions. Invasive species may establish in the Artic accidentally due to e.g. ballast water or escapement from aquaculture, intentionally by deliberate introduction or due to habitat alterations associated with climate change. Some changes are hence possible to influence, while others can hardly be influenced. In the same manner, some changes may have huge consequences while in other cases, it may be possible to diminish the consequences to man by adaptation.

In this chapter, we look at the case of wild Atlantic salmon (Salmo salar) harvest under invasive species-induced mortality. Atlantic salmon harvest serves as a good example of a species living within the Artic habitat being vulnerable to invasive species for a number of reasons. As for many Artic species, the potential invader challenges are numerous. Climate change may alter the survival rate in the offshore habitat, inducing introduction of new species competing for the food, or predating directly on the salmon. Salmon farming also increases the wild salmon mortality through increased spawning competition from escapements, destruction of wild salmon spawning nests in the rivers, spread of diseases as well as increased sea lice density.

Atlantic salmon stocks have declined during the last decades. A recent report from the scientific advisory board for salmon management in Norway states that the high sea lice densities, together with escaped farmed salmon from aquaculture, are the two most significant and existential threats to the wild salmon populations in Norway (Anon 2011). Salmon aquaculture increases the sea lice density in the fjords and along the coast because it amplifies the number of hosts for the lice by a magnitude of 100 (Heuch et al. 2005). Aquacultured salmon is considered an invasive itself since it is genetically different from any of the wild salmon stocks due to the special breeding program for farmed salmon.

In this chapter we apply an age-structured wild salmon population model to assess the welfare loss of the invasive species-induced mortality. The economic losses and effects on the fishing mortalities are analyzed by obtaining the reduced harvesting value of the mature salmon due to various invasive induced mortality scenarios. ${ }^{2}$ First, we analyze what happens when the wild salmon manager aims to maximize the social sustainable value of the wild stock consisting of harvest plus stock value under selective harvesting of the different age classes. Then, in a next step, we analyze the situation in which a uniform fishing mortality rate is applied across the different age classes.

${ }^{2}$ In the fisheries literature, fishing mortalities refer to harvest rates. 
The reason for analyzing these different harvest strategies is that, during the last decade, the management regime of the wild Atlantic salmon in Norway has gradually shifted from one in which a fish is considered "just a fish" towards one with a selective harvesting pattern for each year class of mature salmon (Thorstad et al. 2001). This is made possible by allowing for catch and release management; that is, a regime in which the angler can release the salmon if the bag limit for that specific year class of salmon (measured by size) is met. This has also made it possible to allow angling for, e.g., the smallest type of mature salmon; that is, salmon less than $3 \mathrm{~kg}$, or the so called 1SW, while all older (bigger) salmon must be released. ${ }^{3}$ This new potential flexibility in management has however not yet been put fully into effect, and the difference in management practice among rivers is large. This may possibly hinge on the lack of analysis of what the best harvest regime would look like under different mortality levels. The overall aim of this chapter is hence to assess the welfare loss of increased mortality under different scenarios, and to explore to what extent the optimal adaptive harvesting policy is affected by invasive-induced mortality.

Both fishery ecologists (e.g., Hilborn and Walters 2001; Walters and Martell 2004) and economists (e.g., Wilen 1985; Townsend 1986) have argued that management models should be based on age- and/or -stagestructured biological models instead of the simplified biomass models. Due to the complexity of age structured models, economic studies based on such models have basically been case studies illustrated by numerical analysis. One noteworthy exception is Tahvonen (2009), who demonstrates analytical results on optimal harvesting under certain simplifying assumptions within a dynamic framework. In addition, Skonhoft et al. (2012) analyzed a static maximum economic yield fishery with three age classes under perfect and imperfect selectivity, and demonstrated several analytical results that contrast what are found in the biomass models. In closer relation to the present study, Massey et al. (2006) developed a stage-structured bioeconomic model of the recreational Atlantic coast summer flounder fishery. They look at the benefits of improving the water quality conditions in Maryland's coastal bays. When the benefits are compared with estimates from a non-structural model, they find that the unstructured model is likely to lead to inaccurate predictions.

\footnotetext{
3 1SW are salmon that have stayed 1 winter (e.g. 1 sea winter) in the offshore habitat before they return to spawn in the river. Further, 2SW and 3SW have stayed 2 and 3 winters, respectively, before spawning migration.
} 
This study is structured as follows. The next section presents the population model and welfare function associated with the wild salmon. Then, a numerical illustration applying Norwegian salmon data is presented. Some concluding remarks and management implications are given in the final section.

\subsection{Population model and welfare function}

\subsubsection{Atlantic salmon}

Atlantic salmon is an anadromous species with a complex life cycle that includes several distinct phases. Freshwater habitat is essential for the early development stages, where it spends the first 1-4 years from spawning to juvenile rearing, before undergoing smoltification and seaward migration. It then stays from 1-3 years feeding and growing in the ocean, and, when mature, it returns to its natal, or "parent", rivers to spawn in the spring and/or summer. A fraction of the stock returns to spawn after only one winter in the offshore habitat. This is the 1SW (Sea winter) sub-population that is typically $1-3 \mathrm{~kg}$. Another fraction returns after two winters, the 2SW sub-population that is typically between 3-7 $\mathrm{kg}$. The remaining part of the stock returns after three winters, the 3SW sub-population that is typically above $7 \mathrm{~kg}$. After spawning in autumn, most salmon die, as less than $10 \%$ of the female salmon spawn twice (Mills 2000). The Atlantic salmon is subject to fishing when it migrates back to its parent river. In Norway, sea fishing takes place in fjords and inlets with wedge-shaped seine and bend nets, and is commercial or semi-commercial. In the rivers, salmon are caught by recreational anglers with fishing rods. The recreational fishery is the far most important from an economic point of view (NOU 1999), but in number and biomass of fish caught, these two fisheries are today more or less equivalent (Anon. 2011; Liu et al. 2011). More than half of the present commercial catch is caught in the Finnmark County, while in the remaining 18 counties, the commercial harvest is already shut down or rapidly decreasing due to strict regulations (Statistics Norway 2011). In the following, we assume all harvest takes place in the rivers. There are two main reasons for this. First, due to strict regulations of the marine salmon fishery since 2008 , sea fishing seems to gradually be fading away, and is already nonexistent in many fjords (Statistics Norway 2011). Second, we want to look at the most valuable harvest pattern, and it is well known that this involves zero marine harvest (see e.g. Olaussen 2007; Liu et al. 2011). 


\subsubsection{Welfare}

Atlantic salmon may be valued both for use as well as non-use values. In the following, we consider the recreational harvest value (use value) and the intrinsic stock value (non-use value). The utility from recreational harvest of salmon is given by the utility function $U\left(Y_{t}\right)$. In general, the utility from harvest is a measure of the value of the catches, accounting for differences in the weights, values, and catchability of the different year classes of salmon. Readers that are not particularly interested in the specific model details may now move to the numerical illustration section. In the utility function, $Y_{t}$ is the year class scaled biomass harvested (in $\mathrm{kg}$ ) in year $t$. With $w_{3}, w_{2}$, and $w_{1}$ as the fixed weights (kg per fish, with $w_{3}>w_{2}>w_{1}$ ) and $f_{3}, f_{2}$, and $f_{1}$ as the harvest fractions of the $3 \mathrm{SW}, 2 \mathrm{SW}$, and $1 \mathrm{SW}$ mature population, respectively, the biomass harvested (in $\mathrm{kg}$ ) in year $t$ is defined by

$y_{t}=w_{1} s_{1} \sigma f_{1, t} N_{0, t}+w_{2} s_{1}(1-\sigma) \varphi s_{2} f_{2, t} N_{0, t-1}+w_{3} s_{1}(1-\sigma-\varphi+\varphi \sigma) s_{2} s_{3} f_{3, t} N_{0, t-2}$

Here, the fraction of the stock that returns after one winter at sea is $\sigma$, and hence $(1-\sigma) \varphi$ is the fraction that returns after two winters at sea and $(1-\sigma-\varphi+\varphi \sigma)$ is the fraction that returns after three sea winters. Finally, $N_{0}$ is the number of recruits that make it to the offshore habitat, and $s_{1}, s_{2}$ and $s_{3}$ are the stage-specific survival rates respectively. The utility obtained from different year classes may typically differ. For example, recreational anglers may prefer harvest of 3SW salmon over 2SW salmon and 2SW over 1SW. This could be due to the trophy aspect of the fishing experience (see Nævdal et al. 2012). To allow for different valuation of different age classes, we have the scaling parameter $z_{i}(i=1,2,3)$ for each of the year classes in the harvest, and hence the year class scaled biomass harvested is written

$Y_{t}=z_{1} w_{1} s_{1} \sigma f_{1, t} N_{0, t}+z_{2} w_{2} s_{1}(1-\sigma) \varphi s_{2} f_{2, t} N_{0, t-1}+z_{3} w_{3} s_{1}(1-\sigma-\varphi+\varphi \sigma) s_{2} s_{3} f_{3, t} N_{0, t-2}$

Note that since the scaling parameters for the different year classes, $z_{i}$, are determined by the preferences for salmon in the recreational fishery, we typically have $z_{3} \geq z_{2} \geq z_{1}$ (Olaussen and Liu 2011).

The non-harvest related utility obtained from the stock is given by the utility function $V\left(Q_{t}\right)$ where

$Q_{t}=w_{1} s_{1} \sigma\left(1-f_{1, t}\right) N_{0, t}+w_{2} s_{1}(1-\sigma) \varphi s_{2}\left(1-f_{2, t}\right) N_{0, t-1}+w_{3} s_{1}(1-\sigma-\varphi+\varphi \sigma) s_{2} s_{3}\left(1-f_{3, t}\right) N_{0, t-2}$ represent the stock (in $\mathrm{kg}$ ) after harvest has taken place. Both $V\left(Q_{t}\right)$ and $U\left(Y_{t}\right)$ are assumed to be increasing and concave functions, that is, a higher salmon stock as well as a higher harvest yields a higher utility, but at a declining rate. 
We next formulate a welfare, or utility, function that takes both the conservation and the use perspective of salmon into account (see Liu et al. 2013). The utility provided through harvesting salmon (use value) and the utility derived from the intrinsic value (non-use-value) the wild salmon stock possesses are both included in the social welfare function $W_{t}=W\left[U\left(Y_{t}\right), V\left(Q_{t}\right)\right]$. When assuming separability, the social welfare at time t can be written $W_{t}=\alpha\left[U\left(Y_{t}\right)\right]+(1-\alpha)\left[V\left(Q_{t}\right)\right]$.

The parameter $0 \leq \alpha \leq 1$ is a weighting factor between use and nonuse values. Hence, if $\alpha=1$, only harvest counts in the welfare function, while $\alpha=0$ implies that only the intrinsic value is taken into account. Consequently, $\alpha=0.5$ indicates an equal valuation of harvest and stock abundance.

\subsection{A Numerical illustration}

The specific biological and economic model is quite complex. ${ }^{4}$ For the specific purpose of this chapter, it is sufficient to acknowledge that the model is solved by maximizing the social welfare in equilibrium, that is, a situation in which no one has incentive to change their behavior. Further, the Kuhn-Tucker first order conditions that define the optimization provide easily interpreted equations. It turns out that for the Norwegian data, straightforward harvest patterns are revealed as long as we assume that the recreational anglers are indifferent with respect to which year class they harvest. In this case, only the biomass/fecundity ratio $w_{i} / \gamma_{i}(i=1,2,3)$ steer the fishing mortality and the fishing composition, and hence no other factors play a direct role. Here $w_{i}$ is the average weight of the year class $i$ while $\gamma_{i}$ is the average fecundity of the same year class. The intuition behind these relative ratios is that they determine the relative economic (through the weights, $w_{i}$ ) versus the biological (through the fecundities, $\gamma_{i}$ ) of the different year classes. For the wild Atlantic salmon, the data give us the following relationship: $w_{1} / \gamma_{1}>w_{3} / \gamma_{3}>w_{2} / \gamma_{2}$, which determines the optimal harvest pattern. By harvest pattern, we mean year classes that are harvested, and to what extent. Generally, the Kuhn-Tucker first order conditions give us thirty different potential harvest patterns. For example, when we have

${ }^{4}$ Both the model specification and parameter values are available on authors request. 
$w_{1} / \gamma_{1}>w_{3} / \gamma_{3}>w_{2} / \gamma_{2}$, which is in accordance with our Norwegian wild salmon data, there will be five potential harvest patterns given by i) $f_{1}=1, f_{3}=1,0<f_{2}<1$, ii) $f_{1}=1, f_{3}=1, f_{2}=0$, iii) $f_{1}=1, \quad 0<f_{3}<1, f_{2}=0$, iv) $f_{1}=1, f_{3}=0, f_{2}=0$, v) $0<f_{1}<1, f_{3}=0, f_{2}=0.5$

Clearly, the most aggressive harvest pattern is given by case i), where the whole 1SW and 3SW sub populations are harvested. Then, harvest pattern ii) is less aggressive, and so on, with harvest pattern v) giving the lowest harvesting pressure; that is, only harvesting some proportion of the 1 SW.

\subsubsection{Results}

Managing for harvest value only, $\alpha=1$

First, we look at the harvest pattern when the manager is concerned with the use value only (harvest value).With weight-fertility variations as $w_{1} / \gamma_{1}>w_{3} / \gamma_{3}>w_{2} / \gamma_{2}$, we find that the potential optimal fishing mortality possibilities under the assumption of perfect fishing selectivity are given by cases i) - v) as described above. In the baseline scenario, we find that case i) with $f_{1}=f_{3}=1$ and $f_{2}=0.52$ yields the optimal fishing mortality pattern. See Table 1 (first column). Based on valuation data from a typical small Norwegian salmon river, the overall social welfare becomes 3.808 (NOK 100,000), consisting of utility obtained from harvest only (Olaussen 2007, Olaussen and Liu 2011). The consequences of invasive species-induced mortality are also demonstrated in Table 1 . It is not possible to give an accurate estimate regarding how much the smolt survival, $s$, is reduced due to invasive induced mortality on a national scale. Note that the smolt mortality takes place before the smolt reaches the offshore winter habitat, and should not be confused with the stage specific mortalities. Hence, the $N_{0}$ population from above is the population remaining after the smolt stage. The mortality effect due to invasives varies between fjords, and from river to river. To take this variation into account, we assess the consequences at different mortality levels. When the smolt mortality increases such that the survival rate $s$ decreases, the fishing mortality for $2 \mathrm{SW}$ decreases while it is still opti-

\footnotetext{
${ }^{5}$ The twenty-five remaining possibilities are found by assuming $w_{1} / \gamma_{1}>w_{2} / \gamma_{2}>w_{3} / \gamma_{3}$ $w_{2} / \gamma_{2}>w_{3} / \gamma_{3}>w_{1} / \gamma_{1}, w_{2} / \gamma_{2}>w_{1} / \gamma_{1}>w_{3} / \gamma_{3}$, $w_{3} / \gamma_{3}>w_{2} / \gamma_{2}>w_{1} / \gamma_{1}$, and $w_{3} / \gamma_{3}>w_{1} / \gamma_{1}>w_{2} / \gamma_{2}$.
} 
mal to keep $f_{1}=f_{3}=1$ at the $40 \%$ smolt survival reduction ( $\mathrm{s}=0.03$ ), and we hence have pattern i) as described above. With this survival rate, the utility is reduced by about $17 \%$ to 3.175 (NOK 100,000). The same harvest pattern is kept even for a $60 \%$ reduction in the smolt survival ( $s=0.02$ ). In this case, the utility is reduced significantly and is now only 1718 (NOK 1,000), that is, about one third of the profit in the baseline scenario. With an $80 \%$ reduction in the baseline smolt survival rate and $s=0.01$, we find that it is still optimal to harvest the whole 1SW stage population, while the harvest of the $3 \mathrm{SW}$ is reduced to $f_{3}=0.98$, and there is no harvest of 2SW fish. We then have the above described pattern iii). The same case is still present when the smolt survival is further reduced to $s=0.005$. Note that the $N_{0}$ harvestable population decreases relatively more than the social welfare for all reductions in the survival parameter since the marginal utility is decreasing in number of fish (concave social welfare function). As a result, the utility is reduced less; that is, the social welfare is reduced by about $42 \%$ (1618) when the survival rate is reduced by $80 \%(s=0.01)$.

It may seem surprising that even when the smolt survival is reduced by $90 \%$, the harvest is still quite aggressive. The reason is that the recruitment function is very steep at low stock levels. However, it may be shown that the shape of the recruitment function must be altered quite significantly before the second most aggressive harvest pattern (pattern ii)) replaces the most aggressive (pattern i)).

Table 1: Managing for harvest value only $(\alpha=1)$. Optimal fishing mortalities under different invasive-induced mortality levels

\begin{tabular}{lrrrrrrrrrr} 
& $f_{1}$ & $f_{2}$ & $f_{3}$ & $N_{0}$ & $H_{1}$ & $H_{2}$ & $H_{3}$ & $U$ & $V$ & $W$ \\
$\mathrm{~s}=0.05$ & 1 & 0.52 & 1 & 1663 & 358 & 68 & 53 & 3.808 & 1.884 & 3.808 \\
$\mathrm{~s}=0.04$ & 1 & 0.46 & 1 & 1299 & 279 & 47 & 42 & 3.535 & 1.755 & 3.535 \\
$\mathrm{~s}=0.03$ & 1 & 0.38 & 1 & 933 & 202 & 28 & 30 & 3.175 & 1.568 & 3.175 \\
$\mathrm{~s}=0.02$ & 1 & 0.24 & 1 & 587 & 126 & 11 & 19 & 2.641 & 1.301 & 2.641 \\
$\mathrm{~s}=0.01$ & 1 & 0 & 0.98 & 240 & 51 & 0 & 8 & 1.618 & 0.698 & 1.618 \\
$\mathrm{~s}=0.005$ & 1 & 0 & 0.30 & 90 & 19 & 0 & 1 & 0.282 & 0.088 & 0.282 \\
\hline
\end{tabular}

Note: $s$ is the lumped survival rate from the juvenile to the smolt stage where $s=0.05$ is the survival rate in absence of sea lice. $f_{1}, f_{2}$ and $f_{3}$ are harvest rates for the $1 \mathrm{SW}, 2 \mathrm{SW}$ and 3SW class,

respectively. $N_{0}$ is the potentially harvestable population. $H_{1}, H_{2}$, and $H_{3}$ are the harvest (in number of salmon) of the $1 \mathrm{SW}, 2 \mathrm{SW}$, and $3 \mathrm{SW}$, respectively, while $U$ is the utility in the recreational fishery, $V$ is the non-consumptive utility and $W$ is the weighted social welfare $(U, V$ and $W$ all measured in NOK 100,000). NOK 1 = USD 0.17 (Aug. 21 2013). 
Managing for harvest and stock value, $\alpha=0.5$

As expected, when the manager takes both harvest and the stock value (non-consumptive value) into account, the optimal harvest pattern is less aggressive. In the baseline case, we have the harvest pattern iii) from above with $f_{1}=1, f_{3}=0.31$, and $f_{2}=0$. If natural mortality is reduced by $80 \%$ ( $\mathrm{s}=0.01$ ), we have harvest pattern iv) with $f_{1}=1, f_{3}=0$, and $f_{2}=0$. Finally, a further reduction of the natural mortality, $s=0.005$, gives the harvest pattern $\mathrm{v}$ ) from above with $f_{1}<1, f_{3}=0$, and $f_{2}=0$. Not surprisingly, when use and non-use values are weighted equally, the stock will be higher, while the harvest, and hence the harvest value, will be lower.

Table 2: Managing for harvest and non-consumptive values ( $\alpha=0.5$ ). Optimal fishing mortalities under different invasive-induced mortality levels

\begin{tabular}{lllllllllll} 
& $f_{1}$ & $f_{2}$ & $f_{3}$ & $N_{0}$ & $H_{1}$ & $H_{2}$ & $H_{3}$ & $U$ & $V$ & $W$ \\
$\mathrm{~s}=0.05$ & 1 & 0 & 0.31 & 1886 & 405 & 0 & 19 & 3.372 & 3.148 & 3.260 \\
$\mathrm{~s}=0.04$ & 1 & 0 & 0.29 & 1287 & 320 & 0 & 14 & 3.124 & 2.920 & 3.022 \\
$\mathrm{~s}=0.03$ & 1 & 0 & 0.25 & 1089 & 234 & 0 & 9 & 2.791 & 2.627 & 2.709 \\
$\mathrm{~s}=0.02$ & 1 & 0 & 0.17 & 692 & 149 & 0 & 4 & 2.292 & 2.211 & 2.252 \\
$\mathrm{~s}=0.01$ & 1 & 0 & 0 & 299 & 64 & 0 & 0 & 1.350 & 1.445 & 1.398 \\
$\mathrm{~s}=0.005$ & 0.94 & 0 & 0 & 100 & 20 & 0 & 0 & 0.195 & 0.391 & 0.293 \\
\hline
\end{tabular}

Note: $s$ is the lumped survival rate from the juvenile to the smolt stage where $s=0.05$ is the survival rate in absence of sea lice. $f_{1}, f_{2}$ and $f_{3}$ are harvest rates for the $1 \mathrm{SW}, 2 \mathrm{SW}$ and $3 \mathrm{SW}$ class,

respectively. $N_{0}$ is the potentially harvestable population. $H_{1}, H_{2}$, and $H_{3}$ are the harvest (in number of salmon) of the $1 \mathrm{SW}, 2 \mathrm{SW}$, and $3 \mathrm{SW}$, respectively, while $U$ is the utility in the recreational fishery, $V$ is the non-consumptive utility and $W$ is the weighted social welfare $(U, V$ and $W$ all measured in NOK 100,000). NOK 1 = USD 0.17 (Aug. 21 2013)

Managing for stock value only, $\alpha=0$

When the manager only takes the stock value of the salmon into consideration, no harvest takes place. Consequently, this is the case where the invasive species-induced mortality has least impact on the stock level. Furthermore, since social welfare is dependent on the stock value only, this is the case where the social welfare reduction is smallest. In this case, due to the concave utility function, an $80 \%$ reduction in the survival rate reduces the stock level by $83 \%$, while the social welfare is reduced by less than $50 \%$. 
Table 3: Managing for non-consumptive values only ( $\alpha=0)$. Optimal fishing mortalities under different invasive-induced mortality levels

\begin{tabular}{lrrrrrrrrrrr} 
& $f_{1}$ & $f_{2}$ & $f_{3}$ & $N_{0}$ & $H_{1}$ & $H_{2}$ & $H_{3}$ & $U$ & $V$ & $W$ \\
$\mathrm{~s}=0.05$ & 0 & 0 & 0 & 1917 & 0 & 0 & 0 & 0 & 3.808 & 3.808 \\
$\mathrm{~s}=0.04$ & 0 & 0 & 0 & 1518 & 0 & 0 & 0 & 0 & 3.574 & 3.574 \\
$\mathrm{~s}=0.03$ & 0 & 0 & 0 & 1117 & 0 & 0 & 0 & 0 & 3.268 & 3.268 \\
$\mathrm{~s}=0.02$ & 0 & 0 & 0 & 717 & 0 & 0 & 0 & 0 & 2.824 & 2.824 \\
$\mathrm{~s}=0.01$ & 0 & 0 & 0 & 318 & 0 & 0 & 0 & 0 & 2.008 & 2.008 \\
$\mathrm{~s}=0.005$ & 0 & 0 & 0 & 117 & 0 & 0 & 0 & 0 & 1.012 & 1.012 \\
\hline
\end{tabular}

Note: $s$ is the lumped survival rate from the juvenile to the smolt stage where $s=0.05$ is the survival rate in absence of sea lice. $f_{1}, f_{2}$ and $f_{3}$ are harvest rates for the $1 \mathrm{SW}, 2 \mathrm{SW}$ and $3 \mathrm{SW}$ class, respectively. $N_{0}$ is the potentially harvestable population. $H_{1}, H_{2}$, and $H_{3}$ are the harvest (in number of

salmon) of the $1 \mathrm{SW}, 2 \mathrm{SW}$, and $3 \mathrm{SW}$, respectively, while $U$ is the utility in the recreational fishery, $V$ is the non-consumptive utility and $W$ is the weighted social welfare $(U, V$ and $W$ all measured in NOK 100,000). NOK 1 = USD 0.17 (Aug. 21 2013)

\section{Managing for harvest value only, $\alpha=1$, optimal uniform harvest rate} Now we turn our attention to the case where the manager does not separate between different age classes, and hence, a uniform harvest rate is applied. As in the cases considered above, the optimal harvest rate is quite high, even for a quite dramatic reduction in the survival rate. For example, a $90 \%$ reduction in the survival rate reduces the optimal uniform harvest rate only from 0.80 to 0.36 . The social welfare, however, is reduced much more under the uniform harvest rate than in the stagespecific harvest case ( 0.019 vs. 0.282 ). Note also that in the baseline case $(\mathrm{s}=0.05)$ without invasive species-induced mortality, the social welfare under the uniform harvest rate is only slightly below (2\%) the stagestructured harvest pattern.

Table 4: Managing for harvest value only $(\alpha=1)$. Optimal uniform fishing mortality under different invasive-induced mortality levels

\begin{tabular}{lrrrrrrrrrr} 
& $f_{1}$ & $f_{2}$ & $f_{3}$ & $N_{0}$ & $H_{1}$ & $H_{2}$ & $H_{3}$ & $U$ & $V$ & $W$ \\
s=0.05 & 0.80 & 0.80 & 0.80 & 1593 & 273 & 99 & 41 & 3.721 & 2.033 & 3.721 \\
$\mathrm{~s}=0.04$ & 0.77 & 0.77 & 0.77 & 1236 & 205 & 75 & 31 & 3.436 & 1.890 & 3.436 \\
$\mathrm{~s}=0.03$ & 0.74 & 0.74 & 0.74 & 884 & 140 & 51 & 21 & 3.055 & 1.699 & 3.055 \\
$\mathrm{~s}=0.02$ & 0.68 & 0.68 & 0.68 & 542 & 79 & 29 & 12 & 2.481 & 1.412 & 2.481 \\
$\mathrm{~s}=0.01$ & 0.54 & 0.54 & 0.54 & 218 & 26 & 9 & 4 & 1.352 & 0.845 & 1.352 \\
$\mathrm{~s}=0.005$ & 0.36 & 0.36 & 0.36 & 71 & 5 & 2 & 1 & 0.019 & 0.074 & 0.019 \\
\hline
\end{tabular}

Note: $s$ is the lumped survival rate from the juvenile to the smolt stage where $s=0.05$ is the survival rate in absence of sea lice. $f_{1}, f_{2}$ and $f_{3}$ are harvest rates for the $1 \mathrm{SW}, 2 \mathrm{SW}$ and $3 \mathrm{SW}$ class, respectively. $N_{0}$ is the potentially harvestable population. $H_{1}, H_{2}$, and $H_{3}$ are the harvest (in number of salmon) of the $1 S W$, $2 S W$, and $3 S W$, respectively, while $U$ is the utility in the recreational fishery, $V$ is the non-consumptive utility and $W$ is the weighted social welfare $(U, V$ and $W$ all measured in NOK 100,000). NOK $1=$ USD 0.17 (Aug. 21 2013). 
Managing for harvest and stock value, $\alpha=0.5$, uniform harvest rate A $90 \%$ reduction in the survival rate has a relatively modest effect on the uniform harvest rate that is reduced from 0.46 to 0.23 . In the case when only the harvest value mattered considered above, the social welfare effect of a uniform harvest rate was quite modest in the baseline case with survival rate $s=0.05$, and quite substantial when the survival rate was only 0.005 . When the stock value matters in the social welfare function, the welfare difference between the uniform and stage-specific harvest rate is much less dramatic. The intuition is straightforward as the more important harvest is in the welfare function, the more impact will a more sophisticated (stage-structured) harvest pattern have compared with a simple uniform harvest pattern.

When it comes to adaptive harvest, both the stage-structured and uniform harvest patterns must be considered adaptive because the harvest rate is changed due to invasive species-induced mortality. In absence of adaptive capacity in the management, that is, if the uniform harvest rate is kept fixed under all invasive species-induced mortality levels, the stock would go extinct.

Table 5: Managing for harvest and non-consumptive values ( $\alpha=0.5$ ). Optimal uniform fishing mortality under different invasive-induced mortality levels

\begin{tabular}{lrrrrrrrrrr} 
& $f_{1}$ & \multicolumn{1}{c}{$f_{2}$} & $f_{3}$ & $N_{0}$ & $H_{1}$ & $H_{2}$ & $H_{3}$ & $U$ & $V$ & $W$ \\
$\mathrm{~s}=0.05$ & 0.46 & 0.46 & 0.46 & 1846 & 183 & 67 & 27 & 3.322 & 3.152 & 3.237 \\
$\mathrm{~s}=0.04$ & 0.45 & 0.45 & 0.45 & 1448 & 141 & 51 & 21 & 3.062 & 2.924 & 2.993 \\
$\mathrm{~s}=0.03$ & 0.44 & 0.44 & 0.74 & 1052 & 99 & 36 & 15 & 2.711 & 2.630 & 2.670 \\
$\mathrm{~s}=0.02$ & 0.41 & 0.41 & 0.41 & 659 & 58 & 21 & 9 & 2.179 & 2.209 & 2.194 \\
$\mathrm{~s}=0.01$ & 0.34 & 0.34 & 0.34 & 274 & 20 & 7 & 3 & 1.115 & 1.443 & 1.279 \\
$\mathrm{~s}=0.005$ & 0.23 & 0.23 & 0.23 & 92 & 4 & 2 & 1 & 0.004 & 0.512 & 0.258 \\
\hline
\end{tabular}

Note: $s$ is the lumped survival rate from the juvenile to the smolt stage where $s=0.05$ is the survival rate in absence of sea lice. $f_{1}, f_{2}$ and $f_{3}$ are harvest rates for the 1SW, 2SW and 3SW class, respectively. $N_{0}$ is the potentially harvestable population. $H_{1}, H_{2}$, and $H_{3}$ are the harvest (in number of salmon) of the $1 \mathrm{SW}, 2 \mathrm{SW}$, and $3 \mathrm{SW}$, respectively, while $U$ is the utility in the recreational fishery, $V$ is the non-consumptive utility and $W$ is the weighted social welfare $(U, V$ and $W$ all measured in NOK 100,000). NOK 1 = USD 0.17 (Aug. 21 2013). 


\subsection{Concluding remarks}

In this paper, we have analyzed one example of the more general class of problems where invasive species provide challenges for native species. The overall aim of this example has been to analyze how the harvest regimes and profitability of wild Atlantic salmon may be changed when external factors, such as invasive species-induced mortality, reduces the natural smolt survival rate. The wild salmon stock is associated with both use and non-use values. We have considered two types of adaptive harvest regimes when the salmon is faced with negative consequences from invasive interaction. The first is a selective harvest regime, where the trade-off between the harvest value and the contribution to the recruitment of the stock is taken into account. This harvest regime is contrasted with the traditional uniform harvest pattern across different age classes. Not allowing different harvest rates for different stages of the salmon stock turns out to reduce the welfare considerably, and seems to be more important the higher the invasive species-induced mortality is. We find that the selective harvest pattern is more important the more important the harvest value is in the social welfare function.

We have found that increased invasive species-induced mortality does not necessarily call for altered harvest regimes, particularly when the mortality reduction was not too strong. In fact, we found surprisingly aggressive harvest patterns to be persistent even under quite high invasive species-induced mortality situations. However, if a fixed uniform fishing mortality is applied, high invasive species-induced mortality may drive the population to extinction. Thus, an optimal selective harvesting regime should be employed to secure both the highest potential welfare and a viable population.

\subsection{References}

Anon. 2011. Status for norske laksebestander i 2011. Rapport fra Vitenskapelig råd for lakseforvaltning nr 3, pp. 285.

Heuch, P.A., Bjørn, P.A., Finstad, B., Holst, J.C., Asplin, L., and Nilsen, F. 2005. A review of the Norwegian National Action Plan against Salmon Lice on Salmonids: The effect on wild salmonids. Aquaculture 246: pp. 79-92.

Hilborn, R., and Walters, C.J. 2001. Quantitative Fisheries Stock Assessment: Choice Dynamics and Uncertainty. London: Chapman \& Hall.

Liu, Y., Diserud, O., Hindar, K. and Skonhoft, A. 2013. An ecological - economic model on the effects of interactions between escaped and farmed salmon (Salma salar).

Fish and Fisheries 14(2): pp. 158-173. 
Liu, Y., Olaussen, J.O, and Skonhoft, A. 2011. Wild and farmed salmon in Norway: A review. Marine Policy, 35: 413-418.

Massey, D.M., Newbold, S.C., and Gentner, B. 2006. Valuing water quality changes using a bioeconomic model of a coastal recreational fishery. Journal of Environmental Economics and Management 52 (2006): 482-500.

Mills, D. 2000. The Ocean Life of Atlantic Salmon: Environmental and Biological Factors Influencing Survival. New York: Chapman and Hall.

NOU 1999. Til Laks åt Alle Kan Ingen Gjera? NOU 1999: 9.

Nævdal, E., Olaussen, J.O., and A. Skonhoft (2012): A bioeconomic model of trophy hunting. Ecological Economics 73(1): 194-205

Olaussen, J.0. 2007. Playing chicken with salmon. Marine Resource Economics 22 (2): 173-193.

Olaussen, J.O. and Liu, Y., 2011. On the willingness-to-pay for recreational fishing: Escaped farmed versus wild Atlantic salmon. Aquaculture Economics \& Management 15(4): 245-261

Skonhoft, A., Vestergård, N., and Quaas, M., 2012. Optimal harvesting in an age structured model with different fishing selectivity. Environmental and Resource Economics, 525-554.

Statistics Norway 2011. Focus on hunting and angling. http://www.ssb.no/english/ subjects/10/04/10/jakt_fiske_en/

Tahvonen, O. 2009. Economics of harvesting age-structured fish populations. Journal of Environmental Economics and Management 58, 281-299.

Thorstad, E.B., Næsje, T.F., Fiske, P., Leinan, I., Leinan, T. and Berger, H.M., 2001.

Effects of catch and release fishing: studies of radio tagged Atlantic salmon in River Alta in 1999 and 2000. NINA oppdragsmelding 713, 1-19

Townsend, R.E. 1986. A critique of models of the American lobster fishery. Journal of Environmental Economics and Management 13, 277-291.

Walters, C.J., and Martell, S.J.D. 2004. Fisheries Ecology and Management. Princeton: Princeton University Press.

Wilen, J.E. 1985. Bioeconomics of renewable resource use. In: A.V. Kneese, J.L. Sweeney (Eds.), Handbook of Natural Resource and Energy Economics, vol. 1. Amsterdam: Elsevier. 

Section 5:

Invasive Species Management and Policy 



\section{The interaction of natural and social systems: how International Relations theory can inform research on Arctic marine invasive species}

Rasmus Gjedssø Bertelsen, Aalborg University, Aalborg, Denmark.

\subsection{Introduction: Natural and social systems, International Relations theory and invasive species in the Arctic}

Marine invasive species are an excellent case of the interlinking of natural and social systems, as they display feedback between these systems. This essay will discuss how International Relations theory can outline research agendas and supply useful concepts and assumptions of actors and causalities for exploring this interlinking.

Search on International Relations literature and invasive species yield little (Bright 1999). It is therefore a research field to be developed. It is clear from this workshop and this volume that the question of marine invasive species in the Arctic are a case of how international political and economic processes are affecting and could affect biological systems with feedback to politics and the economy. It therefore seems appropriate to outline how Arctic marine invasive species can be explored in International Relations.

This chapter will discuss possible International Relations research agendas on Arctic marine invasive species through the following steps. In light of the absence of such a tradition and to introduce such a possible tradition outside circles of political scientists, International Relations research in the Arctic and International Relations theory will be introduced as a starting point. 
Initially International Relations reseach topics on the Arctic will be briefly introduced. Then the scholarly and policy importance of linking natural and social systems, such as concerning Arctic marine invasive species, will be discussed briefly. These discussions lead to the main part of the chapter, which is a discussion of how the main theoretical traditions in International Relations, realism, liberalism, institutionalism, transnationalism, and constructivism each can propose research agendas with concepts and assumptions of actors and causalities for analyzing the international politics dimensions of Arctic marine invasive species. Finally, there is a brief concluding discussion of how International Relations theory can contribute to the debate and analysis of the interlinking of natural and social systems in general and in particular concerning Arctic marine invasive species.

\subsection{Doing International Relations Arctic research}

The Arctic is a science-dense region compared to other human activity in the region, and much popular and media attention to the region has been because of science and exploration. ${ }^{6}$ The region is very big with important natural science phenomena, while relatively few people live there. The research attention to the Arctic has therefore historically predominantly been natural scientific. This predominance has been reflected in the international organization of Arctic research such as the previous International Polar Years and international scientific organizations. In recent years, the human and social sciences aspects of Arctic research have gained attention and strength as reflected in the most recent International Polar Year (they have naturally always been there, especially with ethnographic research on the indigenous peoples of the North) (Barr, Luedecke 2010; Launius, Fleming, DeVorkin 2010).

The field of International Relations interacts with its subject matter, international politics, also concerning the Arctic. International Relations are also a fairly young discipline, which emerged in the interwar years from the carnage of World War One. The Arctic came into international politics with the Cold War. In this conflict, the Arctic was a theatre of confrontation between the superpowers and of deployment of strategic

\footnotetext{
${ }^{6}$ See, for instance, the Arktis exhibition at Louisiana, 26.9.2013-2.2.2014,

http://www.louisiana.dk/dk/Menu/Udstillinger/Tidligere+udstillinger/ARKTIS/Arktis
} 
nuclear weapon systems and warning systems. Arctic International Relations research reflected this (Heininen, Southcott 2010).

With the thaw between East and West under Mikhail Gorbachev, Arctic international politics changed as well. In 1987, Gorbachev gave the famous Murmansk speech calling for Arctic environmental and research collaboration and disarmament. Finland followed up on this opening with the Rovaniemi process leading to the Arctic Environmental Protection Strategy in 1991. Canada continued this momentum leading to the Ottawa declaration of 1996 establishing the Arctic Council. These developments made the Arctic an area of transnational environmental and research collaboration between the Arctic states and some European states with Arctic research traditions (Heininen, Southcott 2010).

Readers are undoubtedly aware of the expanded global interest in the Arctic in recent years, which culminated in the admission of rising or established Asian powers, China, India, Japan, South Korea and Singapore, as permanent observers to the Arctic Council in May 2013. This Asian interest in the Arctic is driven by environmental (climate change) and politicaleconomic globalization. For instance, Arctic climate change may affect its Chinese weather patterns and thus agriculture and food security with possible impacts on social and political stability. The "rise of the rest" (especially Asia) in the world economy shifts economic and eventually political power to the East. Countries as China and India see themselves as natural stakeholders in the governance of regions around the world, including the Arctic. The rise of Asia has led to an almost insatiable appetite for raw materials and energy, where the Arctic is a possible new politically stable supplier region. The Asian growth economies are export-based economies, whose exports travel on ships, and new, shorter and securer shipping lanes to markets in Western Europe and the East Coast of North America are therefore of interest. Arctic International Relations scholarship today is to a significant extent about this global attention to the region (Li, Bertelsen 2013, also for literature review).

More concrete examples of Arctic International Relations scholarship with relevance for Arctic marine invasive species looks at the history, present and future of the North Atlantic parts of the Kingdom of Denmark (Iceland previously and today the Faroe Islands and Greenland). Here I am interested in the long process of devolution of power from Copenhagen starting in the 1840s with the reestablishment of the Icelandic Althingi as a consultative assembly to the Danish king. What are the conditions for state-building and independence? In my view, they are political will, human capital and fiscal independence (Bertelsen 2013; Bertelsen 2014; Bertelsen, Justinussen, Smits 2014). 
And these conditions actually have relevance for the question of Arctic marine invasive species, which make heavy demands on environmental management and scientific capacity for micro-states. The question of marine invasive species and shipping in connection with offshore energy projects, raw materials mega-projects or trans-Arctic transhipment hubs (which Iceland, the Faroe Islands and Greenland have high hopes for), highlights importance of state-, institution- and capacity-building. Iceland, due to intense shipping to and from the island, is already host to a range of marine invasive species (see Thorarinsdottir et al., chapter 6, this volume). These are particular challenges to very small or microstates, even if they have strong human capital as Iceland or the Faroe Islands, and even more so for Greenland with its human capital challenges. Some of my research has touched upon how Iceland, the Faroe Islands and Greenland as very small or micro-states can design and implement efficient comprehensive security policies, where human capital is key. Marine invasive species highlights the topic of bio-security and the threats increased shipping to these areas (which is highly desired by these societies) poses.

\subsection{Linking natural and social systems}

Talking about the importance of looking at the interlinkages of natural and social systems to the Esbjerg workshop and probably to most readers of this volume is "preaching to the converted." However, we are all faced with colleagues and students in either the natural or human or social sciences who are not sufficiently aware of these linkages and their importances, whether scientifically, policy-wise or for the career prospects of our graduates.

Many of the most interesting and important phenomena in the natural or the social world are the results of interactions between natural and social systems. Climate change is probably the most important one right now. Here the human invention of the steam engine and the onset of industrialization and later the invention of the combustion engine led to an explosive rise in the use of fossil fuels which changed the global environment with significant social, political and economic consequences (Stern 2007; Intergovernmental Panel on Climate Change 2013).

Here we are looking at marine invasive species, where an international economic-political phenomenon of shipborne international trade leads to the transplant of species between environments. These invasive 
species can have very important environmental consequences, which again can have important social consequences.

In my view, it is important to introduce students from an early stage to this interaction between natural and social systems in the world. Especially in Europe (without the American liberal arts undergraduate tradition), students overwhelmingly set out studying in narrow fields in natural, human or social sciences and are not exposed to interdisciplinary thinking before a later stage. Introducing such interdisciplinary thinking early is important for scholarly reasons, but also for professional reasons. Very few graduates will find work in pure natural, human or social science. Whether they come from natural, human or social sciences many will find work in the intersection of the natural and the social world, where a thorough grounding in this interaction of natural and social systems will be valuable.

In light of the lack of scholarship on the international politics of (Arctic) marine invasive species despite their importance, I will turn to outline how International Relations theory can guide such inquiry.

\subsection{Theoretically informed International Relations research on invasive species in the Arctic}

International Relations theory is characterized by a number of rich theoretical traditions and their constant debate. The debate between these theoretical traditions is what constitutes to a large extent International Relations as a discipline (see Knutsen 1997 for an overview).

As mentioned above, International Relations as an academic discipline emerged after World War One with the practical purpose of understanding how such an international catastrophe was possible and how to make it impossible in the future. The field was therefore imbued with an agenda of and a belief in the possibility of international progress and cooperation, so the first academic theoretical tradition was liberalism (Knutsen 1997).

However, these beliefs in international progress and cooperation were of course dashed in the interwar years and World War Two. These actions gave rise to the realist school of thought in International Relations, which was much more doubtful of the possibility for international progress and cooperation. Realism was the predominant theoretical school in International Relations until the 1970s, when new liberal schools pointed out the rise of international institutions, interdependence between nations and transnational ties between non-state actors. 
In the early 1990s an alternative school, constructivism, gained prominence pointing out that key aspects to international politics and the international system are historically and socially constructed directing our attention to meanings, discourses and norms (Knutsen 1997).

In the following sections, I will suggest how these theoretical traditions in International Relations each can propose useful concepts and assumptions of actors and causalities for exploring the international politics of (Arctic) marine invasive species.

\subsection{Realism: Power (Transition), China and the Arctic}

Realism is often the starting point for trying to make sense of international politics (although it was a response to liberalism), because it addresses key concepts such as the state, power and the nature of the international system. Looking at the international system, it is clear that the states are very important, perhaps the most important, actors in this system. It is also clear that the states are sovereign and there is no higher authority, there is no world government. There is nowhere to turn for help if a state is attacked by another state, there is no night watchman. Every state must ultimately rely on it self for its survival, even in alliances, which can never be completely trusted. It is a self-help system, and it is an anarchical system in the sense that there is no higher and central authority. Therefore the relative power of states compared to each other and the development of these relative power relationships become very important topics of political strategy and of research (see Knutsen 1997 for overview).

Such a self-help system, where all are left to themselves to survive, gives reason for great pessimism about the possibilities for progress and cooperation, unlike the liberal tradition (which exactly centers on the belief in progress). Realists point back to important authors who have expressed such pessimism concerning progress, as for instance, Thucydides, who in his History of the Pelopposian War has the famous quote that the "strong do what they can and the weak suffer what they must." This $5^{\text {th }}$ century BC quote is not far from China's foreign minister remarking in 2010 about maritime disputes in the South China Sea, "China is a big country and other countries are small countries, and that's just a fact" (Pomfret 2010). Closer to the Arctic, it can be noticed that Norway recently has invested in five guided-missile Fridtjof Nansen-class frigates and will invest in more that $50 \mathrm{~F}-35$ fighters, which probably illustrates other sides to the Norwegian-Russian relationship than the recent 
amicable settlement of the long-standing Barents Sea maritime delimitation dispute.

Also in the Arctic and in the interface between environment and society do we see power imbalances between states play out, where seemingly more powerful greater states try to use their apparent greater power against smaller states. Right now we see a dispute over mackerel and herring quotas between the Faroe Islands, Iceland, the European Union and Norway. Here the European Union is trying to coerce the tiny Faroe Islands by closing its market to Faroese catches. The most famous example of a larger state trying to coerce a smaller state in the Arctic is of course Britain's ill-fated attempts to use destroyers and rammings by tugboats to stop Iceland from enforcing its expanded economic exclusion zones in the Cod Wars of the 1950s and 1970s (Jónsson 1982).

As mentioned, perhaps the main topic in International Relations research on the Arctic today is the rising Asian interest in the Arctic, and especially what China's political goals and strategy in the Arctic are. As mentioned above, China is deeply concerned by Arctic climate change, but that is an area where brute power is completely useless. However of interest to the topic here of Arctic marine invasive species is China's interests in Arctic shipping. China may have important interests in shipping along the Northwest Passage and the Northern Sea Route (the Northeast Passage), which may pin it against Canadian and Russian sovereignty and also environmental concerns concerning marine invasive species. Will China put its shipping interests above Canadian and Russian concerns about marine invasive species and try to coerce these Arctic coastal states from enforcing costly protective measures against this biological threat? The question here becomes whether China (perhaps backed by Japan and South Korea as major shipping nations in an unlikely show of East Asian solidarity) will try to use its power to get its way?

A realist inspired International Relations research agenda on Arctic marine invasive species will therefore look at the states and their policies and how they attempt to use their power to reach their goals and thus, how these factors may influence the potential for and consequences of Arctic marine invasive species. 


\subsection{Liberalism: the importance of other actors and their interests}

Liberalism is the other grand old tradition of International Relations scholarship (with realism). A mainstain of liberalism is the belief in progress and cooperation. Therefore liberalism has a keen interest in the international institutions and transnational relations and economic relations that can lift the world out of the gloomy self-help anarchy of realism. In the anarchic world of realism, the states are the main actors and their interests and strategies are forced upon them by the anarchic system. In liberalism, there is a much wider range of actors, such as international organizations, corporations, civil society movements, political parties, bureaucracies, etc., and the national interest and strategy is not given by the overarching system, but emerges from a domestic political process involving this wide range of actors (see Knutsen 1997 for overview).

Early interwar liberalism was highly optimistic about international progress and cooperation, but in vain, and therefore called utopian. When liberalism reemerged as an important International Relations research program in the 1970s, it was much less utopian and more scientific. It accepted the states as central actors acting under anarchy, but developed important research programs on how states despite anarchy could collaborate and form institutions, and how economic integration created complex interdependence, often unequal, between countries. The attention to a broader range of actors also led to the introduction of the transnational research agenda (Keohane, Nye 1977; Knutsen 1997). Institutions and transnational relations are discussed further below.

The liberal International Relations tradition also makes useful suggestions for studying the international politics of Arctic marine invasive species. Liberalism raises the questions of who are the actors concerning Arctic marine invasive species besides the states? Possible actors could be shipping interests, importers and exporters, ports, fishermen, ship-based tourism operators, local communities, bureaucracies, and civil society organizations at start and end of the shipping journeys in question.

Liberalism reminds us to ask the questions: "What are the interests of all these different international organizations, state and non-state, commercial, civil society, etc., actors concerning Arctic marine invasive species?" "Who benefits from the shipping creating the biological threats, and who pays the price?" "How are the national interests and positions formed and formulated?" This multitude of interests interacts for forming interests and positions at multiple levels. 
The importance of this wide range of actors and their interests for preference-formulation is therefore an important liberal research agenda. This research agenda could look at the role of international organizations as the International Maritime Organization and their efforts to establish a Polar Code along with the Arctic Council and its recent focus on "safe Arctic shipping," how governments form their positions and the role of a multitude of actors in that process.

\subsection{Institutionalism}

A fundamental question for debate between realism and liberalism is whether institutions matter? Do international agreements and international law matter? Can the world progress through agreement from anarchy? Or is realism right, that the world is locked in a self-help system where every state is left to rely on itself and might is stronger than right? The counter-argument would sound that, there are a multitude of international agreements, rules and regulations. But a more sophisticated realist criticism could sound that states decide themselves if and when they want to be bound and they can can and will break the rules if they judge it necessary. Also a sophisticated realist criticism would be that these rules are set by states and they reflect the power relations between states, so strong states get institutions that reflect and promote their interests. The debate continues with instutionalist arguments that institutions develop lives of their own and have an influence beyond the intentions of the states that founded them. Also institutions can outlive the reasons for their creation, so that they start acting on other issues and in other contexts than what they were created for. Finally institutions affect the people working within them. They socialize and create norms and worldviews different from the ones of their founding states. So why do states create institutions? The liberal institutionalists claim that institutions can facilitate cooperation in the interest of selfinterested states acting under anarchy. Institutions validate agreements, create common expectations, facilitate flows of information, address issues of common interest, and make keeping of agreements easier (Krasner 1983, Keohane 1984, Slaughter Burley 1993, Hall, Taylor 1996, Martin, Simmons 2001).

There are important institutions concerning Arctic maritime affairs. The most important is naturally the United Nations Convention on the Law of the Sea, which plays a pivotal role in Arctic international politics. UNCLOS definitely creates common expectations and makes it easier for 
the Arctic coastal states and others to cooperate. However, it is also clear that the strongest Arctic state, the United States, has not ratified the convention for domestic political reasons and can remain outside the convention despite the strong international norm of ratification the convention (the Administration does adhere to the convention). The convention creates the rules of the game for claiming extended continental shelfs, which facilitates the positive interaction and cooperation of the coastal states significantly. However, it remains to be seen if powerful states as Russia will abide by any negative rulings on its claims to extended continental shelf around the North Pole.

The development of the law of the sea saw bitter conflict between NATO allies over this institution, which is of course the Anglo-Icelandic Cod Wars of the 1950s and 1970s. Here Iceland and Britain were in bitter conflict about the content of important international institutions, the exclusive economic zone, and both sides used state violence to enforce its interpretation of the institution (Jónsson 1982). Another example was the Canada-Spain Turbot wars in 1995. The status of the Northwest Passage and the Northern Sea Route (Northeast Passage) are often depicted to be central controversies of Arctic international institutions in the years to come.

So the institutionalist research agenda concerning Arctic marine invasive species would ask questions such as: "Is it possible to design effective international agreements to minimize the risk of Arctic marine invasive species?" "Will different governments around the world commit to such instruments?" "How will agreements come about, and whose interests will they reflect?"

\subsection{Transnationalism (science)}

A part of the liberal resurgence in International Relations theory in the late 1960s and 1970s was the focus on transnational relations. Two of the main authors, Joseph Nye and Robert Keohane (1971), defined transnational relations as the movement of information, goods, people and money by non-state actors across borders. This definition captures a multitude of economic, media, academic, people-to-people, etc., relations. In this Arctic marine invasive species context, we will focus on transnational science and indigenous relations.

The Arctic is characterized by transnational scientific research. Science and knowledge production plays an important role concerning the Arctic. The place of science in Arctic affairs is clear from, for instance, the trans- 
national International Polar Years, the role of the working groups in the Arctic Council and the use of science for legitimizing a place at the Arctic table for non-Arctic states. We see how outsiders legitimate their presence in the Arctic through science (as in the Antarctic Treaty System). The original European observer states in the Arctic Council from the founding were accepted based on their Arctic research traditions. Similarly, the Asian newcomers are entering the Arctic via scientific research.

The strength of transnational Arctic science raises the questions: "What are transnational science relations concerning Arctic marine invasive species?" "Who are the participants, scientists in universities, various kinds of research organizations, corporate researchers, environmental organization researchers, and from what countries?" Arctic science is transnational (as science in general), which raises the question whether there are Arctic epistemic communities and perhaps even integrated into one? An epistemic community is a transnational group of experts and professionals who agree on what the world looks like, what the challenges are and what the solutions look like (Haas 1992). Possible Arctic epistemic communities could be the working groups of the Arctic Council and the International Arctic Science Committee. So this transnational community of Arctic scientists, do they agree on what the Arctic looks like, what the challenges are and what the solutions would be? Does any Arctic epistemic community have an influence on policy? To what extent is Arctic Council policy based on working group recommendations?

\subsection{Transnationalism (indigenous peoples)}

Transnational relations can be about people-to-people relations and the linkages of sub-state actors. Another very interesting research agenda on transnational relations in the Arctic is concerning the indigenous peoples and their struggle to protect their rights and interests. The Arctic Council stands out for the prominent place it accords indigenous peoples as the six permanent participants of Arctic Athabaskan Council, Aleut International Association, Gwich'in Council International, the Inuit Circumpolar Council, Russian Association of Indigenous Peoples of the North, and the Saami Council. The various arrangements for indigenous self-government are among the most important traits of the Arctic. As is clear from the six permanent participants of the Arctic Council, it is clear that Arctic indigenous people organize and operate transnationally. 
Arctic marine invasive species can be a significant threat to the livelihoods of Arctic indigenous peoples. It is therefore an important transnational studies research agenda to describe and analyse how Arctic indigenous peoples could be impacted by and could mobilize and repond to the threat of Arctic marine invasive species.

\subsection{Constructivism}

Constructivism is the important newcomer in International Relations theory. The realist and the liberal schools of thoughts share the assumption that identities and interests are given. This is most clear in realism, where the anarchic structure of the international system forces states to act in a self-help way. In economics-inspirered liberalism, material selfinterest is a given. Constructivists have pointed out that identities and interests are rather socially constructed through social interaction. Actors develop meanings about what their identities and interests are through interaction with other actors. Alexander Wendt made the famous claim that "anarchy is what states make of it" (1992). The constructivist research agenda highlights the power of words, images and norms. How we speak about international politics becomes important because it both reflects established norms and expectations originating in shared meanings, and such talk also is part of an ongoing effort to shape our shared meanings about international politics.

Constructivism makes us think about how we talk about the Arctic, where do shared meanings and understandings come from, and who are trying to change how we talk about the Arctic? The five Arctic coastal states have been collaborating to create a discourse of the law of the sea giving them the rights and the responsibilities to manage the Arctic Ocean. This discourse should create a generally accepted norm that these five Arctic coastal states are undisputedly sovereign in the Arctic Ocean over their exclusive economic zones and their claimed extended continental shelves.

However, these discourses are not undisputed. Most clearly China has been advancing a discourse of China as a "near-Arctic state" with legitimate rights in the Arctic and the Arctic as the "common heritage of mankind." This discourse is a clear example of China trying to influence the shared meaning of the Arctic in order to gain acceptance for its interests and demands. If China can affect the discourse on the Arctic in the direction of the "common heritage of mankind," it will strengthen China's say and role in the region and undermine the discourse of the 
five Arctic coastal states as the rightful and responsible sovereigns of the Arctic Ocean (see Li, Bertelsen 2013 for overview of literature).

Constructivism therefore also suggests a potentially fruitful research agenda on the international politics of Arctic marine invasive species. Constructivism points to the question of how do we talk about Arctic marine invasive species? What are the discourses on these invasive species? How are they portrayed as risks and challenges? Who are blamed? What are the norms about Arctic marine invasive species? What is considered as acceptable behaviour by a range of actors globally and in the Arctic? How have the discourse and norms on Arctic marine invasive species emerged? Who have shaped this discourse and these norms? Who are seeking to reshape this discourse and these norms today? What is the effect of Arctic marine invasive species discourses and norms on policy today?

\subsection{Conclusion}

The Arctic environment is a very fruitful place to study the interaction of natural and social systems. It is an environment, which is deeply affected by human activity around the world through mechanisms as climate change, long-range pollutants or marine invasive species. These environmental changes have significant feed-back mechanisms into local and global environments, politics and economics. The Esbjerg workshop and this volume is all about this natural-social interaction concerning Arctic marine invasive species.

International political and economic processes are important in the original mechanisms and feedback mechanisms of Arctic marine invasive species. Arctic marine invasive species are therefore an obvious International Relations research topic concerning the Arctic and the global environment. Therefore this chapter discusses how International Relations theory can guide research on the international politics of Arctic marine invasive species.

Theory matters. It provides frameworks of assumptions of important actors and causal connections. It guides research explicitly (hopefully), and academic or popular theories guide much debate, analysis and policy-making implicitly. It opens arguments to explicit criticism on its assumptions. It is therefore important to be clear about theory both in scholarship and in debate and policy-making. This chapter tries to assist clear scholarly analysis of the international politics of Arctic marine invasive species and debate and policy-making in broader public and pro- 
fessional circles by suggesting how many theoretical traditions of International Relations can assist in understanding the international politics of Arctic marine invasive species.

\subsection{References}

Barr, S. and Luedecke, C. (eds.) (2010): The history of the international polar years (IPYs). Berlin, Heidelberg: Springer-Verlag.

Bertelsen, R.G. (2013): Historical, current and future microstate security policy making in the High North Atlantic: the Faroe Islands, Greenland and Iceland. Zellen, B.S. (ed.) The fast-changing Arctic: defense and security in a warming world. Calgary: University of Calgary Press, pp. 159-185.

Bertelsen, R.G. (2014): The Kingdom of Denmark - an Arctic history and a complex Arctic future. Korea Maritime Institute.

Bertelsen, R.G., Justinussen, J.C.S. and Smits, C. (2014): Energy as a developmental strategy for North Atlantic microstates in search of independence: creating knowledge-based energy sectors in Iceland, Faroe Islands and Greenland. Hønneland, G. and Jensen, L.C. (eds.) The handbook of the politics of the Arctic. Edward Elgar Publishing

Bright, C. (1999): Invasive species: Pathogens of globalization. Foreign Policy, Fall, No. 116, pp. 50-64.

Haas, P.M. (1992): Introduction: epistemic communities and international policy coordination. International Organization, Vol. 46, No. 1, pp. 1-35.

Hall, P.A., and Taylor, R.C.R. (1996): Political science and the three new institutionalisms. Political Science Vol. 44, No. 5, pp. 936-957.

Heininen, L. and Southcott, C (eds) (2010): Globalization and the Circumpolar North. Fairbanks, AK: University of Alaska Press

Intergovernmental Panel on Climate Change (2013): Fifth assessment report. Geneva: Intergovernmental Panel on Climate Change.

Jónsson, H. (1982): Friends in conflict: the Anglo-Icelandic cod wars and the law of the sea. London: C. Hurst

Keohane, R.O., and Nye, J.S. (1977): Power and interdependence: world politics in transition. Boston: Little, Brown

Keohane, R.O. (1984): After hegemony: Cooperation and discord in the world political economy. Princeton, NJ: Princeton University Press.

Knutsen, T.L. (1997): A history of international relations theory. $2^{\text {nd }}$ edition. Manchester: Manchester University Press

Krasner, S.D., (ed.) (1983): International regimes. Ithaca, NY: Cornell University Press.

Launius, R., Fleming, J.R. and DeVorkin, D.H. (eds.) (2010): Globalizing polar science: reconsidering the international polar and geophysical years. New York: Palgrave Macmillan.

Li, X. and Bertelsen, R.G. (2013): The drivers of Chinese Arctic interests: Political stability and energy and transportation security. Arctic Yearbook, 16pp.

http://www.arcticyearbook.com/images/Articles_2013/

LIBERTLESON_AY13_FINAL.pdf

Martin, L.L. and Simmons, B.A. (ed.) (2001): International Institutions: An International Organization Reader. Cambridge, MA: MIT Press. 
Nye, J.S., and Keohane, R.O. (1971): Transnational relations and world politics: an introduction. International Organization, V. 25, No.3, pp. 329-349

Pomfret, J. (2010): U.S. takes a tougher tone with China. Washington Post. 30 July. http://www.washingtonpost.com/wp-dyn/content/article/2010/07/29/ AR2010072906416.html

Slaughter Burley, A-M. (1993): International law and international relations theory: A dual agenda. American Journal of International Law V. 87, No. 2, pp. 205-239.

Stern, N. (2007): The economics of climate change: the Stern review. Cambridge: Cambridge University Press

Wendt, A. (1992): Anarchy is what states make of it: the social construction of power politics. International Organization V.46, No. 2, pp. 391-425. 



\section{Bioeconomic Strategies to Address Potential Marine Invasive Species in the Arctic}

Linda Fernandez, Virginia Commonwealth University, Richmond, Virginia, USA.

\subsection{Introduction}

The chance to stop non native marine species from threatening and damaging Arctic marine ecosystems still exists. There are economic aspects underlying fundamental efforts to take this existing chance to protect the unique Arctic. Dynamic changes in environmental media conditions (temperature, current shifts, ocean acidification) may widen the range of flora and fauna from outside the Arctic to inside the Arctic to successfully invade through establishing and displacing native Arctic species (Miller, 2014, this issue). Therefore vigilant efforts to address human induced movements of the non native species to the Arctic are needed. This section outlines the manner in which economics and marine biology can work in concert in analysis informing prompt steps towards actual protection from non native marine species before they invade the Arctic. The section includes analysis of existing policies and identification of policy gaps at different scales (international to regional) that can be finetuned and augmented with input from economics to help in steps towards protection of the Arctic marine environment.

Time and space influence not only non native species spread from outside to inside the Arctic but also influence the likelihood of more than one country being involved in decisions that start or stop pathways (vectors) of non native marine species from invading the Arctic. The spatial scale of potential marine species in the Arctic is international. A few remote ports of sovereign countries with Arctic coastline interact economically and ecologically with the rest of the world, with increasingly open access to the Arctic Ocean center. 
Much attention has focused on the pathways the ice melt provides for transport in east and west directions within the Arctic to reduce time and fuel in transit compared to equatorial passages. Additionally, there are the north and south directions to address as a basis of discussing economic incentives to foster any action on potentially invasive marine species in the Arctic. This section draws from a large spatial scale starting south of the Arctic, in the Pacific Ocean near Baja California up through the Bering Sea for several analyses with relevance for the Arctic in terms of the realistic spread of southern non native species to the Arctic (Vermeij, 1991). The analyses tackle open access and incompleteness of existing policy for addressing protection against the biological pollution of non native marine species that may successfully invade where many polluters (responsible for vectors of non native species) can damage without the stewardship for protection from ruin resulting from invasion. The vast spatial scale challenges Arctic protection from marine invasive species. Ideally, policies with economic incentives for self enforcing abatement of invasive species are possible in the Arctic given limits to resources to police internationally the open access scale of threats to Arctic protection from marine invasive species.

\subsection{Four Analyses with Lessons for the Arctic}

Marine invasive species threats of relevance to the Arctic encompass multiple bioeconomic considerations. Four existing analyses that address components of the Arctic challenge across different vectors of nonnative marine species with potential for invasion. As these analyses are based on previously presented models, I summarize the elements of each analysis and information necessary to relate results to relevant Arctic marine resource management.

These are: (1) between trading countries (commercial shipping) in and out of the Arctic; (2) between shipping industry and ports with different information on risk and pollution control; (3) across boating industry and recreational boaters in various countries; and (4) in coastal public waters where aquaculture and aquarium trade may take place. These analyses investigate incentives and policies for more than one decisionmaker of the shared biological pollution problem to prevent non native marine species from hitchhiking on boats, aquaculture inputs through investment and management practices related to shipping, ports, aquaculture and aquarium trade vectors of marine invasive species. The analyses share underlying characteristics of: threats of losses 
due to inadequate policy are imminent and costly; interplay of ecology and economic behavior is clear; knowledge of ecosystems and political economy allows for predictive results; and successful policy integrates remaining risks, uncertainties, ecology, and economic behavior. The bioeconomic analyses rely on applications of game theoretic tools and integrated marine resource management tools for more than one decisionmaker addressing transboundary and potentiall invasive non native marine species with changing risks and uncertainties over space and time affecting long term vigilance for resource protection with and without coordination. All of the analyses can offer guidance for the nascent development of the Polar Code that so far involves the International Maritime Organization (IMO) dealing with the separate sovereign Arctic countries over search and rescue and operation safety without attention yet towards including non native marine species threatening invasion (Deggim, 2013).

Varied motives exist for vigilance against marine invasive species by the decisionmakers in the analyses that can lead to investment choices ranging between pollution prevention and reactive abatement as functions of non native marine species flow and invasive marine species stock, respectively. Some motivators in the Arctic setting include reductions in transportation costs (speed, weight, fuel) that abatement can yield, regulation to avoid potential damages and reciprocity for facing a shared threat. Given this range of motivators, the analyses seek potential international cooperation for matching the scale of management to ecological scale in need of protection.

\subsection{Analysis 1: International Maritime Shipping and Strategies between Trading Countries}

Maritime shipping around the world can bring potentially invasive marine species to the Arctic through ballast water and biofouling of hull and niche locations (propellers, etc) (Miller, 2014, this issue). A summary of analysis (1) between trading countries relying on commercial maritime shipping offers some lessons for stimulating vigilance against marine invaders through these vectors.

In analysis (1), asymmetric incentives across countries in the Pacific Ocean from Baja California through the Bering Sea are based on different pollution control costs, flow and stock effects, ability to pay, and damages of ecosystem changes, and costs to habitat resiliency. Fernandez (2007) develops and applies an integrated bioeconomic game model 
with Pacific Ocean countries along North America deciding simultaneously to minimize expected net costs of abatement and damages due to invasive marine species. Each country's objective to minimize costs is constrained by non native marine species dynamics with a transport matrix of invasive species movement (flow) between ports through ballast water and hullfouling vectors with plausible effects on native species (stock) from successful invasion of the non native marine species. These costs are influenced by both the components of the flow of arrival of non native marine species as well as any accumulated stock of successfully invasive marine species. There are choices over which stage to address non native marine species, ranging from prevention if focused on the flow to reaction (rapid response or eradication) if focused on the stock of marine invasive species after successfully established. These choices are investigated in the model that specifies explicitly prevention costs as a function of flow for ballast water and hull biofouling abatement on ships, monitoring and rapid response on shore. Also, the model specifies explicitly reactive costs are a function of stock for eradication of established marine invasive species.

of prime importance in the analysis is a comparison investigating the economic incentives of coordinated protection versus unilateral action by solving for noncooperative and cooperative game solutions from the applied bioeconomic game modeling. The comparison of game solutions help to articulate ecosystem management strategies at an international scale as the decisions are direct functions of the stock of marine resources. Empirically, there are true asymmetries in costs and damages in the North and South with non native marine species moving in both directions from continual maritime trade transit in those directions. Pacific coast ports shipping frequency and volume help define the transport matrix of shipping with marine invasive species vectors of ballast water and hullfouling over space and time. This matrix is a part of the dynamic equation that defines the movement of nonnative marine species that are potentially invasive in both directions. Data and growth equations for two marine invasive species, Bugula neritina and Nemertea (ribbon worm) are referenced from Kuris et al. (1992ab) and Haygood (2000). The Bugula neritina moves from north to south through the vectors and Nemertea moves from south to north.

The two marine invasive species have varied impacts that are taken into account in the analysis, as it influences the asymmetric incentives to motivate any action on marine invasive species. Commercial value of native shellfish species damages in Canada and recreational value as damages from Nemertea are referenced from Kuris et al. (1992ab). 
Pharmaceutical value of Bugula neritina is referenced from Haygood (2000) as an potential commercial value from harvesting the invasive bryozoan (Bugula neritina). Empirally estimated preventative and reactive abatement cost functions for hull maintenance (cleaning) along with antifouling paints on the ship hull and are based on data from Taylor and Johnson (2003). Likewise, on board and off shore ballast water treatment cost functions are estimated with data from Tamburri et al. (2002). Note, the reason for this form of treatment is because most vessels moving along the South to North space would not motor out beyond 200 nautical miles to carry out open water exchange due to time and fuel costs that would be expended instead of an on board alternative that does not require the significant distance from shore to carry out. An economic incentive that motivates the commercial shipping sector separate from any potential regulation is the chance for fuel savings from strategies to prevent hull biofouling such as hull maintenance (cleaning and drydocking) as well as antifouling paints (Younqlood et al. 2003). For example, $30 \%$ reduction in fuel and expenditures is possible from bearing the abatement costs from investing in antifouling coatings and management practices included in the preventative cost functions of the study. Additionally, the on board treatment of ballast water saves in time and effort to motor out beyond 200 nautical miles away for open water ballast exchange, the option suggested under the 2004 IMO Convention for the Control and Management of Ship's Ballast Water and Sediments.

The comparative analysis is able to assess quantitatively between several options: cooperation and prevention, cooperation and reactive strategies, noncooperation and prevention and noncooperation and reactive strategies. Of the four options, cooperation with prevention is found to be the best at cost minimizing between the countries by reducing damages from Nemertea with higher benefits from harvest value of Bugula neritina and fuel savings for the region. This result can be the basis of benefit sharing across trading participants to offset abatement costs with the generated savings and actual revenues from the harvested species.

\subsection{Analysis 2: Port and Ship Incentives for both Ballast Water and Hull Fouling Policy}

Analysis (2) focuses on the shipping industry and ports with different information on marine invasive species risk while both may be aware of potential damage from both shipping vectors of invasion (ballast water and hull fouling). The shipper clearly knows more than the port about 
any abatement of non native marine species he has undertaken onboard in the form of treating ballast water and abating hull fouling. This is the premise of the analysis by Fernandez (2008) in order to design policy options that take into account these variations in information between relevant participants in the potential controls of shipping vectors of marine invasive species to the Arctic.

Another premise for the analysis is that ballast water has received attention at the international level translated into guidelines from the IMO for numerical limits on marine invasive species concentrations in ballast water through the International Convention for the Control and Management of Ship's Ballast Water and Sediments of 2004. Instead of a policy similar to the IMO Convention on ballast water and sediment, there is a ban on tributyltin coating, that had been used in the past by shippers to control biofouling. The coating was found to harm to surrounding marine life, thereby leading to the International Convention on the Control of Harmful Antifouling Systems on Ships in 2001. There exist some draft guidelines on anti fouling practices rather than a formal international policy on the order of the ballast water convention of 2004 .

In analysis (2), both vectors (ballast water and hull fouling) and the information divide between shippers and ports require the same number of policies to match the vectors and information issue plaguing public good protection from marine invasive species. The analysis proceeds to evaluate technology subsidies and ballast water reporting fees in a manner that assesses the effectiveness in combination with liability rules from maritime ship safety law of the IMO. The numerical analysis helps in exploring the possibility to finetune existing policies working in combination, including the maritime ship safety liability rule of the IMO, the tax in the form of the port access fee and west coast ballast water reporting fee and the subsidy from the U.S. Coast Guard technology assistance cost share and grant program for implementing new abatement technology. Results from the analysis show that combining a subsidy with liability or a tax with liability can help address information problems and uncertain damages. Liability influences the distribution of benefits between the shipper and the rest of society, but it does not influence the levels of abatement for investing in both abatement of ballast water and hull fouling. Subsidies and taxes achieve the same level of abatement and economic welfare. The difference is shipper profits are lower with taxes.

The following suggestions from analysis (2) can apply in the current drafting of the Polar Code that needs to augment the search and rescue and operational safety topics to include environmental concerns such as 
marine invasive species. Aim to tie current technology subsidy for ballast water treatment to liability and potential damages. Also, tie current port reporting fee to liability in a manner such that the QUALSHIP 21 program of U.S. Coast Guard rewards vessels that have complied with international safety and environmental requirements by reducing the inspection frequency.

Additionally, the NZ 1993 Biosecurity Act, Section 154, an existing policy with a variation of combining a liability rule with a tax can offer more experience in this effort (Floerl, 2014, this issue). That Act has a penalty for incorrect information about abatement and disobeying directions that includes fines and possible prison time. There is room to explore combining such policy instruments beyond the public resource manager and regulator of a country to include viable entities such as maritime shipping insurance companies too.

\subsection{Analysis 3: Recreational Boats}

Analysis (3) looks beyond commercial maritime shipping to across the boating industry and recreational boaters in various countries noting their vital role in addressing the marine invasive species threat to the Arctic. Recreational boaters constitute a hull fouling vector for hitchhiking marine invasive species to the Arctic. In analysis (3), the boating industry refers to the supply side of abatement control options for hull fouling on recreational boats. The empirical focus of analysis (3) centers on the cost and availability of supplies and services to control marine invasive species on recreational boats traveling along the West Coast of North America (including Mexico, U.S. and Canada) (Johnson and Fernandez, 2011). Specific attention is placed on comparing metal based and non toxic anti fouling paints. Metal based paints do not have an international policy like the International Convention on the Control of Harmful Antifouling Systems on Ships in 2001 that implemented a ban on tributyltin antifouling paints for hulls. The present concern has been with copper based antifouling paints posing a hazard to marine life beyond the target marine invasive species as hullfouling (Johnson and Fernandez, 2011). The ablative properties of copper based paints results in copper build up from deposition to the benthic layer below where boats are situated.

In order to conduct this analysis, Johnson and Fernandez (2011) conducted a survey of various entities of the boating industry to generate data. Managers of marinas, harbors, yacht clubs, boat repair yards, in- 
water hull cleaning companies, slip liner companies and boat lift companies participated in the international survey of the boating industry conducted by Johnson and Fernandez (2011). Slip liners and boat lifts are two alternatives to anti fouling paints to deter biofouling on recreational boats. The survey results indicate $48 \%$ of boats rarely leave the marina where stationed and for that reason the rate of deposition of metal based paints can be quite large. For those stationary boats and protection at the marinas, non toxic (non metal based) anti fouling paints are the best option, if available. With the $48 \%$, focus is on preventing the heavy metal deposition and there is less of a threat from these boats transporting marine invasive species if they stay in the marina. Given that $48 \%$ of boats never leave their own harbor, performance bonds and "evergreen leases" for slip space are viable policies for implementing nontoxic coatings to avoid exceeding Total Maximum Daily Loads on copper in harbors that are the focus on many marinas along the Pacific Coast of North America (from California through British Columbia).

Statistical analysis of the survey data indicates the following results. Awareness of nontoxic coatings is statistically significant in influencing anti fouling coating choice. Cost and location are not statistically significant for recreational boaters. Education has positive influence on choice of nontoxic coating. For recreational boats that do engage in longdistance trips by leaving the marina, there is a higher risk of transporting marine invasive species via hull fouling and less risk of contributing to deposition of metal based coating in benthic layer below marina slip. Therefore, the availability of metal based paints for those recreational boats proves a viable option. For boats leaving harbors, avoiding additional fuel and speed loss costs from hull fouling offers incentive to regularly remove biofouling whether they are involved in racing recreation or less rapid travel for leisure.

A comparison of the calculated average cost per foot to use each type of antifouling paint included in the analysis indicates the most widely available copper based anti fouling paints are cheapest followed by zinc based and subsequently epoxy (the nontoxic) coating that is available. When expected service life is factored in, epoxy based coatings gain in cost effectiveness against heavy metal based paints (copper and zinc) due to the lasting twice as long the metal based options in terms of lifetime prior to replacement. The capacity of industry to service nontoxic paints needs expanding everywhere. 


\subsection{Analysis 4: Coastal Waters, Aquaculture and Other Leasers}

Analysis (4) is conducted by Fernandez (2011) in coastal public waters where aquaculture and aquarium trade may take place. In this setting, the need for coordination between aquacultural operators and others similar to slip leasers in a marina is obvious from the potential harm from spreading problems in common space. Here, shared marine invasive species risk among users is a quantifiable component to include in decisions by leasers of the public coastal space in how they use and maintain that space to prevent marine invasive species from plaguing their space and surrounding connected space.

With the absence or incomplete presence of a separate policy to address marine invasive species in these coastal shared setting, a remedy may be through existing lease arrangements by instilling an environmental bond where upfront payment of a lump sum to cover any potential impact is part of the requirement in obtaining a lease. Coordinated not unilateral action will help to prevent damage from aquaculture, aquarium trade in coastal area and marina slips and foster long run positive revenues not losses if avoid the marine invasive damages. The presence of environmental bonds imposes a cost on potential damage that is forfeited if the damage occurs. However, the bond is refunded for damage avoided by vigilant abatement effort in each leaser's own space. Cooperation increases with increased bonds or deposit-refund amounts because there would be more to lose if abatement is not done and the threat is larger to all leasers. Existing leases can be fine-tuned for incentives, such as along lines of the U.S. Leaking Underground Storage Tank Trust that has addressed ubiquitous threats to water quality throughout the country in a manner that insures any harmful impacts are fully financed with upfront and continuous pooled resources from the commercial industries depending on the tanks for their livelihood.

\subsection{Conclusion}

The four analyses were undertaken with attention towards integrating marine ecology and economic components for analytical gain in assessing viable strategies over several vectors of marine invasive species to impact the Arctic. The analyses provide comparisons that help gauge tradeoffs between lack of coordination and coordination when the scale of the vectors extends internationally and responsiveness of policy or 
abatement action may be at different scales to compare. The analyses also indicate tangible economic incentives in various forms that directly influence the timing and scale of response towards stewardship of protecting against marine invasive species. Some incentives are identified through the comparisons of net benefits to preventative versus reactive policies and action to combat marine invasive species. Cost savings in the form of less fuel, weight and lost time in transit by commercial and recreational marine vessels may be realized through responses to policies to address ballast water and hull biofouling vectors of marine invasive species, provided the policies stimulate those cost savings. Economic incentives are also shared in terms of the avoided risk in coastal public space shared by aquaculture producers or leasers in a marina faced with a shared threat of marine invasive species changing their productive space once invaded. A common finding in the analyses is the gain from coordination at various scales.

These analyses can inform the Polar Code currently under development. The Polar Code can contribute to acting on the chance to stop marine invasive species in the Arctic. With that international policy focused on the special ecological settings of the poles, there is a potential to match the scale of policy to the scale of the marine invasive species threat, that is, the international scale. Cooperation is a necessary condition among the Arctic countries endowed with ports that are recipients of the vectors mentioned in the four analyses summarized in this section for any efforts to address marine invasive species threat to the Arctic involving the rest of the world as well.

\subsection{References}

Deggim, H. (2013). Polar Code Development at International Maritime Organization. Presentation to Arctic Summer College, webinar, July 22, 2013.

Fernandez, L. (2007). Maritime Trade and Migratory Species Management to Protect Biodiversity. Environmental and Resource Economics 38:165-188.

Fernandez, L. (2008). NAFTA and Member Country Strategies for Maritime Trade and Marine Invasive Species. Journal of Environmental Management 89: 308-321.

Fernandez, L. (2011) Economic Incentives to Prevent Aquatic Invasive Species in Wetlands. Canadian Journal of Agricultural Economics 59(2):281-294.

Johnson, L. and L. Fernandez (2011) A Binational, Supply-side Evaluation for Managing Water Quality and Invasive Fouling Species on California's Coastal Boats, Journal of Environmental Management 92:3071-3081.

Haygood, M. (2000) Microbial Symbionts of Marine Invertebrates: Opportunities for Microbial Biotechnology, In: Bartlett, D. (ed.) Molecular Marine Microbiology, Horizon Scientific Press, Norfolk. 
Johnson, L., Miller, J. (2003) Making Dollars and Sense of Nontoxic Antifouling Strategies for Boats. California Sea Grant College Program Technical Report, No. T-052, San Diego.

Kuris, A. (1992a) A Review of Patterns and Causes of Crustacean Brood Mortality. In: Wenner, A. and Kuris, A. (eds.) Curstacean Egg Production, Crustacean Issues 6. Balkema, Rotterdam.

Kuris, A., Lafferty, K. (1992) Modeling Crustacean Fisheries: Effects of Parasites on Management Strategies. Canadian Journal of Fisheries and Aquatic Sciences 48: 559-568.

Tamburri, M., Wasson, K., Matsuda, M. (2002) Ballast Water Deoxygenation can Prevent Aquatic Introductions While Reducing Ship Corrosion, Biological Conservation 103: 331-341.

Vermeij, G (1991) Anatomy of an Invasion; the Trans-Arctic Interchange. Paleobiology 17: 281-307.

Younqlood, J., Andruzzi, A., Senaratne, W., Ober, C. Callow, J., Finlay, J., Callow, M. (2003) New Materials for Marine Biofouling Resistance and Release: SemiFlourinated and Pegylated Block Copolymer Bilayer Coatings. Polymeric Matter Science and Engineering 88: 608-609. 



\section{Invasive Species Management Strategies: Adapting in the Arctic}

Brooks A. Kaiser, University of Southern Denmark, Esbjerg, Denmark.

\subsection{Introduction}

Invasive species have, to date, been a relatively minor concern in the Arctic marine ecosystems because the harsh environmental conditions that stem from a combination of generally low temperatures and extreme fluctuations in seasonal light and food availability. As discussed in Gill (Chapter 1 of this volume), the rapid pace of climate change in the Arctic is bringing new urgency to concern over the introduction of nonnative species and their potential threats to the marine environment and its economic productivity.

The same characteristics that have previously made the Arctic less open to the establishment and spread of invasive species are ones that make the potential problem so expansive. At stake are unique species and co-evolved systems that have taken millennia to develop. Small perturbations in the fragile Arctic ecosystems are likely to have outsized impacts both ecologically and economically. Even beyond initial polar environmental concerns, comparisons of Arctic and Antarctic systems have established that conditions in Arctic systems make it more likely that the Arctic will experience greater effects from human activity than the Antarctic due to lower alkalinity, enhanced warming, and nutrient limitations (Shadwick et al., 2013).

Warmer temperatures and decreases in sea-ice are bringing increased economic opportunities to the Arctic (Economist, 2012). Efforts to exploit these opportunities are increasing human presence in the Arctic and increasing both the vectors of introduction of non-native species and their intensity in terms of numbers of potential introductions, which both contribute to the ability of a new arrival to establish and evolve into an invasive species (Simberloff, 2009; Johnston et al., 2009). 
With the changing threat in mind, this chapter focuses on the human dimensions of invasions, both from the behavioral aspects that affect them and from the policy perspective of trying to manage them. I consider that the path from a non-indigenous species to an invasive species problem in a new area such as the Arctic is a process, and that this process provides differing policy intervention opportunities that incorporate both ecological and human behavior, i.e. bio-economic modelling, in order to minimize expected damages from an invasion. When the species cross national borders, additional policy challenges arise.

Some challenges, like the Red King Crab and the Snow Crab introductions in the Barents Sea, are already attracting concern and attention in both scientific research and management efforts within and across national borders (see Sundet, Chapter 5 of this volume), but others will be more difficult to spot and manage (see Floerl, Chapter 4 of this volume) though they may have even more devastating impacts. The biology of invasions often involves lags, uncertainties, and non-linear relationships that are not easily understood. Even our ability to detect the arrival of new species and the beginnings of an invasion are functions of human behavior that should be accounted for in policy for the Arctic.

Discrepancies across species' threats are matters of both ecological uncertainty, in terms of not knowing of a threat, its presence, or the expected changes to the system it will bring, and of policy implementation. Policy implementation will necessarily vary because of the ecological uncertainty, but also can vary if stakeholders differ in the expected damages (or benefits) they will accrue from the invasion. These problems require coordinated bio-economic understanding to resolve.

\subsection{A Brief Overview of Species Introductions in an Arctic Context}

\subsubsection{Effects of the Age of Pacific Exploration}

While at first thought, remote tropical Pacific locations like the Hawaiian Islands and The Arctic Ocean and its coasts may not seem to have much in common, the cautionary lessons of the tropical Pacific with respect to invasive species are likely to be of direct use to the coming concerns in the Arctic. With some of the very same explorers - James Cook and George Vancouver, for example - advancing the paths into both locales in the late $18^{\text {th }}$ Century, and direct links between locales from the whaling industry, direct parallels can be explored for insights. We can also 
look to other species and locations for trends that can guide improvements in invasive species management in the Arctic.

At long distances from neighboring land and/or without favorable current paths, the Pacific Ocean had formed a barrier around places like the Hawaiian and Galapagos Islands that led to the evolution of unique and fragile ecosystems which transportation advances have eroded, with the pace continuing to accelerate today with shortened sea- and air- routes.

The changes in the Pacific have been dramatic, rapid and transformative. While some of the species introductions causing the changes have been accidental, many have been intentional. For example Captain Vancouver's introduction of cattle to Hawaii, and royal tabus on these exotic and unfamiliar creatures ${ }^{7}$ protecting them and allowing them to multiply rapidly, led to the destruction of the forests and reductions of the water supply (Kaiser, 2014). The Galapagos now have more introduced plant species than they do native species. The count for introduced plant species is over 600 , meaning an average rate of introduction of 1 per year since the first western contact in 1535, compared to a natural rate of introduction estimated at 1 species every 10,000 years (Reaser et al, 2007).

Similarly, due to sea-ice, Arctic marine ecosystems have evolved with a level of isolation that renders them unique and fragile as well. Successful species introductions have undoubtedly been slowed more by differences in climate than differences in human behavior toward introductions of new species. For example, across all known introductions of herpetological species globally since 1850, intentionally introduced species have occurred earlier than later. (Figure 1). This should be rather unsurprising, since introductions that have net benefits to at least some stakeholders are likely to be directly undertaken by humans rather than left for more random chance opportunities for a species to hitchhike to a new environment. The Red King Crab introduction into the Barents Sea by Russia is an example of just such an intentional introduction made for market benefits (Orlov and Ivanov, 1978) (see Sundet, Chapter 5 in this volume).

While intentional introductions are generally driven by private assessments of expected net benefits to those invested in the introduction, these may well be in conflict with social measures of net benefits. In the case of the Red King Crab, for example, not only are there ecological side effects to benthic communities that were ignored in the initial decision

\footnotetext{
7 The only land mammal to arrive in Hawaii without human-assisted transport was a bat species. Polynesian arrivals in the $1^{\text {st }}$ millennium $\mathrm{AD}$ brought pigs, rats, dogs, and chickens, and began the ecological changes that were intensified by western contact (Kirch, 1985).
} 
to transplant the species but there are also potential market effects from the expansion of crab production. Alaska fishermen today complain that prices are falling due to illegal Russian catch and sales (Stewart and Tallaksen, 2013). While this is bad for Alaska fishermen, it is good for consumers of crab, and the net market impacts are not estimated here. In order to capture the full economic value a proper management system has to be in place that incorporates these conflicting incentives. With such incentive based development, the distribution of producer and consumer surplus can change over time in accord with maximum sustainable economic value.

Accidental introductions may not be aggravated by the way that the benefits of intentional ones drive a wedge amongst stakeholders trying to manage an invasion, but they still require coordinated community action at a scale relevant to the full bio-economic context, including any markets or non-market values for the threatened resources, in prevention and control. If one community, for example, finds a new species introduction becoming an invasive species problem, then neighboring communities will benefit from an early interception of the problem (See Fernandez, Chapter 10 in this volume).

\section{Figure 1: Cumulative introductions of known herpetological species worldwide} since 1830

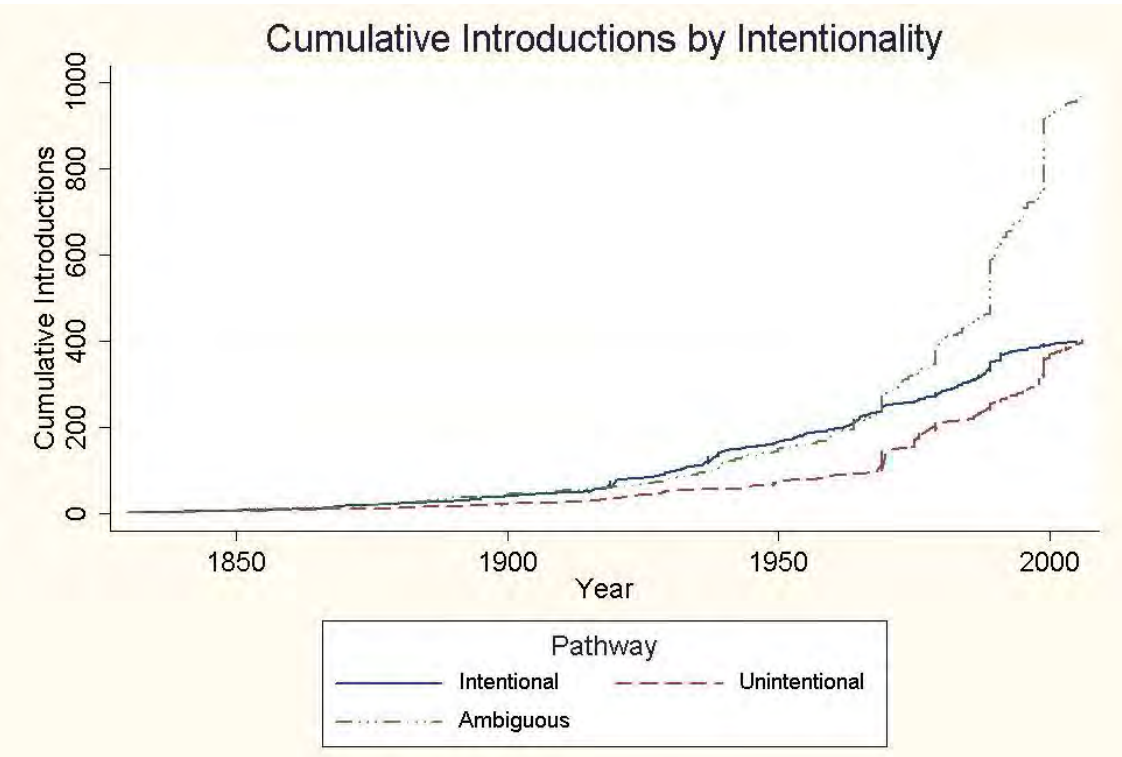

Species data is from Kraus (2009). The timing of intentional introductions precedes that of unintentional and ambiguous cases. This is likely due to the fact that intentional introductions are likely to have expected benefits to the parties responsible for the introduction, regardless of overall expected social costs. 
All actual and potentially affected parties, should, therefore, be willing to aid in the costs of such intervention, but may, for budgetary or other reasons, decline to "do their part," exacerbating the problem for both invaded and threatened communities.

As climate evolves to be more accommodating of new species introductions (see Miller, Chapter 3 in this volume), we expect the rate of initial introductions, and their ability to take hold and transform into invasive species, to occur.

\subsubsection{Anthropometric Correlates of Invasive Species Movements}

The challenges of human survival in the Arctic meant that much early exploration ended disastrously, such as the Franklin Expedition of 1847. (Beattie and Geiger, 1987). These human invaders were fended off by the sea-ice. On the other hand, native communities have co-evolved with the Arctic environment over the past several millennia, with several developing subsistence economies dependent in large part on marine mammals such as seals, walrus, and whales. More successful Arctic excursions adapted to the environment. Roald Admunsen explores both the Arctic and Antarctic after learning from native Inuit how to survive and travel through arctic conditions (Katz and Kirby, 1991). Fridtjof Nansen builds a ship, the Fram, that he can purposefully let freeze into the Arctic ice in his attempt to reach the pole by letting the currents take him there. While he did not reach the Pole in this manner, he did survive a lengthy voyage, which was managed in great part by unexpectedly meeting up with Frederick George Jackson, after 1.5 years in the ice, on June 17, 1896 (Figure 2). In some cases, propagule pressure does not need to be very high to dramatically increase the chances of successful survival in a new environment (See Miller, Chapter 3 and Floerl, Chapter 4 in this volume). 


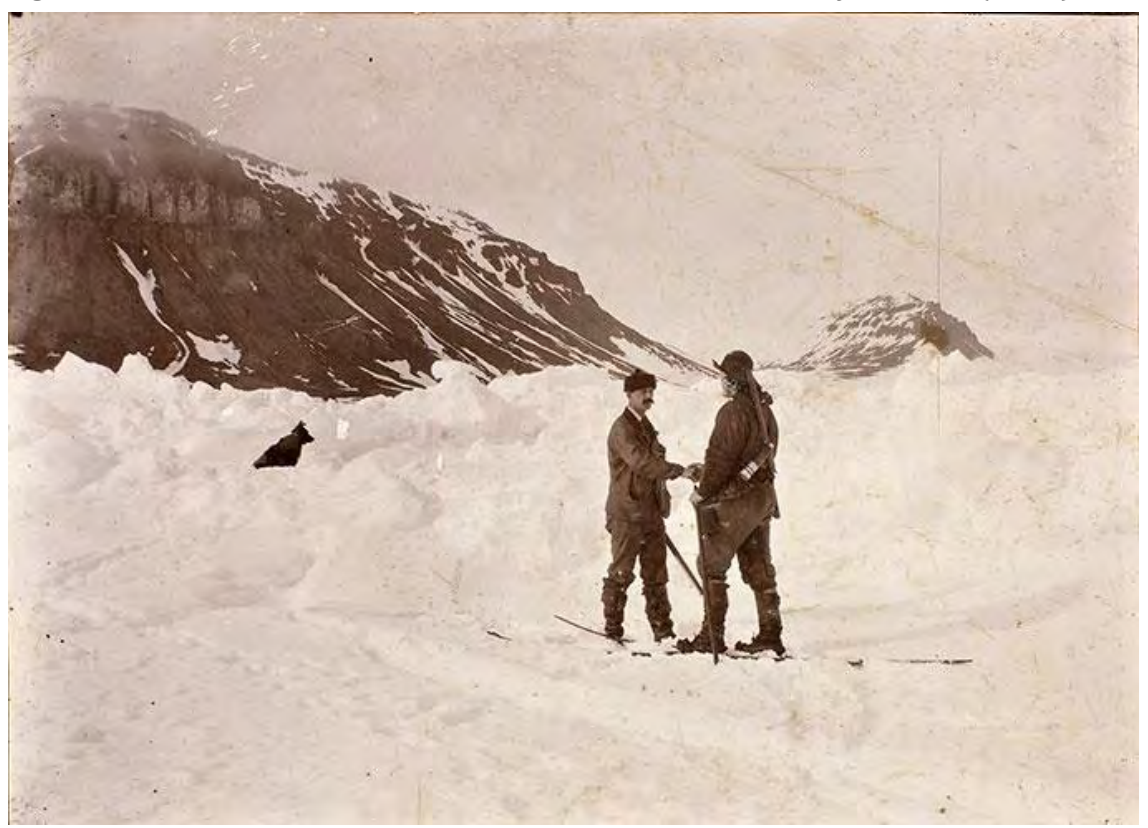

While the rate of both accidental and intentional introductions is an increasing function of trade and travel to new locations, this is not the only important factor. The movement of some species may have high external costs, while that of other species may not. One must consider the biology and the economics together to get a clear and full picture of the threat.

\subsection{Management Overview of Invasive Species: Options for threatened states}

\subsubsection{Opportunities for Intervention}

Figure 3 illustrates the interconnectedness of policy options with the biological process of invasion and time. Actions to reduce damages from invasive species may begin before the arrival of any new species to an area and continue through the spread of a new species to its biological carrying capacity. In the case of marine invasive species, limited management interventions may be possible after the arrival of a species because the environment is often more difficult to manage than for terrestrial systems. These limitations make it perhaps more necessary to consider the full spectrum of policy options when making decisions about 
prevention because the costs of control may be so prohibitively high. See, for example Niemi et al, Chapter 7 of this volume; Floerl, Chapter 4 of this volume; Bax et al, 2001; Ruiz and Carlton, 2003.

Figure 3: Integrated management of Biological Invasions
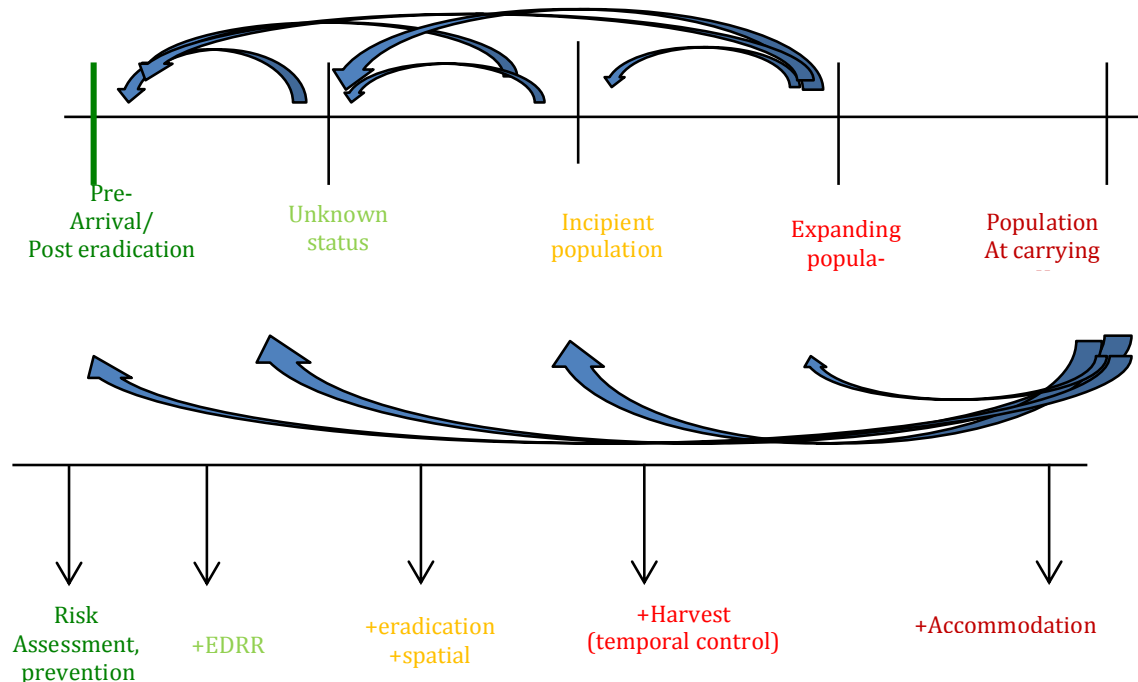

\subsection{Prevention and Early Detection (ED) and Rapid Response (RR) Strategies}

At low potential population levels, when a potential invader has not yet become a problem, the management options should focus not only on prevention of arrivals at obvious points of entry (e.g. ports, ship hulls) but also on a process of early detection (ED) and rapid response (RR) that also includes expected damages and costs of investigating the invasion in the decision-making (Kaiser and Burnett, 2010).

Preventative measures are imperfect, probabilistic, and will fail. Prevention can only be expected to buy time, rather than provide an impenetrable shield around an ecosystem. Early detection systems are monitoring systems that increase the likelihood of identifying the arrival or incipient population of a potential invader. Rapid Response systems provide actionable responses to eliminate or spatially contain the new invasion. Together EDRR can function to protect ecological and economic assets at risk in relatively low cost ways. For example, preventative efforts to keep the Brown Tree Snake arriving in Hawaii from Guam have knowingly failed several times, and may have unknowingly failed others. 
EDRR targets these unknown cases by enlisting the public's help through awareness and a hotline for reporting snake sightings and then deploying a team of trained snake spotters for several weeks' worth of night searches in the region of the sighting. In this case, as sightings occur in places that humans use, they are more likely to accrue damages to humans from bites and other interactions than snakes in other areas, so the damage minimization process is built in (Kaiser and Burnett, 2010). There are, of course, other potential ecological damages that are separate from human interactions which this sort of EDRR will systematically miss. Awareness of such concerns is important to policy efficiency and will be particularly important in the Arctic where direct human-species interactions are not likely the primary source of damages from invaders (see valuation discussion below).

Policy Options for prevention can be categorized as either incentive based or command-and-control. Command and control options are regulation via "green/white" lists that include all species that may be introduced to an area (knowingly) or "red/black" lists that include all species that must be kept out of an area (knowingly). Note that these policies only target intentional introductions. Green lists are less permissive than red lists in that they ban the introductions of species about which little or nothing is known. These species may have net benefits from introduction (e.g. many agricultural products have been introduced around the globe with positive net gain) but cannot occur under the policy regime of a green list, potentially stifling growth and economic prosperity. On the other hand, the green list system is better at protecting the status quo against unexpected consequences. Green lists, being less permissive, may be more difficult to negotiate across borders and may lead to increases in smuggling, which makes prevention more costly (Burgiel et al, 2006; Wittenberg and Cock, 2001).

Incentive based regulations, e.g. those targeting economic behavior such as taxes or subsidies, focus on aligning the interests of those who are causing the introduction with the overall expected social damages. As such, they are more targeted policy than the command and control options, such as prohibitions, technology mandates and quotas, and can therefore in theory operate at lower costs to society by avoiding costs from e.g. hierarchical management and control, information gathering, and monitoring and enforcement. Such incentive based systems include certification systems, under which any new introductions must be researched and shown to lead to acceptable expected costs before the introduction can be made, and liability or insurance systems, where the 
expected costs are borne by the introducers. Again, these regulations focus mainly on intentional introductions (Inglis et al, 2012).

In the Arctic, intentional introductions may not seem like the primary pathway for new invasions. However, with approximately four million people inhabiting the Arctic (ACIA, 2004), the case of the Red King Crab suggests that there are likely gains to be had from introducing new marine species. As the climate changes, some species that already spend some portion of the year in the Arctic may expand both their spatial and temporal ranges at the expense of existing endemic ice-obligate and iceassociated species (Moore and Huntington, 2008). Some of these endemic species are hunted for subsistence, and communities might look to ways to enhance marine productivity. Or, as with the Red King Crab case, individuals or nations may find the climate changes in the Arctic conducive to the introduction of other marine resources. Thus some consideration to policy should be given to limiting intentional introductions.

While the above discussion focuses on reducing impacts from intentional introductions, policy options aimed at accidental introductions such as would occur through ballast water exchange or hull fouling are clearly important policy tools needed in the Arctic. These are discussed at greater length in Section 2 (Miller, Floerl) and Chapter 10 (Fernandez) of this volume. In short, these policies need to focus on regulating the bio-economic conditions rather than just the economic or ecological ones independently. For example, ships that are only in transit through the Northern Sea Route (or Northwest Passage, eventually) may not need as stringent controls as those that are stopping at ports along the way. Additionally, slow moving or stationary equipment, like the recreational boats that might eventually dot Arctic waters for tourism and leisure, or oil rigs set to the ocean floor, are likely to need more attention than faster ships that are used for trade who will spend time neither accumulating nor discharging many species in similar waterways.

\subsection{Control (Spatial Containment and/or Population Reduction)}

If prevention and EDRR fail, so that an incipient, self-sustaining population exists in the new location, the option of limiting intervention to controlling either the spatial extent of the invasion or the biomass levels associated with the invasion become other possible intervention policy options. This is the stage of intervention we are now at with the Red King Crab. While efficient policy that minimizes expected net damages 
would consider the costs and benefits of the Crab across time in terms of its likely movements into new areas, markets for crab over time, and ecological and/or economic damages from the crab to other species and the whole benthic ecosystem, existing policy has not been so thorough. The result is that the crab continues to spread eastward and has become a market good upon which livelihoods are beginning to depend in Norway and Russia (Jørgensen and Nilssen, 2011). This makes future management decisions even more complicated as one weighs more easily measurable gains from the crab against difficult valuations in changes to the ecosystem and its productivity. The 2007 management decision to have an open access fishery for crab west of $26^{\circ} \mathrm{E}$ in an attempt to stem the invasion does not appear to be successful (Falk-Petersen et al, 2011).

\subsubsection{Adaptation}

As there are significant economic benefits to the harvest of the crab, and the crab is already being managed in both its native range (Alaskan waters) and its expanded Russian and Norwegian range with quota systems that work to limit harvests so that the fishery is sustainable over a long time horizon, the long term control strategy will likely be one of fisheries management for stable economic outcomes focusing on producer and consumer surplus from market transactions rather than for full ecological considerations that might include protecting biodiversity values or ecosystem services with direct or indirect values to society. In adaptation to the new conditions, the one-time chance to preserve the benthic ecosystem associated with the newly invaded habitat will be lost, at potentially tremendous cost.

This describes one of the biggest concerns of invasive marine species in the Arctic: that we will lose the stock of nature built up over millennia and replace it with a less diverse, less resilient system. The costs to society might be high and yet difficult to measure. We turn now to discussions of valuation and the role of valuation in policy making for invasive species.

\subsection{Valuation of what is "at stake"}

It is important to realize that just as the ecological consequences vary with the level of invasion, the expected costs and benefits of interventions are also dynamic. Any calculations of policy costs must be contingent on the stage of invasion and level of prevention and/or control desired over the long run. 
Failure to make policy decisions regarding invasive species over the long run can be extremely costly to anyone who garners any sorts of value from the threatened ecosystems - privately or socially. Decisionmaking may be through private cooperation or public management, and may be local, national, regional, or global, depending on the bioeconomic conditions of the threat. In the worst case scenarios, any money or effort spent on prevention or control is swamped by the ecological changes and the end tally for the damages is higher than if no intervention were attempted at all (Kaiser, 2006). Unfortunately the piecemeal funding opportunities for invasive species management often make this all too real of a problem (Kaiser and Burnett, 2010). One way in which to avoid this problem is, like Nansen, to work with nature and the sea-ice and ecology rather than against it. A dollar spent on spatial containment of a new invader, keeping it, for example, east of a certain longitude, such as Norway seeks to do with the Red King Crab (Sundet, Chapter 5 of this volume), may bring much more success than reduction in biomass across the entire range, for example, if there are spatially differentiated costs or benefits from protecting the existing ecosystems. On the other hand, if the ecosystem is widely similar, it may be more efficient to simply target biomass reduction at any location than to worry about spatially controlling the spread (Frid et al, 2013). In any case, one must determine the values of the assets one wishes to protect through the invasive species management policy as well as the costs of the intervention as functions of the invasion level. It is generally far cheaper, for example, to remove invasives from a large concentrated population than it is to hunt down the last specimen of an invader across a wide range.

These considerations lead to a balancing act between present and future actions and their consequences. Optimal policy would provide intervention activities today (prevention, EDRR, and/or control) until the last dollar spent on the intervention, was just equal to the marginal benefit of that dollar spent, not only in the current consequences but also in the future expected costs. These future expected costs are based on the population that is left remaining after current intervention activities are undertaken and its ability to reproduce and spread, and the damages from those future ecological changes, and the future costs of intervening to manage them. (See, for example, Burnett et al., 2007). In addition, policy expenditures across intervention options should also equate marginal benefits and costs. In other words, the last dollar spent on prevention activities should bring the same expected return as the last dollar spent on control/containment policies for a species, or one could im- 
prove outcomes by moving resources from the lesser productive policy to the more productive one. (Burnett et al., 2008).

\subsection{Valuation techniques for Non-Market Resources Damaged by Invasive Species}

There are two types of valuation techniques that economists have developed (and continue to develop) to address valuation of non-market amenities such as most of the ones generated by marine resources and ecosystems in the Arctic (see, e.g. Garrod and Willis, 1999; De Groot et al, 2002; Freeman, 2003; Atkinson et al, 2006; Bennett, 2011; Barde and Pearce, 2013 for overviews and cases of environmental valuation). The first are revealed preference techniques, where economists try to parse the portions of real market interactions such as tourism dollars spent or trips to see polar bears at zoos that are reliant on the ecosystem conditions under threat. These are also known as hedonic methods. The alternatives are stated preference techniques, or direct survey methods.

We discuss these with the example of the polar bear, for which a preliminary study using a variety of (imperfect) methods exists, resulting in a very rough average estimate of a willingness to pay by Canadians for polar bear preservation equivalent to $1 \%$ of Canadian household income per year (Ecoresources Consultants, 2011).

\subsubsection{Revealed Preference methods}

As mentioned, revealed preference methods tie market activities to aspects of ecosystems and non-market amenities (see, e.g. Bateman 1993; Bennett, 2011; Hanley et al, 2013). Subsistence hunting, sport hunting, and polar bear viewing in their natural habitat are all activities that can be related to market expenditures.

Polar bear viewing and sport hunting both require direct investments that are made due to the existence of the polar bear. Of course, not all expenditures can be entirely attributed to the bear. For example, if warm winter clothing is purchased for the trip, the portion of the value of the clothing that should be assigned to polar bears is probably not the entire value of the wardrobe, since it can be used for many other cold-weather outings for years. Or consider that you wanted to see polar bears in their native habitat, and that you have a college friend who lives in Churchill, Canada. You plan to visit your friend for a week and spend one day devoted explicitly to finding polar bear viewing. Only $1 / 7$ of your expenses 
should probably be attributed to bear viewing. It is helpful, then, to have a sample of expenditures across activities to try to parse out what is, on average, attributable to the bear and what expenditures might have been due to other reasons. A particular type of revealed preference method, the travel cost method, is most applicable for such cases (see e.g. Barde and Pearce, 2013; Hanley et al, 2013).

Expenditures on hunting licenses are another market item tied to the polar bears' continued existence. One might be tempted to assume that the value of the licenses sold is a good estimate for the hunting value of the bear. While it may be the best proxy available, it is probably not a great estimate however, unless there is price variation in the permits so that a demand curve can be developed (Bennear et al, 2005). This is because such licenses are rarely distributed in an open market system. It may capture the lowest value of the bear to hunters, since the hunt cannot happen without it and hunters who value the hunt less than the license cost will not partake. But it is not likely to capture the upper end, nor is it easily parsed of any other related activities, such as the camaraderie of the hunt or the scenic beauty encountered. Similarly, subsistence hunting values are in one sense measurable by the food expenditures that would have to be made if the hunt were not available. This expenditure might miss many other associated benefits, however, including cultural heritage values and lifestyle satisfaction. One must be careful in applying these valuation methods to truly capture the asset under threat (De Groot et al, 2002). However the biggest disadvantage of revealed preference techniques is that they cannot be used to measure non-use values, or the values to individuals who make no expenditures directly related to the existence of the polar bears. For this, we must turn to survey methods.

\subsubsection{Direct (Survey) Valuation Techniques}

Survey valuation techniques are also known as contingent valuation methods or survey methods (Hanley et al, 2013; Carson, 2012a). As practiced by economists today, they tend to be framed as something called conjoint analysis, in which individuals are asked, in surveys, to choose between scenarios that trade off some financial cost against some non-market amenity. For example, if we wanted to estimate how much polar bears were worth to the average American, who is unlikely ever to travel to see one but might get a "warm glow" from their continued existence nonetheless, or hope to preserve them for their children 
and future generations, for example, we would survey a sample of the population and ask them questions like the following:

Would you choose:

A. A tax of USD 5/year that increased the probability of the continued existence of polar bears for at least 1,000 years from 45 to $55 \%$, or

B. No taxes for polar bear preservation and a continuing probability of $45 \%$ that the bears will survive for the next 1,000 years?

As one surveys different individuals, the cost and the change in probability are varied so that statistical analysis can determine the expected willingness to pay for increases in the probability of survival as a function of the existing probability.

Such methods are valuable because they are the only tools we have to address non-market values. They come under fire, however, for potential biases that are mainly based in concerns that the questions are hypothetical and do not commit the surveyed individuals to make the expenditures in question. For more on this debate, see JEP 2012 symposium (Kling et al, 2012; Carson, 2012b; Hausman, 2012).

\subsection{Using valuations in invasive species management}

For monetary values to affected parties to be most useful to the discussion of invasive species management, the expected changes in the environment that will change the values must be measured at the same scale as the potential intervention. That is, if an invading species threatens the polar bear by reducing the availability of its prey, for example, then the connection must be made between preventing or removing either a biomass measure or a spatial area of an invasive species that is directly translatable to the survivability of the polar bear and its values to society, which may include direct, indirect, and non-use values across a range of interested parties. Again, we see that the economics and the ecology must be tightly interconnected in order to develop the best policies.

In the absence of such knowledge, the Arctic may be one of the cases where erring on the side of precaution outweighs economic considerations. The slow ecological growth conditions and the fragile, unique habitat make it more likely that small perturbations in the system will have large and potentially unanticipated outcomes (Shadwick et al., 2013). 


\subsection{Conclusions}

This chapter seeks to provide an overview of the management of potential invasive species in the Arctic from a bio-economic perspective. To most effectively address the threat of invasive species, the whole series of events from pre-introduction through establishment, spread, and eventual saturation of viable habitat must be considered in a simultaneous integration of human and ecological behaviors. Non-market valuation is an important part of this integration. Appropriate valuation reflecting marginal damages from invasive species not only allows decision-makers at all levels to assess the tradeoffs inherent in the costs and benefits of an invasive species policy option, as well as the costs of failing to act against invasions, but also helps to address questions of why, where and how invasive species should be combatted by allowing comparisons in outcomes across policy options.

Even with the natural barriers that the Arctic climate has historically provided against invasions, marine invasive species in the Arctic have already been both intentionally (e.g. Red King Crab in Russia) and unintentionally (e.g. Snow Crab in Norway) established and identified. Countless others may already be underway, and certainly the increased human use of Arctic waters will increase the probability of new invasions. Policy options are the most flexible before invasion; the potential to minimize damages from invasions only shrinks as time passes. Thus the faster good preventative policy and early detection monitoring programs can be agreed upon and established amongst various Arctic states, the higher the expected net gain to all parties.

\subsection{Works Cited}

ACIA (2004). Impacts of a Warming Arctic: Arctic Climate Impact Assessment. ACIA Overview report. Cambridge University Press. pp. 140.

Atkinson, S. M., Mourato, S., \& Pearce, D. (2006). Cost-Benefit Analysis and the Environment.

Barde, J. P., \& Pearce, D. W. (Eds.). (2013). Valuing the environment: six case studies. Routledge.

Bateman, I. J. (1993). Valuation of the environment, methods and techniques: revealed preference methods. Sustainable Environmental Economics and Management: Principles and Practice. Belhaven: London.

Bax, N.; Carlton, J. T.; Mathews-Amos, A.; Haedrich, R. L.; Howarth, F. G.; Purcell, J. E.; Rieser, A.; Gray, A. (2001). The Control of Biological Invasions in the World's Oceans. Conservation Biology 15(5):1234-1246. DOI: 10.1046/j.15231739.2001.99487.x. 
Beattie, O. and J. Geiger (1987). Frozen in Time: The Fate of the Franklin Expedition. London: Bloomsbury.

Bennear, L. S., Stavins, R. N., \& Wagner, A. F. (2005). Using revealed preferences to infer environmental benefits: Evidence from recreational fishing licenses. Journal of Regulatory Economics 28(2), 157-179.

Bennett, J. (Ed.). (2011).The International Handbook on Non-Market Environmental Valuation. Edward Elgar Publishing.

Bull, J.B. (2011). Fridtjof Nansen: A Book for the Young. Trans. M.R. Barnard. Project Gutenberg ebook.

Burgiel, S., Foote, G., Orellana, M., \& Perrault, A. (2006). Invasive alien species and trade: integrating prevention measures and international trade rules. The Center for International Environmental Law and Defenders of Wildlife, Washington, DC.Burnett, K.; D’Evelyn, S.; Kaiser, B.; Nantamanasikam, P., and J. Roumasset. Beyond the Lamppost: Optimal Prevention and Control of the Brown Treesnake in Hawaii (2008), Ecological Economics, 67, pp. 66-74.

Burnett, K.; Kaiser, B.; and J. Roumasset (2007). Economic Lessons from Control Efforts for an Invasive Species: Miconia calvescens in Hawaii Journal of Forest Economics 13(2-3):151-167

Burnett, K., Pongkijvorasin, S., and J. Roumasset (2012). Species Invasion as Cata strophe: The Case of the Brown Tree Snake. Environmental and Resource Economics 51(2): 241-254.

Carson, R. (2012a). Contingent valuation: a comprehensive bibliography and history. Edward Elgar Publishing.

Carson, R. T. (2012b). Contingent valuation: a practical alternative when prices aren't available. The Journal of Economic Perspectives, 27-42.

De Groot, R. S., Wilson, M. A., \& Boumans, R. M. (2002). A typology for the classification, description and valuation of ecosystem functions, goods and services. Ecological economics 41(3), 393-408.

Ecoressources Consultants (2011). Evidence of the Socio-Economic Importance of Polar Bears for Canada. Report prepared for Environment Canada.

Economist, The, (2012). The Vanishing North, Jun $16^{\text {th }} 2012$. Available online at http://www.economist.com/node/21556921

Falk-Petersen, J.; Renaud, P.; and Anisimova, N. (2011). Establishment and ecosystem effects of the alien invasive red king crab (Paralithodes kamtschaticus) in the Barents sea - a review. ICES Journal of Marine Science 68(3):479-488.

Freeman, A. M. (2003). The measurement of environmental and resource values: theory and methods. Resources for the Future.

Frid, L; Knowler, D.; Myers, J.H.; Scott, L.; Murray, C. 2013. A multi-scale framework for evaluating the benefits and costs of alternative management strategies against invasive plants. Journal of Environmental Planning and Management 56(3): 412-434.

Garrod, G., \& Willis, K. G. (1999). Economic valuation of the environment: methods and case studies (pp. 132-133). Cheltenham: Edward Elgar.

Hanley, N., Shogren, J., \& White, B. (2013). Introduction to environmental economics. Oxford University Press.

Hausman, J. (2012). Contingent valuation: from dubious to hopeless. The Journal of Economic Perspectives 26(4), 43-56.

Inglis, G., Floerl, O., \& Woods, C. (2012). Scenarios of Vessel Biofouling Risk and their Management.MAF Research Project RFP11832. Ministry of Agriculture and Forestry, Wellington, 41-93. 
Johnston, E.L.; Piola, R.F.; and G.F. Clark. (2009). The Role of Propagule Pressure in Invasion Success. Biological Invasions in Marine Ecosystems: 133-151.

Jørgensen, L.L. and E.M. Nilssen (2011). The Invasive History, Impact, and Management of the Red King Crab Paralithodes kamtcshaticus off the coast of Norway. In the Wrong Place - Alien Marine Crustaceans: Distribution, Biology and Impacts. Eds. Galil, B.S.; Clark, P.F. and J.T. Carlton. P. 511-526

Kaiser, B. (2006). Economic Impacts of Non-indigenous Species: Miconia and the Hawaiian Economy, Euphytica 148(1-2): 135-150.

Kaiser, B. and K. Burnett (2010). Spatial economic analysis of early detection and rapid response strategies for an invasive species. Resource Energy Econ. doi: 10.1016/j.reseneeco.2010.04.007

Katz, C. and A. Kirby (1991). In the nature of things: the environment and everyday life, Transactions of the Institute of British Geographers 15(3): 259-271.

Kirch, P.V. (1985). Feathered Gods and Fishhooks: An Introduction to Hawaiian Archaeology and Prehistory. Honolulu: University of Hawaii Press.

Kling, C. L., Phaneuf, D. J., \& Zhao, J. (2012). From Exxon to BP: Has some number become better than no number? The Journal of Economic Perspectives, 3-26.

Kraus, F. (2009). Alien Reptiles and Amphibians: A Scientific Compendium and Analysis. Springer-Verlag.

Orlov, Y.I. and Ivanov, B.G. (1978). On the Introduction of the Kamchatka King Crab Paralithodes camtschatica (Decapoda: Anomura: Lithodidae) into the Barents Sea. Marine Biology 48(4): 373-375.

Reaser, J.K; Meyerson, L.A.; Cronk, Q.; De Poorter, M.; Eldrege, L.G.; Green, E.; Kairo, M.; Latasi, P.; Mack, R.N.; Mauremootoo, J.; O’Dowd, D.; Orapa, W.; Sastroutomo, S.; Saunders, A.; Shine, C.; Thrainsson, S. and L. Vaiutu (2007). Ecological and socioeconomic impacts of invasive alien species in island ecosystems. Environmental Conservation 34, pp 98-111. doi:10.1017/S0376892907003815.

Ruiz, G. M.; Carlton, J.T., eds. 2003. Invasive Species: Vectors and Management Strategies. Washington, DC: Island Press.

Shadwick, E. H.; Trull, T. W.; Thomas, H.; Gibson, J. A. E. (2013. Vulnerability of Polar Oceans to Anthropogenic Acidification: Comparison of Arctic and Antarctic Seasonal Cycles. Scientific Reports 3 (Article \#2339) http://dx.doi.org/10.1038/srep02339

Simberloff, D. (2009). The Role of Propagule Pressure in Biological Invasions. Annual Review of Ecology, Evolution, and Systematics 40:81-101.

Strayer, D. (2009). Twenty years of zebra mussels: lessons from the mollusk that made headlines, Frontiers in Ecology and the Environment 7(3).

Stewart, J. and E. Tallaksen (2013). King crab prices keep dropping on suspected IUU fishing. Undercurrent News, May 17, 2013. URL: http://www.undercurrentnews.com/ 2013/05/17/king-crab-prices-keep-dropping-on-suspected-iuu-fishing/

Wittenberg, R., \& Cock, M. J. (Eds.). (2001).Invasive alien species: a toolkit of best prevention and management practices. CABI. 



\section{Sammendrag}

Arktiske marine økosystemer er blandt de mest produktive og mest sårbare i verden, både fra et økonomisk og økologisk perspektiv på grund af voksende tilgængelighed. Sårbarhed af arktiske marine økosystemer og deres placering en udfordring for forvaltningen og etableringen af en balanceret politik for at beskytte dem. I erkendelse af disse udfordringer og betydningen af at behandle nogle af de vigtigste trusler, præsenterer dette særnummer af TemaNord bidrag fra en workshop sponsoreret af Nordregio, Syddansk Universitet og NOS-HS. Workshoppen blev afholdt i Esbjerg i oktober 2013, hvor en gruppe af tværfaglige videnskabelige og økonomiske eksperter deltog. Ttilen for workshoppen var: "Marine Invasive Species in the Arctic: Management Issues" Deltagerne i workshoppen kom fra akademiske, statslige og videnskabelige institutioner i Danmark og Færøerne, Sverige, Norge, Finland, Island, Canada og USA. 



\section{Appendix}

13.1 Program, Marine Invasive Species in the Arctic: Management Issues, Oct 24-26, 2013

\section{Primary Organizers}

- Brooks A. Kaiser.

- Linda Fernandez.

- Niels Vestergaard.

\section{Keynote speakers}

- Mike Gill, Vice-Chair, Group on Earth Observations - Biodiversity Observations Network. Special Advisor, Circumpolar Biodiversity Monitoring Program. (Whitehorse, CA).

- Linda Fernandez, Assoc. Professor, Virginia Commonwealth University (Richmond, VA, USA).

- Whitman Miller, Research Scientist, Smithsonian Environmental Research Center (Edgewater, MD, USA).

- Brooks Kaiser, Professor, University of Southern Denmark, (Esbjerg, DK).

\section{Location}

DanHostel, Esbjerg, DK. 


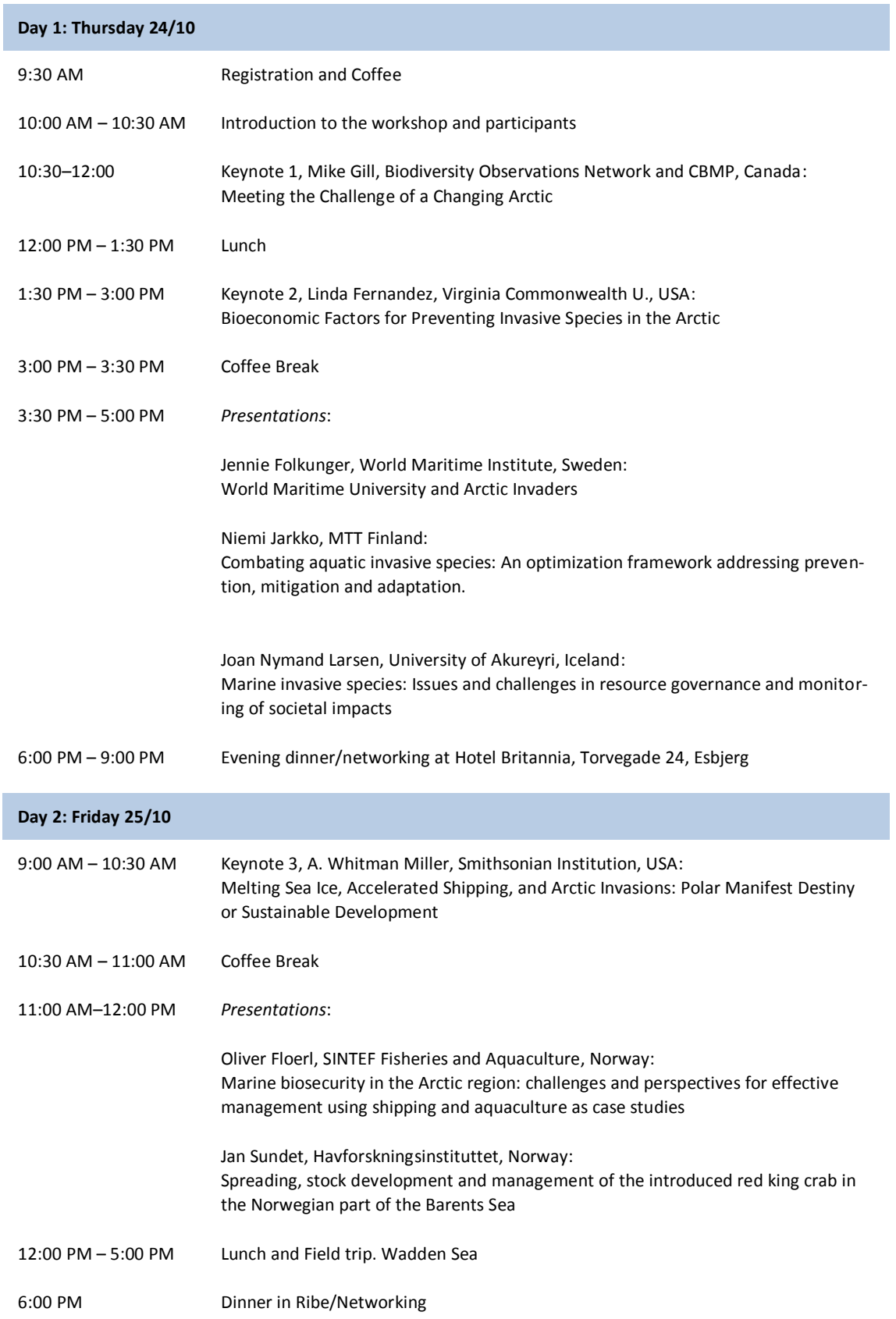


Day 3: Sat $26 / 10$

9:00 AM - 10:30 AM

Presentations:

Jan Sundet, Havforskningsinstituttet, Norway:

The invasive snow crab (Chionoecetes opilio), an expanding player in the Barents

Sea ecosystem.

Jon Olaf Olaussen, Trondheim Business School, Norway:

Adaptive harvest under invasive induced mortality

Gudrun Thorarinsdóttir, Marine Research Institute, Iceland:

Marine invasive species in the Arctic: Icelandic Perspective

10:30 AM -11:00 AM Coffee Break

11:00 AM - 12:00 AM Presentation:

Hans Ellefsen, Faroese Ministry of Fisheries, Faroe Islands:

Entry deterrence in the mackerel fishery

Rasmus Gjedss $\varnothing$ Bertelsen, Aalborg University, Denmark:

The International and Transnational Relations of Marine Resources in the North

Atlantic and Arctic Ocean from the Pecheurs d'Islande to Asia's Interest in the Arctic

12:00 AM - 1:00 PM L Lunch

1:00 PM - 2:00 PM Keynote 4 with discussion, Brooks Kaiser, SDU, DK:

Invasive Species Management Strategies: Adapting in the Arctic

2:00 PM - 3:00 PM

Strategy discussions for targeted research collaborations

3:00 PM - 3.30 PM

Coffee Break

3:30 PM - 5:30 PM

Roundtable discussions.

Nordic challenges and strategies for invasive species management in the Arctic 


\subsection{List of participants}

\begin{tabular}{|c|c|c|c|}
\hline & Name & Place of Employment & E-mail \\
\hline 1 & Brooks Kaiser & University of Southern Denmark & baka@sam.sdu.dk \\
\hline 2 & Niels Vestergaard & University of Southern Denmark & nv@sam.sdu.dk \\
\hline 3 & Linda M. Fernandez & Virginia Commonwealth University, USA & Imfernandez@vcu.edu \\
\hline 4 & Whitmann Miller & $\begin{array}{l}\text { Smithsonian Environmental Research Center, } \\
\text { USA }\end{array}$ & millerw@si.edu \\
\hline 5 & Mike Gill & $\begin{array}{l}\text { Environment Canada and Circumpolar Biodi- } \\
\text { versity Monitoring Group }\end{array}$ & Mike.Gill@ec.gc.ca \\
\hline 6 & Oliver Floerl & SINTEF Fisheries and Aquaculture, Norway & oliver.floerl@sintef.no \\
\hline 7 & Jennie Folkunger & WMU, World Maritime University, Sweden & jf@wmu.se \\
\hline 8 & Gudrun G. Thorarinsdóttir & Marine Research Institute, Iceland & gutho@hafro.is \\
\hline 9 & Jan H. Sundet & Havforskningsinstituttet, Norway & jan.h.sundet@imr.no \\
\hline 10 & Joan Nymand Larsen & University of Akureyri, Iceland & jnl@unak.is \\
\hline 11 & Jon Olaf Olaussen & Trondheim Business School, Norway & jon.o.olaussen@hist.no \\
\hline 12 & Hans Ellefsen & Faroese Ministry of Fisheries, Faroe Islands & Hans.Ellefsen@fisk.fo \\
\hline 13 & Niemi Jarkko & $\begin{array}{l}\text { MTT Agrifood Research Finland, Economic } \\
\text { Research, Finland }\end{array}$ & jarkko.niemi@mtt.fi \\
\hline 14 & Lars Ravn-Johnsen & University of Southern Denmark & Irj@sam.sdu.dk \\
\hline 15 & Rasmus G. Bertelsen & Aalborg University, Denmark & rasmus@cgs.aau.dk \\
\hline 16 & Barbara Hutniczak & University of Southern Denmark & bhu@sam.sdu.dk \\
\hline 17 & Stefan Borsky & University of Southern Denmark & stbo@sam.sdu.dk \\
\hline 18 & Angela Münch & University of Southern Denmark & amuench@sam.sdu.dk \\
\hline 19 & Masako Ikefuji & University of Southern Denmark & ikefuji@sam.sdu.dk \\
\hline
\end{tabular}


Nordic Council of Ministers

Ved Stranden 18

DK-1061 Copenhagen K

www.norden.org

\section{Marine invasive species in the Arctic}

Arctic marine ecosystems are among the most productive and most vulnerable in the world, both from an economic and ecological perspective of growing accessibility. The complexity of Arctic marine ecosystems and their location poses challenges for management, valuation, and the establishment of sound policy to protect them. This special issue of Temanord presents papers from a workshop devoted to this topic. In October 2013, a group of multidisciplinary experts on marine invasive species and the Arctic came together in Esbjerg, DK for a two-day workshop titled: "Marine Invasive Species in the Arctic: Management Issues." Attendees of the workshop came from academic, governmental and scientific institutions in Denmark and the Faroe Islands, Sweden, Norway, Finland, Iceland, Canada, and the United States. This volume presents papers based on the presentations of the workshop speakers 